\title{
Evaluation of Suitability of Selected Set of Department of Defense Military Bases and Department of Energy Facilities for Siting a Small Modular Reactor
}

\section{March 2013}

Prepared by

W. P. Poore

R. J. Belles

G. T. Mays

O. A. Omitaomu

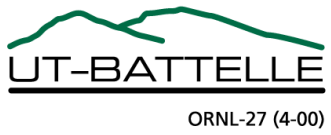




\section{DOCUMENT AVAILABILITY}

Reports produced after January 1, 1996, are generally available free via the US Department of Energy (DOE) Information Bridge.

Web site http://www.osti.gov/bridge

Reports produced before January 1, 1996, may be purchased by members of the public from the following source.

National Technical Information Service

5285 Port Royal Road

Springfield, VA 22161

Telephone 703-605-6000 (1-800-553-6847)

TDD 703-487-4639

Fax 703-605-6900

E-mail info@ntis.gov

Web site http://www.ntis.gov/support/ordernowabout.htm

Reports are available to DOE employees, DOE contractors, Energy Technology Data Exchange (ETDE) representatives, and International Nuclear Information System (INIS) representatives from the following source.

Office of Scientific and Technical Information

P.O. Box 62

Oak Ridge, TN 37831

Telephone 865-576-8401

Fax 865-576-5728

E-mail reports@osti.gov

Web site http://www.osti.gov/contact.html

This report was prepared as an account of work sponsored by an agency of the United States Government. Neither the United States Government nor any agency thereof, nor any of their employees, makes any warranty, express or implied, or assumes any legal liability or responsibility for the accuracy, completeness, or usefulness of any information, apparatus, product, or process disclosed, or represents that its use would not infringe privately owned rights. Reference herein to any specific commercial product, process, or service by trade name, trademark, manufacturer, or otherwise, does not necessarily constitute or imply its endorsement, recommendation, or favoring by the United States Government or any agency thereof. The views and opinions of authors expressed herein do not necessarily state or reflect those of the United States Government or any agency thereof. 
Reactor and Nuclear Systems Division Computational Sciences and Engineering Division

\title{
EVALUATION OF SUITABILITY OF SELECTED SET OF DEPARTMENT OF DEFENSE MILITARY BASES AND DEPARTMENT OF ENERGY FACILITIES FOR SITING A SMALL MODULAR REACTOR
}

\author{
W. P. Poore \\ R. J. Belles \\ G. T. Mays \\ O. A. Omitaomu
}

Date Published: March 2013

Prepared for

US Department of Energy, Office of Nuclear Energy

Prepared by

OAK RIDGE NATIONAL LABORATORY

Oak Ridge, Tennessee 37831-6283

managed by

UT-BATTELLE, LLC

for the

US DEPARTMENT OF ENERGY

under contract DE-AC05-00OR22725 



\section{CONTENTS}

Page

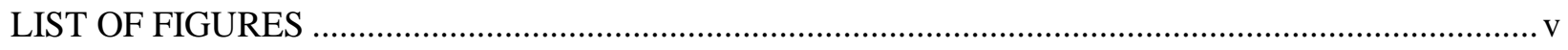

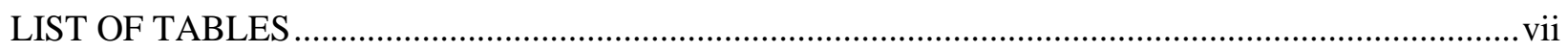

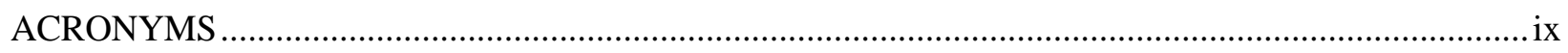

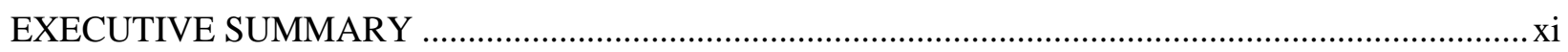

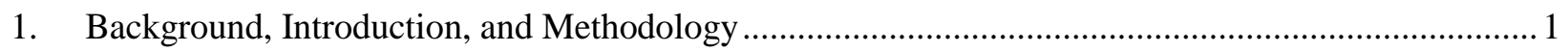

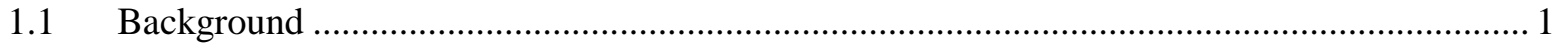

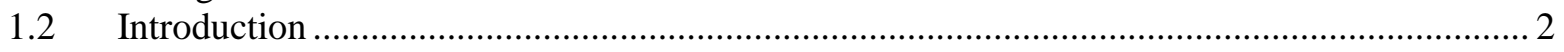

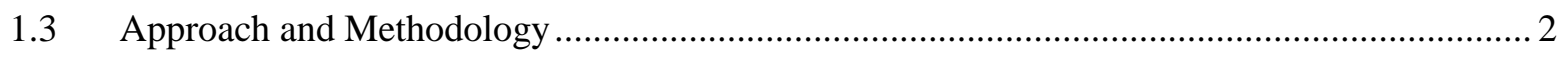

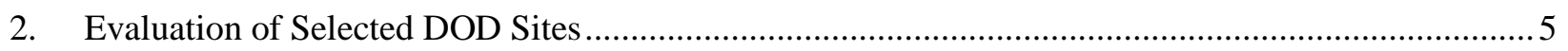

2.1 Review of Nominal SMR Site Selection and Evaluation Criteria....................................... 5

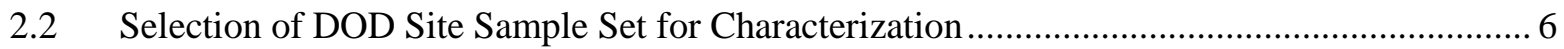

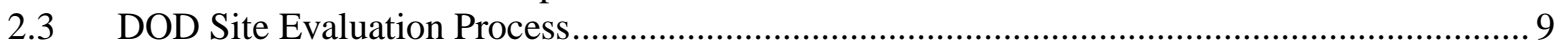

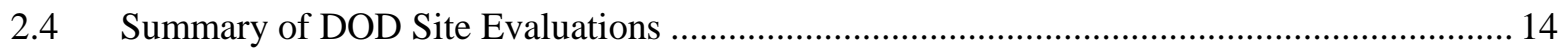

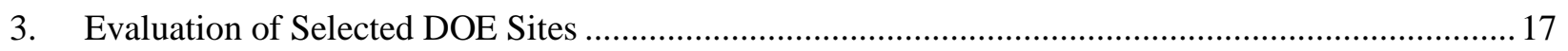

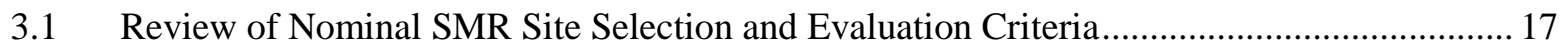

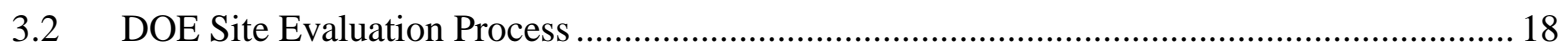

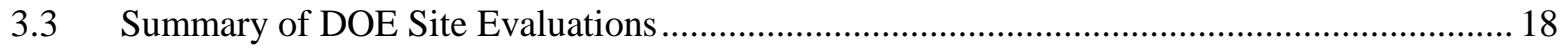

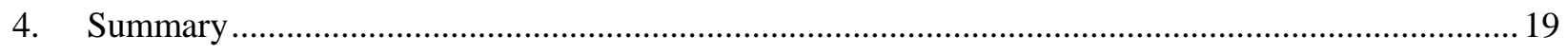

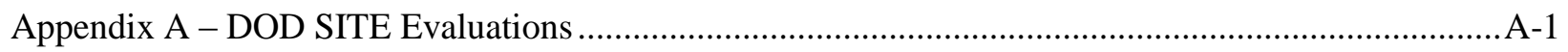

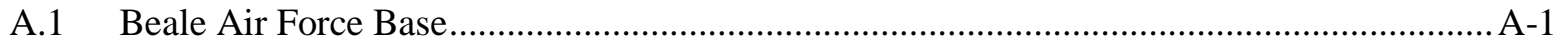

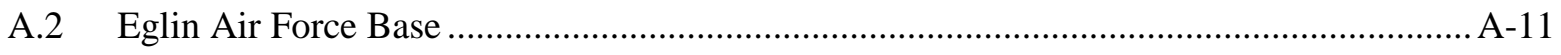

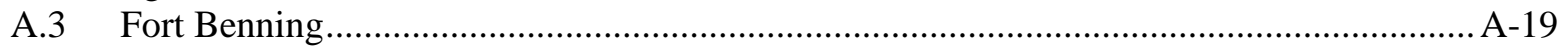

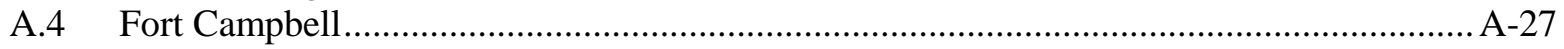

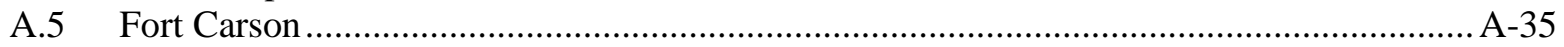

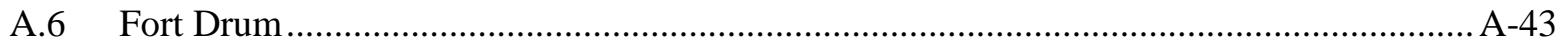

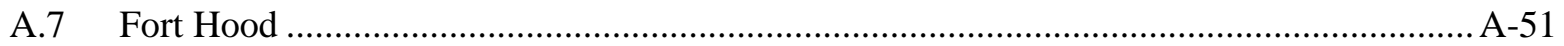

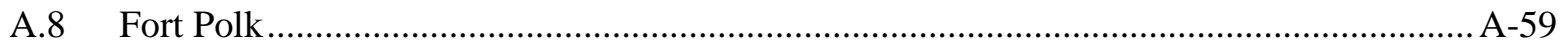

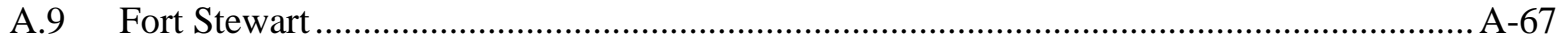

A.10 Naval Surface Warfare Center - Crane......................................................................... A-75

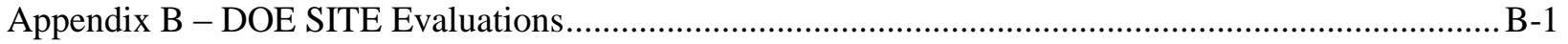

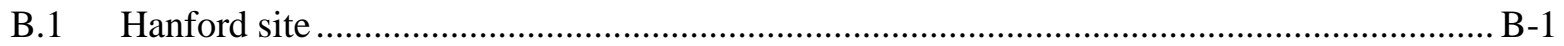

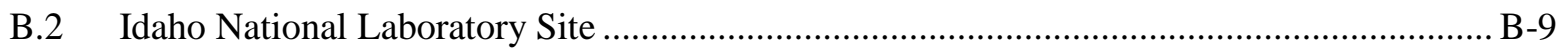

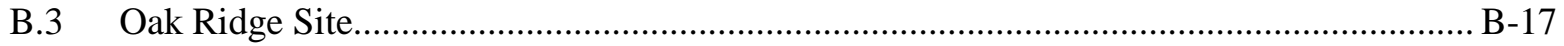

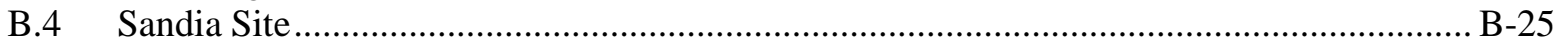

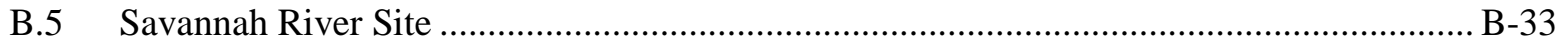





\section{LIST OF FIGURES}

Figure

ES-1. All DOD and Coast Guard locations relative to SMR aggregate map ...................................ii

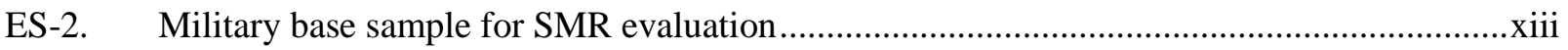

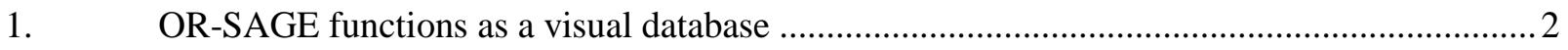

2. Nominal, bounding SMR composite map detailing siting challenges................................... 6

3. All US military base locations relative to SMR aggregate map........................................... 7

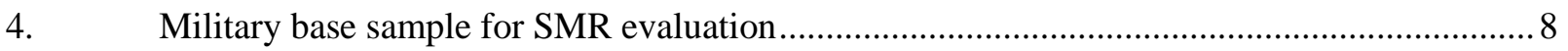

5. Sample military base location map (Fort Hood, Texas) ...................................................... 9

6. Sample satellite view of DOD site (Fort Hood, Texas) ....................................................... 11

7. Sample DOD site composite map (Fort Hood, Texas) ......................................................... 13

8. Sample individual SSEC criterion map (Fort Hood, Texas) ................................................. 14

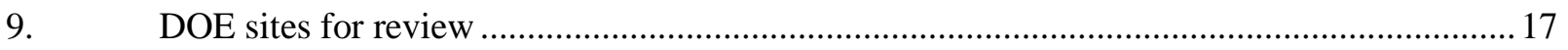

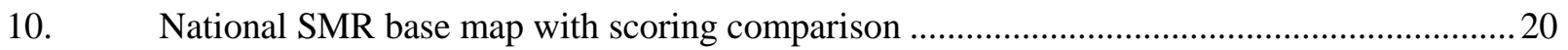

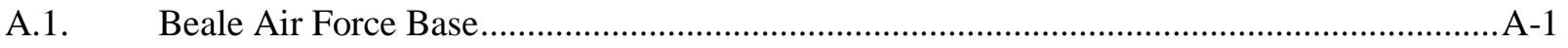

A.2. Satellite view of Beale Air Force Base area ......................................................................

A.3. Beale Air Force Base composite map ..........................................................................

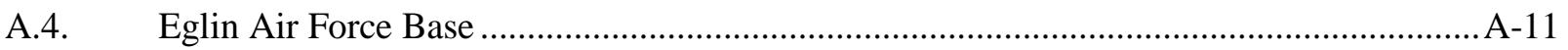

A.5. Satellite view of Eglin Air Force Base area ................................................................A-13

A.6. Eglin Air Force Base composite map ............................................................................. A-15

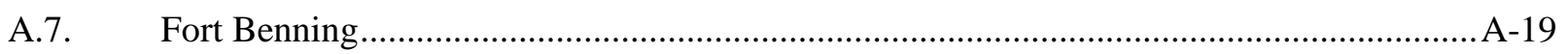

A.8. Satellite view of Fort Benning area ........................................................................ A-21

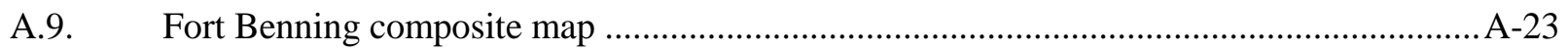

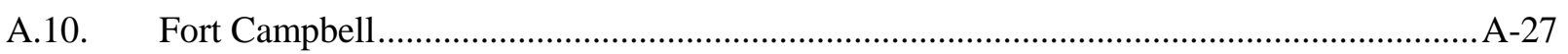

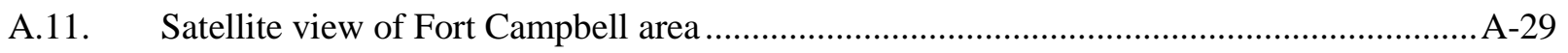

A.12. Fort Campbell composite map ................................................................................. A-31

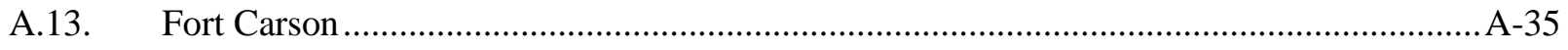

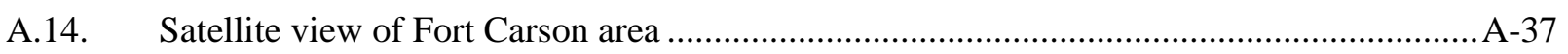

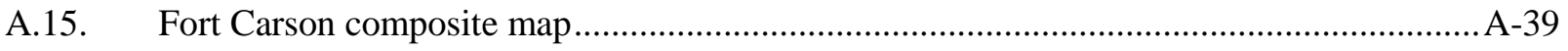

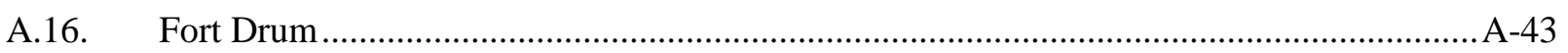

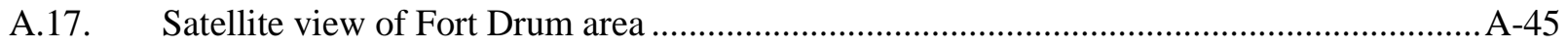

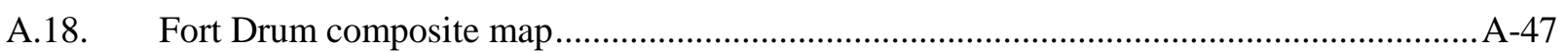

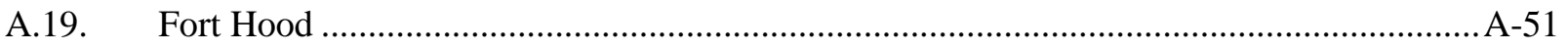

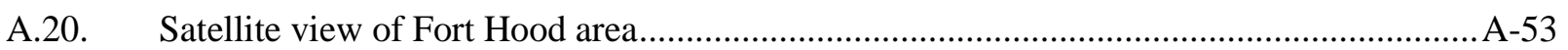

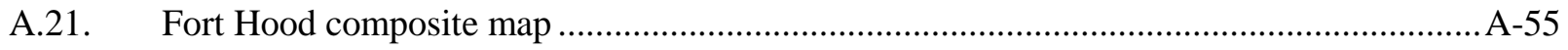

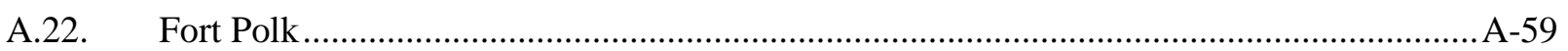

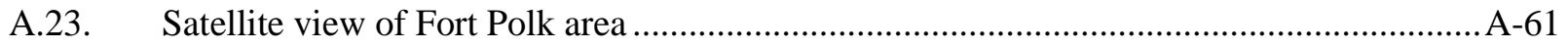

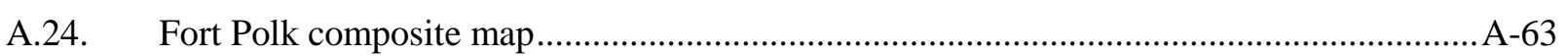

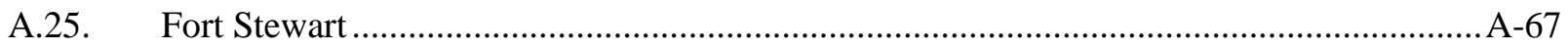

A.26. Satellite view of Fort Stewart area ….......................................................................... A-69 


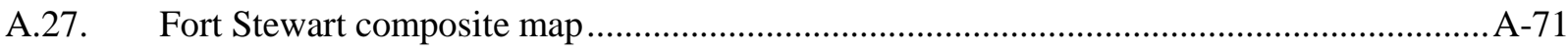

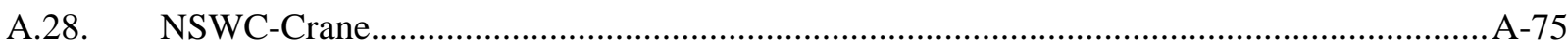

A.29. Satellite view of NSWC-Crane area.........................................................................

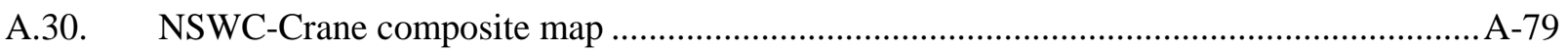

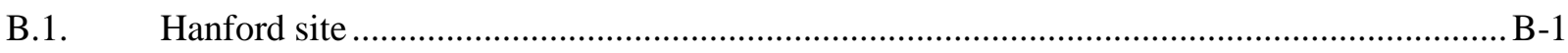

B.2. Satellite view of Hanford site area ......................................................................... B-3

B.3. Hanford site composite map ….................................................................................

B.4. Idaho National Laboratory site .................................................................................... B-9

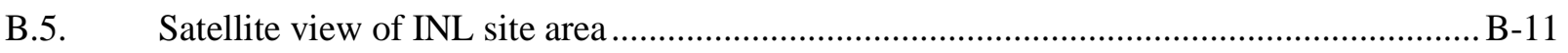

B.6. Idaho National Laboratory site composite map........................................................... B-13

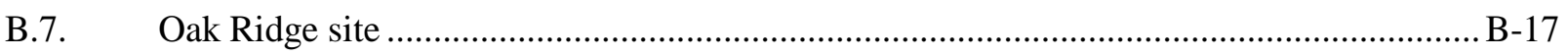

B.8. Satellite view of Oak Ridge site area ........................................................................... B-19

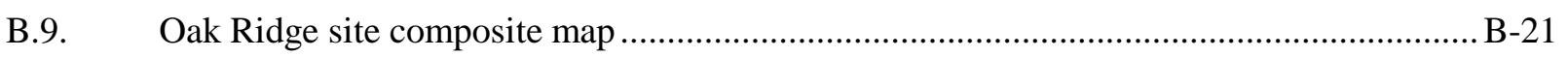

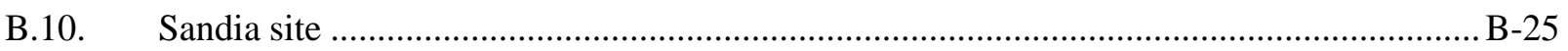

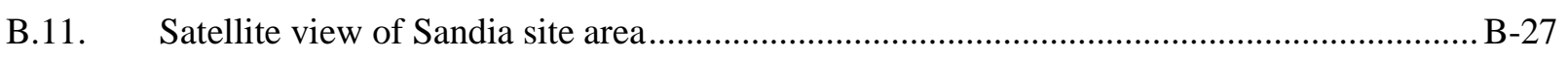

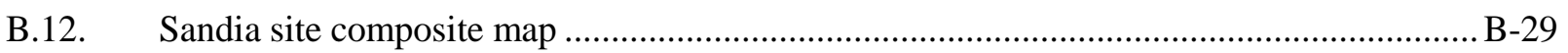

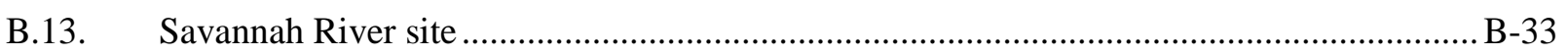

B.14. Satellite view of Savannah River site area .................................................................. B-35

B.15. Savannah River site composite map........................................................................ B-37 


\section{LIST OF TABLES}

Table

Page

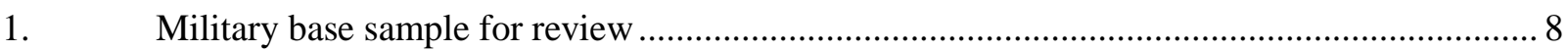

2. Sample DOD site statistical summary (Fort Hood, Texas) ............................................... 10

3. Sample DOD site criteria summary (Fort Hood, Texas) ..................................................... 12

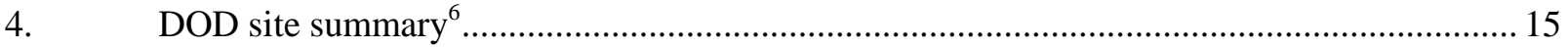

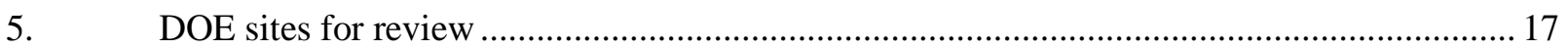

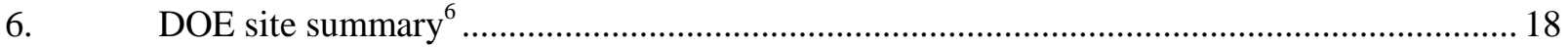

A.1. Beale Air Force Base site statistics ............................................................................ A-2

A.2. Beale Air Force Base siting criteria summary ….............................................................

A.3. Eglin Air Force Base site statistics .......................................................................... A-12

A.4. Eglin Air Force Base siting criteria summary …......................................................... A-14

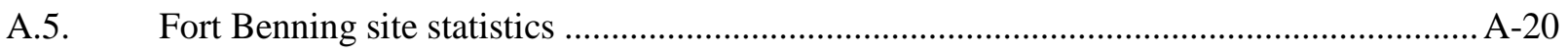

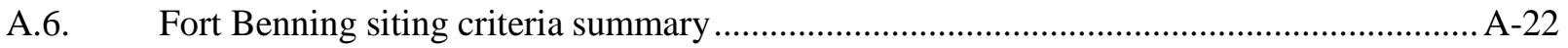

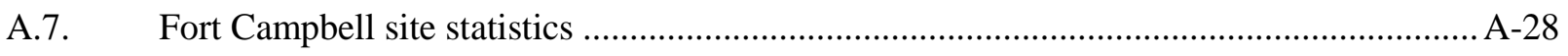

A.8. Fort Campbell siting criteria summary …................................................................ A-30

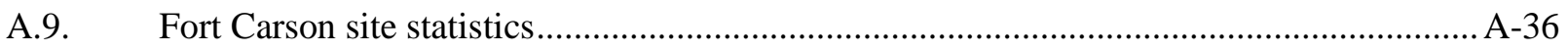

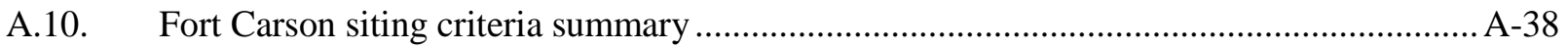

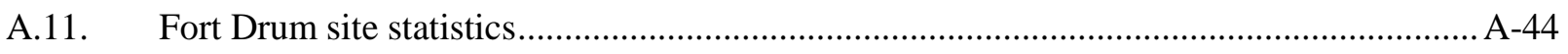

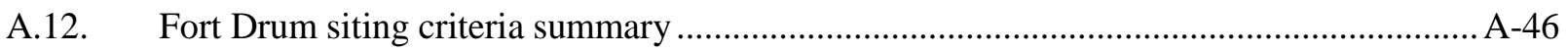

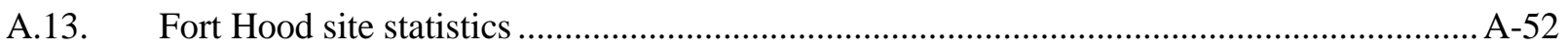

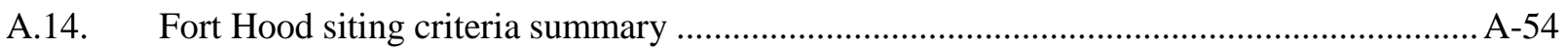

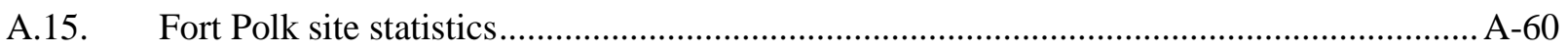

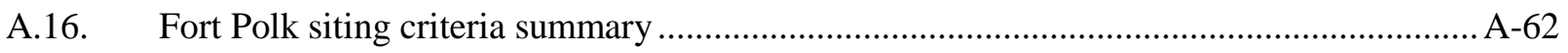

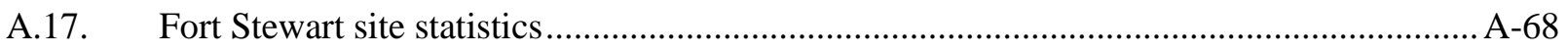

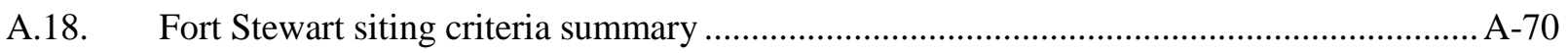

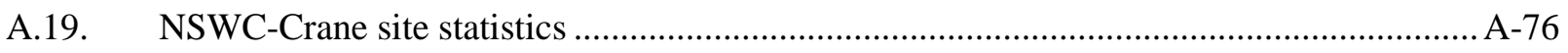

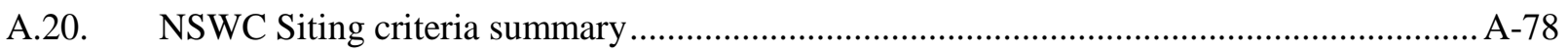

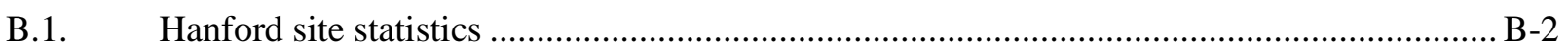

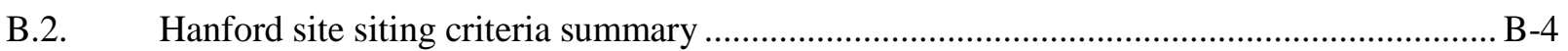

B.3. Idaho National Laboratory Site Statistics .............................................................. B-10

B.4. Idaho National Laboratory site siting criteria summary ............................................... B-12

B.5. Oak Ridge Site statistics..................................................................................... B-18

B.6. Oak Ridge site siting criteria summary ...................................................................... B-20

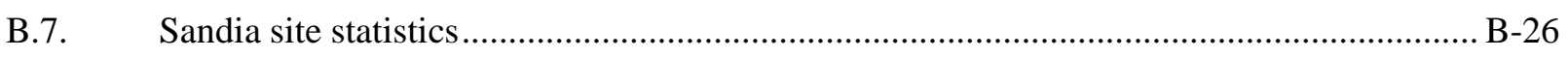

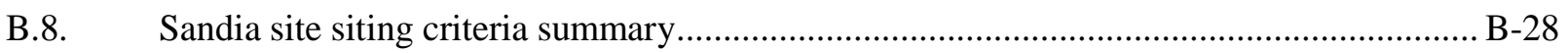

B.9. Savannah River Site statistics............................................................................... B-34

B.10. Savannah River site siting criteria summary ............................................................. B-36 



\section{ACRONYMS}

\begin{tabular}{ll} 
ASOS & Air Support Operation Squadron \\
BRAC & Base Realignment and Closure \\
DOD & US Department of Defense \\
DOE & US Department of Energy \\
EIA & DOE Energy Information Administration \\
EPA & US Environmental Protection Agency \\
EPRI & Electric Power Research Institute \\
ESP & early site permit \\
ETTP & East Tennessee Technology Park \\
GIS & geographic information systems \\
gpm & gallons per minute \\
GW(e) & gigawatt electrical \\
HSIP & Homeland Security Infrastructure Protection \\
INL & Idaho National Laboratory \\
iPWR & integral pressurized-water reactor \\
JRTS & Joint Readiness Training Center \\
LANL & Los Alamos National Laboratory \\
LWR & light-water reactor \\
MW(e) & megawatt electrical \\
NE & (DOE) Office of Nuclear Energy \\
NNSA & National Nuclear Security Administration \\
NRC & US Nuclear Regulatory Commission \\
NSWC & Naval Surface Warfare Center \\
ORNL & Oak Ridge National Laboratory \\
OR-SAGE & Oak Ridge Siting Analysis for Power Generation Expansion \\
PNNL & Pacific Northwest National Laboratory \\
PWR & sressurized-water reactor \\
SMR & Sandil modular reactor \\
SNL & safe shutdown earthquake \\
SSE & Site selection and evaluation criteria \\
SSEC & SRS \\
USGS & Savarvey \\
\hline
\end{tabular}





\section{EXECUTIVE SUMMARY}

\section{Background}

Beginning in late 2008, Oak Ridge National Laboratory (ORNL) responded to ongoing internal and external studies addressing key questions related to our national electrical energy supply. This effort has led to the development and refinement of Oak Ridge $\underline{\text { Siting }}$ Analysis for Power Generation Expansion (OR-SAGE), a tool to support power plant siting evaluations. The objective in developing OR-SAGE was to use industry-accepted approaches and/or develop appropriate criteria for screening sites and employ an array of geographic information systems (GIS) data sources at ORNL to identify candidate areas for a power generation technology application. The basic premise requires the development of exclusionary, avoidance, and suitability criteria for evaluating sites for a given siting application such as siting small modular reactors (SMRs). For specific applications of the tool, it is necessary to develop site selection and evaluation criteria (SSEC) that encompass a number of key benchmarks that essentially form the site environmental characterization for that application. These SSEC might include population density, seismic activity, proximity to water sources, proximity to hazardous facilities, avoidance of protected lands and floodplains, susceptibility to landslide hazards, and others.

The OR-SAGE tool is essentially a dynamic visualization database. The SSEC are the fields of the database, and the GIS data for a given variable represent the values against which searches are performed. The evaluation process divides the contiguous United States into 100 by $100 \mathrm{~m}$ (1 hectare) squares (cells), applying successive SMR-appropriate SSEC to each cell. There are just under 700 million cells representing the contiguous United States. If a cell meets the requirements of each SMR criterion, the cell is included as a candidate to be integrated in the possible siting of an SMR. Some SSEC parameters preclude siting a facility because of an environmental, regulatory, or land-use constraint. Other SSEC assist in identifying less favorable areas, such as proximity to hazardous operations. All of the selected SSEC tend to recommend against sites; that is, they tend to identify areas in which there are challenges to using the site for the purpose of interest. In the first phase of this SMR site-screening study ${ }^{1}$ supporting US Department of Energy (DOE) Office of Nuclear Energy (NE), the ORNL OR-SAGE siting tool was enhanced to focus on issues related specifically to the siting of SMRs.

This report summarizes the second phase of the approach that ORNL developed for screening a sample set of US Department of Defense (DOD) military base sites and DOE sites for possible powering with an SMR; the methodology employed, including spatial modeling; and initial results for several sample sites. The objective in conducting this type of siting evaluation is demonstrate the capability to characterize specific DOD and DOE sites to identify any particular issues associated with powering the sites with an SMR; it is not intended to be a definitive assessment per se as to the absolute suitability of any particular site.

\section{Sample Set Selection and Evaluation}

There are approximately 700 DOD military bases or Coast Guard Stations in the United States as shown in Fig. ES-1. In addition, there are approximately 40 DOE sites in the United States. Many of the sites have national interests and national security missions, which are a good match with reliable, dependable, compact, and secure on-site, non-carbon-emitting SMR power generation. Site power requirements for the DOD sites can be considerable, given power requirements for supporting base missions and base infrastructure that often include tens of thousands of on-site workers and site residents. DOE sites often have large power requirements for power-intensive missions, such as those associated with high performance computing centers or other national missions.

\footnotetext{
${ }^{1}$ R. J. Belles, G. T. Mays, O. A. Omitaomu, W. P. Poore, Updated Application of Spatial Data Modeling and Geographical Information Systems (GIS) for Identification of Potential Siting Options for Small Modular Reactors, ORNL/TM-2012/403, September 2012.
} 


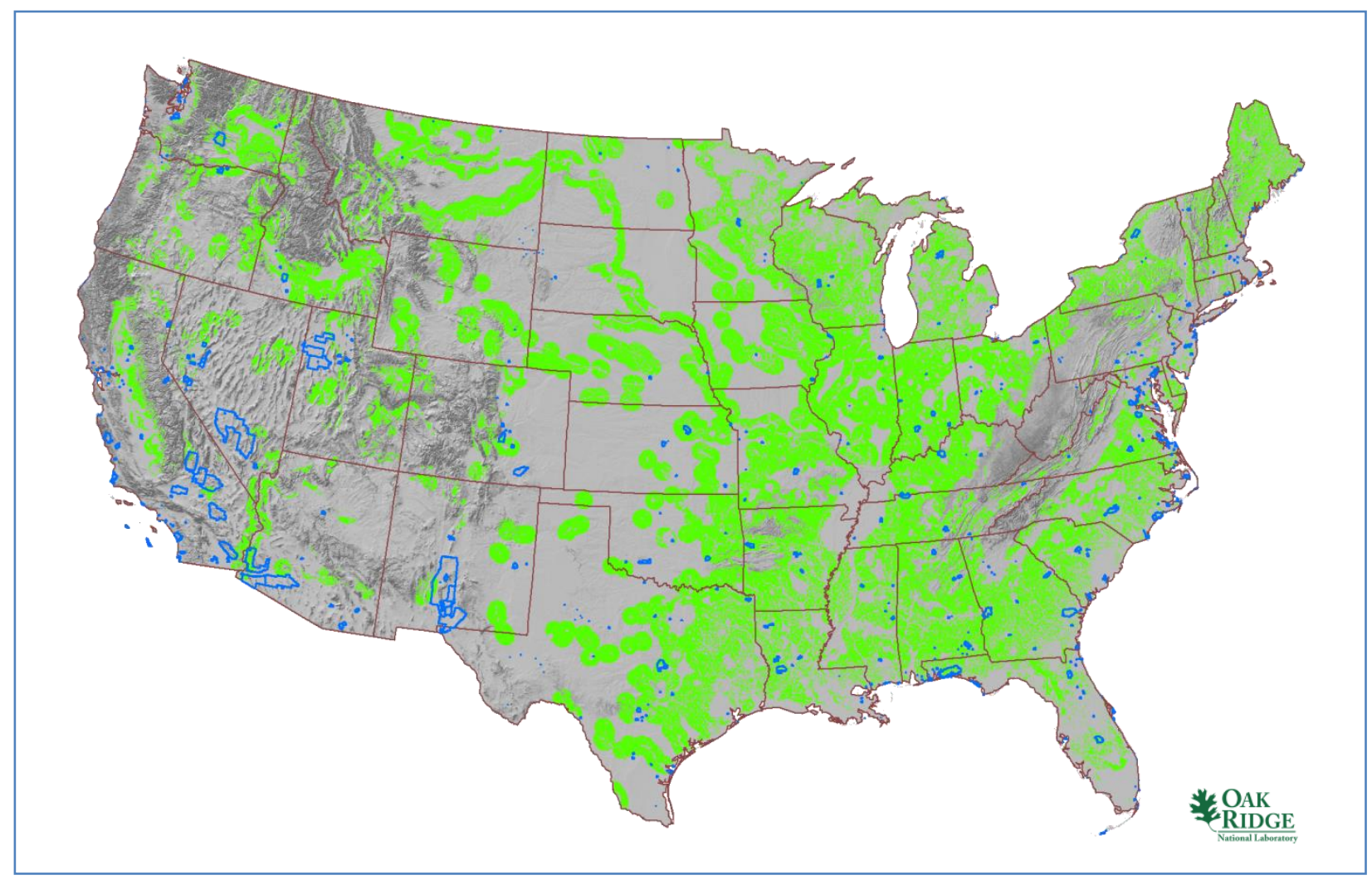

Fig. ES-1. All DOD and Coast Guard locations relative to SMR aggregate map.

It was assumed that only larger DOD sites would be candidates for hosting an SMR facility. Therefore, only bases with area greater than 1000 acres were initially considered. At this minimum area, a 50-acre SMR site area would occupy 5\% of a 1000-acre base. Engineering judgment suggested that any higher percentage of the base land would take away from the base mission. In addition, a larger base size should provide space to locate an SMR away from the immediate proximity of existing base facilities and training areas. There are 350 sites that include more than 1000 acres. A further refinement indicates that there are 135 sites that include more than 10,000 acres, which would offer even greater flexibility in siting an SMR remotely.

Only those military and Coast Guard bases that included land with no siting issues, a single siting issue, or within 5 miles of land that has no siting issues were considered for further evaluation. Essentially all DOD or Coast Guard sites that had two or more siting issues were not included for this initial round of characterization unless the site included space within 5 miles of land with no siting issues. The latter consideration was made in the event that nearby land could be offered as an alternative for an SMR site. Approximately, 170 military bases passed this intermediate screening process.

Ten DOD sites were selected for review to determine if there appeared to be a good likelihood of siting a base-supporting SMR. Large sites were looked at preferentially. The selected sites are located as shown in Fig. ES-2, and a list of the sample set of DOD sites is provided in the body of the report in Table 1. Five larger DOE sites were also selected for review. A list of the sample set of DOD sites is provided in the body of the report in Table 5. The OR-SAGE tool was used to characterize the area within each site using the SMR SSEC established previously. ${ }^{1}$ The percentage of the site land area that met all of the siting criteria was estimated and discernment made regarding overall site acceptability. 


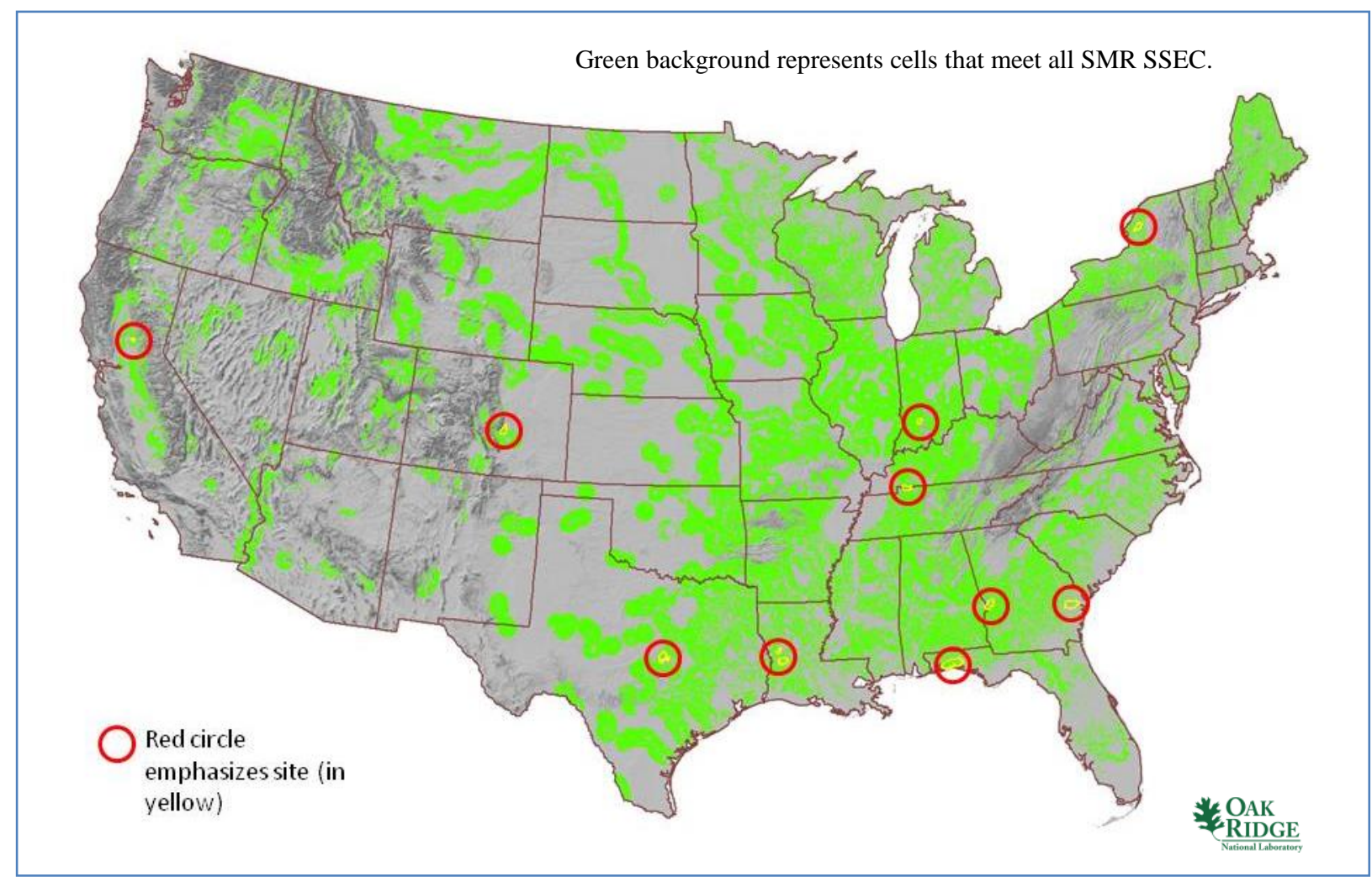

Fig. ES-2. Military base sample for SMR evaluation.

Nine of the ten DOD sites and four of the five DOE sites were judged to be favorable for siting an SMR. Results from the analyses of these DOD and DOE sites demonstrate that OR-SAGE provides useful insights for evaluating options and challenges related to powering these sites with an SMR. 



\section{BACKGROUND, INTRODUCTION, AND METHODOLOGY}

\subsection{Background}

The US Department of Energy (DOE) Office of Nuclear Energy (NE) has tasked Oak Ridge National Laboratory (ORNL) to support identification of candidate sites for deployment of new small modular reactor (SMR) power plants using a geographic information system (GIS) based tool that ORNL has developed. ${ }^{2}$ The tool, $\underline{\text { Oak }} \underline{\text { Ridge }} \underline{\text { Siting }}$ Analysis for Power Generation Expansion (OR-SAGE), is a flexible system being used to evaluate power plant siting options and considerations for a variety of power sources as well as identify nuclear waste storage siting options. The objective in developing OR-SAGE was to merge industry-accepted approaches for screening sites with the array of GIS data sources at ORNL to identify candidate areas for a particular application.

ORNL has employed the general concepts as presented in the 2002 Electric Power Research Institute (EPRI) Siting Guide 3 methodology developed to support early site permit (ESP) applications for purposes of screening sites for nuclear power plants to develop exclusionary, avoidance, and suitability criteria. The ESP concepts were subsequently used to develop exclusionary, avoidance, and suitability criteria for screening sites for a variety of power plants. For a given application, it is necessary to develop site selection and evaluation criteria (SSEC) that encompass a number of key screening criteria that essentially form the site environmental characterization for that application. These SSEC might include population density, slope, seismic activity, proximity to cooling water sources, proximity to hazardous facilities, avoidance of protected lands and floodplains, susceptibility to landslide hazards, and others. OR-SAGE is a visual, relational database. The SSEC are the fields of the database, and the GIS data for a given variable represent the values against which searches are performed. The visual database concept is demonstrated in Fig. 1. The database partitions the contiguous United States, a total of $7.2 \times 10^{8}$ hectares ( 1.8 billion acres), into 100 by $100 \mathrm{~m}$ ( 1 hectare or $\sim 2.5$ acres) cells. Therefore, the database is tracking just under 700 million individual land cells.

ORNL staff previously evaluated screening criteria for large and small nuclear power plants, advanced coal plants with carbon sequestration, wet and dry solar power technologies (excluding photovoltaic cells), and compressed air energy storage for EPRI. ${ }^{4}$ In initial evaluations, the principal differences between large and small nuclear power plants were cooling water demand and plant footprint. In the first phase of this SMR site-screening study supporting DOE-NE, the ORNL OR-SAGE siting tool was enhanced to focus on issues related specifically to the siting of SMRs. ${ }^{1}$ Applying SMR-centric screening criteria in OR-SAGE provides the ability to quickly analyze and characterize potential sites for SMR deployment. This report summarizes the characterization of a sample population (1) US Department of Defense (DOD) military base sites and (2) DOE sites for potential SMR deployment to power the uses and missions associated with these sites.

\footnotetext{
${ }^{2}$ G. T. Mays, T. J. Harrison, and O. A. Omitaomu, Preliminary Report on Siting Evaluation Tool for Commercial Nuclear Power Plants Developed by Oak Ridge National Laboratory, LTR/DOE-NE/Siting-2010/002, November 2010.

${ }^{3}$ E. Rodwell (Project Manager), Siting Guide: Site Selection and Evaluation Criteria for An Early Site Permit Application, 1006878, Final Report, Electric Power Research Institute, March 2002.

${ }^{4}$ G. T. Mays, R. J. Belles, O. A. Omitaomu, et al., Application of Spatial Data Modeling and Geographical Information Systems (GIS) for Identification of Potential Siting Options for Various Electrical Generation Sources, ORNL/TM-2011/157/R1, May 2012.
} 


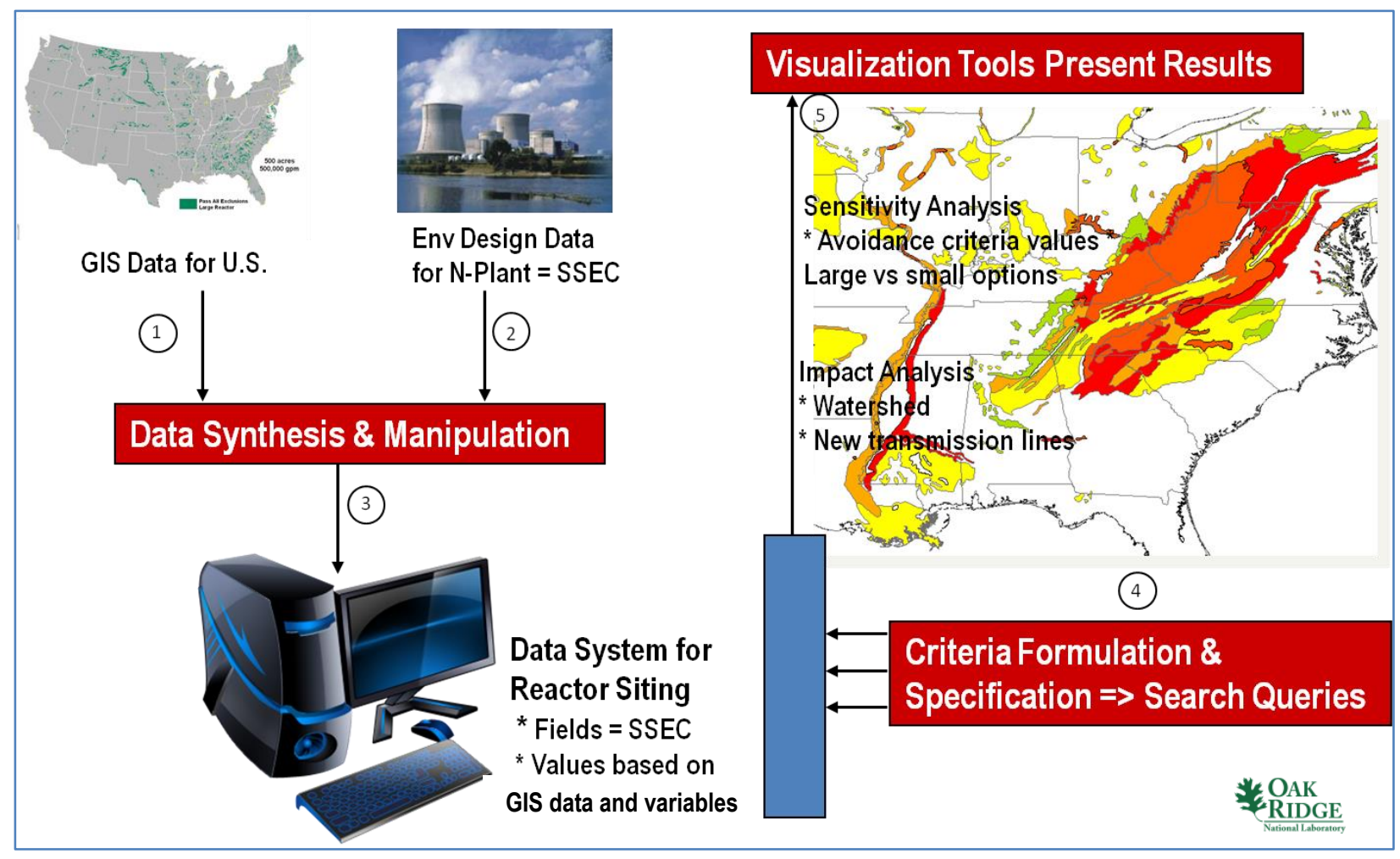

Fig. 1. OR-SAGE functions as a visual database.

\subsection{Introduction}

The objective of this SMR site-screening study is to support DOE-NE to enhance and extend the capability of the ORNL OR-SAGE siting tool to focus on issues related specifically to the siting of SMRs. Applying SMR-centric screening criteria in OR-SAGE will provide the ability to quickly analyze and characterize potential SMR sites from a national deployment perspective as well as from a site specific vantage point.

This report summarizes the third phase of the approach that ORNL developed for screening a sample set of DOD military bases and DOE sites for possible powering with an SMR; the methodology employed, including spatial modeling; and initial results for these sample plants. The objective in conducting this type of siting evaluation is demonstrate the capability to characterize specific sample DOD or DOE sites to identify any particular issues associated with powering these sites with an SMR; it is not intended to be a definitive assessment per se as to the absolute suitability of any particular site.

\subsection{Approach and Methodology}

The key to the approach for this study was to use industry-accepted practices in screening sites and then to employ the proper array of data sources and identify candidate areas through the considerable computational capabilities of GIS technology available at ORNL, as documented in the first phase of this SMR site-screening study supporting DOE-NE. ${ }^{1}$

The focus of the ORNL electrical generation source siting study is on identifying candidate areas from which potential SMR sites might be selected, stopping short of performing any detailed site evaluations or comparisons. This approach is designed to quickly screen for and characterize candidate areas. This approach is a top-down look at SMR siting on a national and regional scale. Building on these fundamentals, a bottom-up look at some specific sites that may be ripe for SMR deployment is possible. 
To that end, a sample set of DOD and DOE sites was selected and analyzed as outlined in Sects. 2 and 3 of this report, respectively.

In addition, it is desirable to have the capability to compare areas that meet all of the designated SMR site selection and evaluation criteria (SSEC), because some areas may actually prove to be more desirable than other areas. A similar comparison between areas with a single SMR SSEC that is not met may be desirable to better inform a decision about where to exert effort to engineer around a siting issue. Such a comparison or scoring of areas is discussed in a similar report on repowering coal sites with an SMR. ${ }^{5}$

\footnotetext{
${ }^{5}$ R. J. Belles, D. A. Copinger, G. T. Mays, O. A. Omitaomu, W. P. Poore, Geographic Information Systems Evaluation of Sample Coal Plant Sites to be Repowered with Small Modular Reactors, ORNL/TM-2013/109, March 2013.
} 



\section{EVALUATION OF SELECTED DOD SITES}

The initial phase of this project characterized all land in the contiguous United States regarding the potential for hosting a near-term SMR design. The initial analysis did not specifically consider proximity to load requirements or national interests (e.g., critical loads) brought about by the missions, mission support, and residents of large military bases. In contrast, this phase of the analysis seeks to characterize land occupied by a DOD site (e.g., military base) for possible deployment of an SMR. This assumes load requirements exist at such a site and there may be a benefit to replace or augment the power provided by off-site electric power plant.

Near-term SMRs are based on light-water reactor (LWR) technology with compact design features that are expected to offer a host of safety, siting, construction, and economic benefits. These smaller plants are ideally suited for small electric grids and for locations that cannot support large reactors, thus providing utilities with the flexibility to scale power production as demand changes by adding modules or reactors in phases to deploy additional power. The near-term SMR designs are based on existing pressurized-water reactor (PWR) technology. They are characterized as "integral" PWRs (iPWRs) since these plants will have major equipment such as pumps, steam generators, and pressurizers all located within the pressure vessel in an integrated, compact design. Individual reactor units in these designs are typically in the 25- to 250-MW(e) power range. Modular installations of iPWRs can range up to 540 MWe based on proposed vendor configurations.

Though other longer-term advanced SMR designs - such as high-temperature gas reactors, liquid metal reactors, and molten-salt reactors - were not analyzed in the initial phase of the SMR study, the screening parameters selected for the near-term iPWR reactors are expected to also encompass these advanced SMRs, with the exception of cooling water.

\subsection{Review of Nominal SMR Site Selection and Evaluation Criteria}

A summary of the site selection and evaluation criteria (SSEC) selected for SMR siting as documented in the first phase of this SMR site-screening study is provided below. These parameters are tracked on a cellby-cell basis for the entire contiguous United States. A more detailed discussion of each individual SSEC is available in the report ${ }^{1}$ on the first phase of this project.

- Land with a population density greater than 500 people per square mile (including a 10-mile buffer) is excluded

- Wetlands and open water are excluded

- Protected lands (e.g., national parks, historic areas, wildlife refuges) are excluded

- Land with a moderate or high landslide hazard susceptibility is excluded

- Land that lies within a 100 -year floodplain is excluded

- Land with a slope of greater than $18 \%\left(\sim 10^{\circ}\right)$ is excluded

- Land areas that are more than 20 miles from cooling water makeup sources with flow of at least 65,000 gpm, based on a 540 MWe modular iPWR installation, are excluded for nominal SMR plant applications

- Land too close to identified fault lines is excluded (the length of the fault line determines the standoff distance)

- Land located in proximity to hazardous facilities (airports and oil refineries) is avoided

- Land with safe shutdown earthquake (SSE) peak ground acceleration (2\% chance in a 50-year return period) greater than $0.5 \mathrm{~g}$ is excluded 
Based on preliminary design information and expert judgment, it is assumed that an SMR iPWR base design package (single unit or multi-module) from each vendor can easily be accommodated on a 50-acre footprint. In general, more than 50 acres is available at a typical coal-fired power plant.

The OR-SAGE tool tracks the SSEC parameters for each 100 by $100 \mathrm{~m}$ cell. As a result, not only can the cells that are clear of all the SSEC layer exclusions be displayed visually, but also cells that are tripped by one, two, or three or more exclusions can be tracked and displayed. This is known as the "SMR composite map" (Fig. 2). This is a powerful aspect to the OR-SAGE tool, because it allows areas with a limited number of siting challenges to also be identified. Engineering solutions may be available for areas with limited siting challenges.

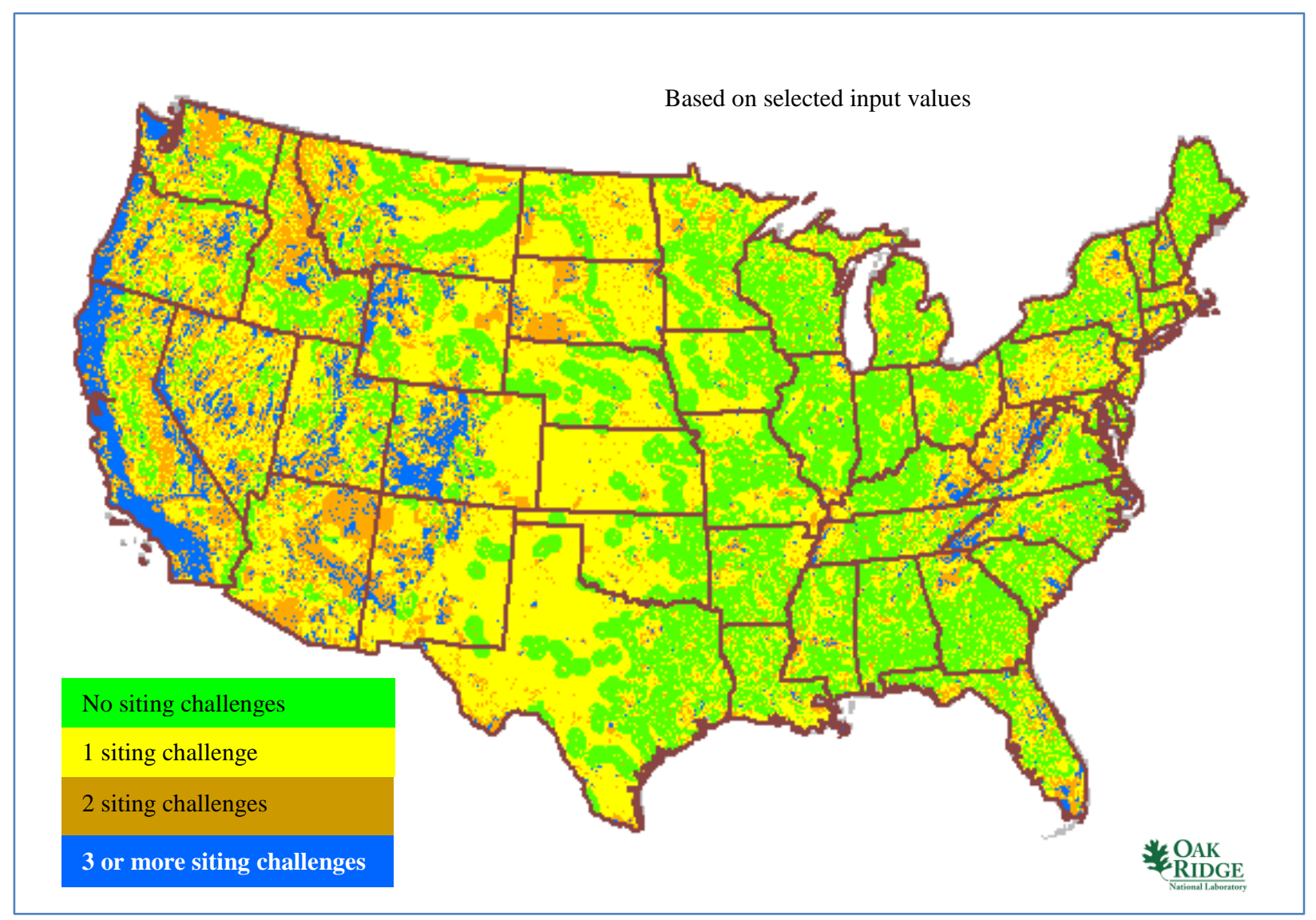

Fig. 2. Nominal, bounding SMR composite map detailing siting challenges.

\subsection{Selection of DOD Site Sample Set for Characterization}

According to the 2012 Homeland Security Infrastructure Protection (HSIP) Gold Database, ${ }^{6}$ there are over 700 active US military and US Coast Guard sites, bases, stations, ranges, or areas as shown as shown in Fig. 3. Neither DOD nor DOE-NE provided a prioritized list of base sites to evaluate. Therefore, a sample set of bases was selected to demonstrate the evaluation process using the OR-SAGE tool. Each sample DOD sites was evaluated for its potential to host an SMR to augment or replace the power supplied from off-site generating sources.

\footnotetext{
${ }^{6}$ National Geospatial-Intelligence Agency, Homeland Security Infrastructure Program-HSIP Gold 2012.
} 


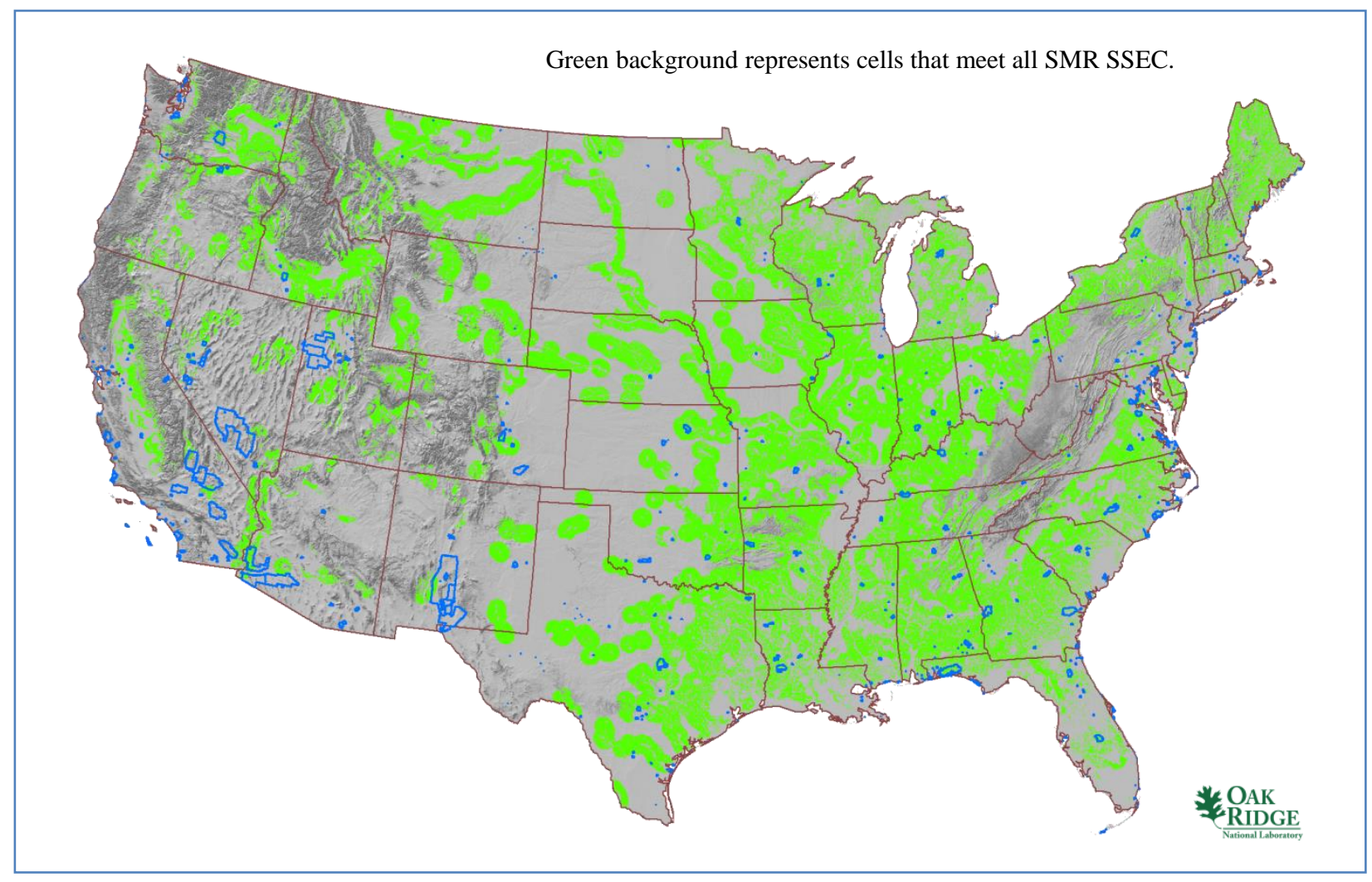

Fig. 3. All US military base locations relative to SMR aggregate map.

It was assumed that only larger DOD sites would be candidates for hosting an SMR facility. Therefore, only bases with area greater than 1000 acres were considered. At this minimum area, a 50-acre SMR site area would occupy $5 \%$ of a 1000-acre base. Engineering judgment suggested that any higher percentage of the base land would take away from the base mission. In addition, a larger base size should provide space to locate an SMR away from the immediate proximity of existing base facilities and training areas. There are 350 sites that include more than 1000 acres.

There are 150 military and Coast Guard sites that include 50 acres or less. By comparison, there are 135 sites that include more than 10,000 acres, which would offer even greater flexibility in siting an SMR remotely.

Only those military and Coast Guard bases, with area greater than 1000 acres that included land with no siting issues, a single siting issue, or within 5 miles of land that has no siting issues were considered for further evaluation. Essentially all DOD or Coast Guard sites that had two or more siting issues were not included for this initial round of characterization unless the site included space within 5 miles of land with no siting issues. The latter consideration was made in the event that nearby land could be offered as an alternative for an SMR site. Approximately 170 military bases passed this intermediate screening process. Because this study was conducted in order to demonstrate the applicability of the siting tool for typical uses, further reduction of the sample set size was pursued.

The remaining sites were then inversely ranked by base size on the premise that the larger the base, the more potential SMR siting possibilities. Several qualitative criteria were then also employed to additionally reduce the number of sites to be reviewed, such as selecting diverse Army, Air Force, and Navy bases from across the country. Also, sites labeled as "ranges," National Guard or Marine "camps," "arsenals," or "proving grounds" were excluded due to higher perceived challenges associated with the 
missions of these sites or the reasoning that they had a reduced number of permanent staff and resident personnel, which would mean a likely lower need for electric power.

Seven Army bases, two Air Force Bases, and one Navy station were ultimately selected as a representative sample for evaluation. These sites are listed in Table 1 and shown in Fig. 4. All of these sites have ample areas with no siting challenges to support an SMR site of at least 50 acres. With regard to siting SMRs outside of a military facility, airports are a consideration. Since airfields within a military site were not excluded, the impact of any airfields associated with the sample sites selected is discussed in the individual assessment of each site.

Table 1. Military base sample for review

\begin{tabular}{|l|l|}
\hline \multicolumn{1}{|c|}{ Name } & \multicolumn{1}{c|}{ State } \\
\hline Beale Air Force Base & California \\
\hline Eglin Air Force Base & Florida \\
\hline Fort Benning & Georgia \\
\hline Fort Campbell & Kentucky/Tennessee \\
\hline Fort Carson & Colorado \\
\hline Fort Drum & New York \\
\hline Fort Hood & Texas \\
\hline Fort Polk & Louisiana \\
\hline Fort Stewart & Georgia \\
\hline Naval Surface Warfare Center - Crane & Indiana \\
\hline
\end{tabular}

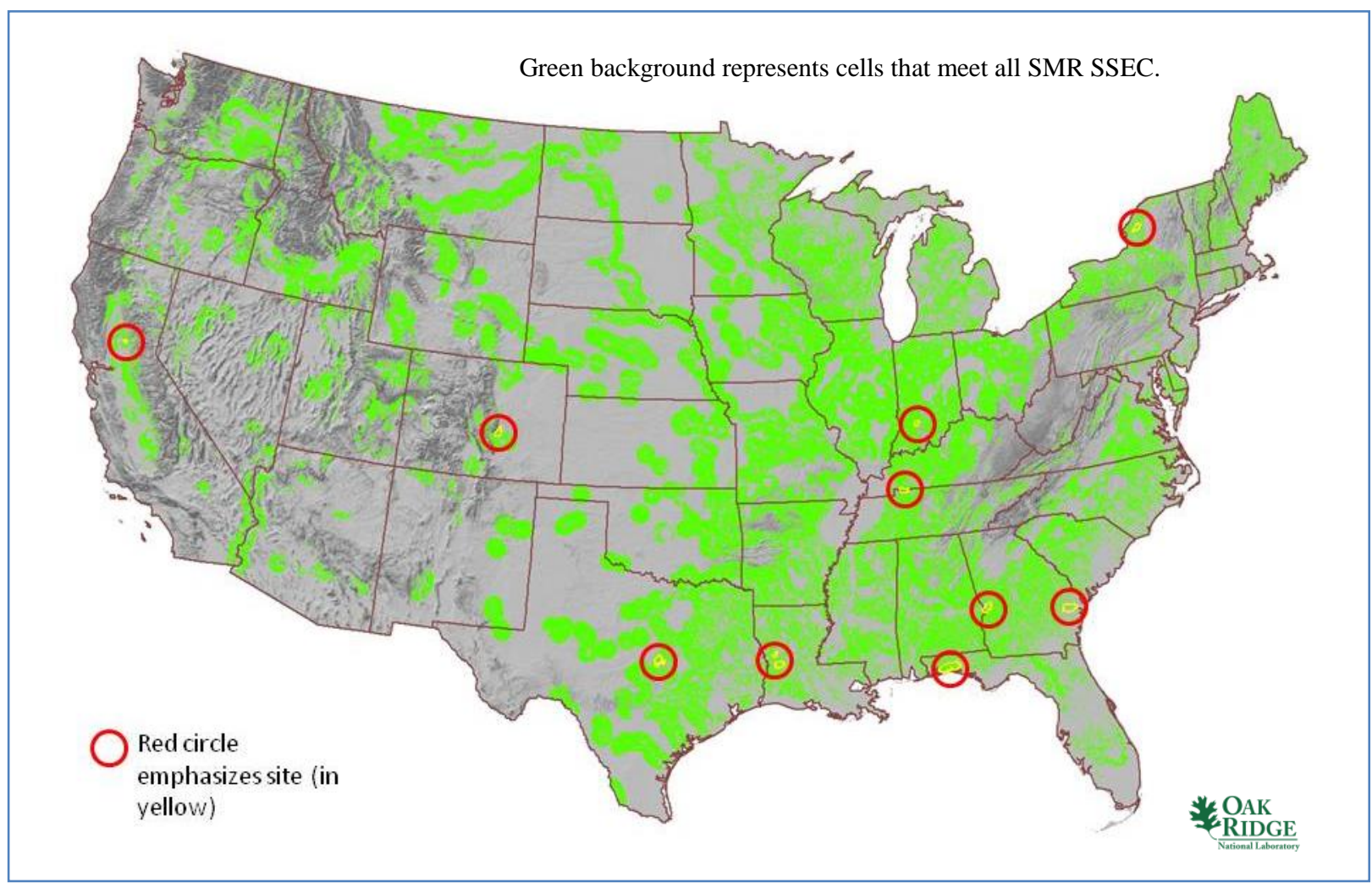

Fig. 4. Military base sample for SMR evaluation. 


\subsection{DOD Site Evaluation Process}

A data package and analysis for each site in the sample set of 10 military bases or stations was prepared. These site summaries are available in Appendix A. Each site summary in Appendix A includes specific detail regarding its location and a location map similar to the example shown in Fig. 5. In addition, a table of statistics similar to that shown in Table 2 supports a description of the site.

Table 2 includes

- Population within $0.5,1,5$, and 10 miles, which allows a population density calculation

- Distance to 400, 800, 1600, and $3200 \mathrm{MW}(\mathrm{e})$ grid capacity $^{7}$

- Nearest cities with populations greater than $10,000,50,000,100,000$, and 500,000

- Distance to cooling water makeup source greater than 50,000, 100,000, 200,000, and 500,000 gpm stream flow

- Note that a 540 MWe modular iPWR installation requires approximately 65,000 gpm stream flow assuming no more than $10 \%$ of the available stream flow is used for power production

- Available cooling water makeup is based on current consumption. The cooling water already used by a given coal station may be sufficient for a replacement iPWR SMR

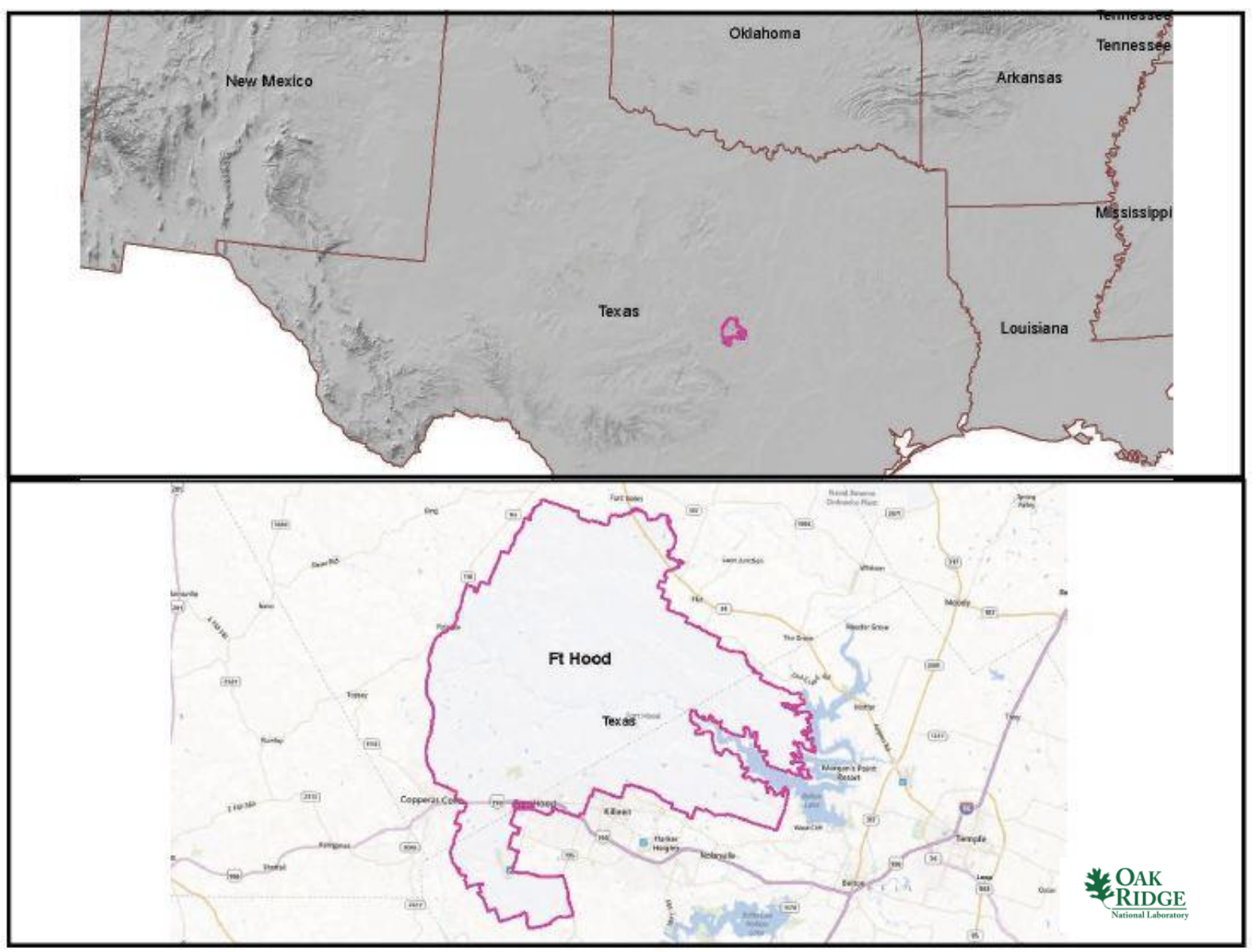

Fig. 5. Sample military base location map (Fort Hood, Texas).

\footnotetext{
${ }^{7}$ Grid capacity data is based on 2004 data
} 
Table 2. Sample DOD site statistical summary (Fort Hood, Texas)

\begin{tabular}{|c|c|c|c|}
\hline \multicolumn{2}{|l|}{$\begin{array}{l}\text { Population } \\
\text { Population Within }\end{array}$} & \multicolumn{2}{|l|}{$\begin{array}{l}\text { Utility } \\
\text { Distance to Grid Capacity }\end{array}$} \\
\hline $0.5 \mathrm{mi}$ of Site Boundary & $\sim 275,000$ & $>400 \mathrm{MWe}$ & $\sim 34 \mathrm{mi}$ \\
\hline $1 \mathrm{mi}$ of Site Boundary & $\sim 332,000$ & $>800 \mathrm{MWe}$ & $\sim 34 \mathrm{mi}$ \\
\hline $5 \mathrm{mi}$ of Site Boundary & $\sim 593,000$ & $>1600 \mathrm{MWe}$ & $\sim 77 \mathrm{mi}$ \\
\hline $10 \mathrm{mi}$ of Site Boundary & $\sim 820,000$ & $>3200 \mathrm{MWe}$ & $\sim 708 \mathrm{mi}$ \\
\hline \multicolumn{2}{|c|}{ Nearest City with Population } & \multicolumn{2}{|c|}{ Distance to Cooling Water } \\
\hline$>10,000$ & Copperas Cove, TX & $>50,000 \mathrm{gpm}$ & $\sim 0.1 \mathrm{mi}$ (Fish Stream) \\
\hline$>50,000$ & Temple, TX & $>100,000 \mathrm{gpm}$ & $\sim 0.1 \mathrm{mi}$ (Leon River) \\
\hline$>100,000$ & Kileen, TX & $>200,000 \mathrm{gpm}$ & $\sim 0.1 \mathrm{mi}$ (Leon River) \\
\hline$>500,000$ & Austin, TX & $>500,000 \mathrm{gpm}$ & $\sim 33 \mathrm{mi}$ (Colorado River) \\
\hline \multicolumn{2}{|l|}{ Geotechnical } & \multicolumn{2}{|l|}{ Accessibility } \\
\hline Max Earthquake Acceleration & $<0.3 \mathrm{~g}$ & Distance to Major Roadway & $\sim 6 \mathrm{mi}$ (Interstate 35 ) \\
\hline Max Slope & $\sim 30 \%$ & Distance to Water Transport & $\sim 153 \mathrm{mi}$ (Pacific Deep) \\
\hline Nearest Fault Line & $\sim 219 \mathrm{mi}$ (Oklahoma) & Distance to Rail Transport & $\sim 0.1 \mathrm{mi}(\mathrm{BNSF})$ \\
\hline Nearest Hazard Site & $\begin{array}{l}\text { On Site (Airport- } \\
\text { Robert Gray AAF) }\end{array}$ & Distance to Airport & $\begin{array}{c}\sim \text { On Site (Robert Gray } \\
\text { AAF) }\end{array}$ \\
\hline
\end{tabular}

- Geotechnical information including

$\circ \quad$ Maximum earthquake acceleration (if greater than $0.3 \mathrm{~g}$ )

- Maximum slope (if greater than $12 \%$ )

$\circ \quad$ Nearest fault line

- Nearest hazardous site

- Accessibility by road, water, rail, and air

In each DOD site evaluation summary, a satellite aerial view of each site with is provided. This provides a convenient look at the area geography, including major nearby roads, rivers, and population activity such as nearby towns and off-site and on-site developments, cantonments, and major facilities and structures. A sample aerial image of a DOD site is provided in Fig. 6.

Following the satellite view of the coal station, a screening criteria summary bar, or "dashboard" chart, for the site provides a quick look at what siting issues may exist. The SMR SSEC that are not met within the site are indicated. If an SMR siting criterion box is green, there is no potential siting issue. Hatched purple and green indicates a "partial" siting issue for some part of the site, and solid purple indicates that the particular SMR criterion is an issue for that area of the site. The SMR SSEC are listed; their respective values appear below the summary bar for reference. A sample DOD site screening criteria dashboard is provided in Table 3.

Following the DOD site screening criteria dashboard in each evaluation summary is a localized composite map based on the national composite map shown in Fig. 2. At the local level, individual 100 by $100 \mathrm{~m}$ cells can be identified. The cells are color-coded, as in Fig. 2, to quickly gain insight to compounded SMR siting criteria that are not met. A sample DOD site composite map is shown in Fig. 7. A green square has no siting issues relative to the selected SMR SSEC values; a yellow square has a single siting issue; an orange square has two siting issues; and a blue square has three or more siting issues.

Following the DOD site composite map, ten smaller individual siting criterion maps are provided to identify the locations where the selected individual parameter values may not be met within the site. Any areas shown in a magenta color do not meet the individual SSEC criterion at the value selected for SMR screening. A sample individual SSEC map is shown in Fig. 8. 


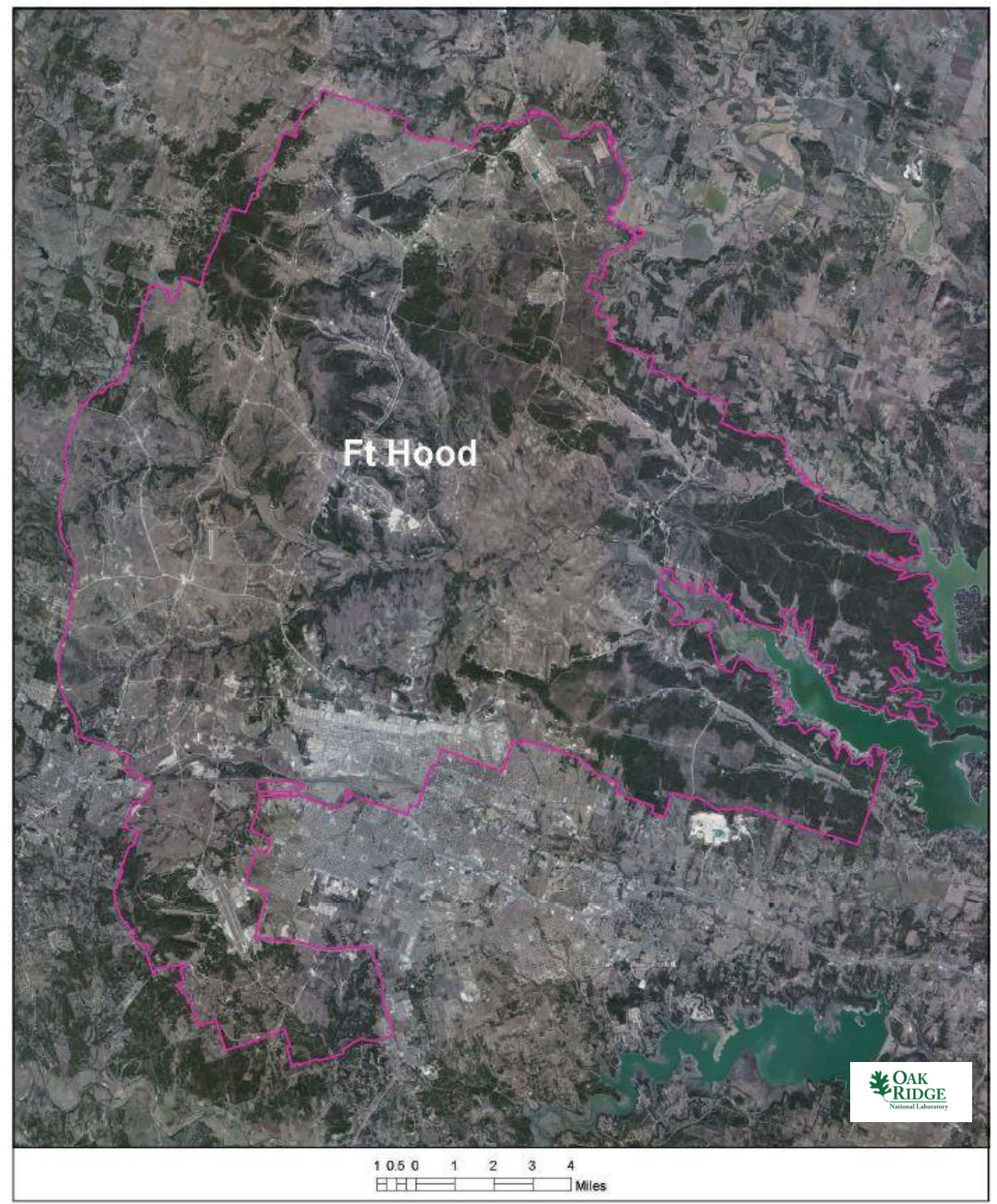

Fig. 6. Sample satellite view of DOD site (Fort Hood, Texas). 
Table 3. Sample DOD site criteria summary (Fort Hood, Texas)

\section{Screening Criteria Summary Bar}

(Colored Boxes indicate Screening Results)

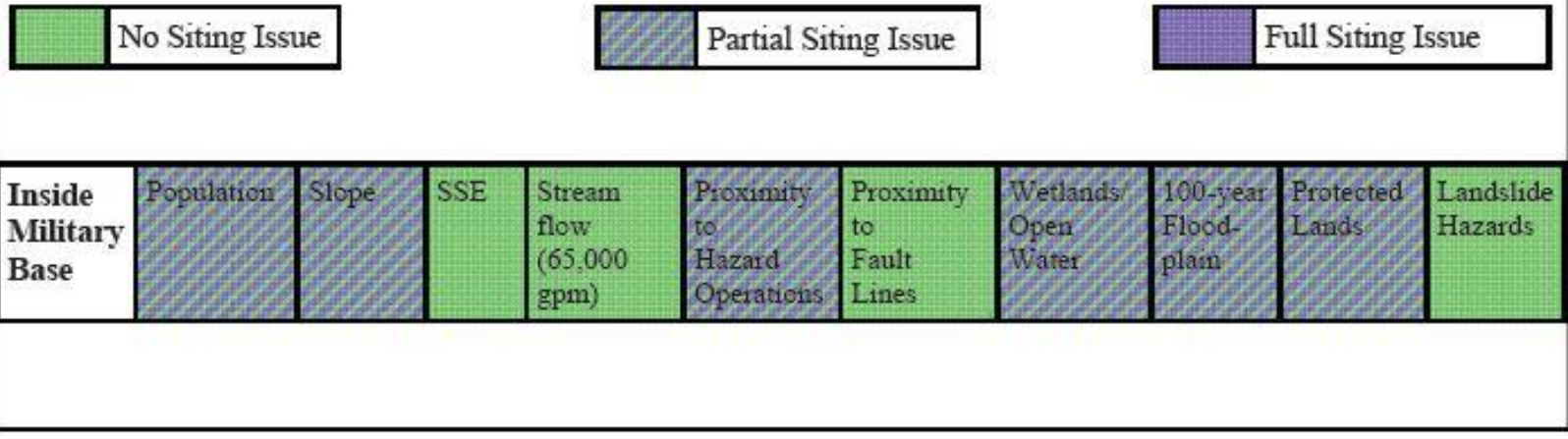

\begin{tabular}{|l|c|}
\hline \multicolumn{2}{|c|}{ Screening Criteria Table } \\
\hline \multicolumn{1}{|c|}{ Criteria } & Value \\
\hline Population Density within 10 miles (people/square mile) & $>500$ \\
\hline Slope & $>18 \%$ \\
\hline Safe shutdown earthquake (ground acceleration) & $>0.5$ \\
\hline Streamflow/cooling water make-up (gpm) & $<65,000$ \\
\hline Proximity to hazardous operations - buffer (mile) & Depends on hazardous operation ${ }^{1}$ \\
\hline Proximity to fault lines - buffer (mile) & Depends on length of fault \\
\hline Wetlands/Open Water & - \\
\hline 100-year floodplain & - \\
\hline Protected lands & - \\
\hline Landslide hazard (moderate and high) & - \\
\hline
\end{tabular}




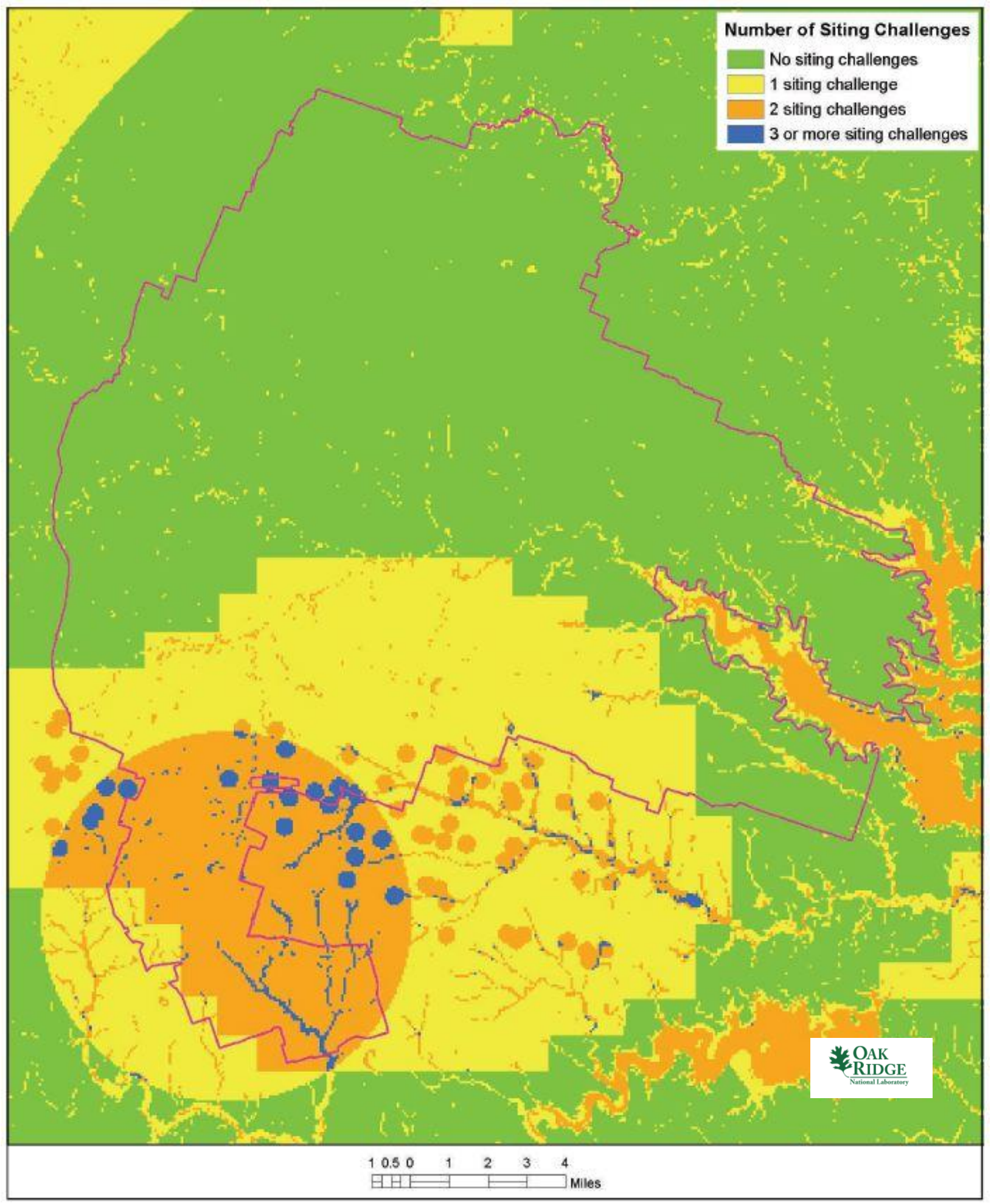

Fig. 7. Sample DOD site composite map (Fort Hood, Texas). 


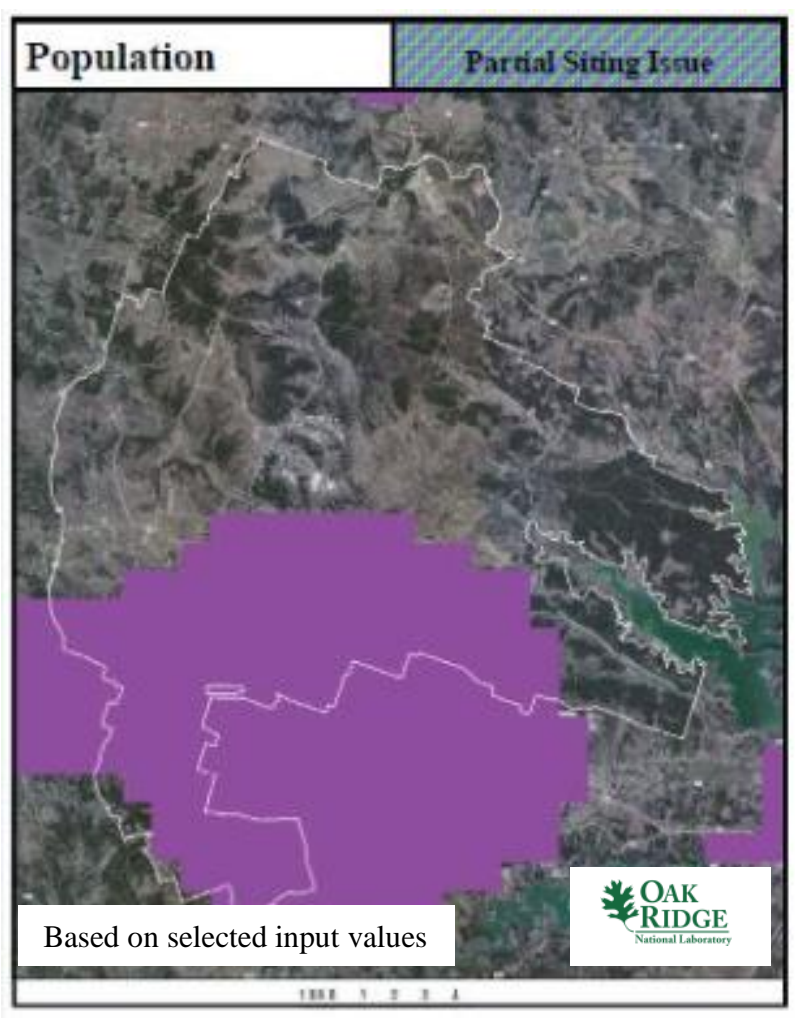

Fig. 8. Sample individual SSEC criterion map (areas in magenta do not meet criterion).

Based on the detail provided in each DOD site summary package, a high-level evaluation of the site is offered. A brief discussion about the site is provided and a summary of the suitability of a site potential for an SMR is provided and observations regarding availability of site security features and forces to protect a potential on-site nuclear facility and the familiarity of site personnel to accommodate an SMR based on high technology, national security-related missions and support activities typical of the sites.

\subsection{Summary of DOD Site Evaluations}

Each DOD site was evaluated visually using Google Earth and similar Internet mapping resources to identify proximity to nearby towns, structures or facilities representing potential hazards.

The OR-SAGE tool identified that nine of the ten sample sites easily meet all of the SMR SSEC at the selected values for at least a significant fraction of the site area. These nine sites met multiple conventional standards for consideration of siting an SMR. The specific evaluations of each site indicated that there were no current or near-term foreseeable SMR SSEC siting concerns which should preclude these sites from further SMR siting consideration. Beale Air Force Base is more limited with regards to space as noted in the evaluation located in Appendix A.

A short summary of the DOD site evaluations is available in Table 4. This table is ordered by the effective acreage ${ }^{6}$ evaluated to be available for locating an SMR to provide site power. Fort Hood in Texas, Fort Stewart in Georgia, and Eglin Air Force Base in Florida stand out as having well over 100,000 acres available for SMR deployment. The Naval Surface Warfare Center-Crane Division in Indiana and Fort Campbell in Kentucky/Tennessee have less acreage; however, these sites standout as having a high percentage of the site area amenable for SMR siting. The runway at Beale Air Force Base in California combined with the overall small size of the site would make it more difficult to support siting an SMR at this location. 
Table 4. DOD site summary ${ }^{6}$

\begin{tabular}{|l|c|c|c|l|}
\hline \multicolumn{1}{|c|}{ Site } & $\begin{array}{c}\text { Encompassed } \\
\text { acreage }\end{array}$ & $\begin{array}{c}\text { Percentage } \\
\text { evaluated as } \\
\text { favorable for } \\
\text { siting an SMR }\end{array}$ & $\begin{array}{c}\text { Effective } \\
\text { favorable } \\
\text { SMR } \\
\text { acreage }\end{array}$ & \multicolumn{1}{|c|}{ Notes } \\
\hline Fort Hood & 193,000 & $66 \%$ & 127,000 & $\begin{array}{l}\text { Continuous area favorable for } \\
\text { SMR siting }\end{array}$ \\
\hline Fort Stewart & 253,000 & $50 \%$ & 127,000 & $\begin{array}{l}\text { Wetlands and open water are } \\
\text { present across the site 100-year } \\
\text { floodplain is also an impact. } \\
\text { Runway reduces available land for } \\
\text { SMR siting }\end{array}$ \\
\hline Eglin Air Force Base & 420,000 & $30 \%$ & 126,000 & $\begin{array}{l}\text { Multiple runways at various } \\
\text { locations greatly reduce available } \\
\text { land }\end{array}$ \\
\hline Fort Benning & 165,000 & $50 \%$ & 83,000 & $\begin{array}{l}\text { Three large distinct areas are most } \\
\text { favorable for SMR siting }\end{array}$ \\
\hline Fort Campbell & 93,000 & $80 \%$ & 74,000 & $\begin{array}{l}\text { Continuous area favorable for } \\
\text { SMR siting }\end{array}$ \\
\hline Fort Carson & 122,000 & $60 \%$ & 73,000 & $\begin{array}{l}\text { Continuous area favorable for } \\
\text { SMR siting }\end{array}$ \\
\hline Fort Drum & 97,000 & $75 \%$ & 73,000 & $\begin{array}{l}\text { Wetlands and open water are } \\
\text { present across the site }\end{array}$ \\
\hline Fort Polk & 180,000 & $40 \%$ & 72,000 & $\begin{array}{l}\text { Runway reduces available land for } \\
\text { SMR siting }\end{array}$ \\
\hline $\begin{array}{l}\text { Naval Surface Warfare } \\
\text { Center-Crane Division }\end{array}$ & 55,000 & $95 \%$ & 52,000 & $\begin{array}{l}\text { Assumes runway avoidance is } \\
\text { limited to 3 miles. If left at } \\
5 \text { miles, then the site becomes } \\
\text { space limited }\end{array}$ \\
\hline Beale Air Force Base & 21,000 & $25 \%$ & 5,000 & \\
\hline
\end{tabular}

This is only a sample size of 10 out of approximately 170 DOD sites with at least 1000 acres that were initially identified by OR-SAGE as meeting all the SMR SSEC for at least some areas of the sites. Since sites on the high end of available space were initially selected, a high percentage of the sample sites were expected to meet multiple conventional standards for consideration of siting an SMR. As a result, it is difficult to extrapolate the results of this evaluation sampling to the entire spectrum of 170 sites meeting the initial selection criteria. It is assumed that as sites approach the 1,000 acre size, fewer and fewer sites would be found amenable for siting an SMR. 



\section{EVALUATION OF SELECTED DOE SITES}

The selected DOE sites were evaluated in a very similar manner as the DOD sites presented in Section 2. The background associated with the evaluation is not repeated here.

\subsection{Review of Nominal SMR Site Selection and Evaluation Criteria}

ORNL selected the five DOE sites shown in Table 5. These sites were chosen for review based on assumed adequately sized sites, geographic diversity, and a historical association with nuclear facilitiesalmost a given for a DOE site. Fig. 9 shows these sites on the SMR aggregate map.

Table 5. DOE sites for review

\begin{tabular}{|l|l|}
\hline \multicolumn{1}{|c|}{ Name } & \multicolumn{1}{c|}{ State } \\
\hline Hanford Site & Washington \\
\hline Idaho Site & Idaho \\
\hline Oak Ridge Site & Tennessee \\
\hline Sandia Site & New Mexico \\
\hline Savannah River Site & South Carolina \\
\hline
\end{tabular}

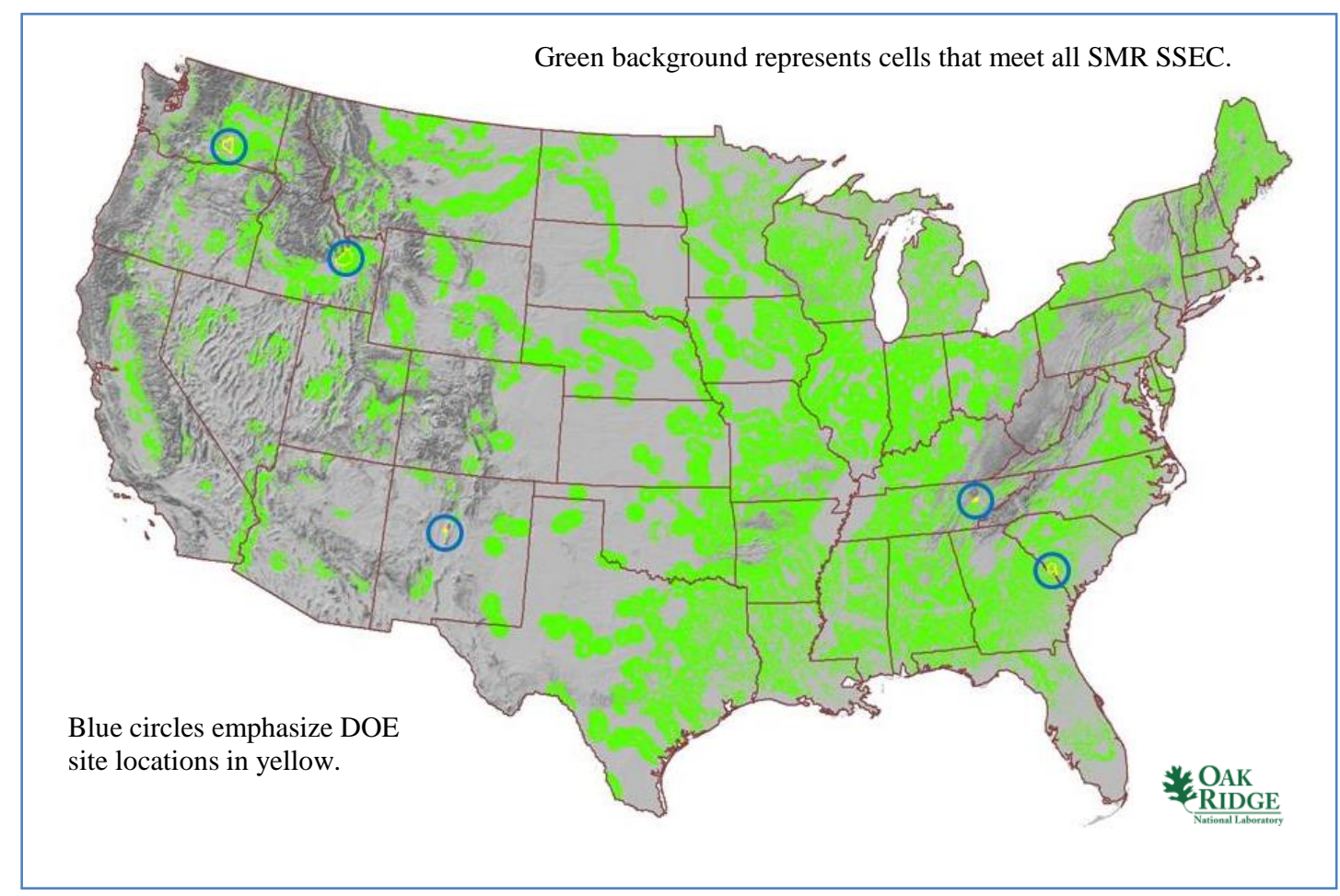

Fig. 9. DOE sites for review. 


\subsection{DOE Site Evaluation Process}

A data package and analysis for each of the five DOE sites was prepared similarly to the DOD site reviews outlined in Section 2.3. These site summaries are available in Appendix B.

\subsection{Summary of DOE Site Evaluations}

The OR-SAGE tool identified that four of the five DOE sites meet all of the SMR SSEC at the selected values for at least a significant fraction of the site area. The Sandia site was found not to be acceptable because several SSEC are not met, as noted in the evaluation located in Appendix B.

A short summary of the DOE site evaluations is available in Table 6. This table is ordered by the effective acreage $^{6}$ evaluated to be available for locating an SMR to provide site power. Idaho National Laboratory and the Savannah River Site in South Carolina stand out as having well over 100,000 acres available for SMR deployment. Both of these sites also standout because they have a high percentage of the site area amenable for SMR siting. Multiple overlapping issues combined with the overall small size of the Sandia site would make it more difficult to support siting an SMR at this location.

Table 6. DOE site summary ${ }^{6}$

\begin{tabular}{|l|c|c|c|l|}
\hline \multicolumn{1}{|c|}{ Site } & $\begin{array}{c}\text { Encompassed } \\
\text { acreage }\end{array}$ & $\begin{array}{c}\text { Percentage evaluated } \\
\text { as favorable for } \\
\text { siting an SMR }\end{array}$ & $\begin{array}{c}\text { Effective } \\
\text { favorable SMR } \\
\text { acreage }\end{array}$ & \multicolumn{1}{|c|}{ Notes } \\
\hline $\begin{array}{l}\text { Idaho National } \\
\text { Laboratory }\end{array}$ & 570,000 & $95 \%$ & 542,000 & \\
\hline $\begin{array}{l}\text { Savannah } \\
\text { River Site }\end{array}$ & 200,000 & $80 \%$ & 160,000 & $\begin{array}{l}\text { Wetlands and open water are } \\
\text { present across the site }\end{array}$ \\
\hline Hanford & 380,000 & $20 \%$ & 76,000 & $\begin{array}{l}\text { One continuous area favorable } \\
\text { for SMR siting }\end{array}$ \\
\hline Oak Ridge & 31,000 & $50 \%$ & 16,000 & $\begin{array}{l}\text { Town population impacts } \\
\text { northern area. Otherwise } \\
\text { workforce is centrally located in } \\
\text { distinct areas }\end{array}$ \\
\hline Sandia & 25,000 & $0 \%$ & 0 & $\begin{array}{l}\text { Lack of stream flow cooling and } \\
\text { multiple partial site limitations }\end{array}$ \\
\hline
\end{tabular}

This is only a sample size of 5 out of approximately 40 DOE sites. Since sites on the high end of available space were initially selected, a high percentage of the sample sites were expected to meet multiple conventional standards for consideration of siting an SMR. As a result, it is difficult to extrapolate the results of this evaluation sampling to the entire spectrum of 40 DOE sites. Each DOE site would need to be evaluated separately. 


\section{SUMMARY}

Results from the analyses of these DOD and DOE sites demonstrate that OR-SAGE provides useful insights for evaluating options and challenges related to powering these sites with an SMR. Overall, nine of the ten DOD sites and four of the five DOE sites reviewed for this study meet multiple conventional standards for consideration of siting an SMR. The sites are typically quite large-a criterion for their initial selection - and have considerable land areas that satisfy all of the siting criteria examined. Note that site-specific hazards such as training ranges, ordnance handling, storage areas, etc., were not considered. Some on-site hazards such as airfields were qualitatively considered.

The DOE sites all have historical experience and familiarity with nuclear facilities and missions. The four sites considered acceptable have been and are home to multiple nuclear reactors and have land areas available, staff familiar with nuclear missions, and security capabilities needed for nuclear power plants.

The DOD sites also support high technology and national security-related missions and are familiar with the similar technologies associated with operation of a nuclear power plant. They have adequate land areas available, staff considered capable and familiar with high technology activities similar to nuclear power plant operations, and necessary security capabilities.

Beyond designating areas as meeting all the siting criteria at a specific set of threshold values, specifically the green space in the SMR composite map shown in Fig. 2, it is desirable to have the capability to compare areas that meet all of the designated SMR SSEC. This allows further emphasis to be directed toward areas that may ultimately prove to be more desirable than other areas. This scoring technique was demonstrated in a companion study. ${ }^{5}$ A national map of areas of the US suitable for SMR siting is shown in Fig. 10. In this figure, the best suitable areas are shown as dark green, better areas are shown as medium green, and good areas are shown as light green. All three green hues meet all of the SMR siting criteria at the select set of values as documented in the first phase of this SMR site-screening study. ${ }^{1}$ The darkest green area represents $21.6 \%$ of the contiguous United States. This includes land in close proximity to major cities such as Chicago, Nashville, Atlanta, Dallas, and Houston. The medium green area represents $15.5 \%$ of the contiguous United States. This includes suitable land with tremendous water resources but less power demand such as seen in Montana. Land scoring low in the stream flow element reflecting a reliance on cooling from lakes and reservoirs is also scored in the medium green or better category. This includes large areas within Wisconsin, Alabama, and Georgia. Additional scoring elements could add greater differentiation. Such a database cell comparison methodology could assist in the evaluation of SMR site selection at DOD and DOE sites. 


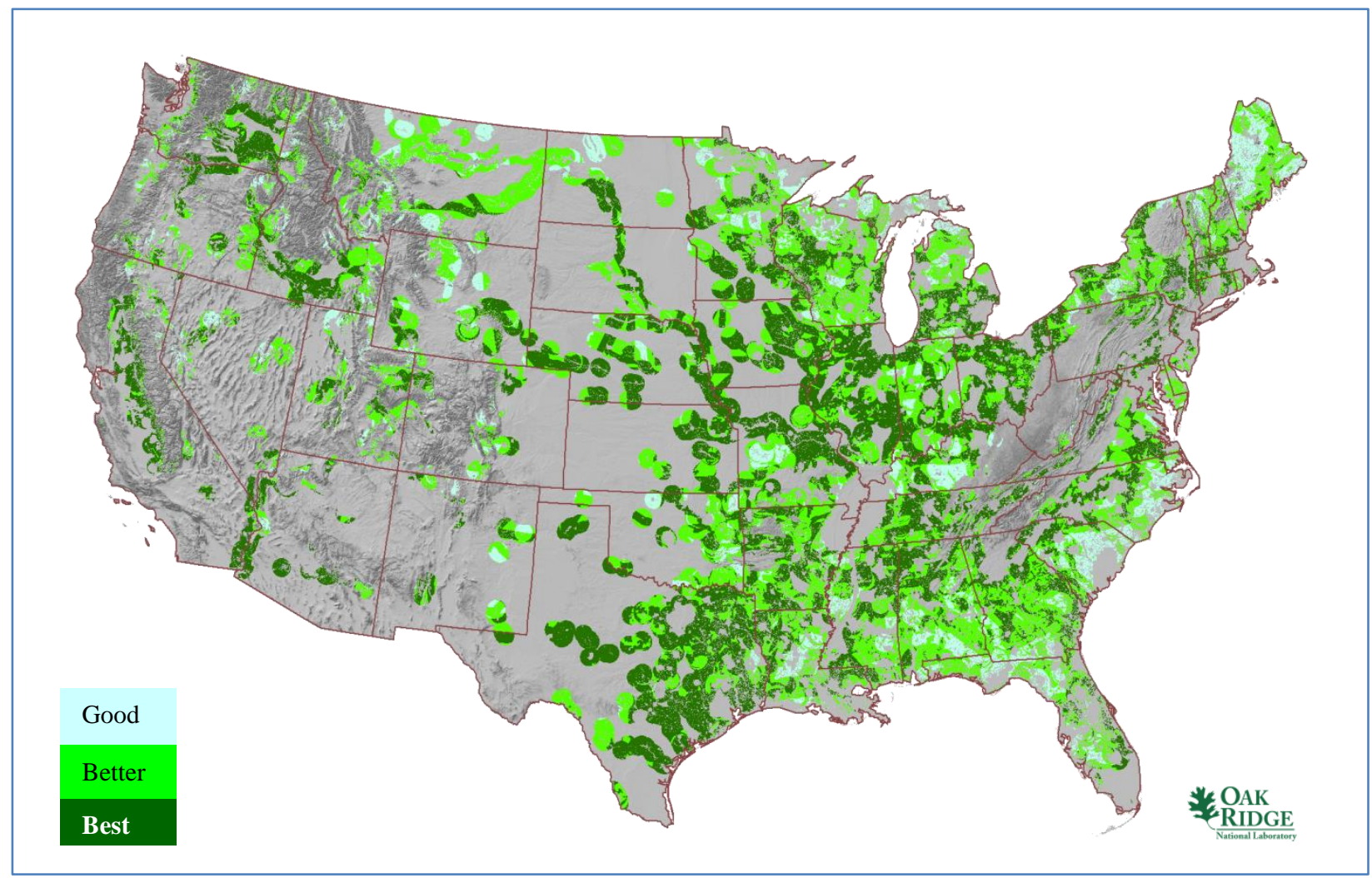

Fig. 10. National SMR base map with scoring comparison. 


\section{APPENDIX A - DOD SITE EVALUATIONS}

\section{A.1 BEALE AIR FORCE BASE}

\section{A.1.1 Location Detail}

As shown in Fig. A.1, Beale Air Force Base is located on about 21,000 acres ${ }^{6}$ (about 33 square miles) in the central area of northern California, about 10 miles east of the city of Marysville. Beale Air Force Base is home to the 9th Reconnaissance Wing. Interstate 80 is about 20 miles east of the base, and Interstate 5 is about 35 miles west.

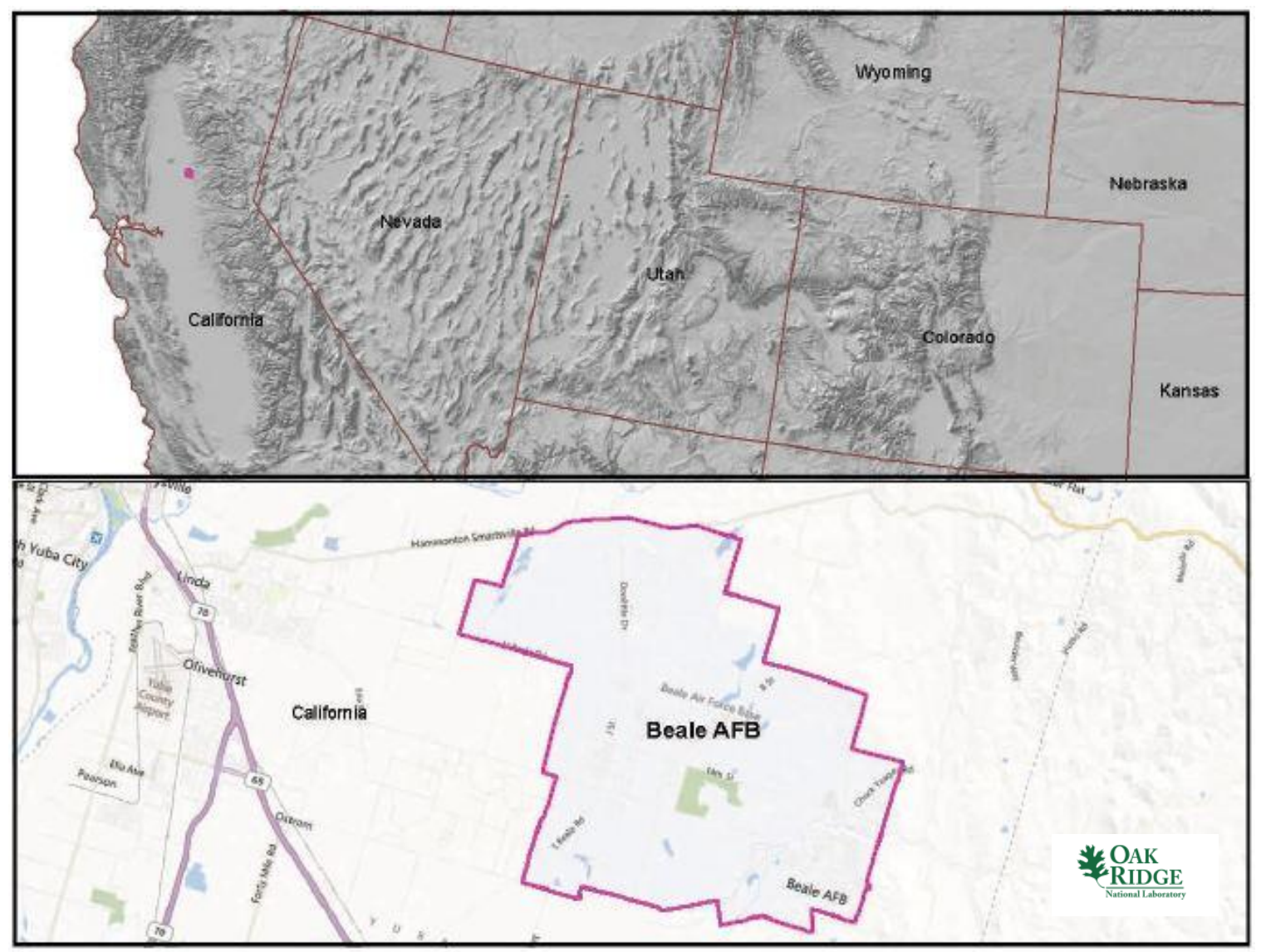

Fig. A.1. Beale Air Force Base.

\section{A.1.2 Site Description and Status}

The 9th Reconnaissance Wing is located at Beale Air Force Base. Approximately 4,000 military personnel are on-site at any given time. ${ }^{8}$ About 1,300 people live on the base. Descriptions of the installation, missions, and base history are readily available on the Internet. ${ }^{9}, 10$

\footnotetext{
${ }^{8} \mathrm{http}: / /$ en.wikipedia.org/wiki/Beale_Air_Force_Base

${ }^{9} \mathrm{http} / / / \mathrm{www} \cdot$ beale.af.mil/

${ }^{10} \mathrm{http}: / / \mathrm{www}$.military.com/base-guide/beale-air-force-base
} 
Services and resources are available on the base for military staff, families, employees, and services contractors including lodging and housing, medical care, dining, library, cultural and recreational amenities, and other goods and services. ${ }^{11}$

As noted in Table A.1, the nearest major fault line based on USGS data is noted to be just east of the eastern perimeter of the base. The maximum safe shutdown earthquake for the site is below $0.3 \mathrm{~g}$ peak ground acceleration. The maximum slope on the site is about 15\%. Greater than 100,000 gpm of cooling water makeup is available from the Bear River. Greater than 500,000 gpm of cooling water makeup is available from the Yuba River. Major highways, water transport, and rail transport are nearby.

Table A.1. Beale Air Force Base site statistics

\begin{tabular}{|c|c|c|c|}
\hline \multicolumn{2}{|l|}{$\begin{array}{l}\text { Population } \\
\text { Population Within }\end{array}$} & \multicolumn{2}{|l|}{$\begin{array}{l}\text { Utility } \\
\text { Distance to Grid Capacity }\end{array}$} \\
\hline $0.5 \mathrm{mi}$ of Site Boundary & $\sim 24,000$ & $>400 \mathrm{MWe}$ & $\sim 12 \mathrm{mi}$ \\
\hline 1 mi of Site Boundary & $\sim 30,000$ & $>800 \mathrm{MWe}$ & $\sim 12 \mathrm{mi}$ \\
\hline $5 \mathrm{mi}$ of Site Boundary & $\sim 131,000$ & $>1600 \mathrm{MWe}$ & $\sim 13 \mathrm{mi}$ \\
\hline $10 \mathrm{mi}$ of Site Boundary & $\sim 393,000$ & $>3200 \mathrm{MWe}$ & $\sim 196 \mathrm{mi}$ \\
\hline \multicolumn{2}{|c|}{ Nearest City with Population } & \multicolumn{2}{|c|}{ Distance to Cooling Water } \\
\hline$>10,000$ & Linda, CA & $>50,000 \mathrm{gpm}$ & $\sim 2.0 \mathrm{mi}$ (Bear River) \\
\hline$>50,000$ & Rocklin, CA & $>100,000 \mathrm{gpm}$ & $\sim 2.0 \mathrm{mi}$ (Bear River) \\
\hline$>100,000$ & Roseville, CA & $>200,000 \mathrm{gpm}$ & $\sim 6.0 \mathrm{mi}$ (Yuba River) \\
\hline$>500,000$ & San Francisco, CA & $>500,000 \mathrm{gpm}$ & $\sim 6.0 \mathrm{mi}$ (Yuba River) \\
\hline \multicolumn{2}{|l|}{ Geotechnical } & \multicolumn{2}{|l|}{ Accessibility } \\
\hline Max Earthquake Acceleration & $<0.3 \mathrm{~g}$ & Distance to Major Roadway & $\sim 17 \mathrm{mi}$ (Interstate 80$)$ \\
\hline Max Slope & $\sim 15 \%$ & Distance to Water Transport & $\sim 6 \mathrm{mi}$ (Bering Sea Access) \\
\hline Nearest Fault Line & $\sim 1.0 \mathrm{mi}$ (California) & Distance to Rail Transport & $\sim 0.1 \mathrm{mi}(\mathrm{USG})$ \\
\hline Nearest Hazard Site & $\begin{array}{l}26 \text { mi (Airport- } \\
\text { Sacramenta Int' } 1 \text { ) }\end{array}$ & Distance to Airport & $\sim 26 \mathrm{mi}$ (Sacramento Int' 1$)$ \\
\hline
\end{tabular}

\section{A.1.3 Aerial Imagery}

The aerial imagery in Fig. A.2 indicates the areas of population density in the center and southeast areas of the base. The base airfield is in the northwest area of the base. Numerous base facilities, buildings, ranges, and training areas are located on this site.

\section{A.1.4 Screening Criteria Overview}

Table A.2 shows a screening criteria summary bar, or "dashboard" chart, for the site area provides a quick look at what siting issues may exist for the site. The criteria that are not met within the site area indicated.

\footnotetext{
${ }^{11}$ http://www.military.com/base-guide/beale-air-force-base/base-directory
} 


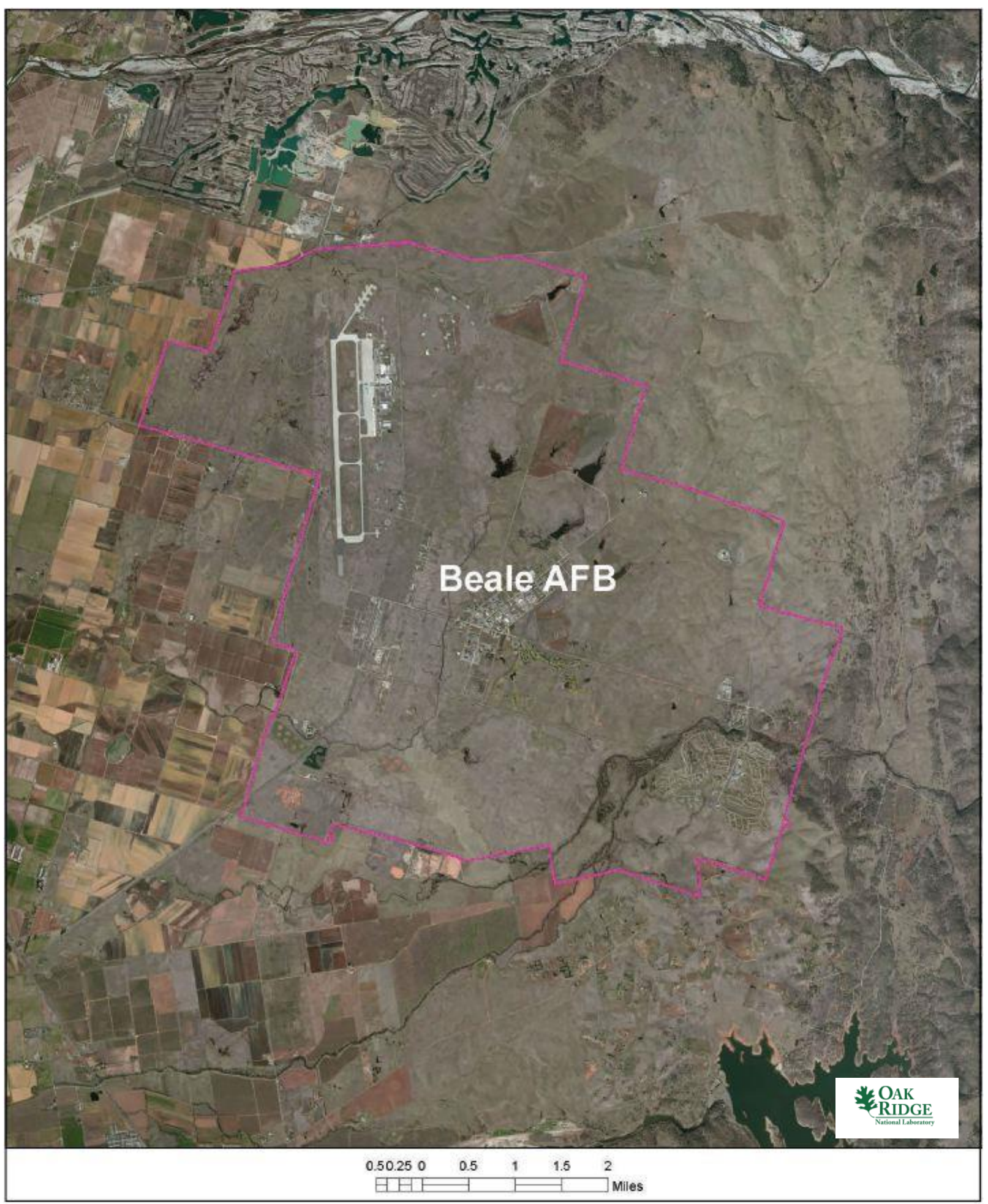

Fig. A.2. Satellite view of Beale Air Force Base area. 
Table A.2. Beale Air Force Base siting criteria summary

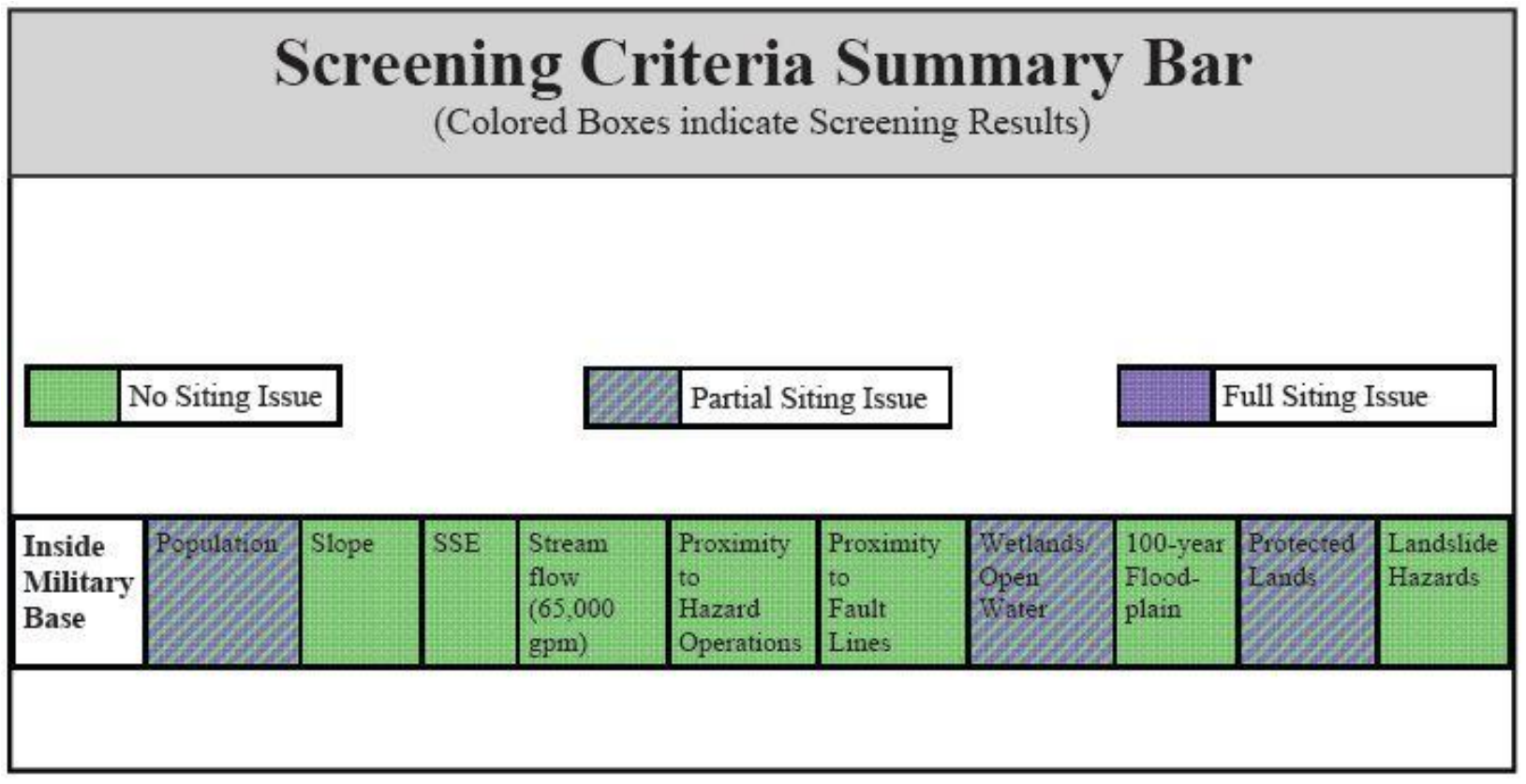

\begin{tabular}{|l|l|}
\hline \multicolumn{2}{|c|}{ Screening Criteria Table } \\
\hline \multicolumn{1}{|c|}{ Criteria } & Value \\
\hline Population Density within 10 miles (people/square mile) & $>500$ \\
\hline Slope & $>18 \%$ \\
\hline Safe shutdown earthquake (ground acceleration) & $>0.5$ \\
\hline Streamflow/cooling water make-up (gpm) & $<65,000$ \\
\hline Proximity to hazardous operations - buffer (mile) & Depends on hazardous operation ${ }^{1}$ \\
\hline Proximity to fault lines - buffer (mile) & Depends on length of fault \\
\hline Wetlands/Open Water & - \\
\hline 100-year floodplain & - \\
\hline Protected lands & - \\
\hline Landslide hazard (moderate and high) & - \\
\hline
\end{tabular}

${ }^{1}$ Hazardous facilities (airports- 5 miles and oil refineries-1 mile) 


\section{A.1.5 Composite Map and Individual Siting Issue Maps}

A composite map of SMR siting challenges to the Beale Air Force Base is shown in Fig. A.3. Siting challenges are predominantly in the central and southeast areas of the base. Following this map are maps of the individual SMR siting criteria based on selected input values.

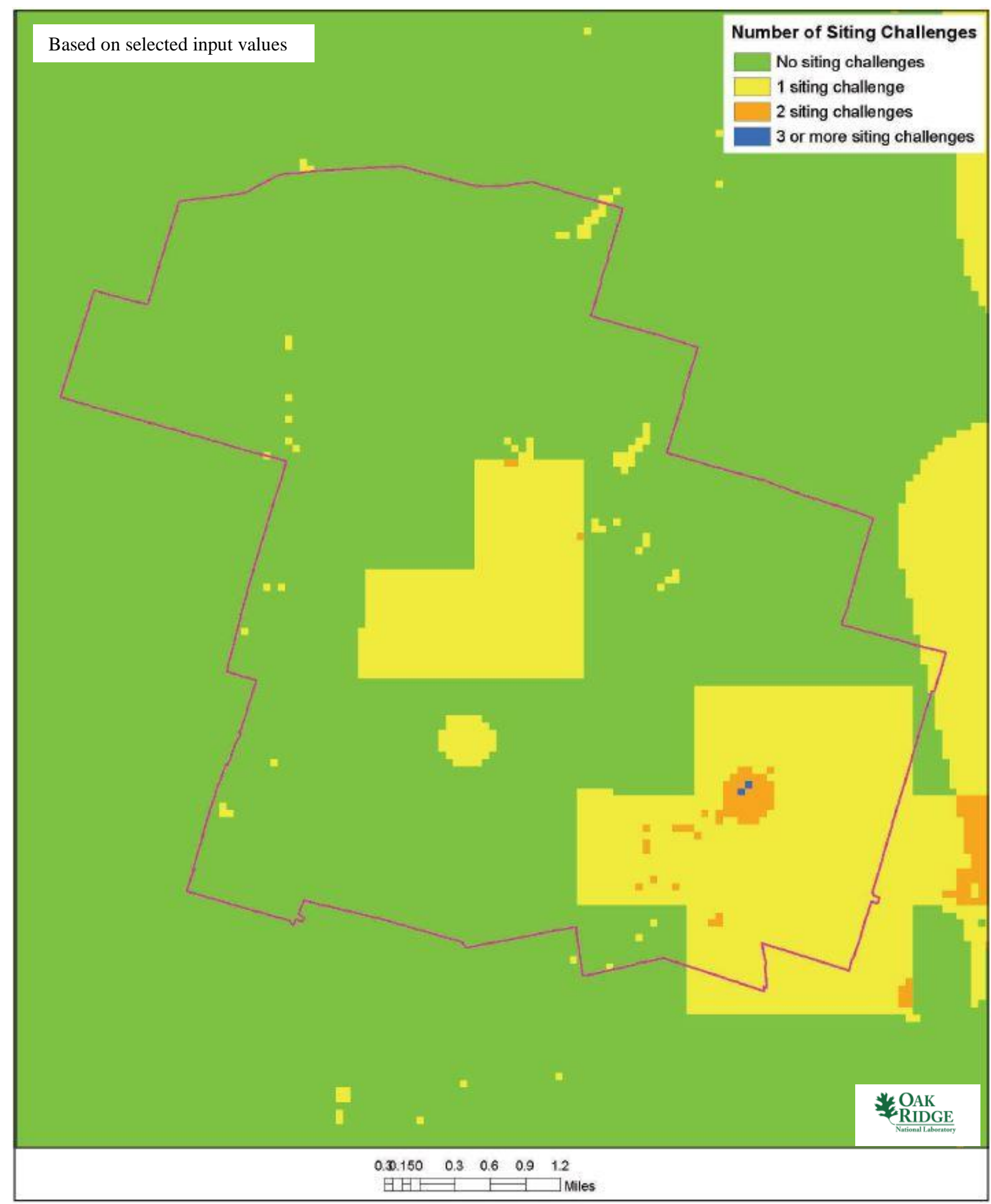

Fig. A.3. Beale Air Force Base composite map. 

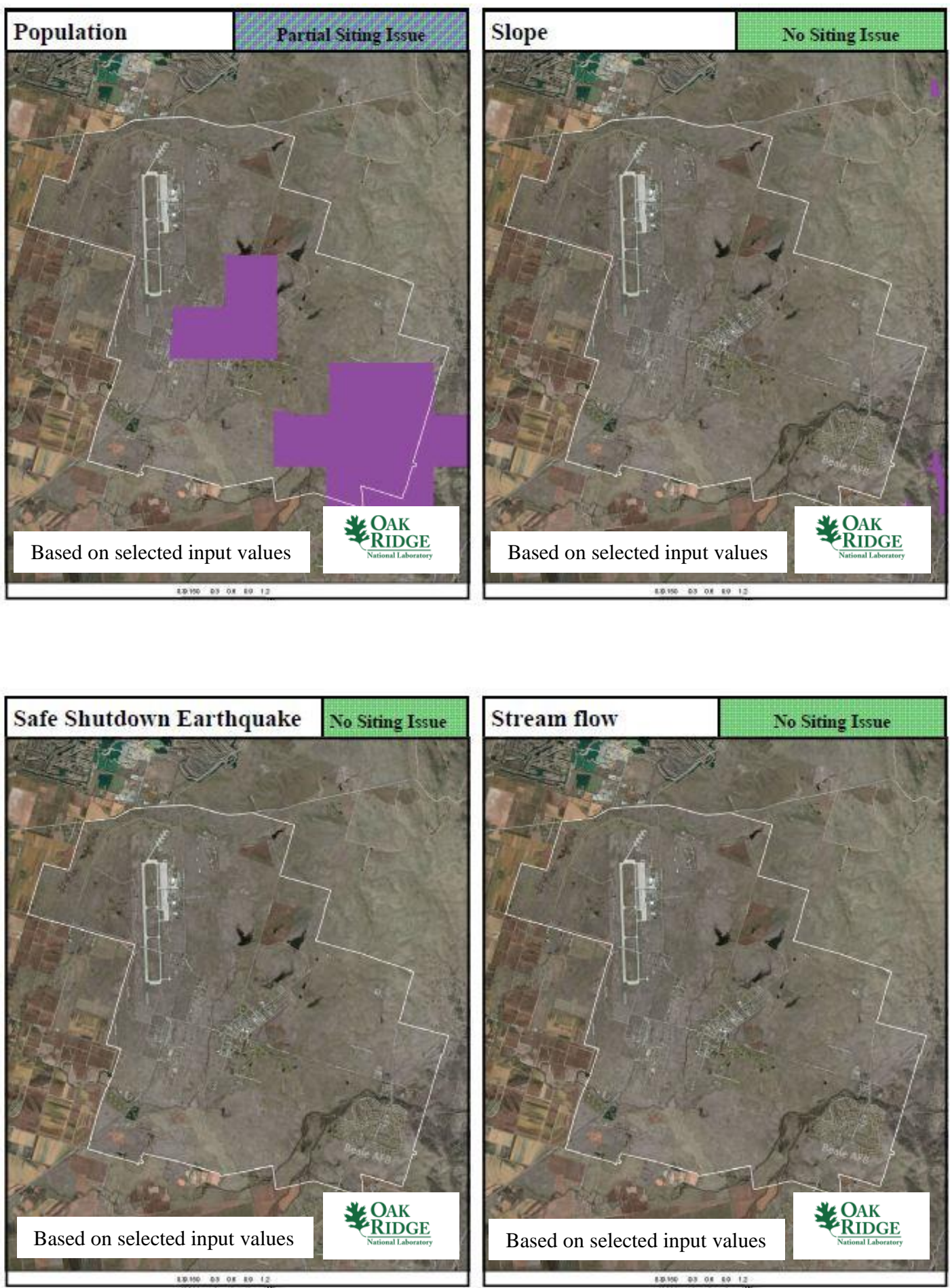

Beale Air Force Base 

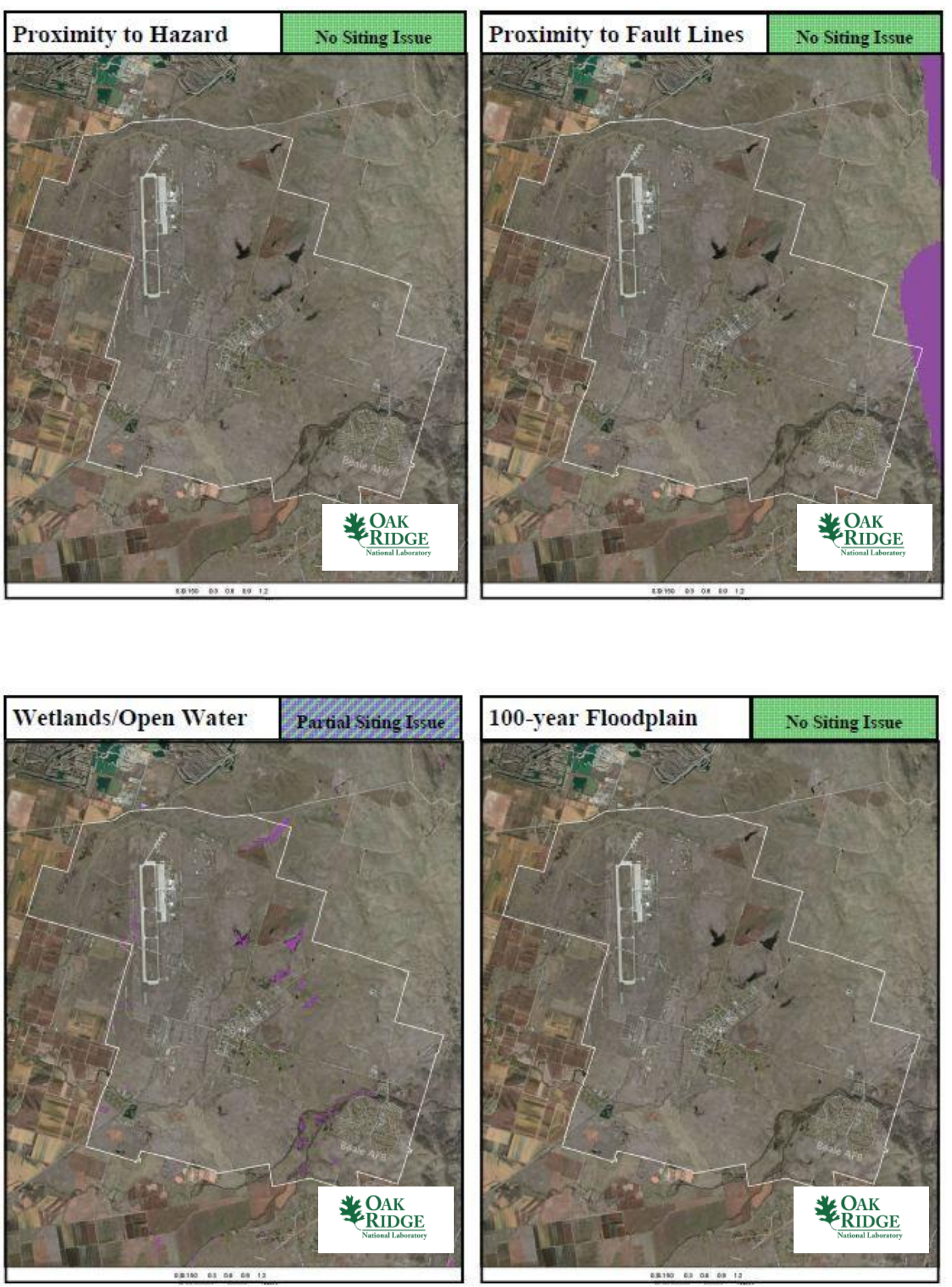

Beale Air Force Base 

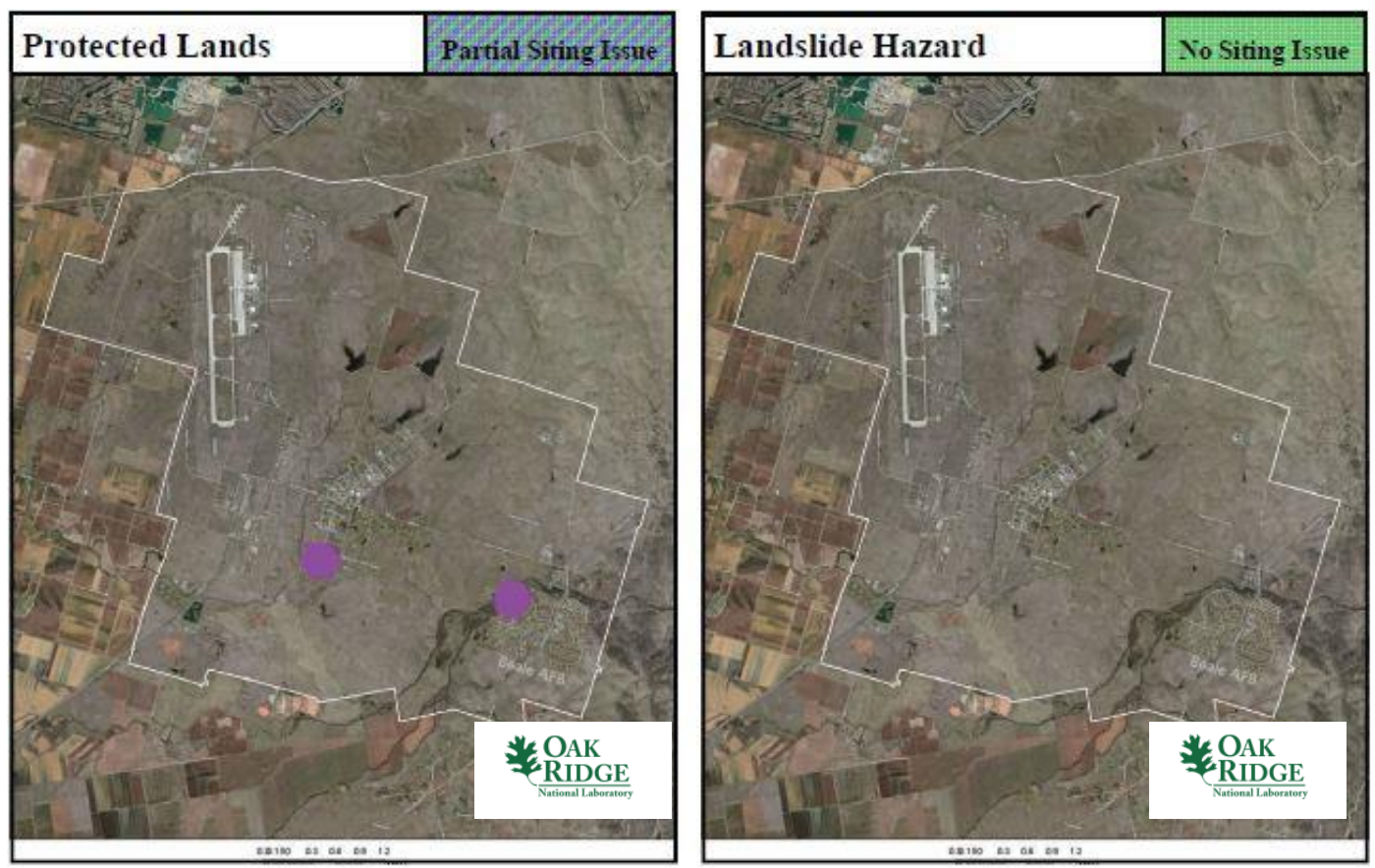

Beale Air Force Base

\section{A.1.6 Site Evaluation}

Beale Air Force Base is a large, federally controlled site. A well-trained, well-armed security force is available. Many of the activities and missions carried out on this base are high technology, mechanized endeavors. Personnel living or working on the base would have considerable familiarity with the technology- and security-related operations associated with nuclear power plant operation. Power demands on the base associated with the military missions and local infrastructure for current residents and workers would possibly be less than for more populous bases but still potentially suitable for smaller SMRs.

As shown in Sects. A.1.4 and A.1.5, approximately $75 \%$ of the 21,000 -acre site meets multiple conventional standards for consideration of siting an SMR on the base facility. ${ }^{1}$ However, the clearly visible airfield in the satellite imagery was not automatically removed from consideration due to the special circumstances of this OR-SAGE application. The area around a commercial airport is typically buffered from siting consideration by OR-SAGE to a distance of 5 miles. Military airfields are not considered separately, because military facilities are already an SMR SSEC exclusion factor for commercial SMR siting. As a result, the airfield area on the base must be considered separately. Excluding land from consideration to a 5-mile radius from the center of the airfield essentially excludes all but a few hundred acres of Beale Air Force Base for suitability for siting an SMR. Population excludes the area furthest away from the runway.

However, the airport runway runs almost north and south on the northwestern edge of the site. If an off-axis relaxation in the exclusion distance requirement to the airfield to 2 miles instead of 5 miles is permitted, then approximately $50 \%$ of the site would be potentially suitable for siting an SMR. If a 3-mile exclusion distance is applied, then approximately $25 \%$ of the site would be potentially suitable for siting an SMR. Note that the airport buffer criterion is an avoidance recommendation. This along with the underground construction of a typical SMR may support a relaxation of the airport avoidance buffer distance. 
Nuclear power restrictions in place in California were not considered for this study since the siting tool is based on site characteristics and does not incorporate state or local policy, land use, or zoning issues. The site meets current NRC RG 4.7 recommendations for population density without additional consideration for relaxed SMR population siting requirements based on reduced source term.

Unless a relaxation in the avoidance area associated with the on-site airfield is permitted, this site is not a likely candidate for consideration of siting an SMR. 


$$
\text { A-10 }
$$




\section{A.2 EGLIN AIR FORCE BASE}

\section{A.2.1 Location Detail}

As shown in Fig. A.4, Eglin Air Force Base is located in the western Florida panhandle. The base covers approximately 420,000 acres ${ }^{6}$ (about 650 square miles) in the Santa Rosa, Okaloosa, and Walton Counties of Florida, generally located north, east, and west of the town of Niceville, Florida. Nearby towns include Niceville a few miles south of the center of the base. Destin is approximately 5 miles to the south; Pensacola, approximately 20 miles west; Crestview, approximately 5 miles north; and Freeport, approximately 2 miles southeast of the base's perimeter.

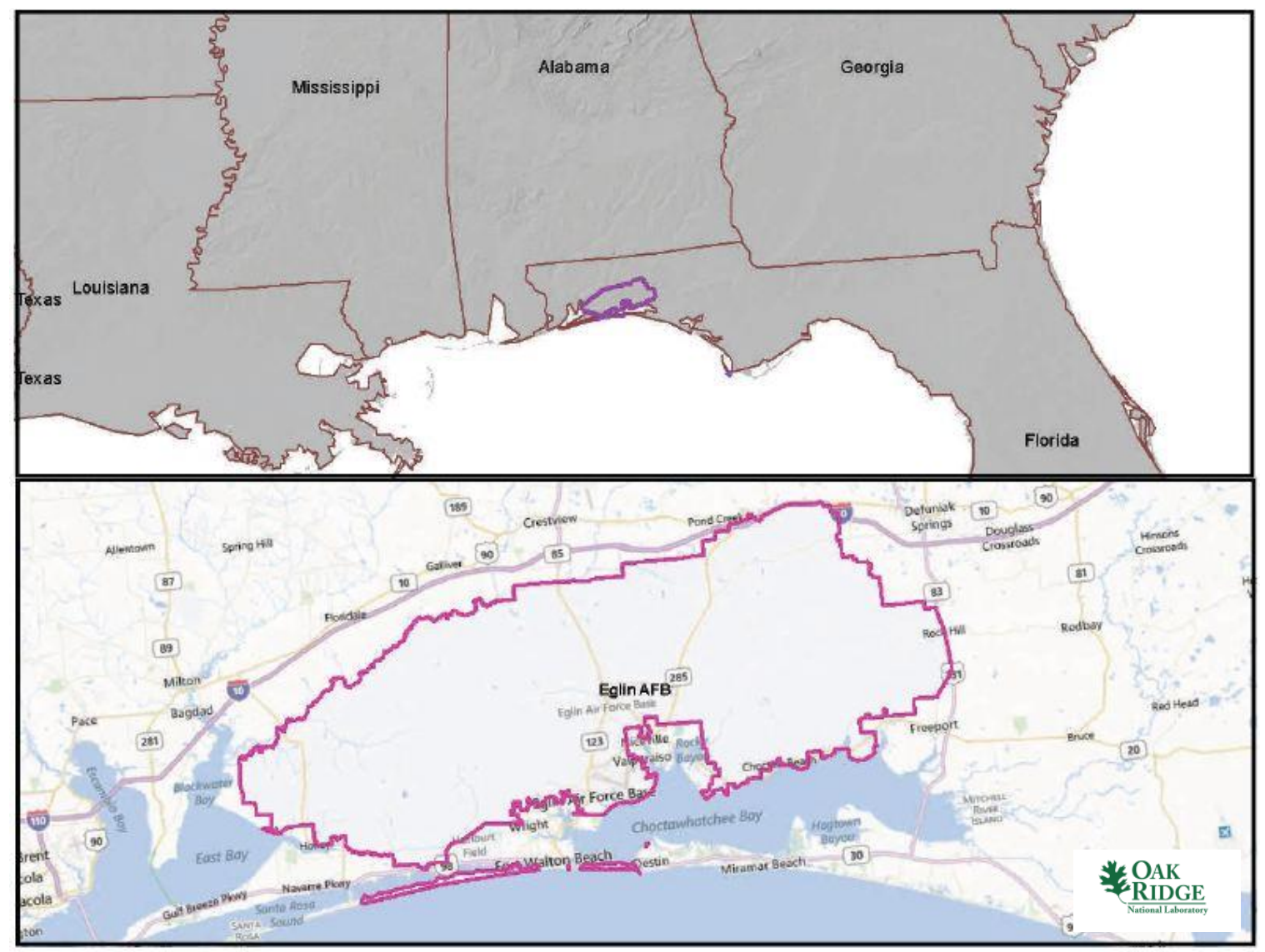

Fig. A.4. Eglin Air Force Base.

\section{A.2.2 Site Description and Status}

Eglin Air Force Base hosts the 33rd Fighter Wing; 53rd Wing; the Air Force Research Laboratory Munitions Directorate; 6th Ranger Training Battalion; Joint Deployable Analysis Team; Defense Threat Reduction Agency Research and Development Counter Weapons of Mass Destruction, Weapons and Capabilities Division; 96th Test Wing; Armament Directorate; 919th Special Operations Wing; 20th Space Squadron; an Air Force Operational Test and Evaluation Center detachment; Naval School Explosive Ordnance Disposal command; 728th Air Control Squadron; 7th Special Forces Group; and others. Descriptions of the military units and base history are readily available on the Internet. ${ }^{12,13}$

\footnotetext{
12 http://www.eglin.af.mil/

${ }^{13} \mathrm{http}: / /$ en.wikipedia.org/wiki/Eglin_Air_Force_Base
} 
Services and resources are available on the base for military staff, families, employees, and services contractors similar to a small town. As noted in the Eglin Air Force Base Newcomer's Guide, ${ }^{14}$ lodging and housing, various shopping facilities, hospital, financial service institutions, places of worship, restaurants, library, elementary school, cultural amenities, and many other goods and services typical of a small city or town are located on the base.

Eglin Air Force Base covers approximately 650 square miles. Approximately $50 \%$ of the base area is forested. The permanent population surrounding the base within 1 mile of the perimeter is approximately 337,000. Approximately, 8,000 people reside on the base in about 2,300 households and about 15,000 work there. ${ }^{14}$ As a result of Base Realignment and Closure (BRAC) Commission actions in 2005 affecting other bases, overall base population at Eglin AFB may grow to 38,000 in the next few years, and Eglin may see military construction totaling $\$ 732$ million over this time period.

As noted in Table A.3, the nearest major fault line based on USGS data is noted to be 682 miles northwest in Oklahoma. The maximum safe shutdown earthquake for the site is below $0.3 \mathrm{~g}$ peak ground acceleration. Greater than 500,000 gpm of cooling water makeup is available from the Yellow River near the northwest perimeter of the base.

Table A.3. Eglin Air Force Base site statistics

\begin{tabular}{|l|l|l|l|}
\hline $\begin{array}{l}\text { Population } \\
\text { Population Within }\end{array}$ & \multicolumn{2}{l|}{$\begin{array}{l}\text { Utility } \\
\text { Distance to Grid Capacity }\end{array}$} \\
\hline $0.5 \mathrm{mi}$ of Site Boundary & $\sim 260,000$ & $>400 \mathrm{MWe}$ & $\sim 0.1 \mathrm{mi}$ \\
\hline $1 \mathrm{mi}$ of Site Boundary & $\sim 337,500$ & $>800 \mathrm{MWe}$ & $\sim 66 \mathrm{mi}$ \\
\hline $5 \mathrm{mi}$ of Site Boundary & $\sim 600,000$ & $>1600 \mathrm{MWe}$ & $\sim 67 \mathrm{mi}$ \\
\hline 10 mi of Site Boundary & $\sim 870,000$ & $>3200 \mathrm{MWe}$ & $\sim 184 \mathrm{mi}$ \\
\hline Nearest City with Population & Distance to Cooling Water \\
\hline$>10,000$ & & $>50,000$ gpm & $\sim 0.1 \mathrm{mi}$ (Yellow River) \\
\hline$>50,000$ & Niceville, FL & $>100,000$ gpm & $\sim 0.1 \mathrm{mi}$ (Yellow River) \\
\hline$>100,000$ & Pensacola, FL & $>200,000$ gpm & $\sim 0.1 \mathrm{mi}$ (Yellow River) \\
\hline$>500,000$ & Mobile, AL & $>500,000$ gpm & $\sim 0.1 \mathrm{mi}$ (Yellow River) \\
\hline Geotechnical & Jacksonville, FL & Accessibility & \multicolumn{2}{l|}{} \\
\hline Max Earthquake Acceleration & $<0.3 \mathrm{~g}$ & Distance to Major Roadway & $\sim 0.1 \mathrm{mi}$ (Interstate 10) \\
\hline Max Slope & $\sim 15 \%$ & Distance to Water Transport & $\sim 0.1 \mathrm{mi}$ (Atlantic Spine) \\
\hline Nearest Fault Line & $\sim 682$ mi (Oklahoma) & Distance to Rail Transport & $\sim 0.1 \mathrm{mi}$ (CSXT) \\
\hline Nearest Hazard Site & $\sim$ On Site (Eglin AFB) & Distance to Airport & $\sim$ On Site (Eglin AFB) \\
\hline
\end{tabular}

\section{A.2.3 Aerial Imagery}

The aerial imagery in Fig. A.5 indicates the areas of population density in the south-central area of the base, the adjacent commercial airport, a highway crossing the base from north to south near the western boundary of the base, two highways bisecting the base from north to south near the center of the base and Interstate 10 traversing from east to west just north of the base perimeter. The Choctawhatchee Bay forms a large part of the southeast perimeter of the base. The East Bay and Blackwater Bays are near the western end of the base. The Yellow River forms the northwest perimeter. Various airfields, ranges, structures, and training areas are located across this large base.

\footnotetext{
${ }^{14} \mathrm{http}: / / w w w . E g l i n G u i d e O n l i n e . c o m$
} 


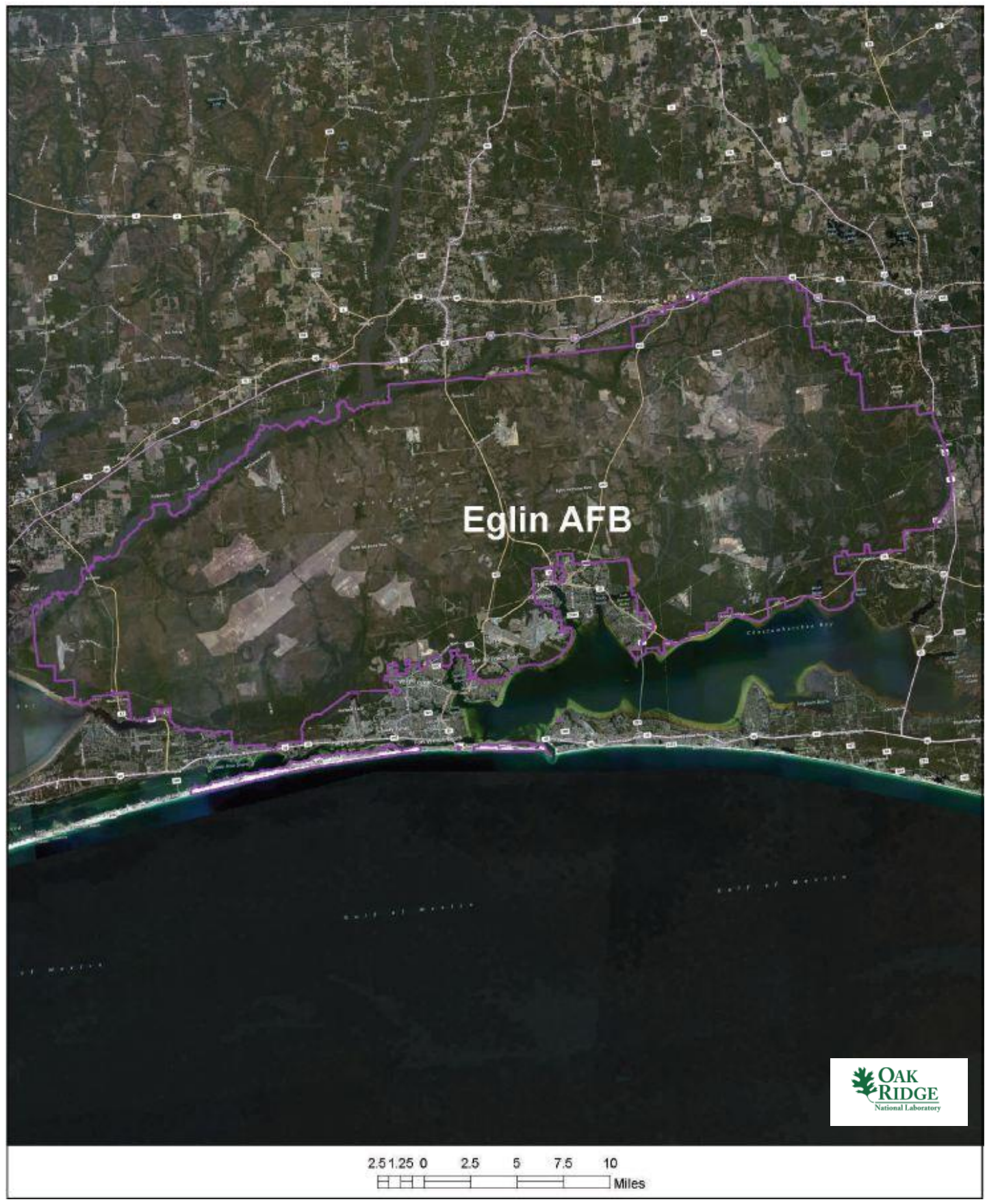

Fig. A.5. Satellite view of Eglin Air Force Base area.

\section{A.2.4 Screening Criteria Overview}

Table A.4 shows a screening criteria summary bar, or "dashboard" chart, for the site area provides a quick look at what siting issues may exist for the site. The criteria that are not met within the site area indicated. 
Table A.4. Eglin Air Force Base siting criteria summary

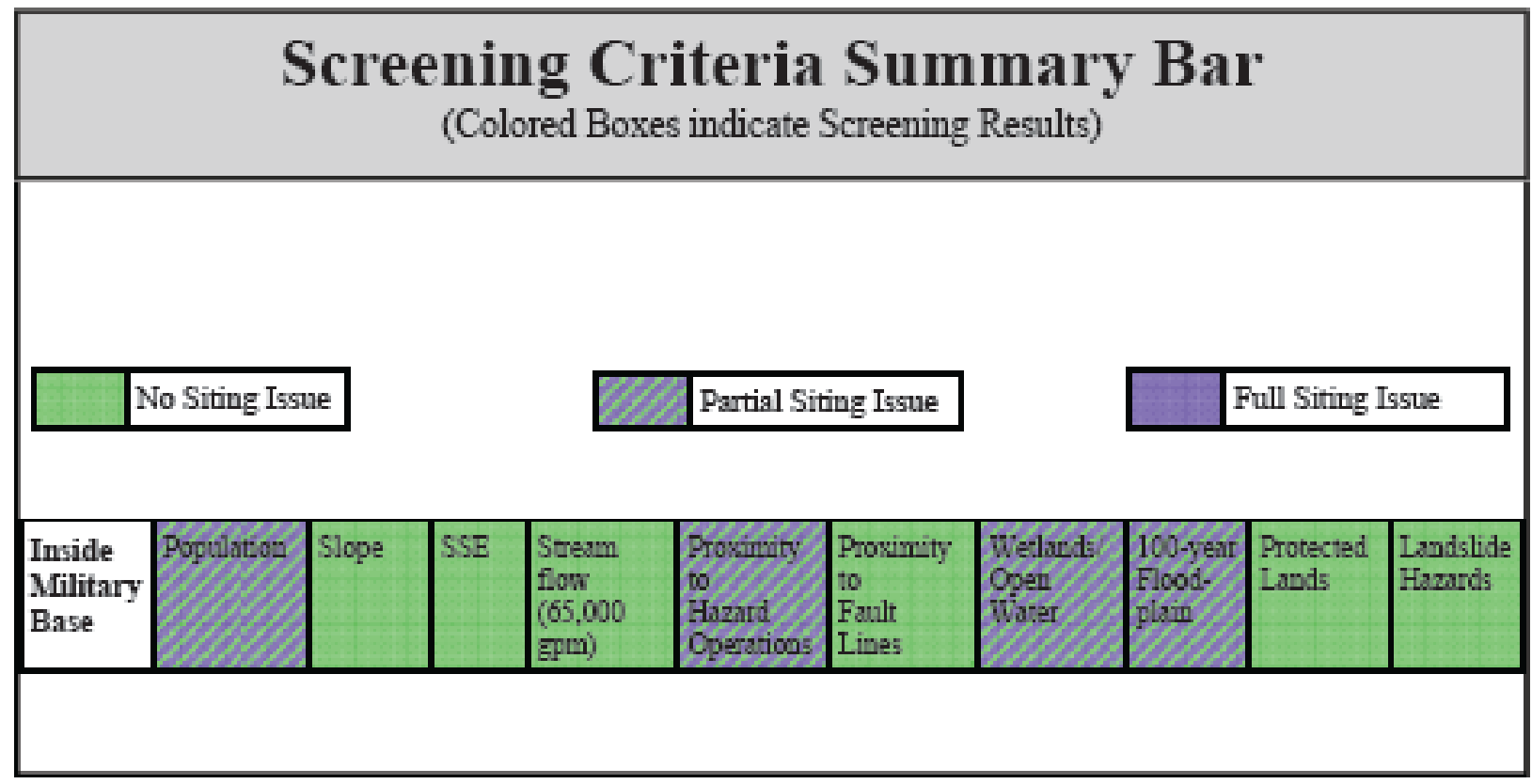

\begin{tabular}{|l|c|}
\hline \multicolumn{2}{|c|}{ Screening Criteria Table } \\
\hline \multicolumn{1}{|c|}{ Criteria } & Value \\
\hline Population Density within 10 miles (people/square mile) & $>500$ \\
\hline Slope & $>18 \%$ \\
\hline Safe sluutdown earthquake (ground acceleration) & $>0.5$ \\
\hline Streamflow/cooling water make-up (gpm) & $<65,000$ \\
\hline Proximity to hazardous operations - buffer (mile) & Depends on hazardous operation \\
\hline Proximity to fault lines - buffer (mile) & Depends on length of fault \\
\hline Wetlands/Open Water & - \\
\hline 100 -year floodplain & \\
\hline Protected lands & \\
\hline Landslide hazard (moderate and high) & - \\
\hline
\end{tabular}

${ }^{1}$ Hazardous facilities (airports-5 miles and oil refineries-1 mile) 


\section{A.2.5 Composite Map and Individual Siting Issue Maps}

A composite map of SMR siting challenges to the Eglin Air Force Base is shown in Fig. A.6. Siting issues are predominantly located in the south central part of the site. Following this map are maps of the individual SMR siting criteria based on selected input values.

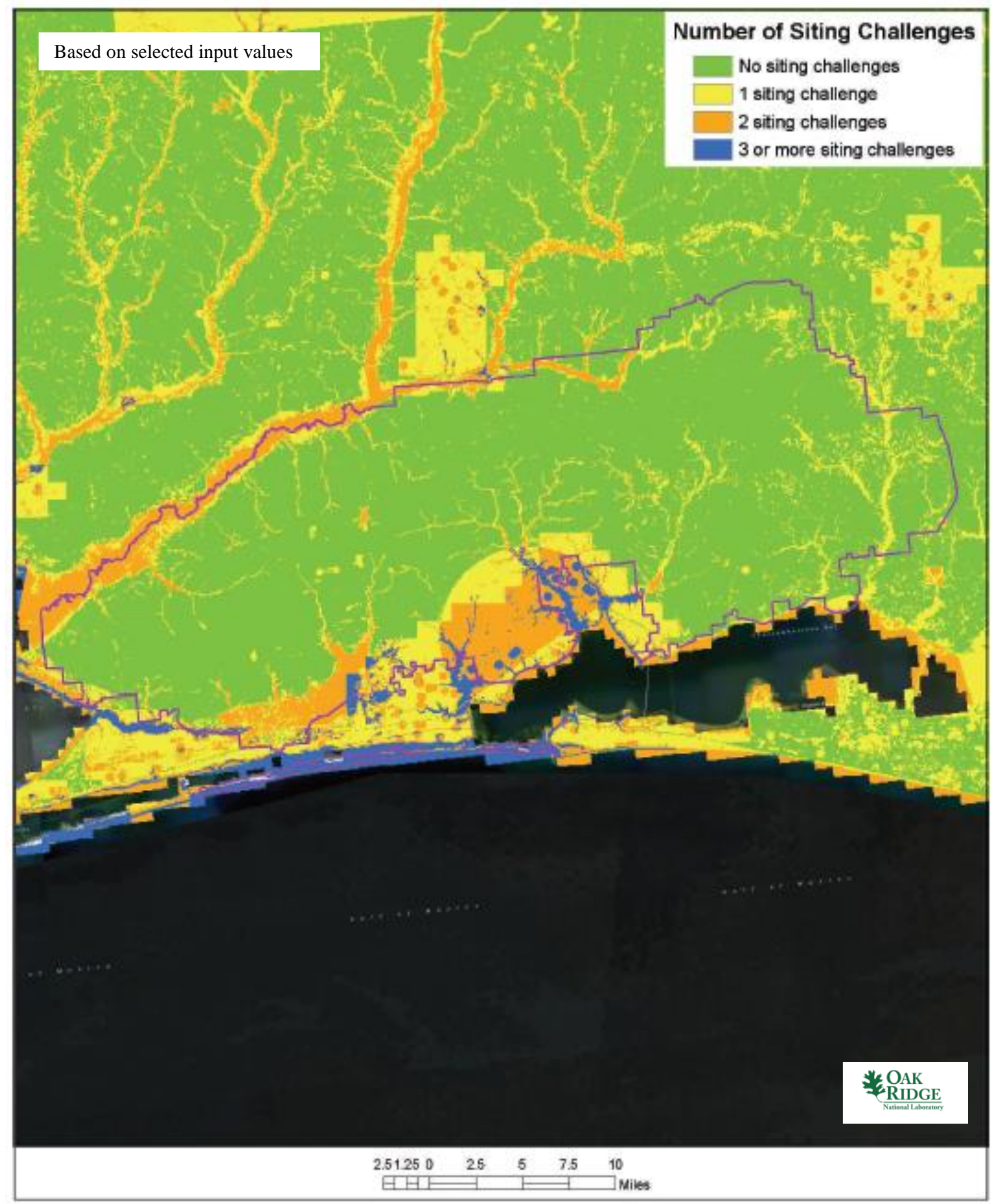

Fig. A.6. Eglin Air Force Base composite map. 

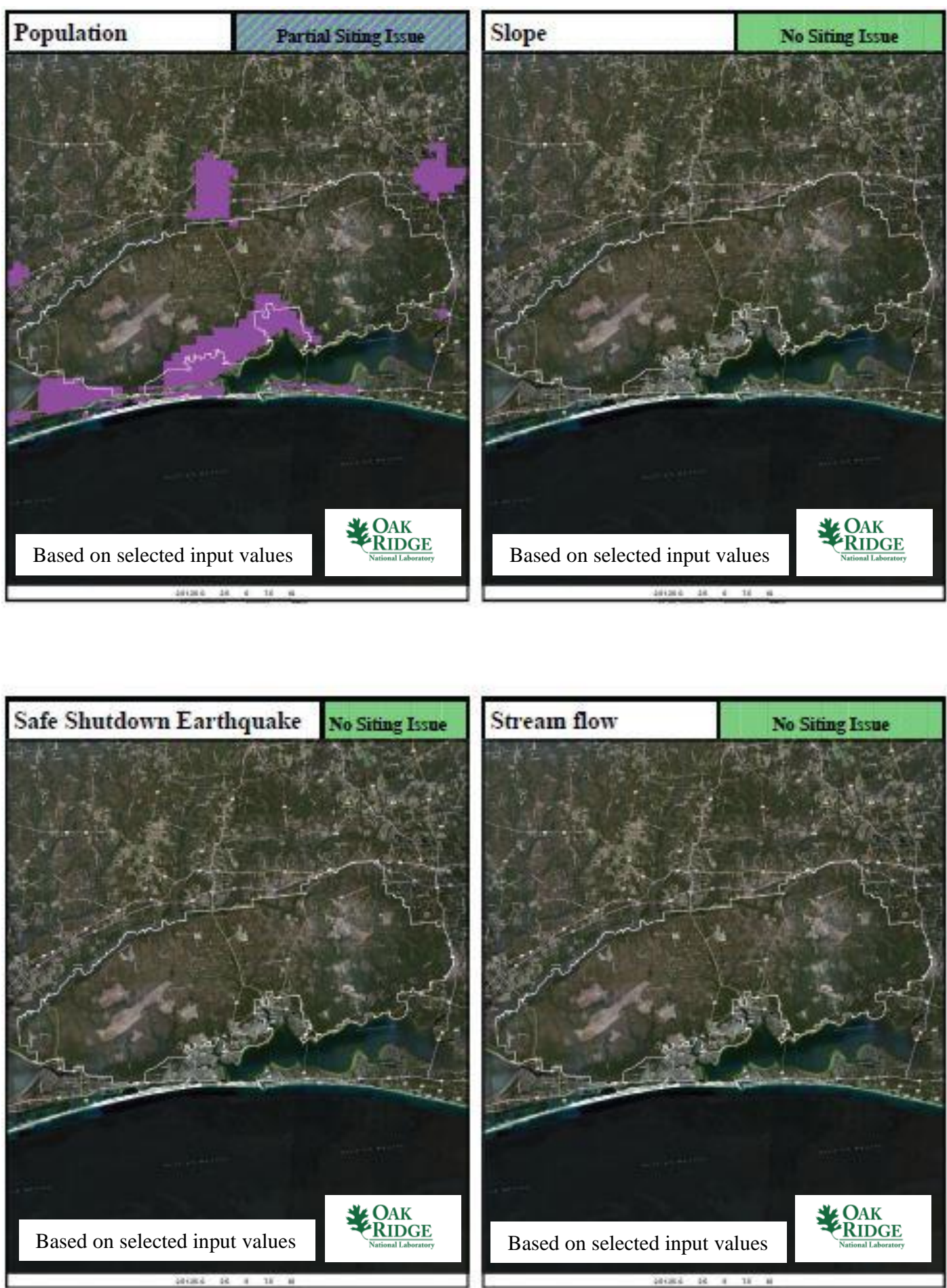

Eglin Air Force Base 

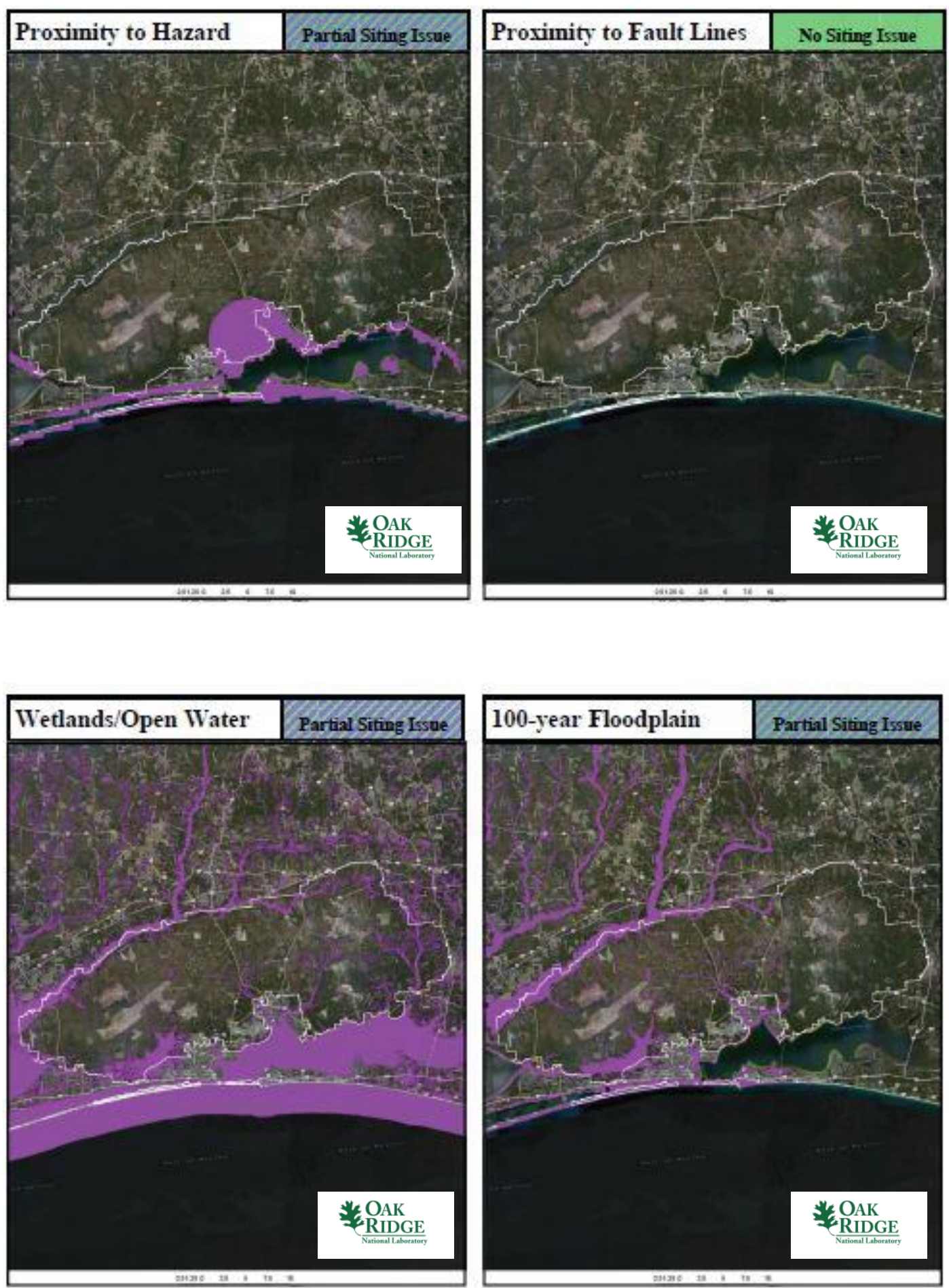

Eglin Air Force Base 

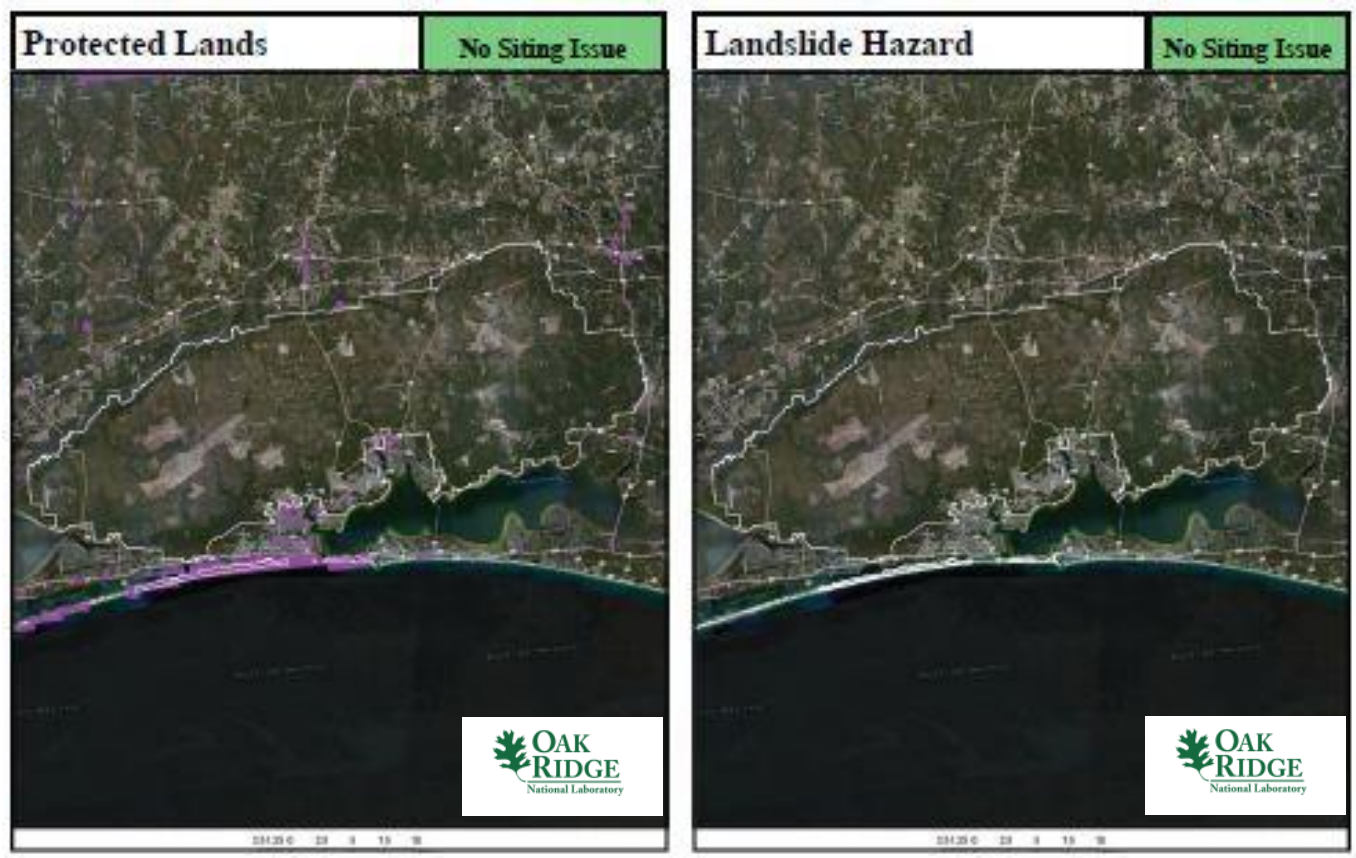

Eglin Air Force Base

\section{A.2.6 Site Evaluation}

Eglin Air Force Base is a large, federally controlled site. A well-trained, well-armed security force is available. Many of the activities and missions carried out on this base are state-of-the-art, high technology endeavors. Personnel living or working on the base would have considerable familiarity with the technology-and security-related operations associated with nuclear power plant operation as well as the necessary construction-related activities. Power demands on the base associated with the military missions and local infrastructure for current residents and workers would also be considerable and feasible for a site-located SMR. Growth in electrical demand and energy growth will occur at Eglin Air Force Base due to missions, military staff, residents, employees, and construction coming there as a result of the BRAC-related consolidations and closures of other bases.

As shown in Sects. A.2.4 and A.2.5, the Eglin Air Force Base site has partial site issues with wetlands/open water and the 100-year floodplain. ${ }^{1}$ This impacts areas across the site. Approximately, $71 \%$ of the 420,000 -acre site meets multiple conventional standards for consideration of siting an SMR on the base facility. However, multiple clearly visible airfields in the satellite imagery were not automatically removed from consideration due to the special circumstances of this OR-SAGE application. The area around a commercial airport is typically buffered from siting consideration by OR-SAGE to a distance of 5 miles. Military airfields are not considered separately, because military facilities are already an SMR SSEC exclusion factor for commercial SMR siting. As a result, the airfield areas on the base must be considered separately. Excluding land from consideration to a 5-mile radius from the center of the airfield essentially excludes an additional $40 \%$ of Eglin Air Force Base for suitability for siting an SMR. After consideration of runways, approximately 30\% of Eglin Air Force Base meets multiple conventional standards for consideration of siting an SMR on the base facility.

The site meets current NRC RG 4.7 recommendations for population density without additional consideration for relaxed SMR population siting requirements based on reduced source term. This site should be classified as favorable for siting an SMR. 


\section{A.3 FORT BENNING}

\section{A.3.1 Location Detail}

As shown in Fig. A.7, Fort Benning is located on about 165,000 acres ${ }^{6}$ (about 260 square miles) on the Chattahoochee River border between Georgia and Alabama, approximately the north-south center of each state. Over $90 \%$ of the base area is in Georgia. The city of Columbus, Georgia, is at the northwest of the base border. Fort Benning is home to the US Army Armor School, US Army Infantry School, Western Hemisphere Institute for Security Cooperation, 75th Ranger Regiment, 3rd Brigade-3rd Infantry Division, and many other corps, units, institutes, and agencies. Interstate 185 enters Columbus, Georgia, and the base area from the north. Highway 27 bisects the base from northwest to southeast. Numerous rivers and streams cross the base.

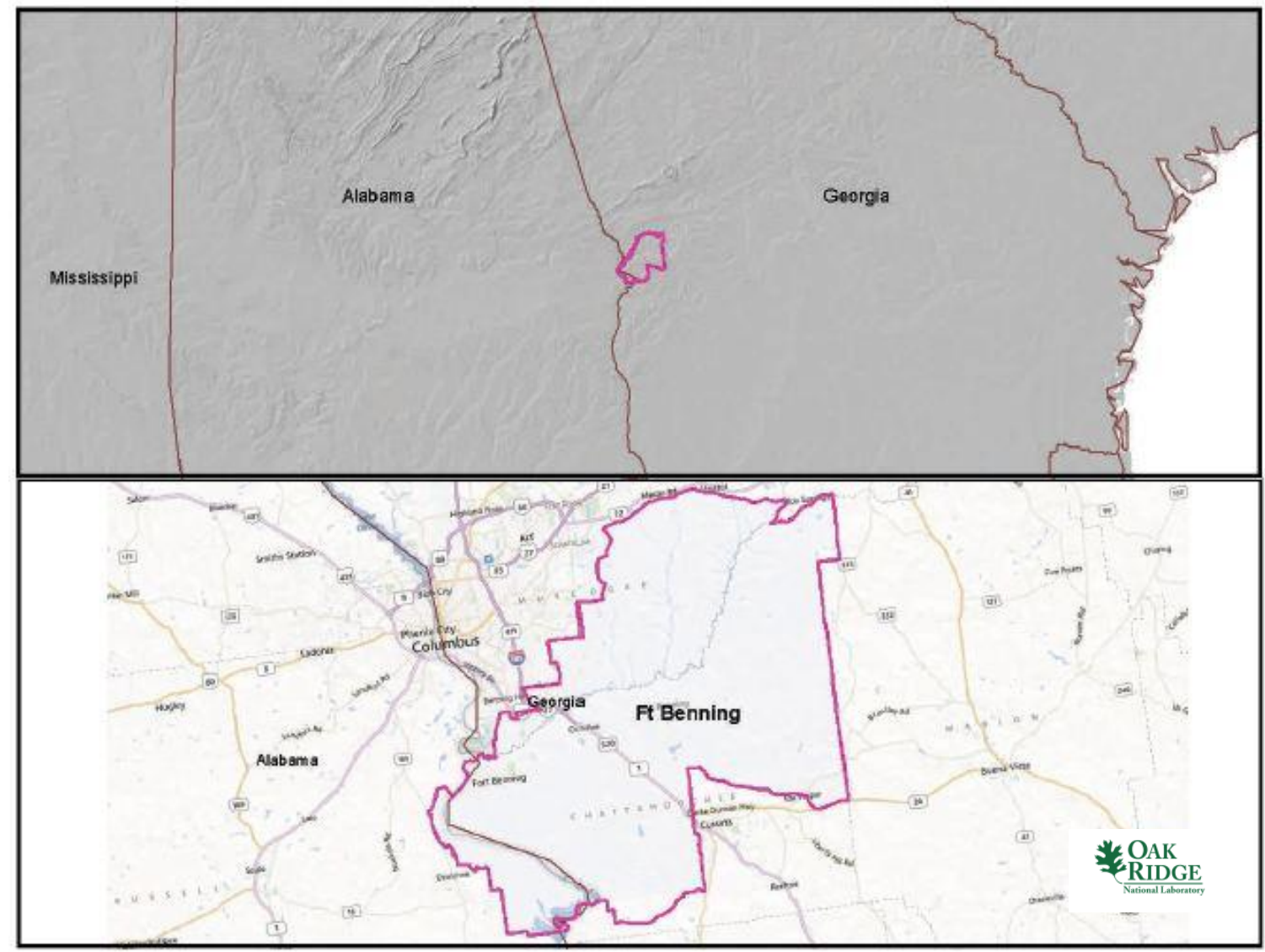

Fig. A.7. Fort Benning.

\section{A.3.2 Site Description and Status}

The US Army Armor School, US Army Infantry School, Western Hemisphere Institute for Security Cooperation, 75th Ranger Regiment, 3rd Brigade-3rd Infantry Division, and many other corps, units, institutes, and agencies are located at Fort Benning. 
Approximately, 115,000 soldiers train at Fort Benning each year. About 130,000 soldiers, employees, families, and contractors are on-site at any given time. ${ }^{15}$ Descriptions of the installation, missions, and base history are readily available on the Internet. ${ }^{16,17}$

Services and resources are available on the base for military staff, families, employees, and services contractors similar to a small town, including lodging and housing, schools, hospital, various shopping facilities, restaurants, library, cultural and recreational amenities, and many other goods and services. ${ }^{1}$

As noted in Table A.5, the nearest major fault line based on USGS data is noted to be 740 miles west in Oklahoma. The maximum safe shutdown earthquake for the site is below $0.3 \mathrm{~g}$ peak ground acceleration. The maximum slope on the site is about $21 \%$. Greater than 500,000 gpm of cooling water makeup is available from the Chattahoochee River at the west side of the base. Major highways, water transport, and rail transport are nearby.

Table A.5. Fort Benning site statistics

\begin{tabular}{|c|c|c|c|}
\hline \multicolumn{2}{|l|}{$\begin{array}{l}\text { Population } \\
\text { Population Within }\end{array}$} & \multicolumn{2}{|l|}{$\begin{array}{l}\text { Utility } \\
\text { Distance to Grid Capacity }\end{array}$} \\
\hline $0.5 \mathrm{mi}$ of Site Boundary & $\sim 134,000$ & $>400 \mathrm{MWe}$ & $\sim 2.0 \mathrm{mi}$ \\
\hline $1 \mathrm{mi}$ of Site Boundary & $\sim 158,000$ & $>800 \mathrm{MWe}$ & $\sim 5.0 \mathrm{mi}$ \\
\hline $5 \mathrm{mi}$ of Site Boundary & $\sim 400,000$ & $>1600 \mathrm{MWe}$ & $\sim 0.1 \mathrm{mi}$ \\
\hline $10 \mathrm{mi}$ of Site Boundary & $\sim 611,000$ & $>3200 \mathrm{MWe}$ & $\sim 54 \mathrm{mi}$ \\
\hline \multicolumn{2}{|c|}{ Nearest City with Population } & \multicolumn{2}{|c|}{ Distance to Cooling Water } \\
\hline$>10,000$ & Phenix City, AL & $>50,000 \mathrm{gpm}$ & $\sim 14$ mi (Mulberry Creek) \\
\hline$>50,000$ & Albany, GA & $>100,000 \mathrm{gpm}$ & $\sim 14$ mi (Mulberry Creek) \\
\hline$>100,000$ & Columbus, GA & $>200,000 \mathrm{gpm}$ & $\begin{array}{c}\sim 0.1 \mathrm{mi} \text { (Chattahoochee } \\
\text { River) }\end{array}$ \\
\hline$>500,000$ & Jacksonville, FL & $>500,000 \mathrm{gpm}$ & $\begin{array}{c}\sim 0.1 \mathrm{mi} \text { (Chattahoochee } \\
\text { River) }\end{array}$ \\
\hline \multicolumn{2}{|l|}{ Geotechnical } & \multicolumn{2}{|l|}{ Accessibility } \\
\hline Max Earthquake Acceleration & $<0.3 \mathrm{~g}$ & Distance to Major Roadway & $\sim 27 \mathrm{mi}$ (Interstate 85 ) \\
\hline Max Slope & $\sim 21 \%$ & Distance to Water Transport & $\sim 0.1 \mathrm{mi}$ (Pacific Deep) \\
\hline Nearest Fault Line & $\sim 741 \mathrm{mi}$ (Oklahoma) & Distance to Rail Transport & $\sim 0.1 \mathrm{mi}(\mathrm{NS})$ \\
\hline Nearest Hazard Site & $\begin{array}{l}\sim 5 \mathrm{mi} \text { (Airport- } \\
\quad \text { Columbus Metropolitan) }\end{array}$ & Distance to Airport & $\begin{array}{c}5 \mathrm{mi} \text { (Columbus } \\
\text { Metropilitan) }\end{array}$ \\
\hline
\end{tabular}

\section{A.3.3 Aerial Imagery}

The aerial imagery in Fig. A.8 indicates the areas of population density in the northwest area of the base. Numerous base facilities, buildings, ranges, and training areas are located on this large site.

\footnotetext{
${ }^{15} \mathrm{http} / / /$ virtual.mybaseguide.com/publications/g30/fort-benning/\#page4

${ }^{16} \mathrm{http}: / /$ www.Benning.army.mil/

${ }^{17} \mathrm{http} / / /$ en.wikipedia.org/wiki/Fort_Benning
} 


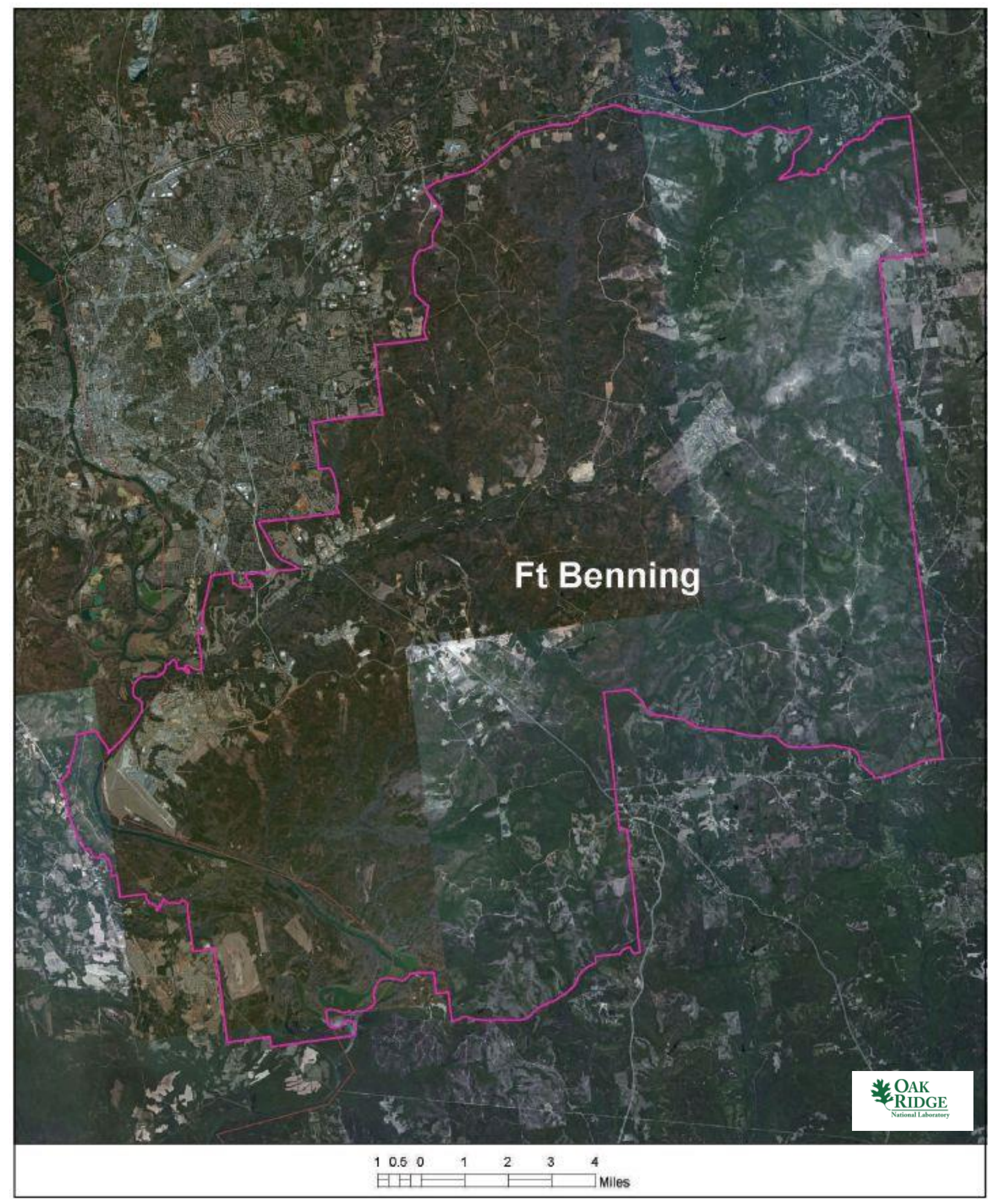

Fig. A.8. Satellite view of Fort Benning area. 


\section{A.3.4 Screening Criteria Overview}

Table A.6 shows a screening criteria summary bar, or "dashboard" chart, for the site area provides a quick look at what siting issues may exist for the site. The criteria that are not met within the site area indicated.

Table A.6. Fort Benning siting criteria summary

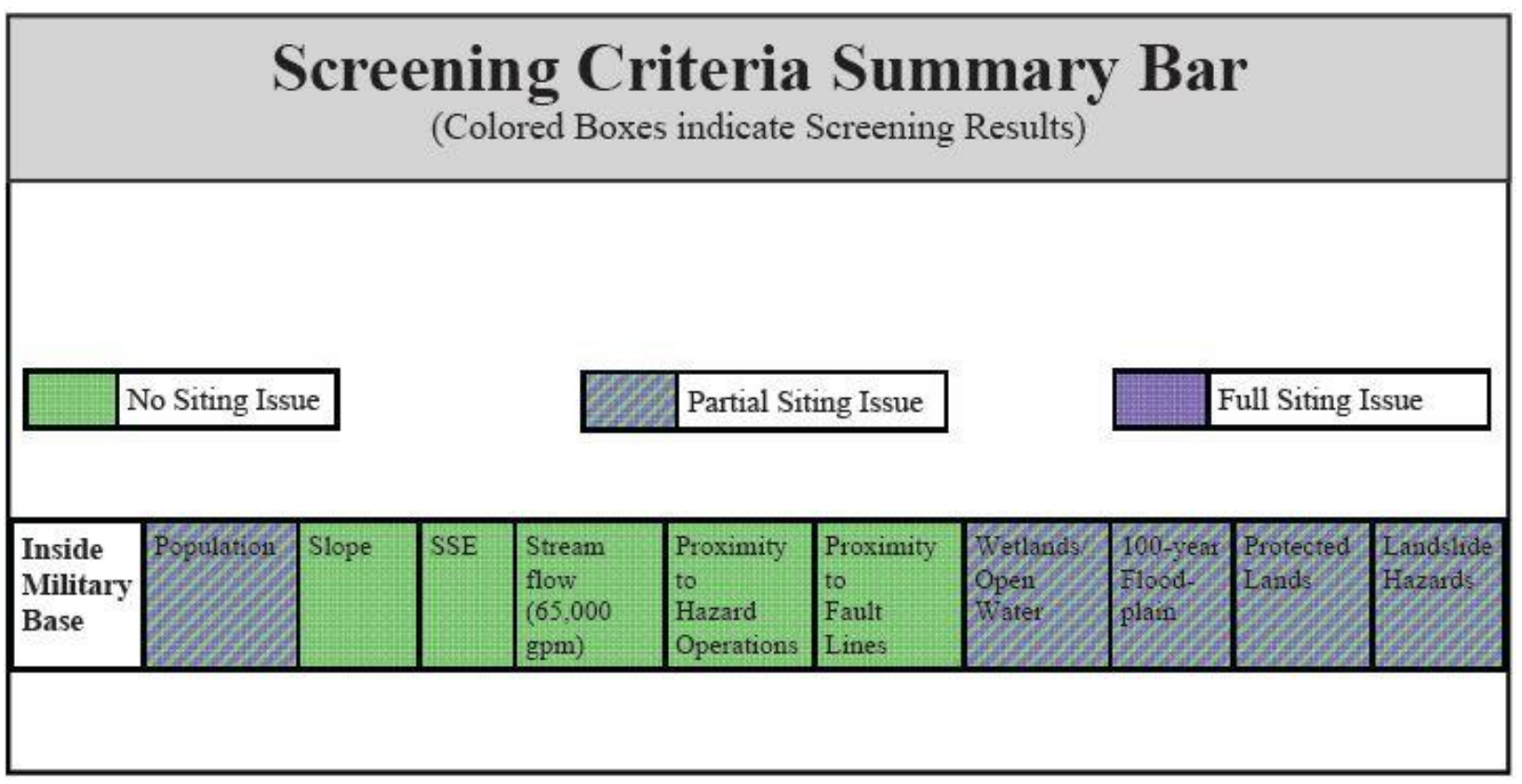

\begin{tabular}{|l|c|}
\hline \multicolumn{2}{|c|}{ Screening Criteria Table } \\
\hline \multicolumn{1}{|c|}{ Criteria } & Value \\
\hline Population Density within 10 miles (people/square mile) & $>500$ \\
\hline Slope & $>18 \%$ \\
\hline Safe shutdown earthquake (ground acceleration) & $>0.5$ \\
\hline Streamflow/cooling water make-up (gpm) & $<65,000$ \\
\hline Proximity to hazardous operations - buffer (mile) & Depends on hazardous operation ${ }^{1}$ \\
\hline Proximity to fault lines - buffer (mile) & Depends on length of fault \\
\hline Wetlands/Open Water & - \\
\hline 100-year floodplain & - \\
\hline Protected lands & - \\
\hline Landslide hazard (moderate and high) & - \\
\hline
\end{tabular}

${ }^{1}$ Hazardous facilities (airports- 5 miles and oil refineries-1 mile) 


\section{A.3.5 Composite Map and Individual Siting Issue Maps}

A composite map of SMR siting challenges to the Fort Benning is shown in Fig. A.9. Siting challenges are predominantly in the northwestern area of the post. Following this map are maps of the individual SMR siting criteria based on selected input values.

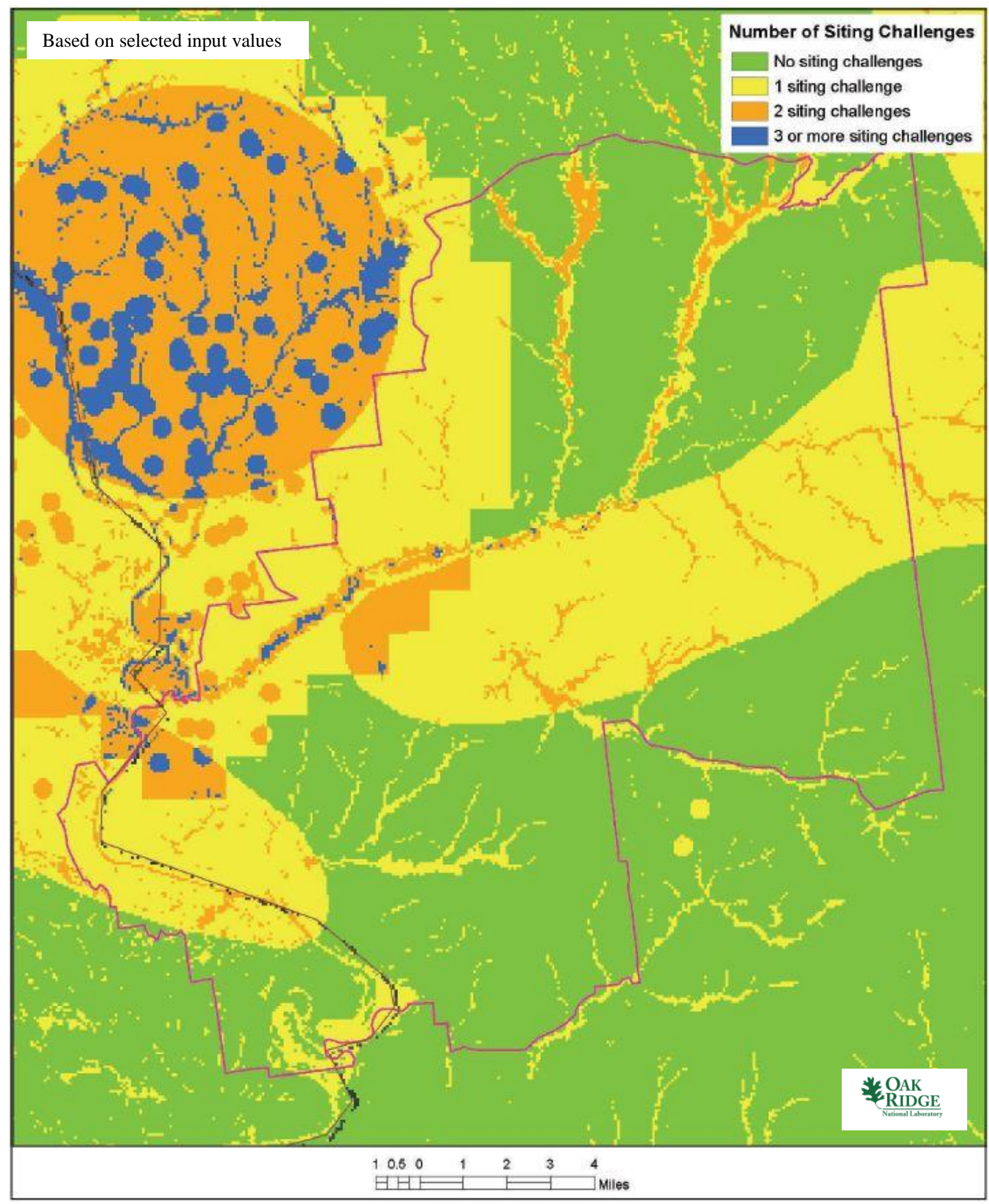

Fig. A.9. Fort Benning composite map. 

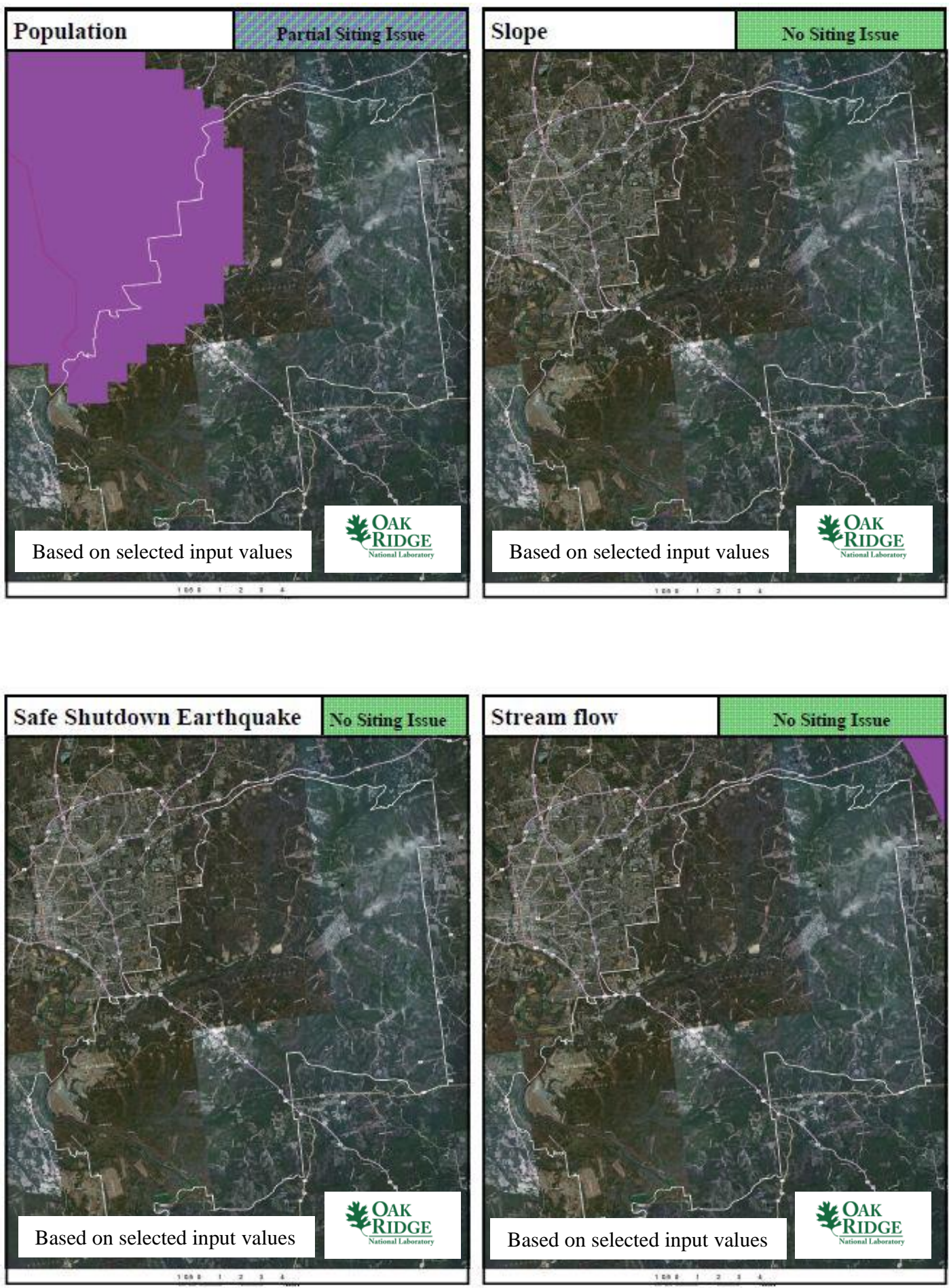

Fort Benning 

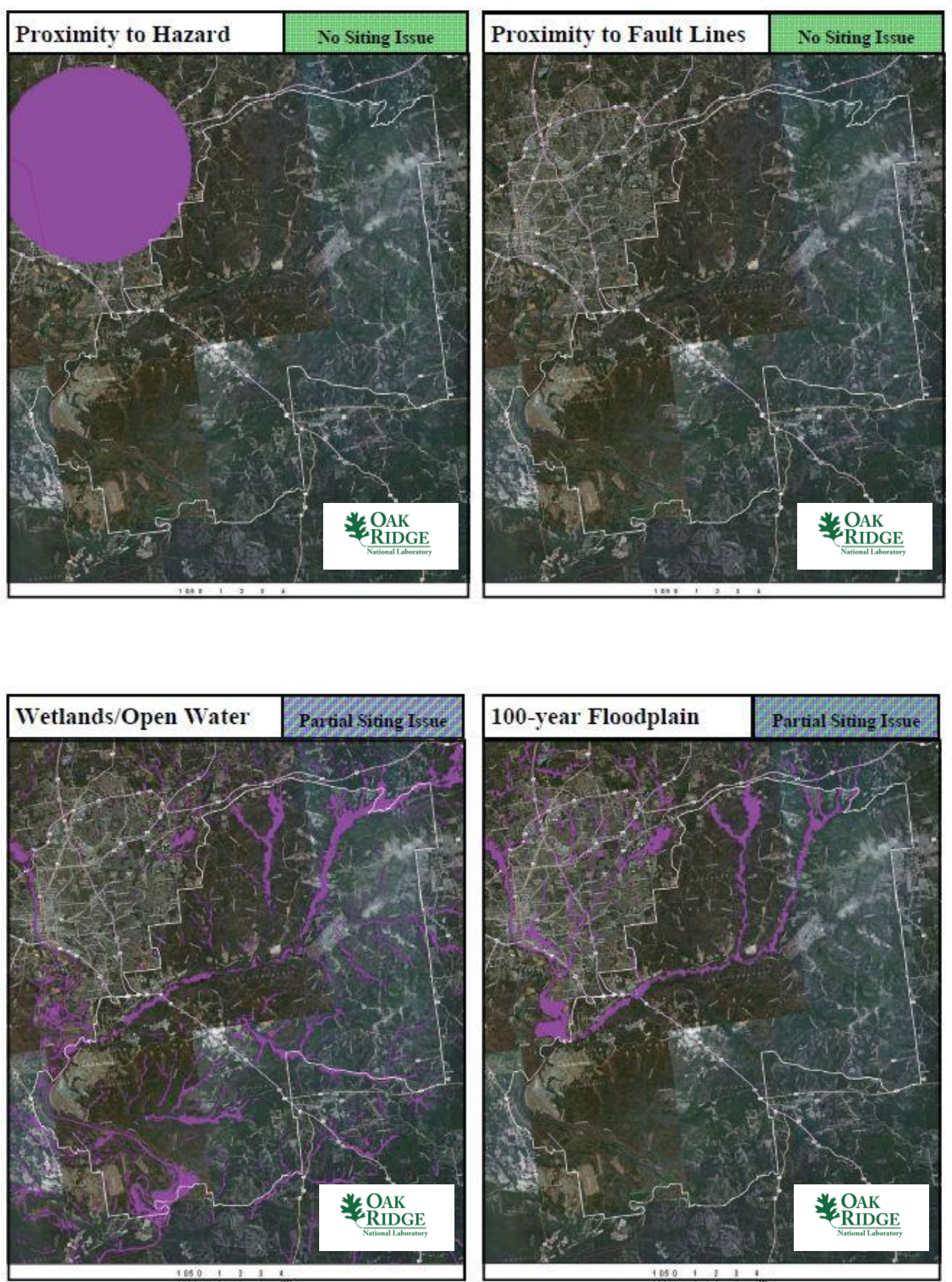

Fort Benning 

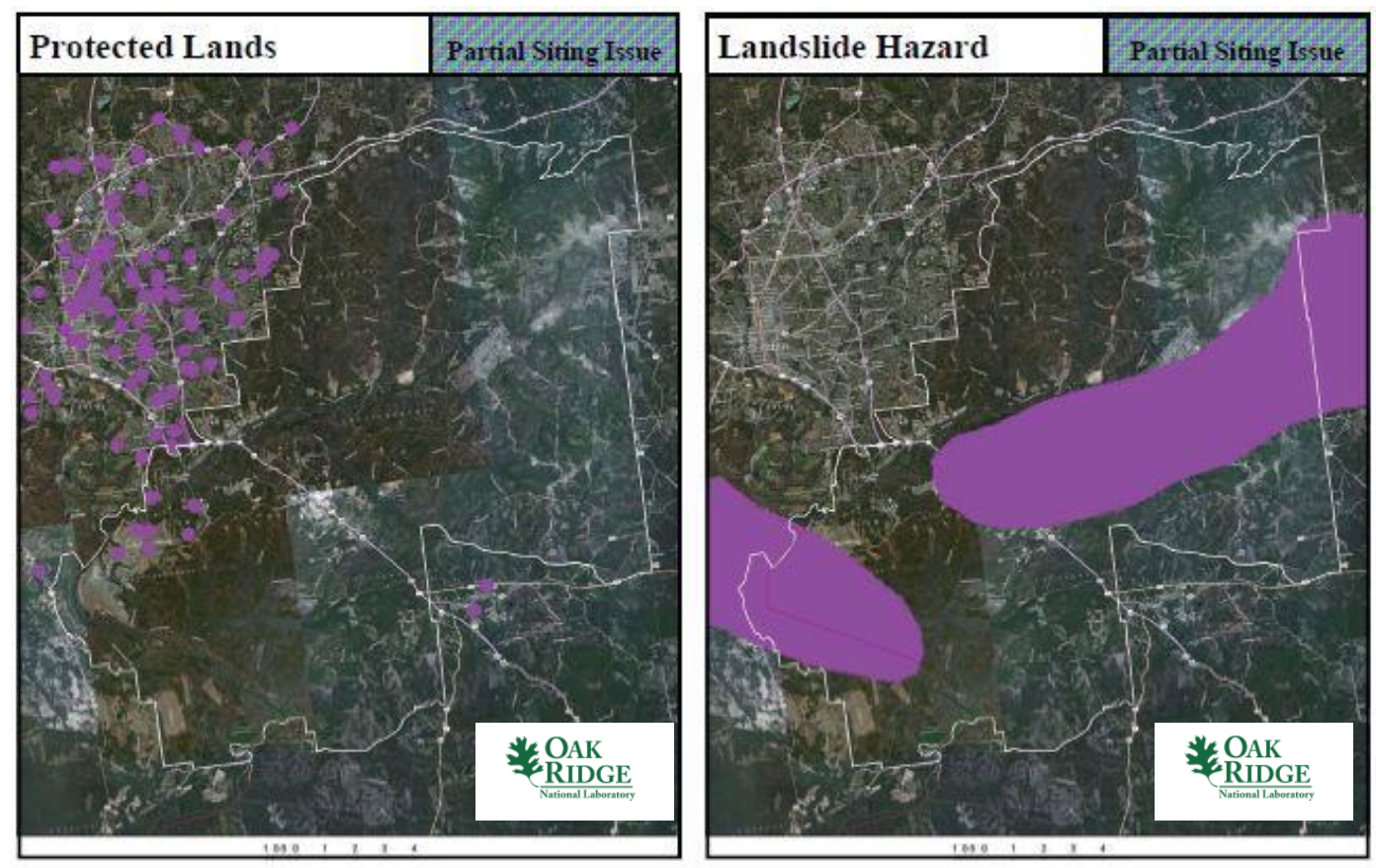

Fort Benning

\section{A.3.6 Site Evaluation}

Fort Benning is a large, federally controlled site. A well-trained, well-armed security force is available. Many of the activities and missions carried out on this base are high technology, mechanized endeavors. Personnel living or working on the base would have considerable familiarity with the technology- and security-related operations associated with nuclear power plant operation. Power demands on the base associated with the military missions and local infrastructure for current residents and workers would also be considerable and feasible for a site-located SMR.

As shown in Sects. A.3.4 and A.3.5, the Fort Benning site has partial site issues with population and landslide hazard. ${ }^{1}$ This essentially divides the site area into three distinct areas that meet all SMR SSEC. Approximately $50 \%$ of the 165,000-acre site meets multiple conventional standards for consideration of siting an SMR on the base facility. Note, however, that the composite map does not reflect specific hazards associated with the site, such as ordnance storage areas, weapons ranges, etc., that could render some areas of significant size as unsuitable for siting a reactor.

The site meets current NRC RG 4.7 recommendations for population density without additional consideration for relaxed SMR population siting requirements based on reduced source term. This site should be classified as favorable for siting an SMR. 


\section{A.4 FORT CAMPBELL}

\section{A.4.1 Location Detail}

As shown in Fig. A.10, Fort Campbell is located on about 93,000 acres ${ }^{6}$ (about 145 square miles) on the western border of Tennessee and Kentucky between the towns of Hopkinsville, Kentucky, and Clarksville, Tennessee, about 60 miles northwest of Nashville, Tennessee. Fort Campbell is home to the 101st Airborne Division, 5th Special Forces Group (Airborne), 160th Special Operations Aviation Regiment, 52nd Ordnance Group, US Army Medical Command, Installation Management Command, Network Enterprise Technology Command, US Air Force 19th Air Support Operation Squadron (ASOS) and Detachment 418 Weather Squadron, and other tenant groups, corps, units, institutes, or agencies. Interstate 24 is east of the base.

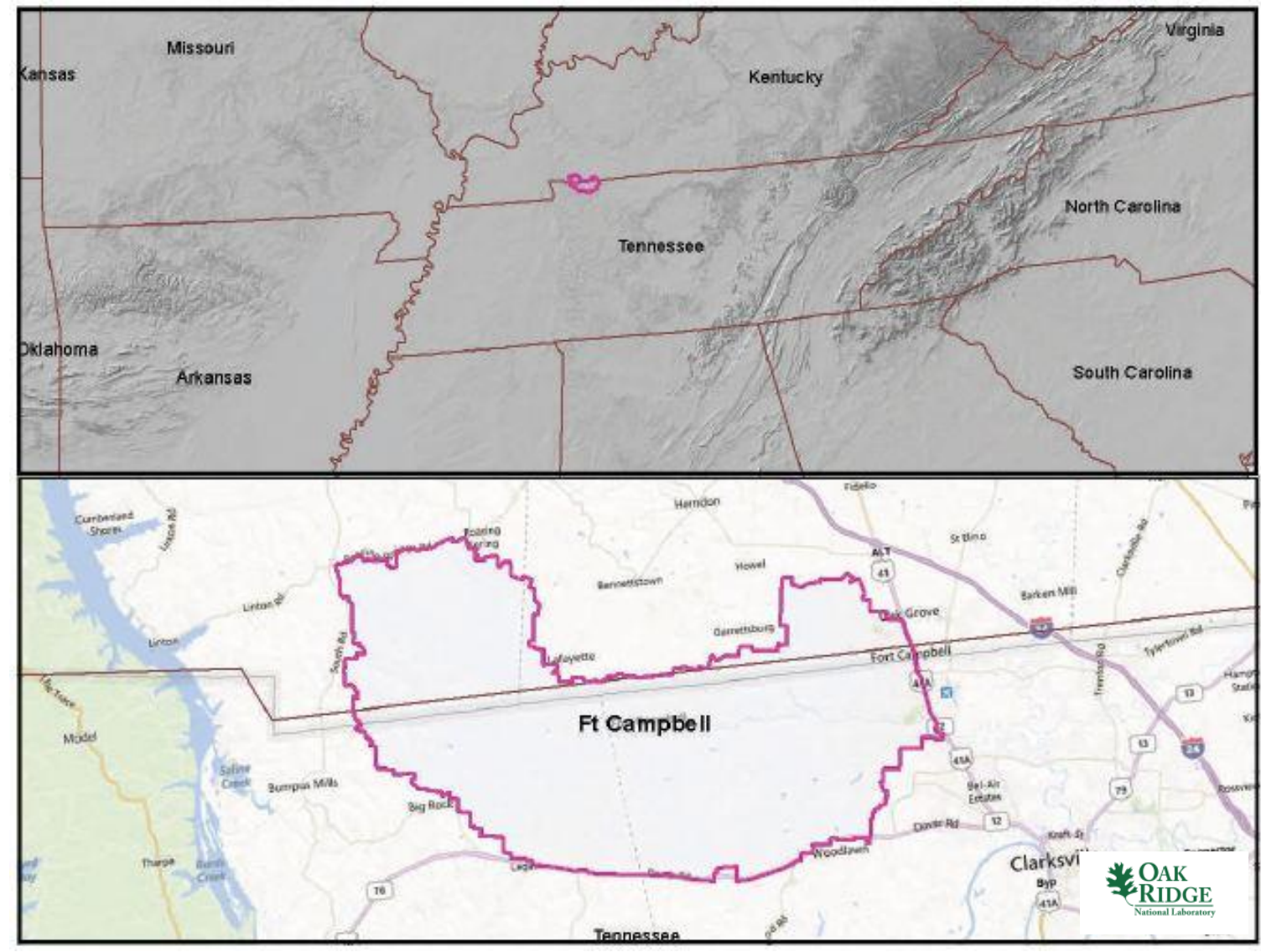

Fig. A.10. Fort Campbell.

\section{A.4.2 Site Description and Status}

The 101st Airborne Division, 5th Special Forces Group (Airborne), 160th Special Operations Aviation Regiment, 52nd Ordnance Group, and many other corps, units, institutes, or agencies are located at Fort Campbell. 
The population of Fort Campbell is about 30,000 active duty soldiers and over 50,000 family members. ${ }^{18}$ Descriptions of the installation, missions, and base history are readily available on the Internet. ${ }^{1,19,20}$

Services and resources are available on the base for military staff, families, employees, and services contractors similar to a small town, including lodging and housing, schools, hospital, various shopping facilities, restaurants, library, cultural and recreational amenities, and many other goods and services. ${ }^{1}$

As noted in Table A.7, the nearest major fault line based on USGS data is noted to be 570 miles west in Oklahoma. The maximum safe shutdown earthquake for the site is below $0.3 \mathrm{~g}$ peak ground acceleration. The maximum slope on the site is about $16 \%$. Greater than 100,000 gpm of cooling water makeup is

Table A.7. Fort Campbell site statistics

\begin{tabular}{|c|c|c|c|}
\hline \multicolumn{2}{|l|}{$\begin{array}{l}\text { Population } \\
\text { Population Within }\end{array}$} & \multicolumn{2}{|l|}{$\begin{array}{l}\text { Utility } \\
\text { Distance to Grid Capacity }\end{array}$} \\
\hline $0.5 \mathrm{mi}$ of Site Boundary & $\sim 94,000$ & $>400 \mathrm{MWe}$ & $\sim 15 \mathrm{mi}$ \\
\hline 1 mi of Site Boundary & $\sim 108,000$ & $>800 \mathrm{MWe}$ & $\sim 4.0 \mathrm{mi}$ \\
\hline $5 \mathrm{mi}$ of Site Boundary & $\sim 249,000$ & $>1600 \mathrm{MWe}$ & $\sim 10 \mathrm{mi}$ \\
\hline $10 \mathrm{mi}$ of Site Boundary & $\sim 444,000$ & $>3200 \mathrm{MWe}$ & $\sim 242 \mathrm{mi}$ \\
\hline \multicolumn{2}{|c|}{ Nearest City with Population } & \multicolumn{2}{|c|}{ Distance to Cooling Water } \\
\hline$>10,000$ & Hopkinsville, KY & $>50,000 \mathrm{gpm}$ & $\sim 7$ mi (Little River) \\
\hline$>50,000$ & Bowling Green, $\mathrm{KY}$ & $>100,000 \mathrm{gpm}$ & $\sim 7 \mathrm{mi}$ (Little River) \\
\hline$>100,000$ & Clarksville, TN & $>200,000 \mathrm{gpm}$ & $\begin{array}{c}\sim 4 \mathrm{mi} \text { (Cumberland } \\
\text { River) }\end{array}$ \\
\hline$>500,000$ & Nashville, TN & $>500,000 \mathrm{gpm}$ & $\begin{array}{c}\sim 4 \text { mi (Cumberland } \\
\text { River) }\end{array}$ \\
\hline \multicolumn{2}{|l|}{ Geotechnical } & \multicolumn{2}{|l|}{ Accessibility } \\
\hline Max Earthquake Acceleration & $\sim 0.3 \mathrm{~g}$ & Distance to Major Roadway & $\sim 1.0 \mathrm{mi}$ (Interstate 24$)$ \\
\hline Max Slope & $\sim 16 \%$ & Distance to Water Transport & $\sim 4.0 \mathrm{mi}$ (Pacific Deep) \\
\hline Nearest Fault Line & $\sim 570 \mathrm{mi}$ (Oklahoma) & Distance to Rail Transport & $\sim 0.1 \mathrm{mi}$ (USG) \\
\hline Nearest Hazard Site & $\begin{array}{l}50 \mathrm{mi} \text { (Airport- } \\
\text { Nashville Int' } 1)\end{array}$ & Distance to Airport & $\sim 50 \mathrm{mi}$ (Nashville Int' 1$)$ \\
\hline
\end{tabular}

available from the Little River. Greater than 500,000 gpm of cooling water makeup is available from the Cumberland River. Major highways, water transport, and rail transport are nearby.

\section{A.4.3 Aerial Imagery}

The aerial imagery in Fig. A.11 indicates the areas of population density in the east area of the base. Numerous base facilities, buildings, ranges, and training areas are located on this large site.

\section{A.4.4 Screening Criteria Overview}

Table A.8 shows a screening criteria summary bar, or "dashboard" chart, for the site area provides a quick look at what siting issues may exist for the site. The criteria that are not met within the site area indicated.

\footnotetext{
${ }^{18}$ http://apps.militaryonesource.mil/pls/psgprod/f?p=MI:CONTENT:1594691529077402::NO::P4_INST_ID:2695

${ }^{19} \mathrm{http}: / / \mathrm{www}$. Campbell.army.mil/

${ }^{20} \mathrm{http}: / /$ en.wikipedia.org/wiki/Fort_Campbell
} 


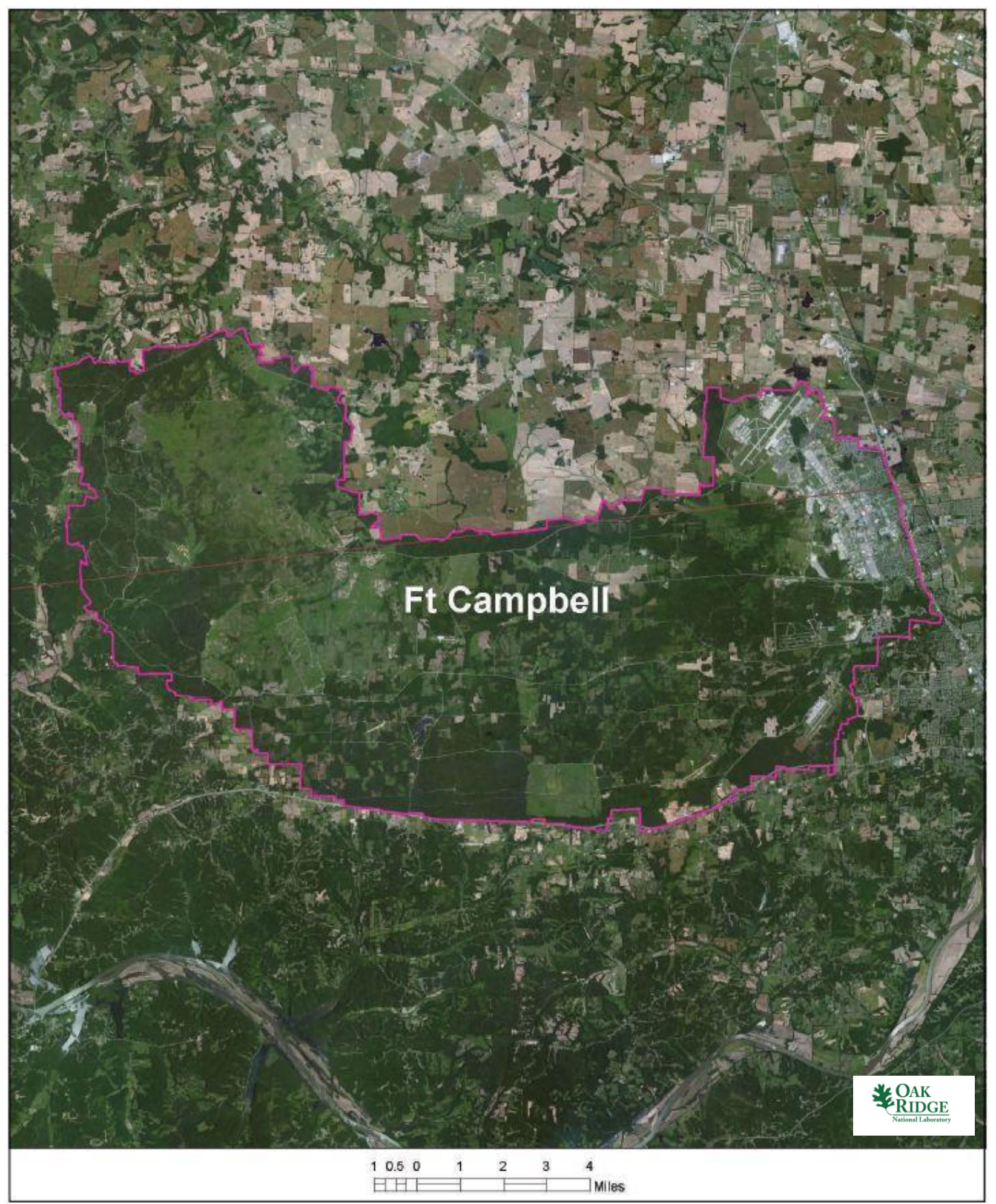

Fig. A.11. Satellite view of Fort Campbell area. 
Table A.8. Fort Campbell siting criteria summary

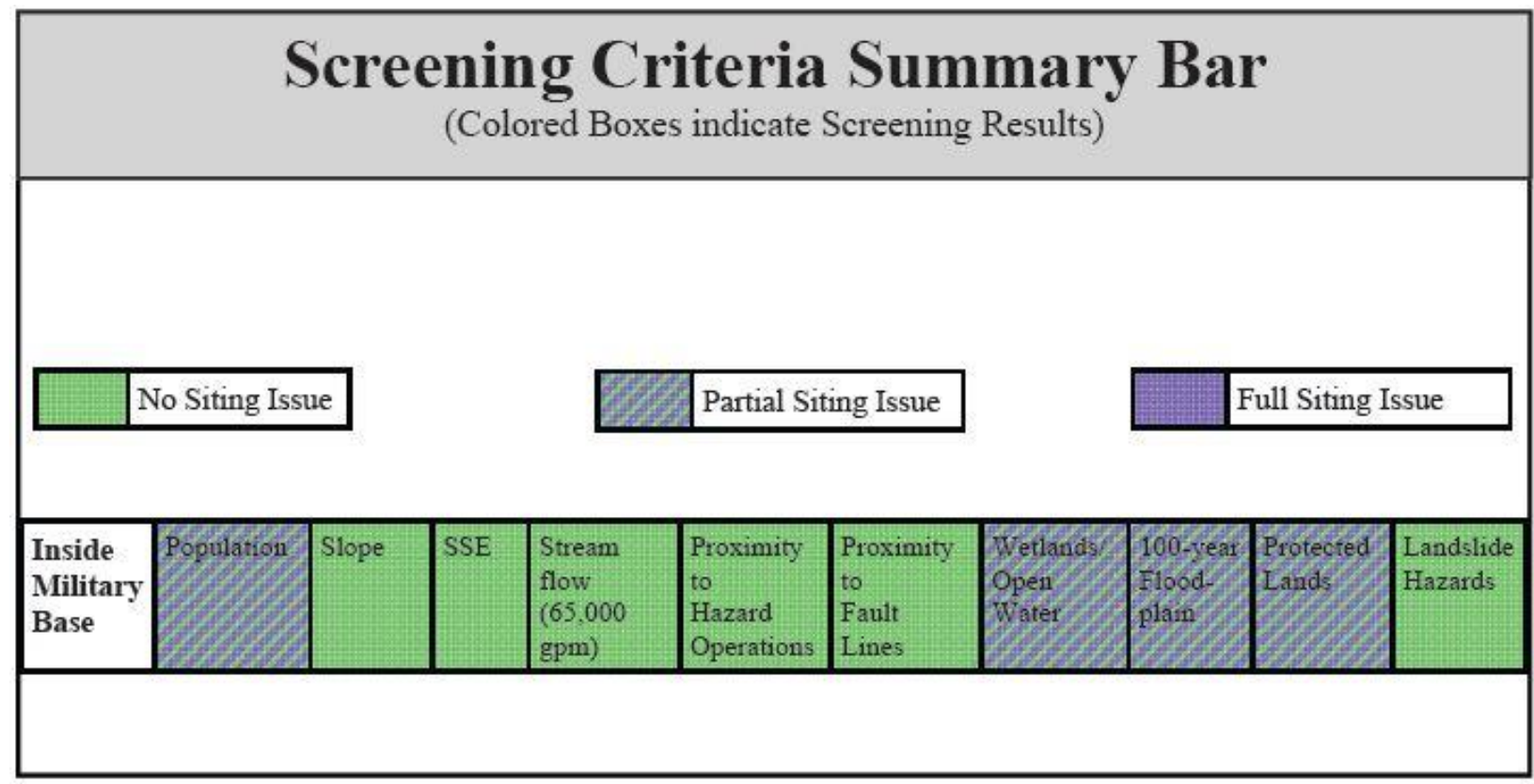

\begin{tabular}{|l|c|}
\hline \multicolumn{2}{|c|}{ Screening Criteria Table } \\
\hline \multicolumn{1}{|c|}{ Criteria } & Value \\
\hline Population Density within 10 miles (people/square mile) & $>500$ \\
\hline Slope & $>18 \%$ \\
\hline Safe shutdown earthquake (ground acceleration) & $>0.5$ \\
\hline Streamflow/cooling water make-up (gpm) & $<65,000$ \\
\hline Proximity to hazardous operations - buffer (mile) & Depends on hazardous operation ${ }^{1}$ \\
\hline Proximity to fault lines - buffer (mile) & Depends on length of fault \\
\hline Wetlands/Open Water & - \\
\hline 100 -year floodplain & - \\
\hline Protected lands & - \\
\hline Landslide hazard (moderate and high) & \\
\hline
\end{tabular}

${ }^{1}$ Hazardous facilities (airports-5 miles and oil refineries-1 mile) 


\section{A.4.5 Composite Map and Individual Siting Issue Maps}

A composite map of SMR siting challenges to the Fort Campbell is shown in Fig. A.12. Siting challenges are predominantly in the east area of the base. Following this map are maps of the individual SMR siting criteria based on selected input values.

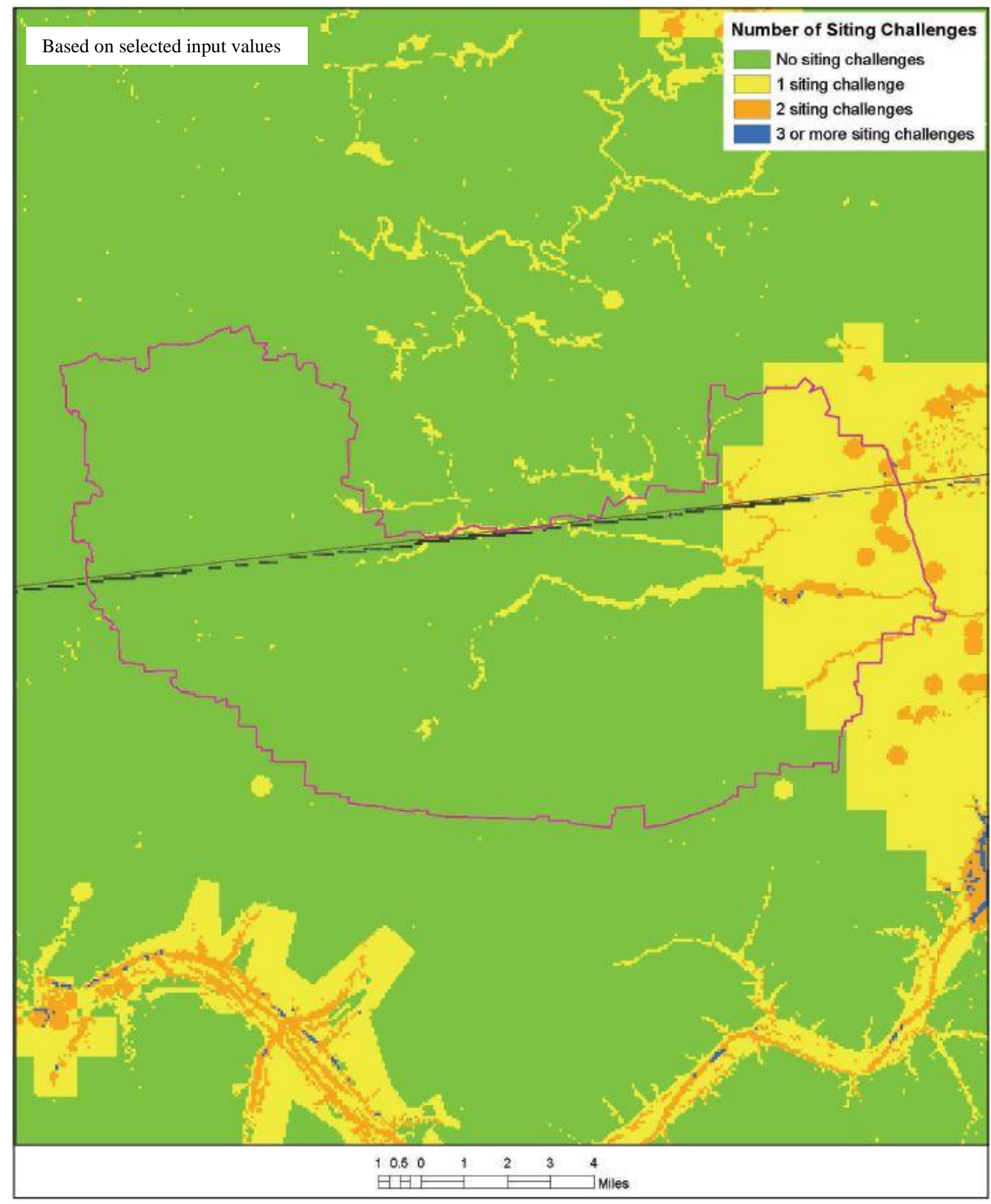

Fig. A.12. Fort Campbell composite map. 

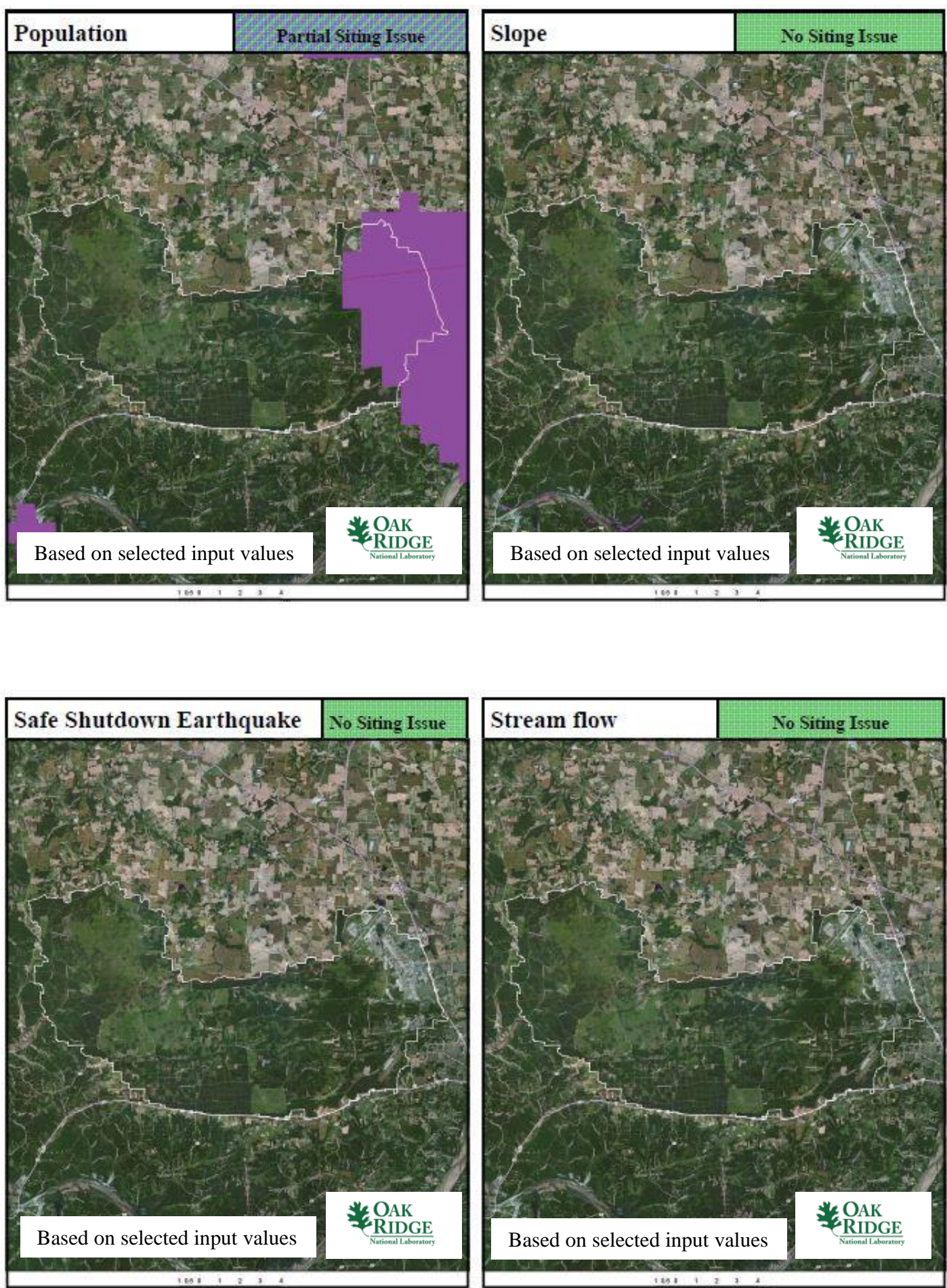

Fort Campbell 

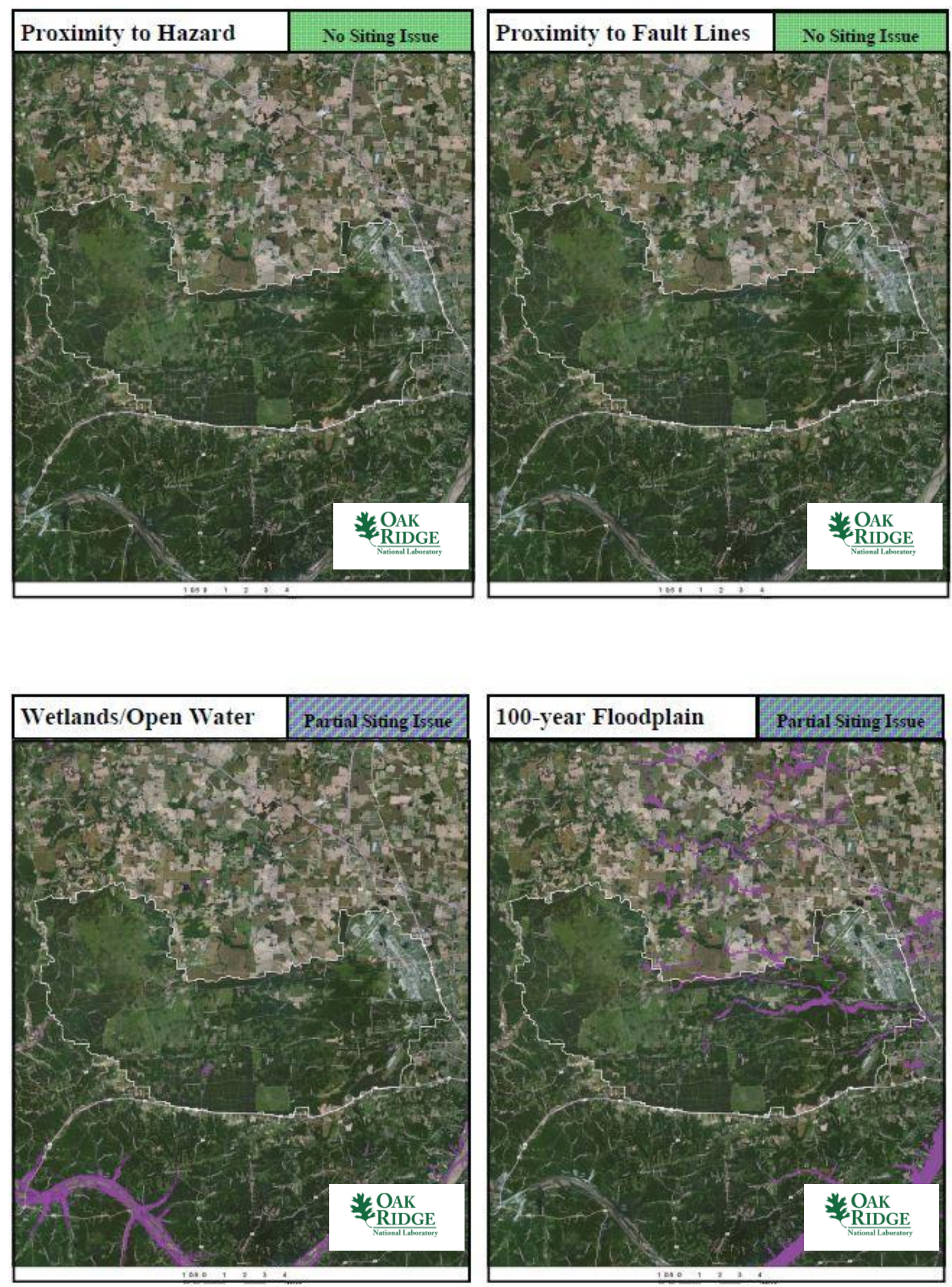

Fort Campbell 

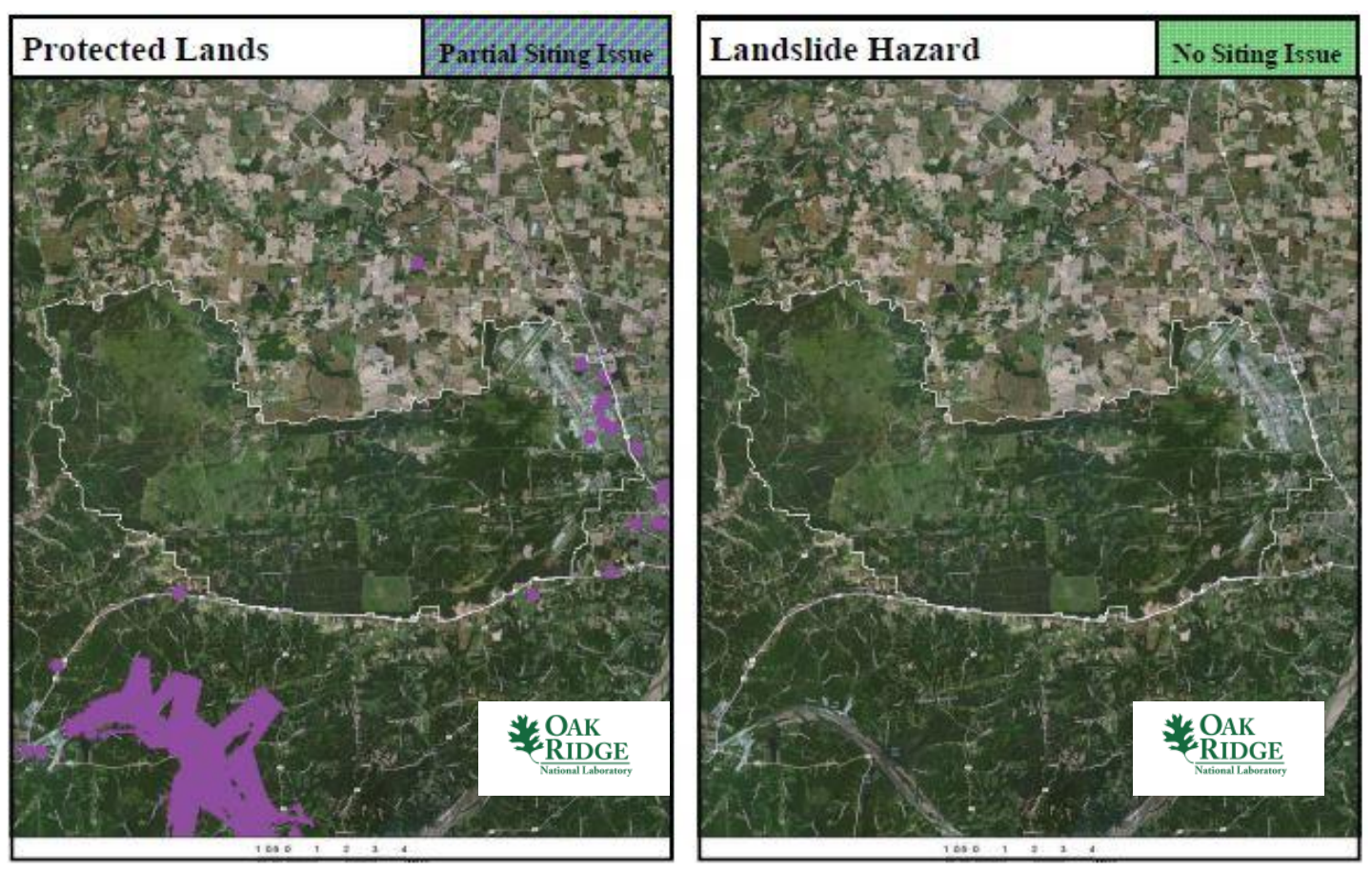

Fort Campbell

\section{A.4.6 Site Evaluation}

Fort Campbell is a large, federally controlled site. A well-trained, well-armed security force is available. Many of the activities and missions carried out on this base are high technology, mechanized endeavors. Personnel living or working on the base would have considerable familiarity with the technology- and security-related operations associated with nuclear power plant operation. Power demands on the base associated with the military missions and local infrastructure for current residents and workers would also be considerable and feasible for a site-located SMR.

As shown in Sects. A.4.4 and A.4.5, the Fort Campbell site has a partial site issues with population in the eastern portion of the site. ${ }^{1}$ Approximately $80 \%$ of the 93,000 -acre site meets multiple conventional standards for consideration of siting an SMR on the base facility. Note, however, that the composite map does not reflect specific hazards associated with the site, such as ordnance storage areas, weapons ranges, etc., that could render some areas of significant size as unsuitable for siting a reactor.

The site meets current NRC RG 4.7 recommendations for population density without additional consideration for relaxed SMR population siting requirements based on reduced source term. This site should be classified as favorable for siting an SMR. 


\section{A.5 FORT CARSON}

\section{A.5.1 Location Detail}

As shown in Fig. A.13, Fort Carson is located on about 122,000 acres ${ }^{6}$ (about 190 square miles) just south of Colorado Springs, Colorado. Fort Carson is home to the 4th Infantry Division, the 10th Special Forces Group, the 71st Ordnance Group (EOD), the 4th Engineer Battalion, the 759th Military Police Battalion, the 10th Combat Support Hospital, the 43rd Sustainment Brigade, and the 13th Air Support Operations Squadron of the United States Air Force and other elements. Interstate 25 is east of the base area.

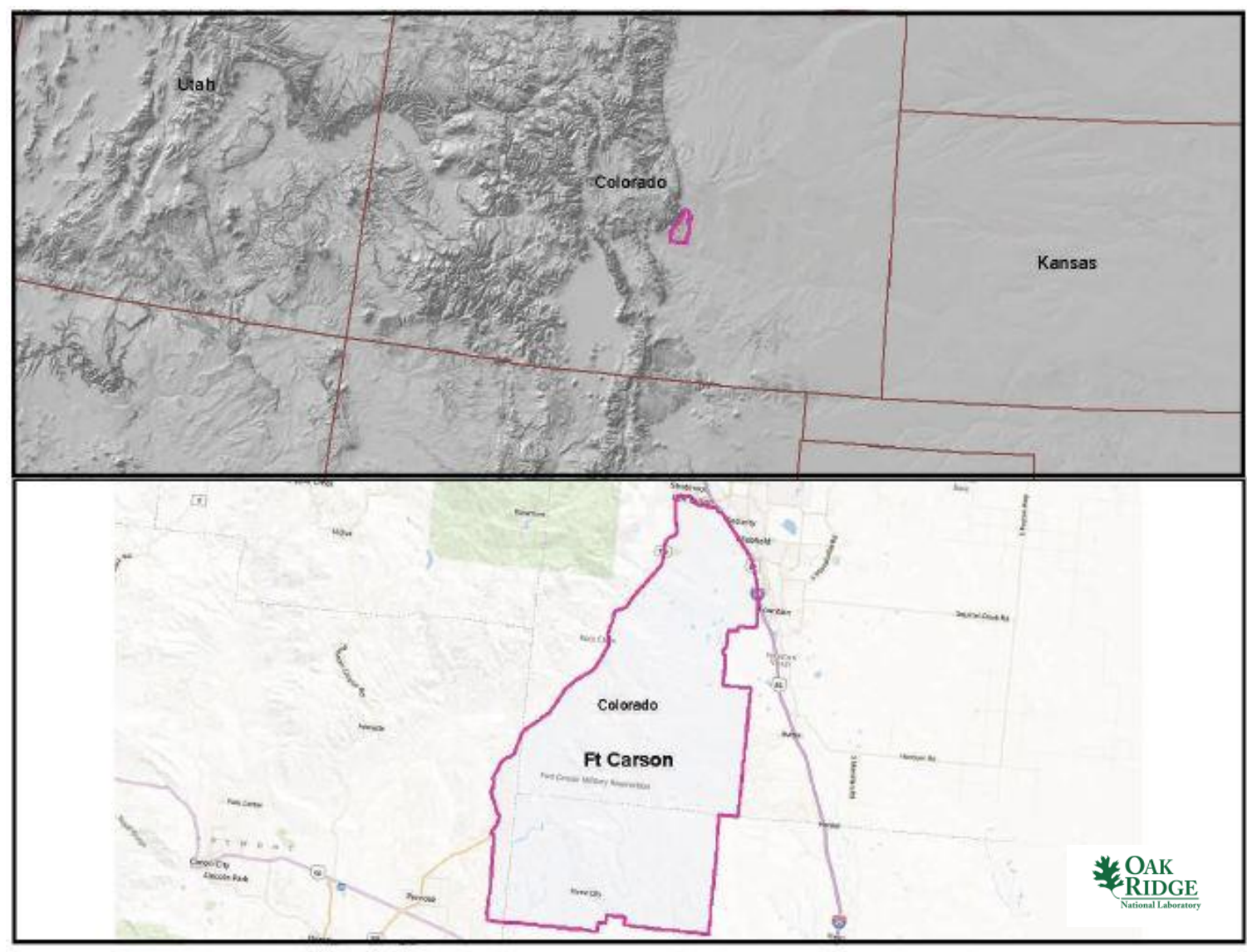

Fig. A.13. Fort Carson.

\section{A.5.2 Site Description and Status}

The 4th Infantry Division, the 10th Special Forces Group, the 71st Ordnance Group (EOD), the 4th Engineer Battalion, the 759th Military Police Battalion, the 10th Combat Support Hospital, the 43rd Sustainment Brigade, and the 13th Air Support Operations Squadron of the United States Air Force and other elements are located at Fort Carson.

Approximately, 70,000 soldiers, employees, families, and contractors form the population of the base area. ${ }^{21}$ Descriptions of the installation, missions, and base history are readily available on the Internet. $^{22,23,24}$

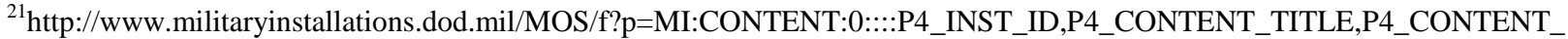
EKMT_ID,P4_CONTENT_DIRECTORY:835,Fast\%20Facts,30.90.30.30.60.0.0.0.0,1
} 
Services and resources are available on the base for military staff, families, employees, and services contractors similar to a small town, including lodging and housing, schools, hospital, various shopping facilities, restaurants, library, cultural and recreational amenities, and many other goods and services. ${ }^{25,26}$

As noted in Table A.9, the nearest major fault line based on USGS data is nearby at the northwest tip of the base. The maximum safe shutdown earthquake for the site is below $0.3 \mathrm{~g}$ peak ground acceleration. The maximum slope on the site is about $41 \%$. Greater than $500,000 \mathrm{gpm}$ of cooling water makeup is available from the Arkansas River to the southwest. Major highways and rail transport are nearby. Water transport is not available.

Table A.9. Fort Carson site statistics

\begin{tabular}{|c|c|c|c|}
\hline \multicolumn{2}{|l|}{$\begin{array}{l}\text { Population } \\
\text { Population Within }\end{array}$} & \multicolumn{2}{|l|}{$\begin{array}{l}\text { Utility } \\
\text { Distance to Grid Capacity }\end{array}$} \\
\hline $0.5 \mathrm{mi}$ of Site Boundary & $\sim 95,000$ & $>400 \mathrm{MWe}$ & $\sim 0.1 \mathrm{mi}$ \\
\hline 1 mi of Site Boundary & $\sim 137,000$ & $>800 \mathrm{MWe}$ & $\sim 80 \mathrm{mi}$ \\
\hline 5 mi of Site Boundary & $\sim 474,000$ & $>1600 \mathrm{MWe}$ & $\sim 346 \mathrm{mi}$ \\
\hline $10 \mathrm{mi}$ of Site Boundary & $\sim 1,020,000$ & $>3200 \mathrm{MWe}$ & $\sim 581 \mathrm{mi}$ \\
\hline \multicolumn{2}{|c|}{ Nearest City with Population } & \multicolumn{2}{|c|}{ Distance to Cooling Water } \\
\hline$>10,000$ & Fort Carson, $\mathrm{CO}$ & $>50,000 \mathrm{gpm}$ & $\sim 4$ mi (Arkansas River) \\
\hline$>50,000$ & Highlands Ranch, $\mathrm{CO}$ & $>100,000 \mathrm{gpm}$ & $\sim 4 \mathrm{mi}$ (Arkansas River) \\
\hline$>100,000$ & Colorado Spring, $\mathrm{CO}$ & $>200,000 \mathrm{gpm}$ & $\sim 4 \mathrm{mi}$ (Arkansas River) \\
\hline$>500,000$ & Denver, CO & $>500,000 \mathrm{gpm}$ & $\sim 4$ mi (Arkansas River) \\
\hline \multicolumn{2}{|l|}{ Geotechnical } & \multicolumn{2}{|l|}{ Accessibility } \\
\hline Max Earthquake Acceleration & $<0.3 \mathrm{~g}$ & Distance to Major Roadway & $\sim 0.1 \mathrm{mi}($ Interstate 25$)$ \\
\hline Max Slope & $\sim 41 \%$ & Distance to Water Transport & $\sim 444 \mathrm{mi}$ (Bering Sea) \\
\hline Nearest Fault Line & $\sim 0.1 \mathrm{mi}$ (Colorado) & Distance to Rail Transport & $\sim 0.1 \mathrm{mi}$ (USG) \\
\hline Nearest Hazard Site & $\begin{array}{l}\sim 5 \mathrm{mi} \text { (Airport- } \\
\text { City of Colorado Municipal) }\end{array}$ & Distance to Airport & $\begin{array}{c}\sim 5 \mathrm{mi} \text { (City of Colorado } \\
\text { Municipal) }\end{array}$ \\
\hline
\end{tabular}

\footnotetext{
${ }^{22} \mathrm{http} / / /$ www.Carson.army.mil/

${ }^{23} \mathrm{http}: / /$ en.wikipedia.org/wiki/Fort_Carson

${ }^{24} \mathrm{http} / / /$ www.militaryinstallations.dod.mil/mcfp-

web/mi_booklet.jsp?host=www.militaryinstallations.dod.mil\&inst_id=835\&booklet_items=

${ }^{25} \mathrm{http} / / / \mathrm{www} . \mathrm{mybaseguide.com/base/army/ft-carson}$

${ }^{26} \mathrm{http}: / /$ www.militaryinstallations.dod.mil/MOS/f?p=MI:CONTENT:0::::P4_INST_ID,P4_CONTENT_DIRECTORY,P4_

TAB:835,ALL,BK
} 


\section{A.5.3 Aerial Imagery}

The aerial imagery in Fig. A.14 indicates the areas of population density in the northern tip of the base. Numerous base facilities, buildings, ranges, and training areas are located on this site.

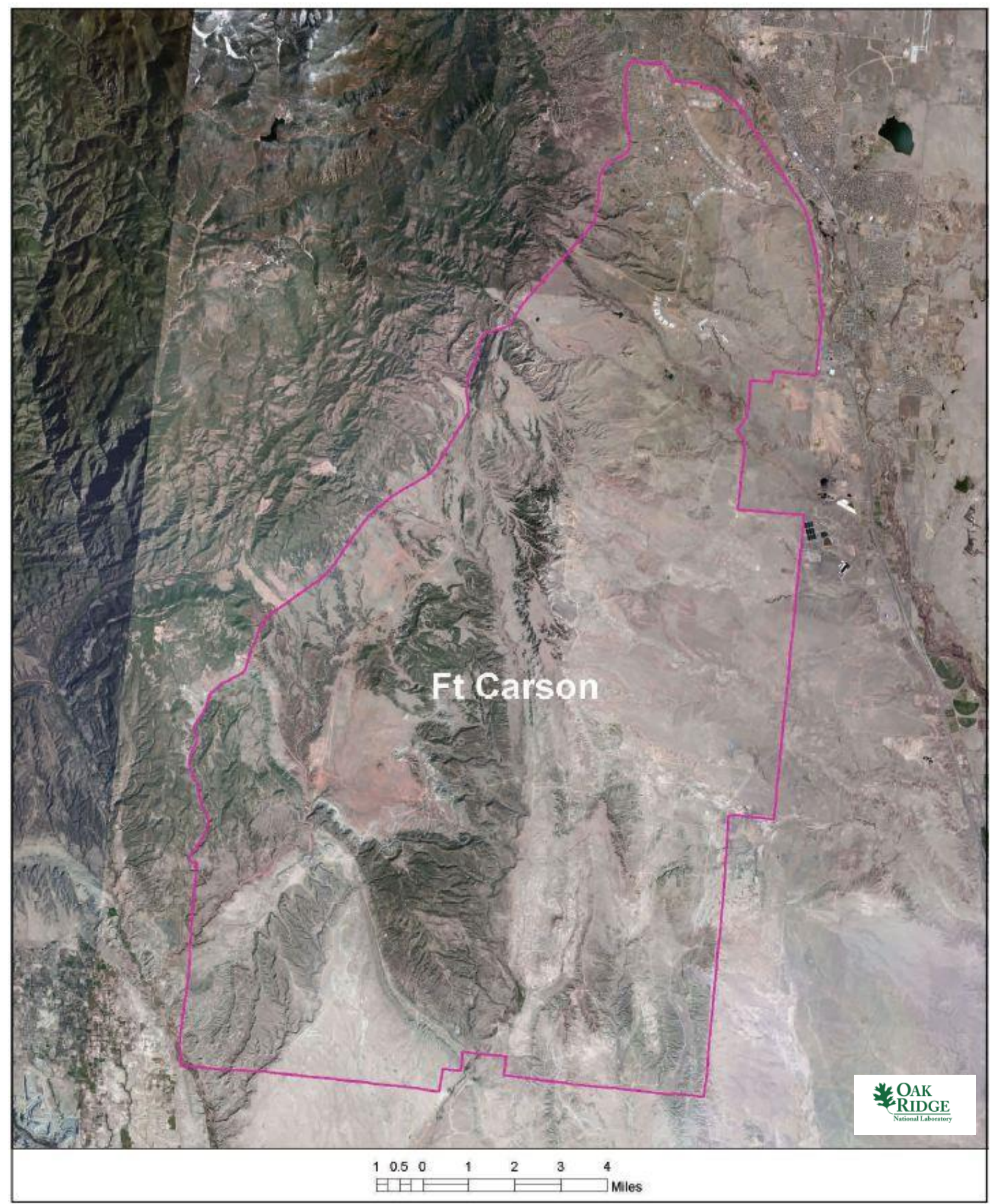

Fig. A.14. Satellite view of Fort Carson area. 


\section{A.5.4 Screening Criteria Overview}

Table A.10 shows a screening criteria summary bar, or "dashboard" chart, for the site area provides a quick look at what siting issues may exist for the site. The criteria that are not met within the site area indicated.

Table A.10. Fort Carson siting criteria summary

\section{Screening Criteria Summary Bar}

(Colored Boxes indicate Screening Results)

\begin{tabular}{|c|c|c|c|c|c|c|c|c|c|}
\hline \multicolumn{2}{|r|}{ No Siting Issue } & \multicolumn{4}{|c|}{ Partial Siting Issue } & & \multicolumn{3}{|c|}{ Full Siting Issue } \\
\hline $\begin{array}{l}\text { Inside } \\
\text { Military } \\
\text { Base }\end{array}$ & & SSE & $\begin{array}{l}\text { Strean } \\
\text { flow } \\
(65.000 \\
\text { gpmi) }\end{array}$ & $\begin{array}{l}\text { Proximity } \\
\text { to } \\
\text { Hazard } \\
\text { Operations }\end{array}$ & $\begin{array}{l}\text { Proxinity } \\
\text { to } \\
\text { Fanle } \\
\text { Lines }\end{array}$ & $\begin{array}{l}\text { Wetlands/ } \\
\text { Open } \\
\text { Water }\end{array}$ & $\begin{array}{l}\text { 100-year } \\
\text { Flood- } \\
\text { plain }\end{array}$ & $\begin{array}{l}\text { Protected } \\
\text { Lands }\end{array}$ & $\begin{array}{l}\text { Landside } \\
\text { Hazard }\end{array}$ \\
\hline
\end{tabular}

\begin{tabular}{|l|c|}
\hline \multicolumn{2}{|c|}{ Screening Criteria Table } \\
\hline \multicolumn{1}{|c|}{ Criteria } & Value \\
\hline Population Density within 10 miles (people/square mile) & $>500$ \\
\hline Slope & $>18 \%$ \\
\hline Safe shutdown earthquake (ground acceleration) & $>0.5$ \\
\hline Streamflow/cooling water make-up (gpm) & $<65,000$ \\
\hline Proximity to hazardous operations - buffer (mile) & Depends on hazardous operation ${ }^{1}$ \\
\hline Proximity to fault lines - buffer (mile) & Depends on length of fault \\
\hline Wetlands/Open Water & - \\
\hline 100-year floodplain & - \\
\hline Protected lands & - \\
\hline Landslide hazard (moderate and high) & - \\
\hline
\end{tabular}

${ }^{1}$ Hazardous facilities (airports- 5 miles and oil refineries -1 mile) 


\section{A.5.5 Composite Map and Individual Siting Issue Maps}

A composite map of SMR siting challenges to the Fort Carson is shown in Fig. A.15. Siting challenges (populated areas and stream flow) are predominantly in the northern area of the base. Following this map are maps of the individual SMR siting criteria based on selected input values.

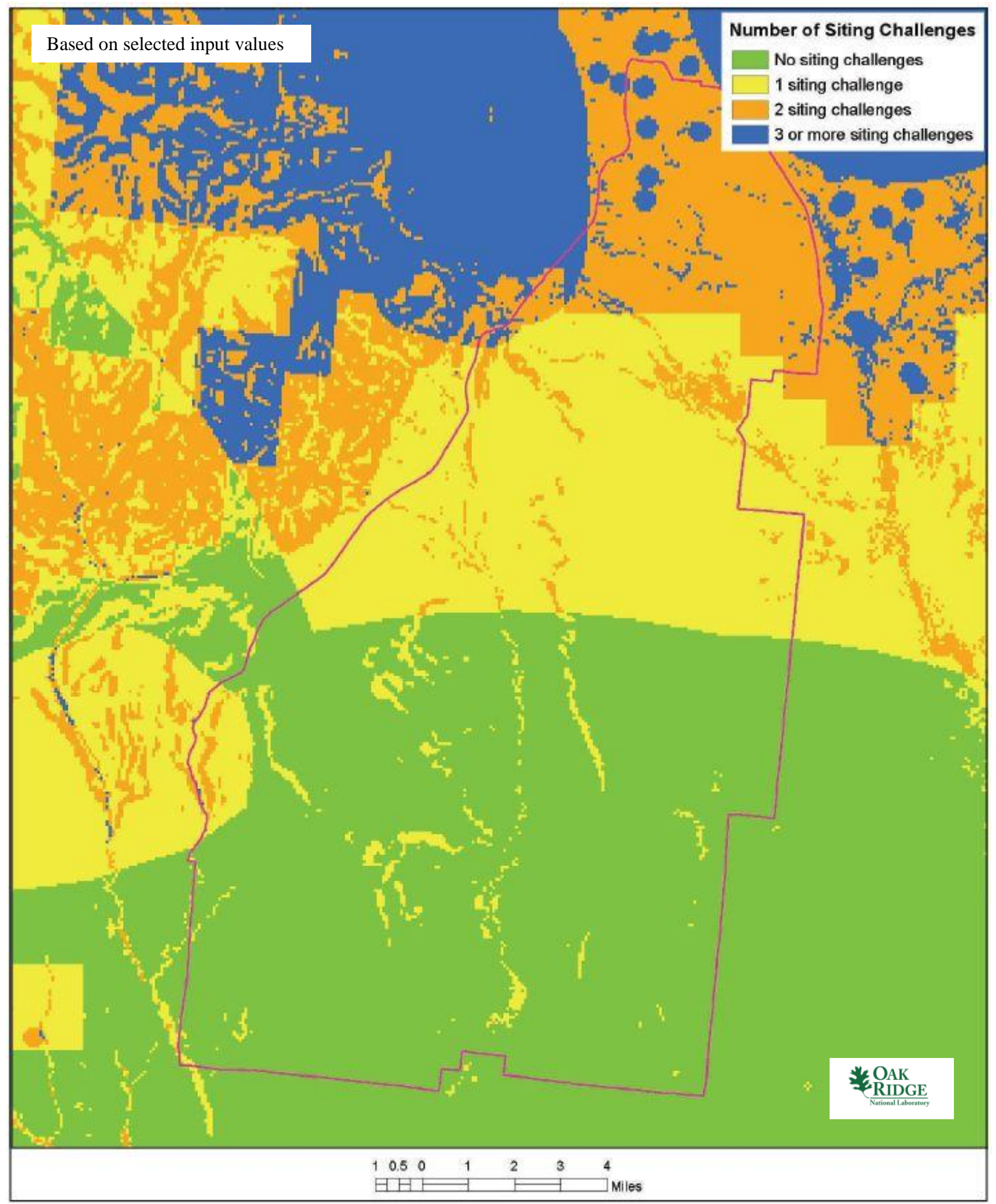

Fig. A.15. Fort Carson composite map. 

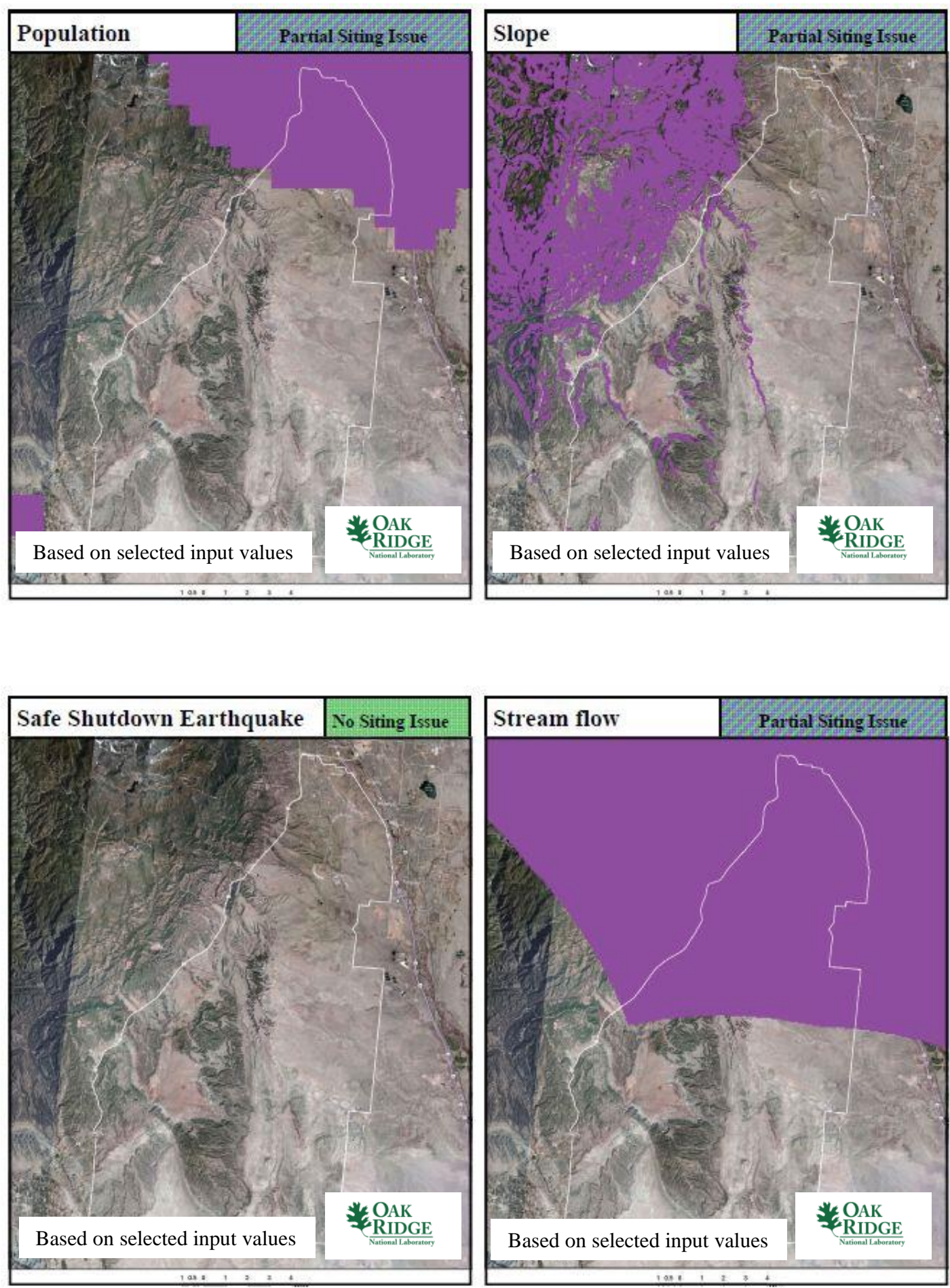

Fort Carson 

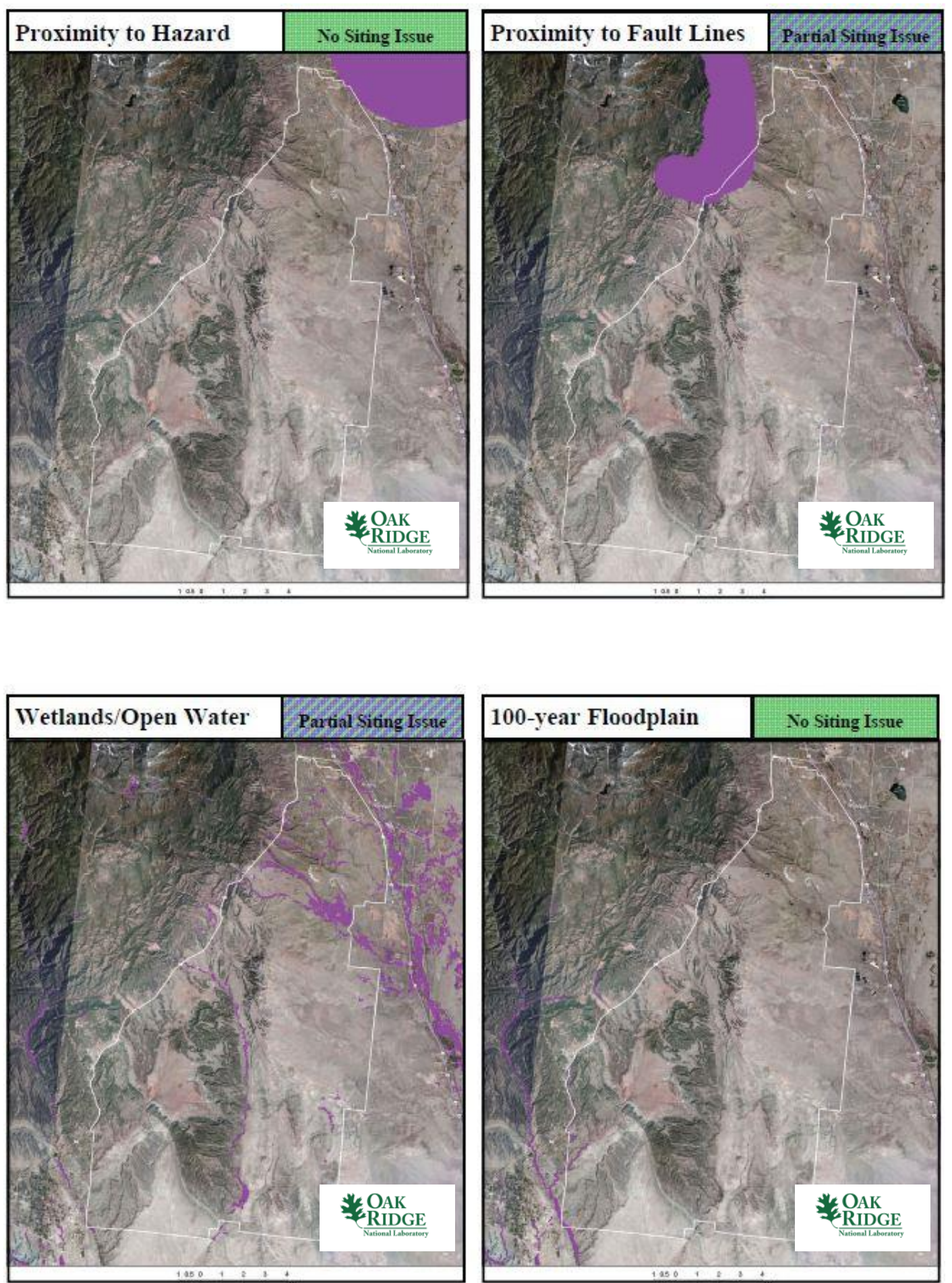

Fort Carson 

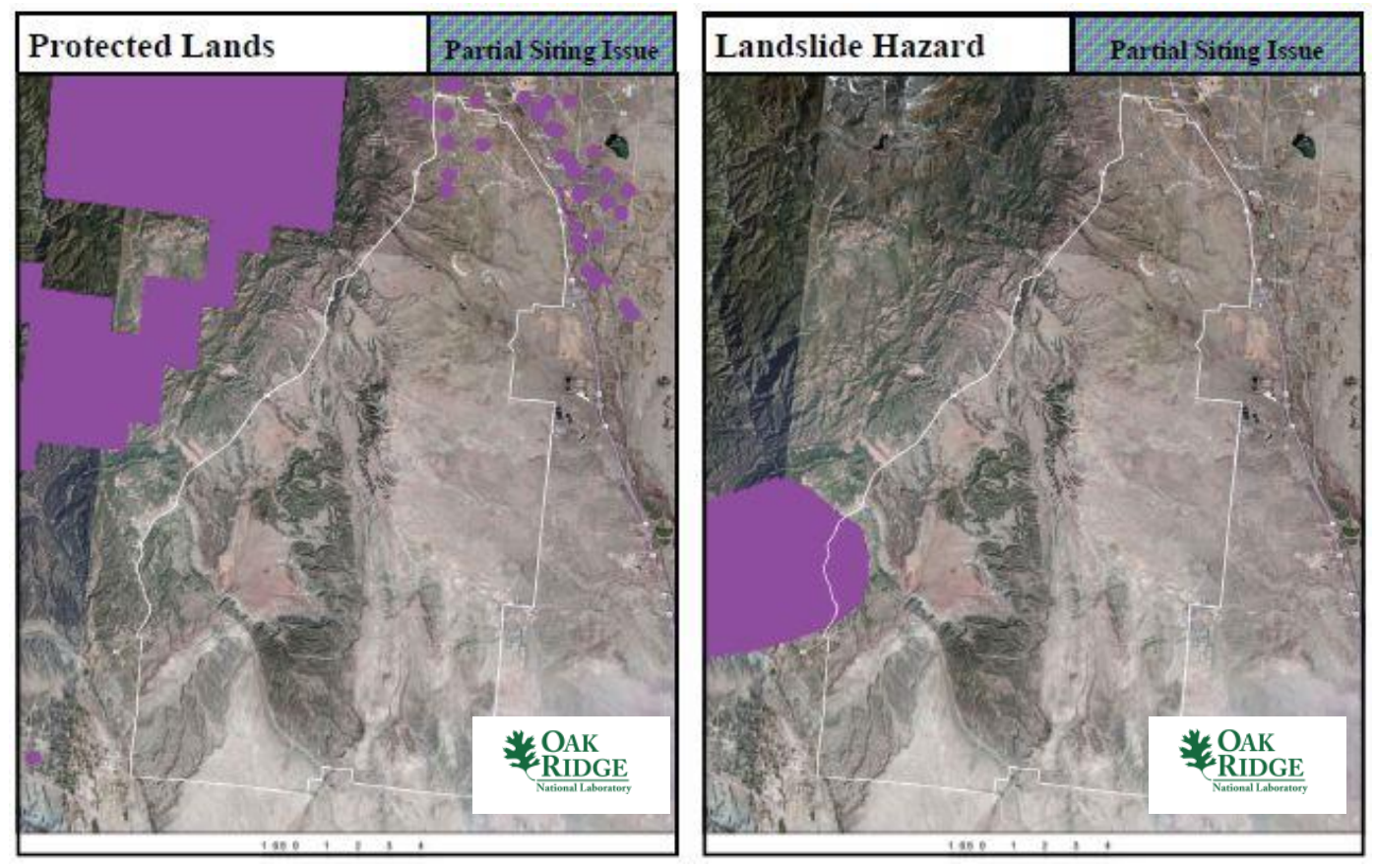

Fort Carson

\section{A.5.6 Site Evaluation}

Fort Carson is a large, federally controlled site. A well-trained, well-armed security force is available. Many of the activities and missions carried out on this base are high technology, mechanized endeavors. Personnel living or working on the base would have considerable familiarity with the technology- and security-related operations associated with nuclear power plant operation. Power demands on the base associated with the military missions and local infrastructure for current residents and workers would also be considerable and feasible for a site-located SMR.

As shown in Sects. A.5.4 and A.5.5, the Fort Carson site has multiple partial site issues. ${ }^{1}$ This primarily impacts areas in the northern section of the site. Approximately $60 \%$ of the 122,000 -acre site meets multiple conventional standards for consideration of siting an SMR on the base facility. Note, however, that the composite map does not reflect specific hazards associated with the site, such as ordnance storage areas, weapons ranges, etc., that could render some areas of significant size as unsuitable for siting a reactor.

The site meets current NRC RG 4.7 recommendations for population density without additional consideration for relaxed SMR population siting requirements based on reduced source term. This site should be classified as favorable for siting an SMR. 


\section{A.6 FORT DRUM}

\section{A.6.1 Location Detail}

As shown in Fig. A.16, Fort Drum is located on about 97,000 acres ${ }^{6}$ (about 150 square miles) approximately 30 miles from Canada, with the Great Lakes to the west, the Adirondack Mountains to the east, and the St. Lawrence River and the Thousand Islands in between. Fort Drum is home to the 10th Mountain Division, supporting organizations, units, groups and several tenant units. Interstate 81 is west of the base.

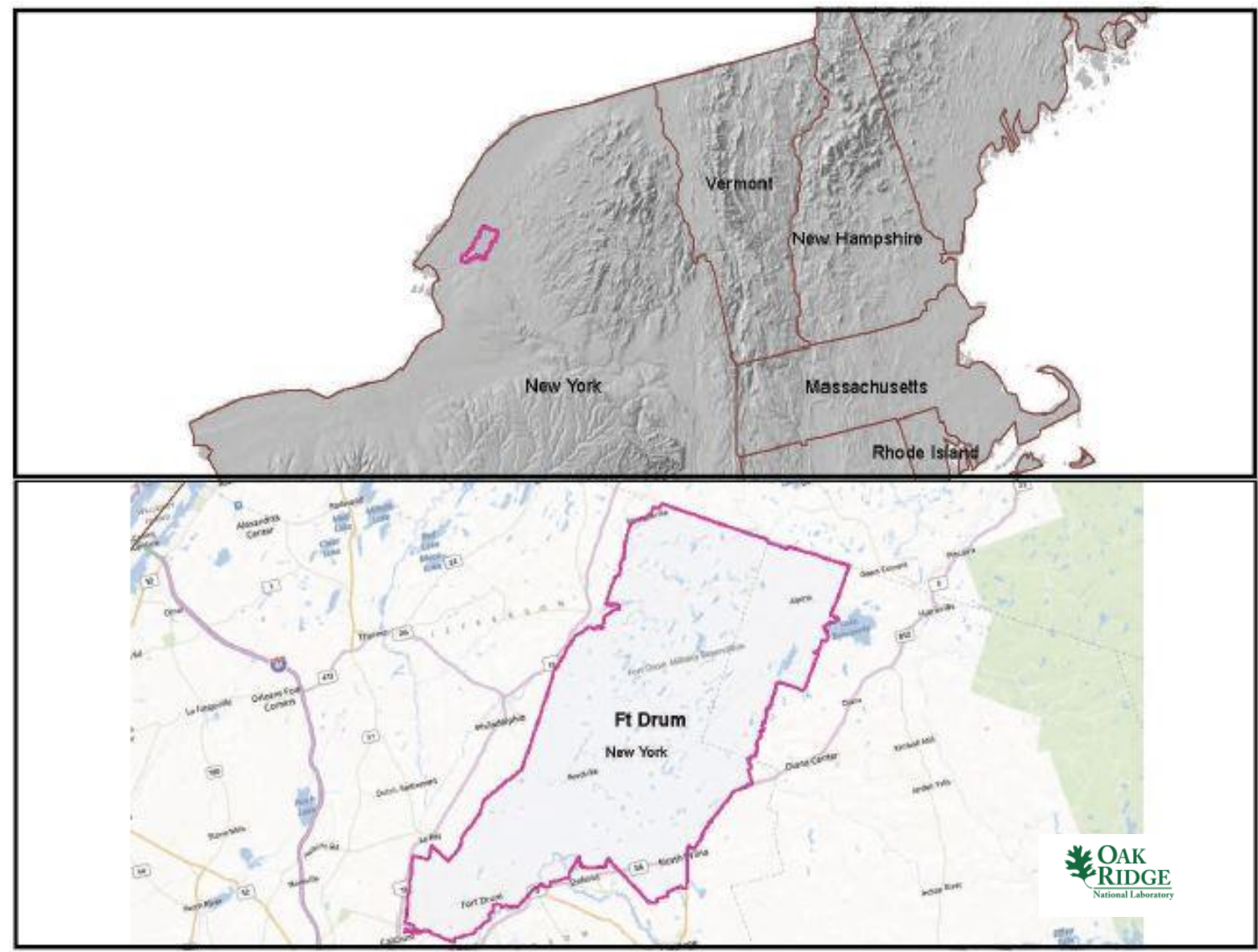

Fig. A.16. Fort Drum.

\section{A.6.2 Site Description and Status}

The 10th Mountain Division, supporting organizations, units, groups and several tenant units are located at Fort Drum.

The population of Fort Drum is about 20,000 active duty soldiers and over 20,000 family members. ${ }^{27}$ Descriptions of the installation, missions, and base history are readily available on the Internet. ${ }^{1,28,29}$

Services and resources are available on the base for military staff, families, employees, and services contractors similar to a small town, including lodging and housing, schools, hospital, various shopping facilities, restaurants, library, cultural and recreational amenities, and many other goods and services. ${ }^{1}$

\footnotetext{
${ }^{27} \mathrm{http}: / /$ www.drum.army.mil/AboutFortDrum/Pages/AboutFortDrum_lv1.aspx

${ }^{28} \mathrm{http}: / / \mathrm{www} \cdot$ drum.army.mil/

${ }^{29} \mathrm{http}: / /$ en.wikipedia.org/wiki/Fort_Drum
} 
As noted in Table A.11, the nearest major fault line based on USGS data is noted to be 1,267 miles southwest in Kansas. The maximum safe shutdown earthquake for the site is below $0.3 \mathrm{~g}$ peak ground acceleration. The maximum slope on the site is about $23 \%$. Greater than 100,000 gpm of cooling water makeup is available from the Indian River. Greater than 500,000 gpm of cooling water makeup is available from the Black River. Major highways and rail transport are nearby. Water transport is about 15 miles away.

Table A.11. Fort Drum site statistics

\begin{tabular}{|c|c|c|c|}
\hline \multicolumn{2}{|l|}{$\begin{array}{l}\text { Population } \\
\text { Population Within }\end{array}$} & \multicolumn{2}{|l|}{$\begin{array}{l}\text { Utility } \\
\text { Distance to Grid Capacity }\end{array}$} \\
\hline $0.5 \mathrm{mi}$ of Site Boundary & $\sim 49,000$ & $>400 \mathrm{MWe}$ & $\sim 38 \mathrm{mi}$ \\
\hline $1 \mathrm{mi}$ of Site Boundary & $\sim 56,000$ & $>800 \mathrm{MWe}$ & $\sim 41 \mathrm{mi}$ \\
\hline $5 \mathrm{mi}$ of Site Boundary & $\sim 142,500$ & $>1600 \mathrm{MWe}$ & $\sim 18 \mathrm{mi}$ \\
\hline $10 \mathrm{mi}$ of Site Boundary & $\sim 250,000$ & $>3200 \mathrm{MWe}$ & $\sim 49 \mathrm{mi}$ \\
\hline \multicolumn{2}{|c|}{ Nearest City with Population } & \multicolumn{2}{|c|}{ Distance to Cooling Water } \\
\hline$>10,000$ & Watertown, NY & $>50,000 \mathrm{gpm}$ & $\sim 0.1 \mathrm{mi}$ (Indian River) \\
\hline$>50,000$ & Utica, NY & $>100,000 \mathrm{gpm}$ & $\sim 0.1$ mi (Indian River) \\
\hline$>100,000$ & Syracuse, NY & $>200,000 \mathrm{gpm}$ & $\sim 0.1 \mathrm{mi}$ (Black River) \\
\hline$>500,000$ & New York City, NY & $>500,000 \mathrm{gpm}$ & $\sim 0.1 \mathrm{mi}$ (Black River) \\
\hline \multicolumn{2}{|l|}{ Geotechnical } & \multicolumn{2}{|l|}{ Accessibility } \\
\hline Max Earthquake Acceleration & $<0.3 \mathrm{~g}$ & Distance to Major Roadway & $\sim 3 \mathrm{mi}($ Interstate 81$)$ \\
\hline Max Slope & $\sim 23 \%$ & Distance to Water Transport & $\begin{array}{c}\sim 15 \text { mi (Vermilion Bay } \\
\text { Offshore) }\end{array}$ \\
\hline Nearest Fault Line & $\sim 1,267 \mathrm{mi}$ (Kansas) & Distance to Rail Transport & $\sim 0.1 \mathrm{mi}(\operatorname{CSXT})$ \\
\hline Nearest Hazard Site & $\begin{array}{l}\sim 60 \text { mi (Airport- } \\
\quad \text { Syracuse Hancook Int '1) }\end{array}$ & Distance to Airport & $\begin{array}{c}\sim 60 \mathrm{mi} \text { (Syracuse Hancook } \\
\text { Int' '1) }\end{array}$ \\
\hline
\end{tabular}

\section{A.6.3 Aerial Imagery}

The aerial imagery in Fig. A.17 indicates the areas of population density in the east area of the base. Numerous base facilities, buildings, ranges, airfield, and training areas are located on this large site. 


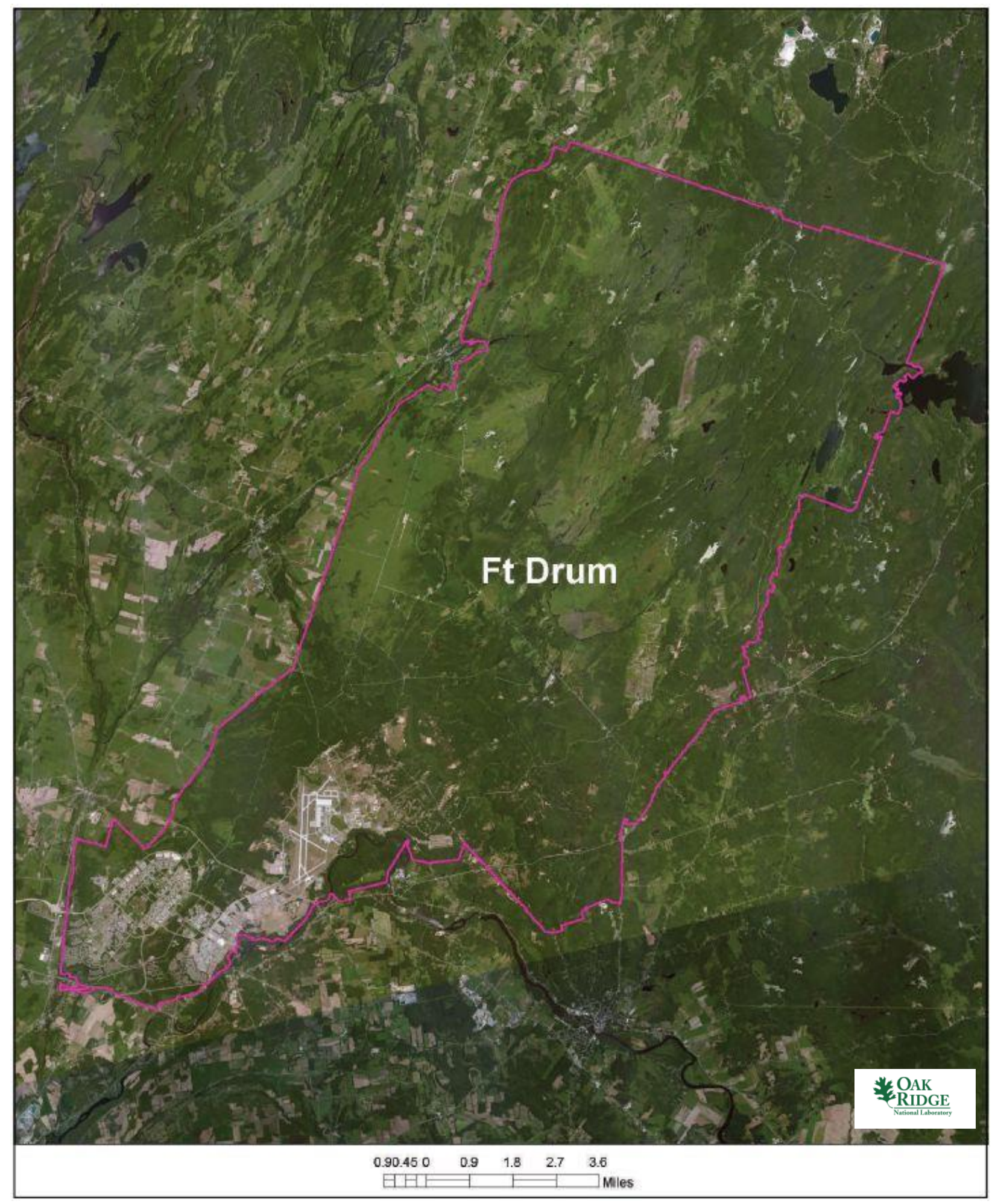

Fig. A.17. Satellite view of Fort Drum area. 


\section{A.6.4 Screening Criteria Overview}

Table A.12 shows a screening criteria summary bar, or "dashboard" chart, for the site area provides a quick look at what siting issues may exist for the site. The criteria that are not met within the site area indicated.

Table A.12. Fort Drum siting criteria summary

\section{Screening Criteria Summary Bar}

(Colored Boxes indicate Screening Results)

\begin{tabular}{|c|c|c|c|c|c|c|c|c|c|c|}
\hline \multicolumn{3}{|c|}{ No Siting Issue } & & & \multicolumn{2}{|c|}{ Partial Siting Issue } & & \multicolumn{3}{|c|}{ Full Siting Issue } \\
\hline $\begin{array}{l}\text { Inside } \\
\text { Military } \\
\text { Base }\end{array}$ & Population & Slope & SSE & $\begin{array}{l}\text { Stream } \\
\text { flow } \\
(65,000 \\
\mathrm{gpm})\end{array}$ & $\begin{array}{l}\text { Proximity } \\
\text { to } \\
\text { Hazard } \\
\text { Operations }\end{array}$ & $\begin{array}{l}\text { Proximity } \\
\text { to } \\
\text { Fault } \\
\text { Lines }\end{array}$ & $\begin{array}{l}\text { Wetlands } \\
\text { Open } \\
\text { Water }\end{array}$ & $\begin{array}{l}100 \text {-year } \\
\text { Flood- } \\
\text { plain }\end{array}$ & $\begin{array}{l}\text { Protected } \\
\text { Lands }\end{array}$ & $\begin{array}{l}\text { Landslide } \\
\text { Hazards }\end{array}$ \\
\hline
\end{tabular}

\begin{tabular}{|l|l|}
\hline \multicolumn{2}{|c|}{ Screening Criteria Table } \\
\hline \multicolumn{1}{|c|}{ Criteria } & Value \\
\hline Population Density within 10 miles (people/square mile) & $>500$ \\
\hline Slope & $>18 \%$ \\
\hline Safe shutdown earthquake (ground acceleration) & $>0.5$ \\
\hline Streamflow/cooling water make-up (gpm) & $<65,000$ \\
\hline Proximity to hazardous operations - buffer (mile) & Depends on hazardous operation ${ }^{1}$ \\
\hline Proximity to fault lines - buffer (mile) & Depends on length of fault \\
\hline Wetlands/Open Water & - \\
\hline 100-year floodplain & - \\
\hline Protected lands & \\
\hline Landslide hazard (moderate and high) & - \\
\hline
\end{tabular}

${ }^{1}$ Hazardous facilities (airports- 5 miles and oil refineries- -1 mile) 


\section{A.6.5 Composite Map and Individual Siting Issue Maps}

A composite map of SMR siting challenges to the Fort Drum is shown in Fig. A.18. Siting challenges are predominantly in the southwest area of the base. Following this map are maps of the individual SMR siting criteria based on selected input values.

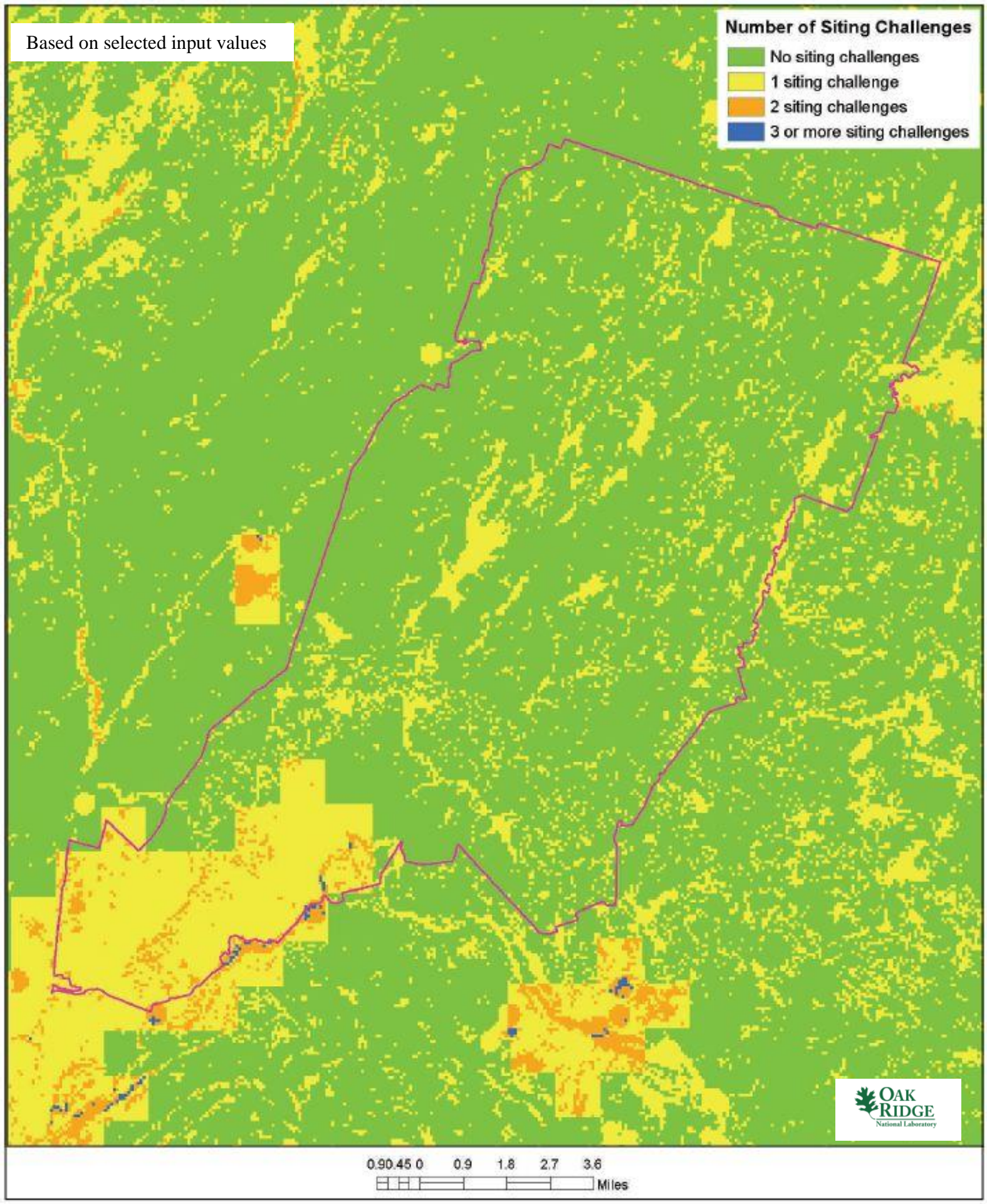

Fig. A.18. Fort Drum composite map. 

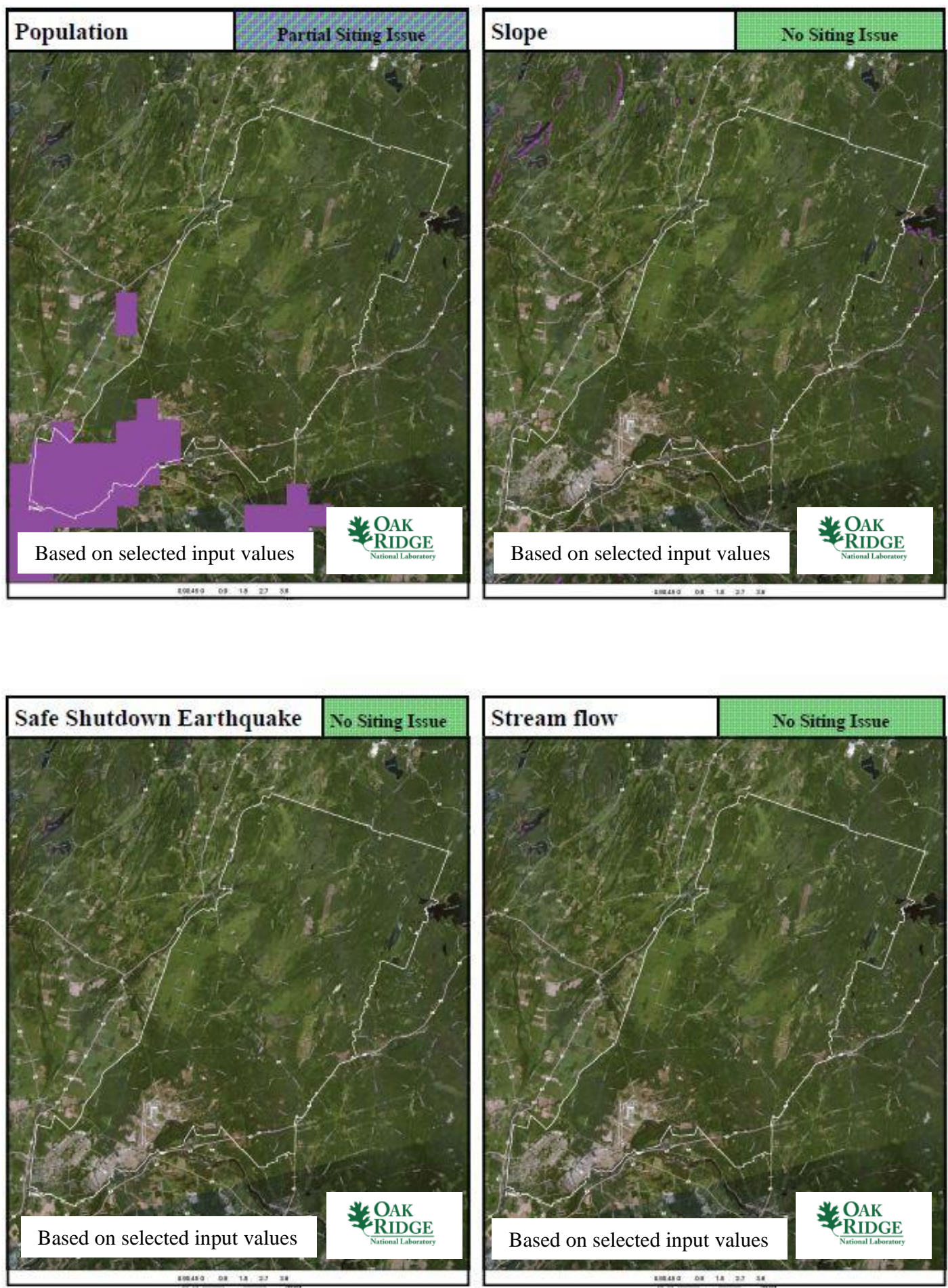

Fort Drum 

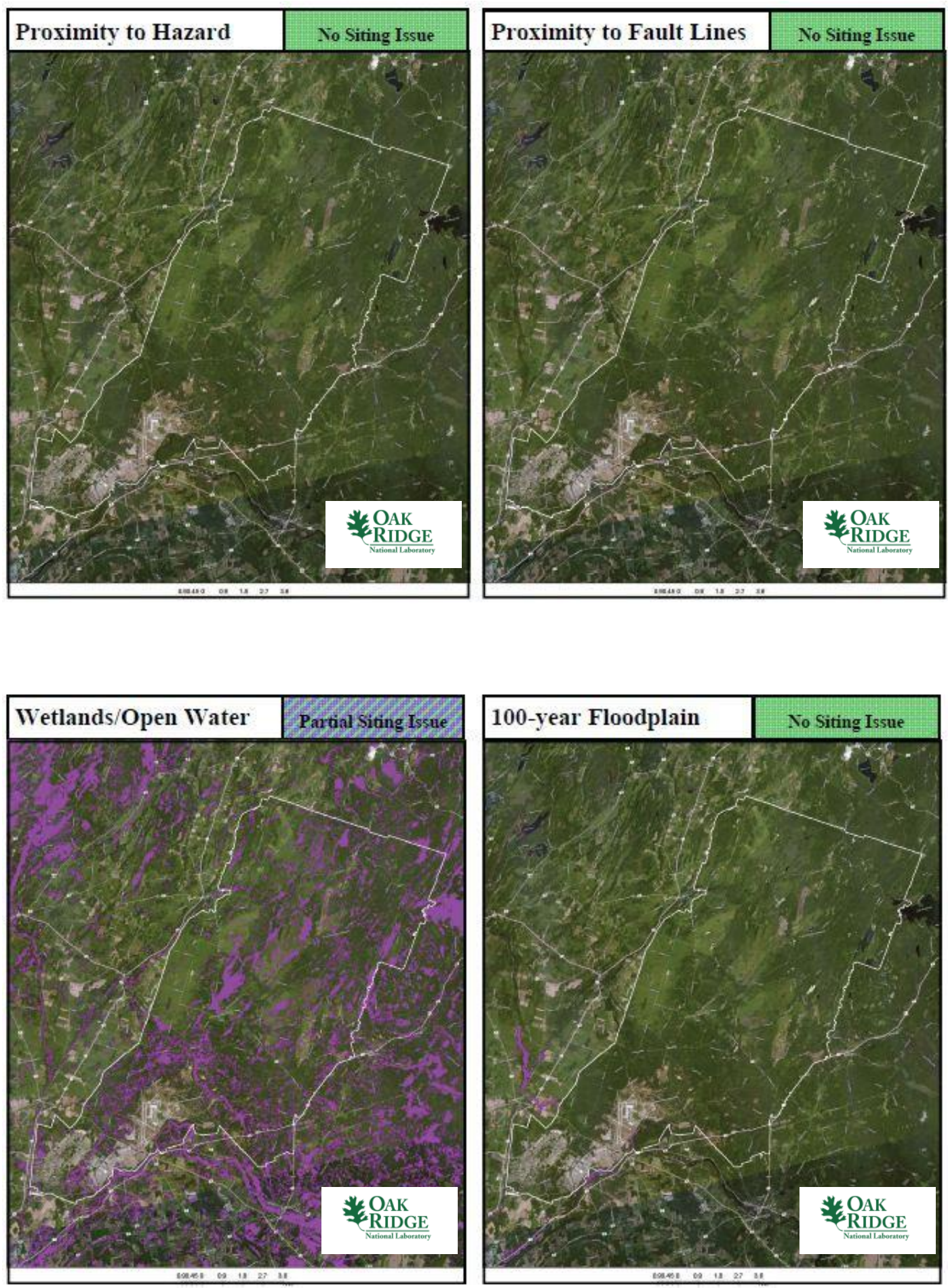

Fort Drum 

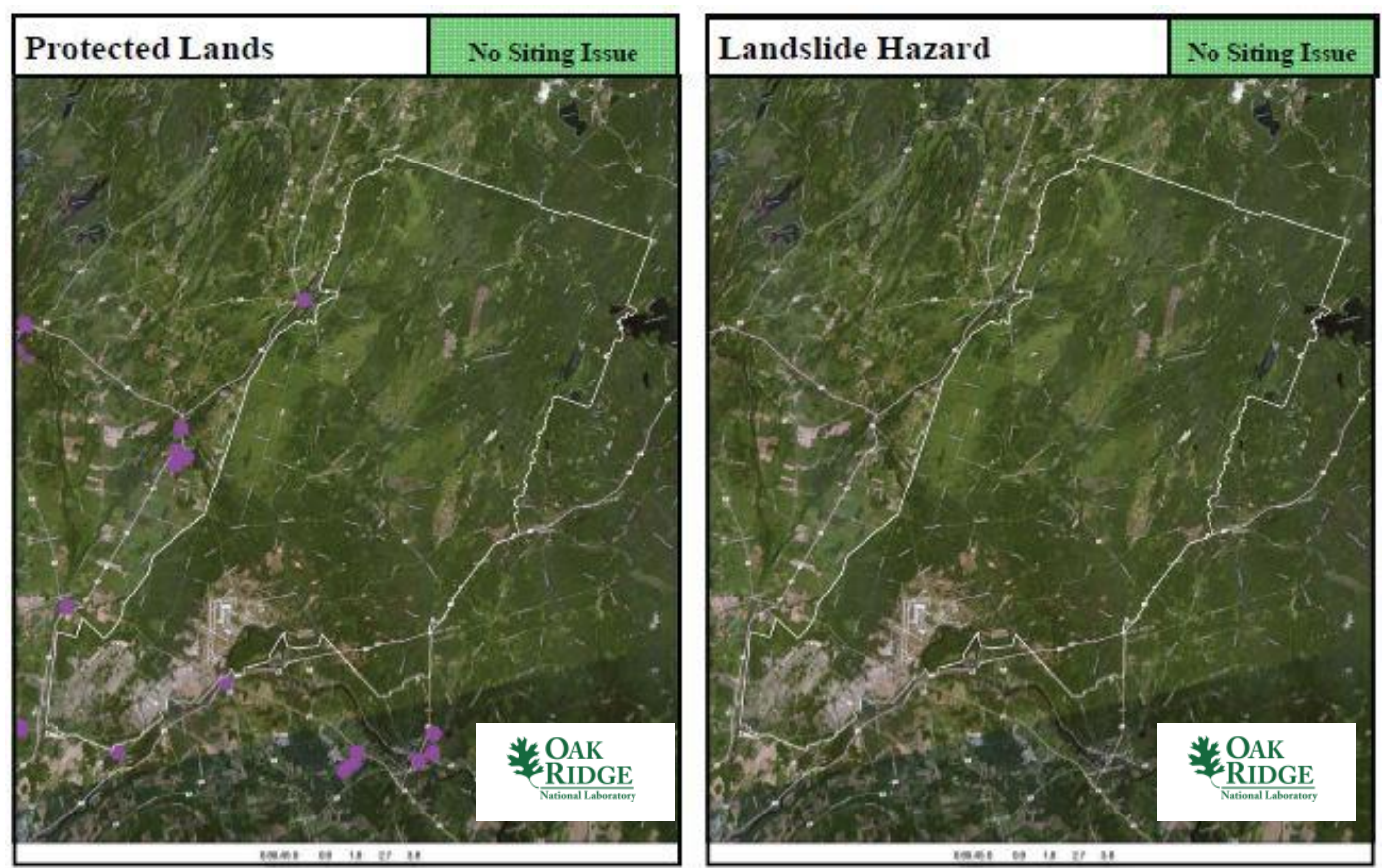

Fort Drum

\section{A.6.6 Site Evaluation}

Fort Drum is a large, federally controlled site. A well-trained, well-armed security force is available. Many of the activities and missions carried out on this base are high technology, mechanized endeavors. Personnel living or working on the base would have considerable familiarity with the technology- and security-related operations associated with nuclear power plant operation. Power demands on the base associated with the military missions and local infrastructure for current residents and workers would also be considerable and feasible for a site-located SMR.

As shown in Sects. A.6.4 and A.6.5, the Fort Drum site has partial site issues with wetlands/open water and the population. ${ }^{1}$ This wetlands/open water concern affects areas across the site, while the population concern is confined to areas in the south of the site. Approximately $75 \%$ of the 97,000 -acre site meets multiple conventional standards for consideration of siting an SMR on the base facility. Note, however, that the composite map does not reflect specific hazards associated with the site, such as ordnance storage areas, weapons ranges, etc., that could render some areas of significant size as unsuitable for siting a reactor.

The site meets current NRC RG 4.7 recommendations for population density without additional consideration for relaxed SMR population siting requirements based on reduced source term. This site should be classified as favorable for siting an SMR. 


\section{A.7 FORT HOOD}

\section{A.7.1 Location Detail}

As shown in Fig. A.19, Fort Hood is located on about 193,000 acres $^{6}$ (about 300 square miles) in Bell County and Coryell County in central Texas between Killeen and Copperas Cove. It is approximately 60 miles north of Austin, 50 miles south of Waco, 160 miles south of Dallas. Fort Hood is home to the III Corps, 1st Calvary Division, 13th Sustainment Command, First Army Division West, 3rd Armored Cavalry Regiment, 41 Fires Brigade and many other corps, units, and agencies. Highway 190 provides four-lane access to the past from Interstate 35, which is located approximately 20 miles to the east of the main population center of the post.

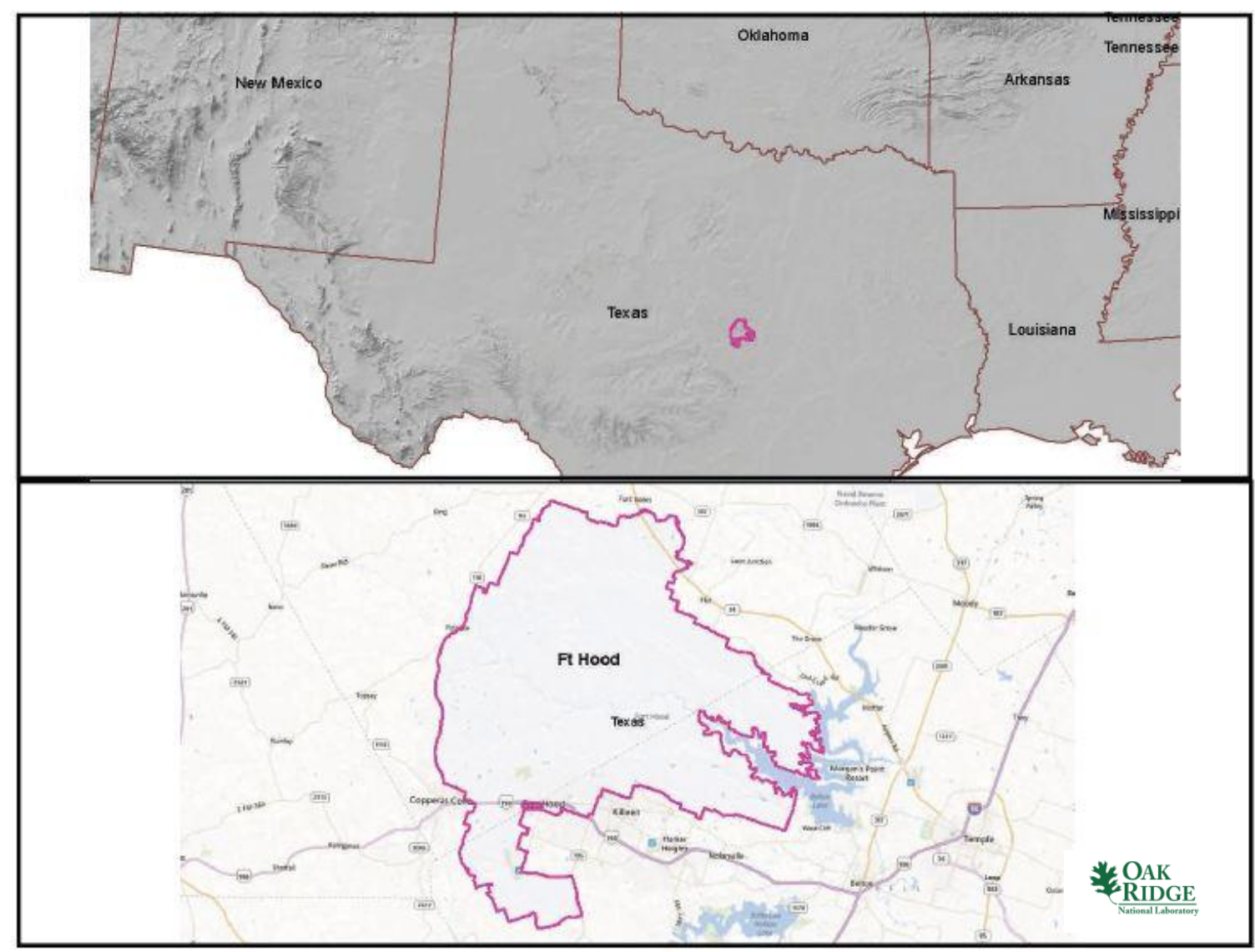

Fig. A.19. Fort Hood.

\section{A.7.2 Site Description and Status}

The III Corps, 1st Calvary Division, 13th Sustainment Command, First Army Division West, 3rd Armored Cavalry Regiment, 41 Fires Brigade and many other corps, units, and agencies are located at Fort Hood. The area is characterized as a "hills and lakes" area. The population served is about 220,000. There are about 50,000 active duty service men and women, approximately 18,000 family members live on post. ${ }^{30}$ Descriptions of the installation, missions, and base history are readily available on the Internet. ${ }^{31,32}$. Services and resources are available on the base for military staff, families, employees, and

\footnotetext{
${ }^{30}$ http://www.hood.army.mil/facts/FS\%200702\%20-\%20Fort\%20Hood\%20Quick\%20Facts.pdf

${ }^{31} \mathrm{http}: / /$ www.hood.army.mil/
} 
services contractors similar to a small town, including lodging and housing, schools, hospital, various shopping facilities, restaurants, library, cultural and recreational amenities, and many other goods and services. $^{33}$

As noted in Table A.13, the nearest major fault line based on USGS data is noted to be 200 miles north in Oklahoma. The maximum safe shutdown earthquake for the site is below $0.3 \mathrm{~g}$ peak ground acceleration. The maximum slope on the site is about $30 \%$. Greater than $200,000 \mathrm{gpm}$ of cooling water makeup is available from the Leon River.

Table A.13. Fort Hood site statistics

\begin{tabular}{|c|c|c|c|}
\hline \multicolumn{2}{|l|}{$\begin{array}{l}\text { Population } \\
\text { Population Within }\end{array}$} & \multicolumn{2}{|l|}{$\begin{array}{l}\text { Utility } \\
\text { Distance to Grid Capacity }\end{array}$} \\
\hline $0.5 \mathrm{mi}$ of Site Boundary & $\sim 275,000$ & $>400 \mathrm{MWe}$ & $\sim 34 \mathrm{mi}$ \\
\hline $1 \mathrm{mi}$ of Site Boundary & $\sim 332,000$ & $>800 \mathrm{MWe}$ & $\sim 34 \mathrm{mi}$ \\
\hline $5 \mathrm{mi}$ of Site Boundary & $\sim 593,000$ & $>1600 \mathrm{MWe}$ & $\sim 77 \mathrm{mi}$ \\
\hline $10 \mathrm{mi}$ of Site Boundary & $\sim 820,000$ & $>3200 \mathrm{MWe}$ & $\sim 708 \mathrm{mi}$ \\
\hline \multicolumn{2}{|c|}{ Nearest City with Population } & \multicolumn{2}{|c|}{ Distance to Cooling Water } \\
\hline$>10,000$ & Copperas Cove, TX & $>50,000 \mathrm{gpm}$ & $\sim 0.1 \mathrm{mi}$ (Fish Stream) \\
\hline$>50,000$ & Temple, TX & $>100,000 \mathrm{gpm}$ & $\sim 0.1 \mathrm{mi}$ (Leon River) \\
\hline$>100,000$ & Kileen, TX & $>200,000 \mathrm{gpm}$ & $\sim 0.1 \mathrm{mi}$ (Leon River) \\
\hline$>500,000$ & Austin, TX & $>500,000 \mathrm{gpm}$ & $\sim 33 \mathrm{mi}$ (Colorado River) \\
\hline \multicolumn{2}{|l|}{ Geotechnical } & \multicolumn{2}{|l|}{ Accessibility } \\
\hline Max Earthquake Acceleration & $<0.3 \mathrm{~g}$ & Distance to Major Roadway & $\sim 6$ mi (Interstate 35 ) \\
\hline Max Slope & $\sim 30 \%$ & Distance to Water Transport & $\sim 153 \mathrm{mi}$ (Pacific Deep) \\
\hline Nearest Fault Line & $\sim 219 \mathrm{mi}$ (Oklahoma) & Distance to Rail Transport & $\sim 0.1 \mathrm{mi}(\mathrm{BNSF})$ \\
\hline Nearest Hazard Site & $\begin{array}{l}\text { On Site (Airport- } \\
\text { Robert Gray AAF) }\end{array}$ & Distance to Airport & $\begin{array}{c}\text { On Site (Robert Gray } \\
\text { AAF) }\end{array}$ \\
\hline
\end{tabular}

\section{A.7.3 Aerial Imagery}

The aerial imagery in Fig. A.20 indicates the areas of population density in the south-central area of the base. Numerous base facilities, buildings, ranges, and training areas are located on this large site. The Killeen-Fort Hood Regional Airport is located in the southwest part of the base.

\footnotetext{
${ }^{32} \mathrm{http}: / /$ en.wikipedia.org/wiki/Fort_Hood

${ }^{33} \mathrm{http}: / /$ www.mybaseguide.com/article/military/ft-hood/515/Welcome
} 


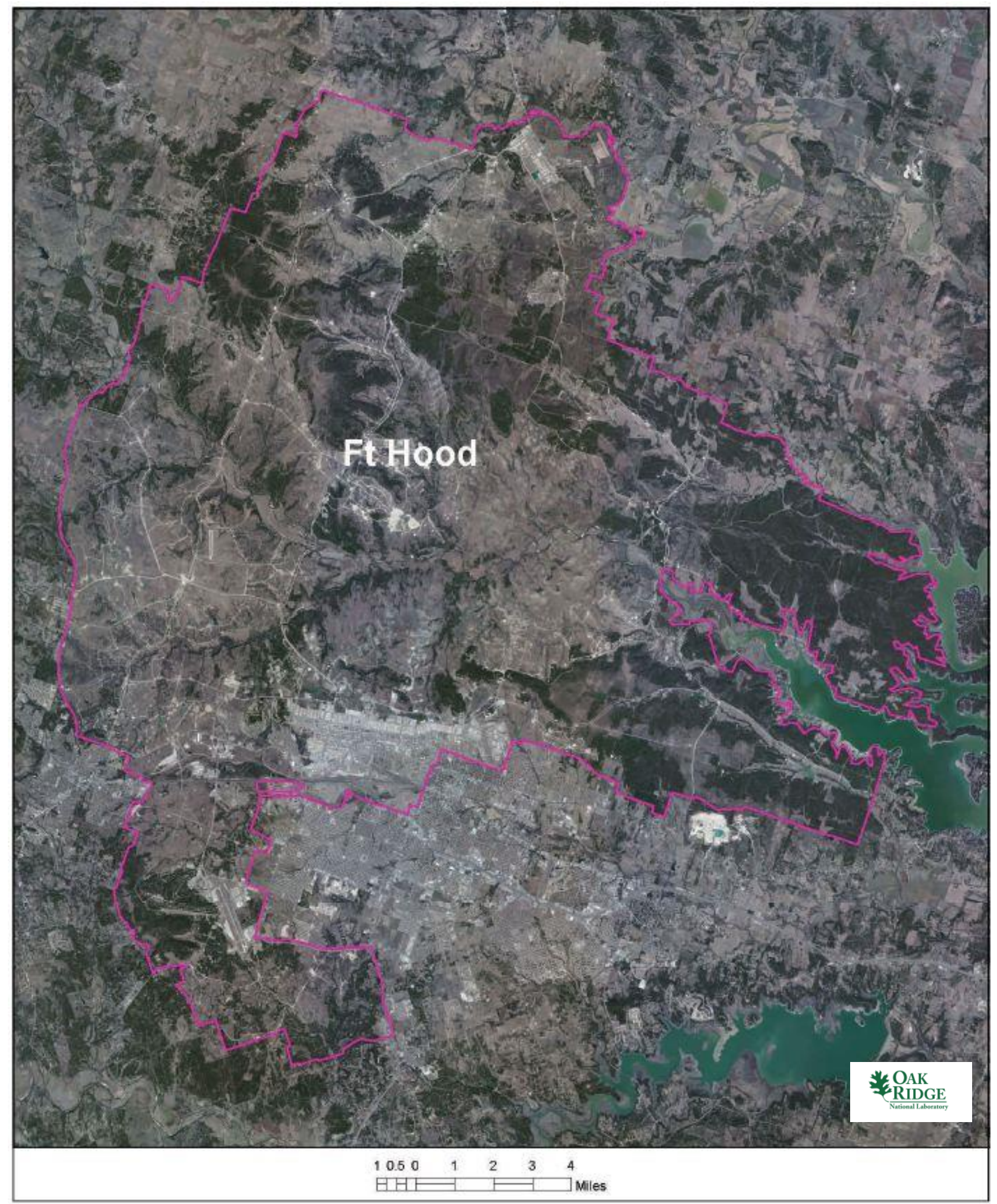

Fig. A.20. Satellite view of Fort Hood area. 


\section{A.7.4 Screening Criteria Overview}

Table A.14 shows a screening criteria summary bar, or "dashboard" chart, for the site area provides a quick look at what siting issues may exist for the site. The criteria that are not met within the site area indicated.

Table A.14. Fort Hood siting criteria summary

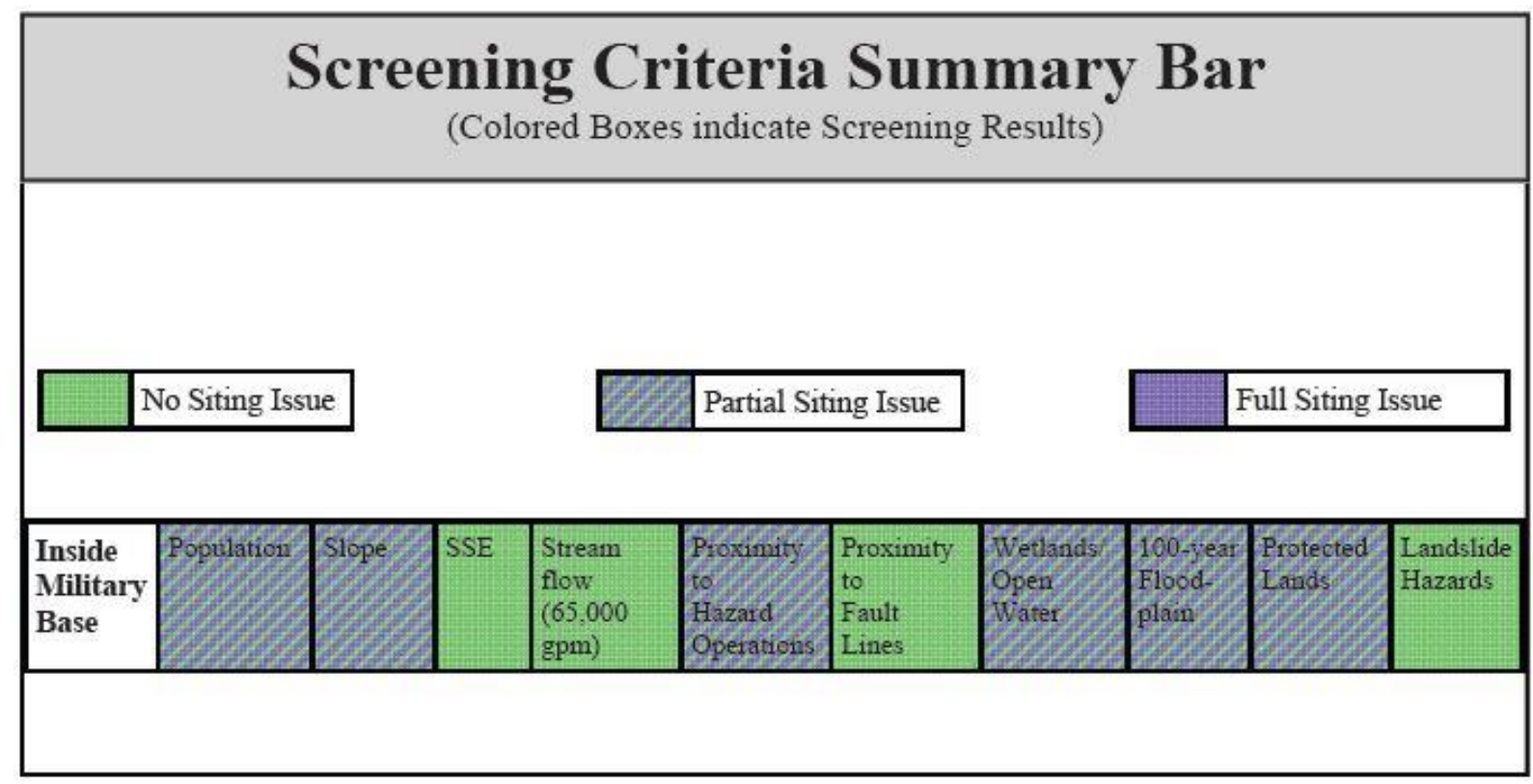

\begin{tabular}{|l|c|}
\hline \multicolumn{2}{|c|}{ Screening Criteria Table } \\
\hline \multicolumn{1}{|c|}{ Criteria } & Value \\
\hline Population Density within 10 miles (people/square mile) & $>500$ \\
\hline Slope & $>18 \%$ \\
\hline Safe shutdown earthquake (ground acceleration) & $>0.5$ \\
\hline Streamflow/cooling water make-up (gpm) & $<65,000$ \\
\hline Proximity to hazardous operations - buffer (mile) & Depends on hazardous operation ${ }^{1}$ \\
\hline Proximity to fault lines - buffer (mile) & Depends on length of fault \\
\hline Wetlands/Open Water & - \\
\hline 100 -year floodplain & - \\
\hline Protected lands & - \\
\hline Landslide hazard (moderate and high) & - \\
\hline
\end{tabular}

${ }^{1}$ Hazardous facilities (airports- 5 miles and oil refineries -1 mile) 


\section{A.7.5 Composite Map and Individual Siting Issue Maps}

A composite map of SMR siting challenges to the Fort Hood is shown in Fig. A.21. Siting challenges are predominantly in the southernmost and eastern areas of the post. Following this map are maps of the individual SMR siting criteria based on selected input values.

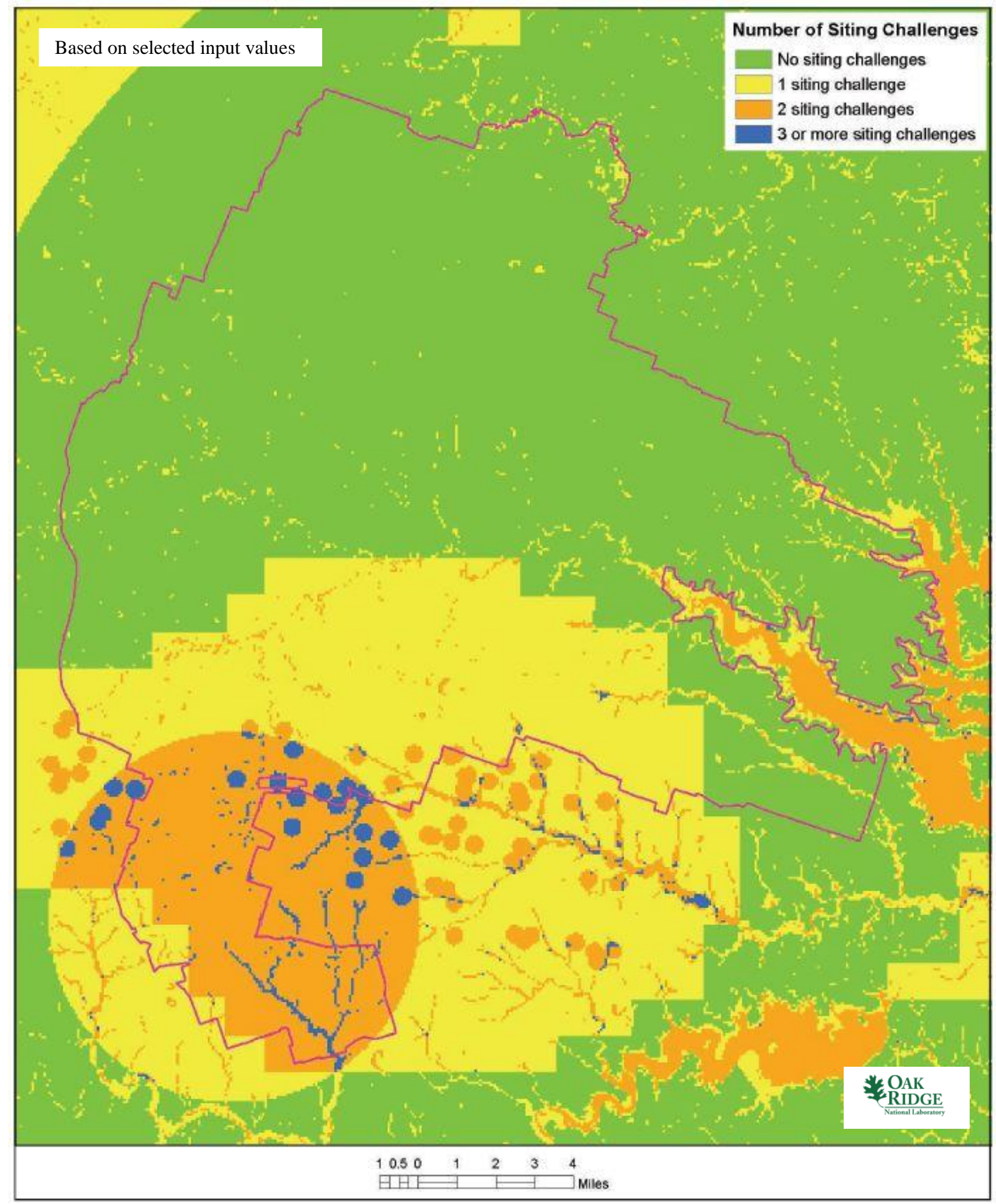

Fig. A.21. Fort Hood composite map. 

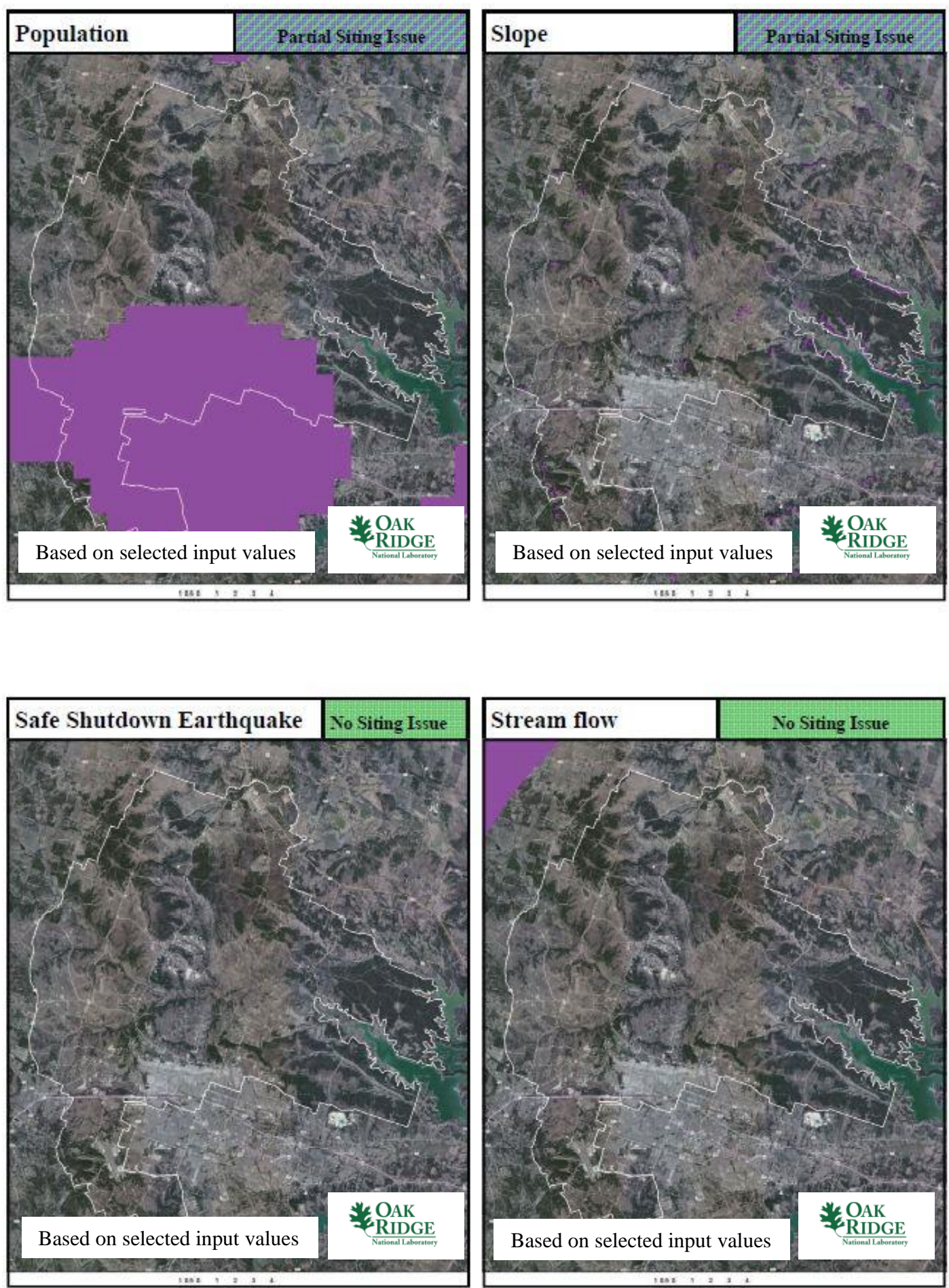

Fort Hood 

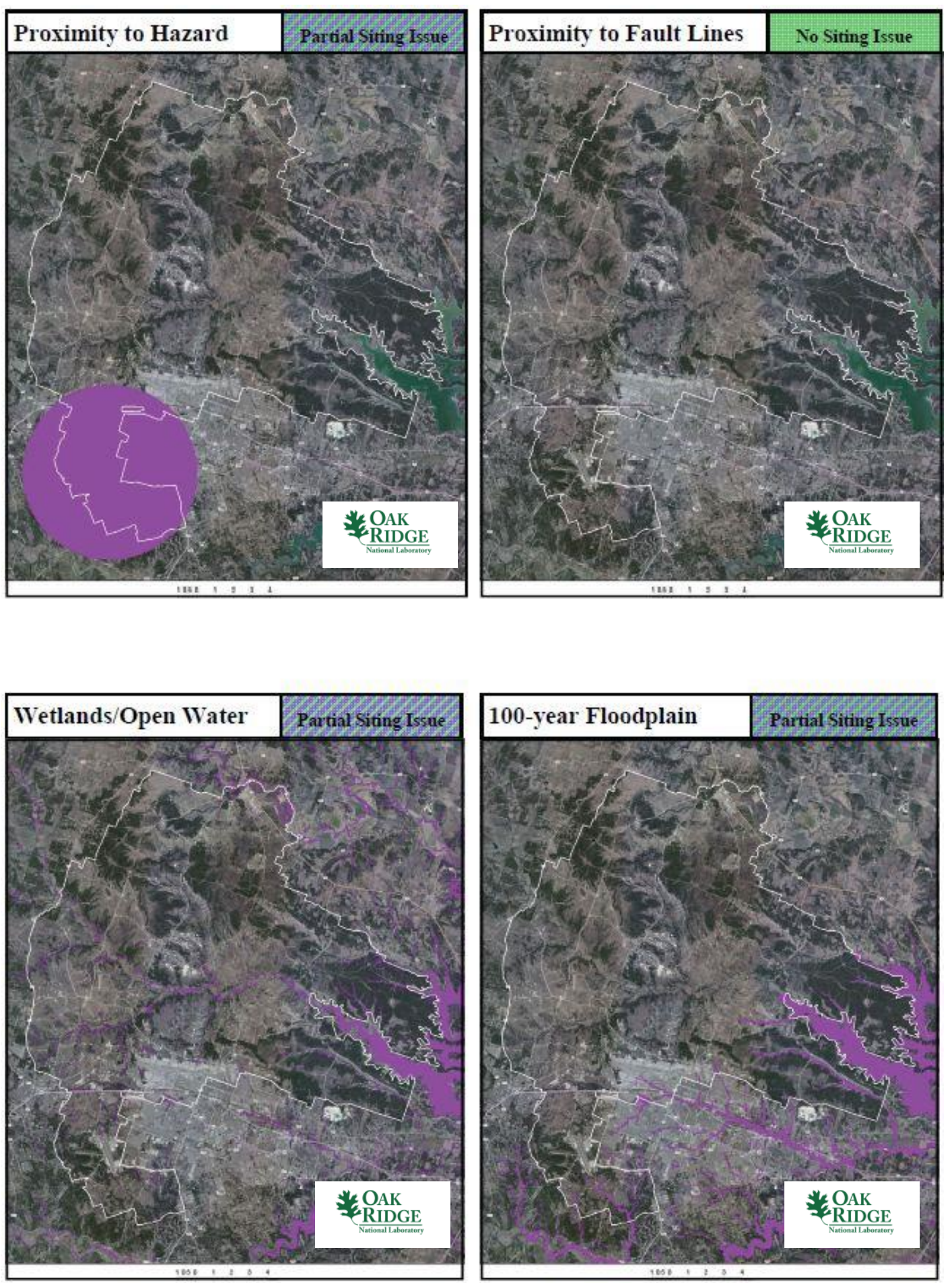

Fort Hood 

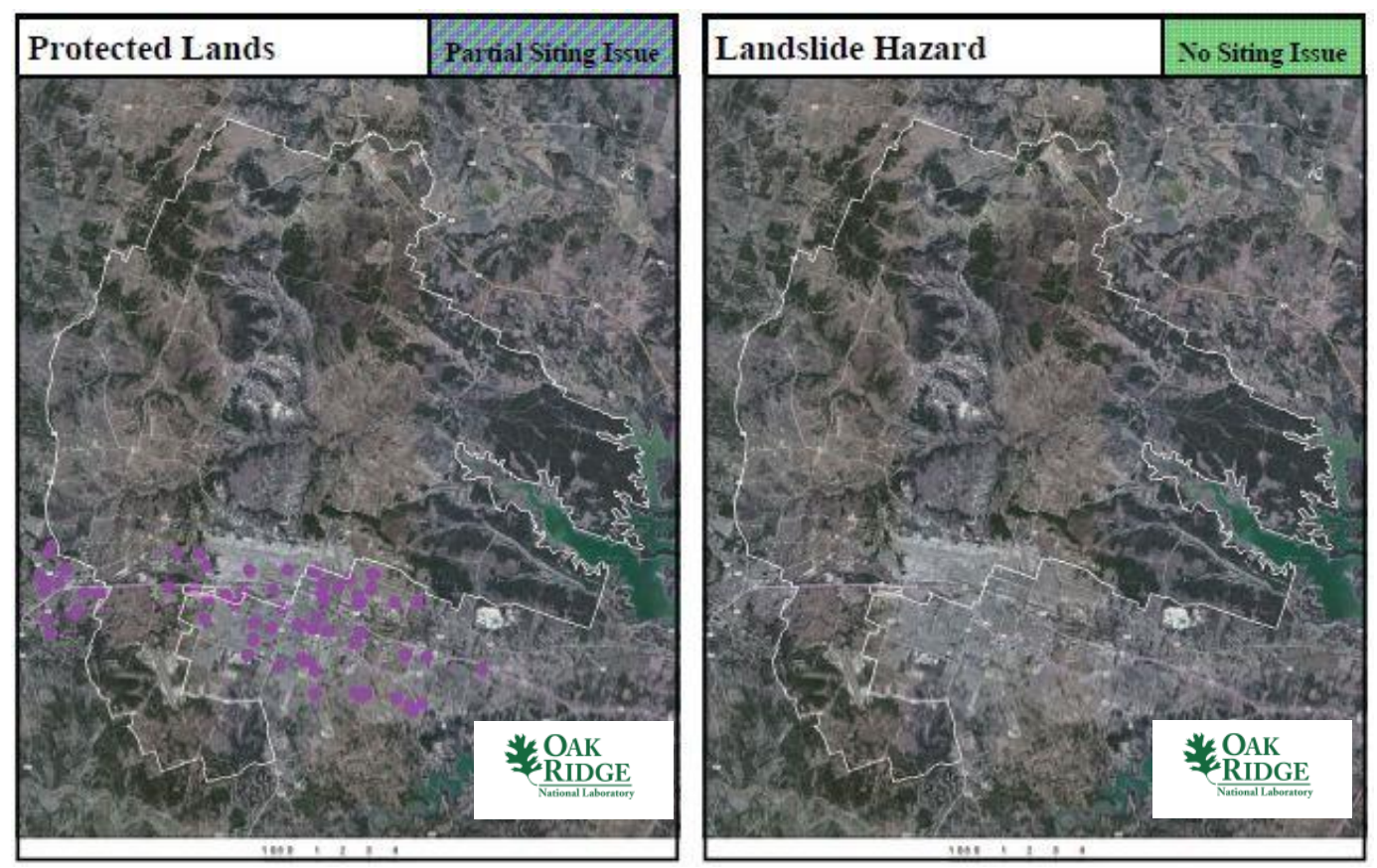

Fort Hood

\section{A.7.6 Site Evaluation}

Fort Hood is a large, federally controlled site. A well-trained, well-armed security force is available. Many of the activities and missions carried out on this base are high technology, mechanized endeavors. Personnel living or working on the base would have considerable familiarity with the technology- and security-related operations associated with nuclear power plant operation. Power demands on the base associated with the military missions and local infrastructure for current residents and workers would also be considerable and feasible for a site-located SMR.

As shown in Sects. A.7.4 and A.7.5, the Fort Hood site has partial site issues with multiple SMR SSEC. ${ }^{1}$ These concerns are confined to areas in the south of the site. Approximately $66 \%$ of the 193,000 -acre site meets multiple conventional standards for consideration of siting an SMR on the base facility. Note, however, that the composite map does not reflect specific hazards associated with the site, such as ordnance storage areas, weapons ranges, etc., that could render some areas of significant size as unsuitable for siting a reactor.

The site meets current NRC RG 4.7 recommendations for population density without additional consideration for relaxed SMR population siting requirements based on reduced source term. This site should be classified as favorable for siting an SMR. 


\section{A.8 FORT POLK}

\section{A.8.1 Location Detail}

As shown in Fig. A.22, Fort Polk is located on about 180,000 acres $^{6}$ (about 280 square miles) is in westcentral Louisiana. Approximately 100,000 acres is owned by the army and about 80,000 acres is US Forest Service land. The Fort Polk cantonment is about 10 miles southeast of Lessville, Louisiana, and about 50 miles southwest of Alexandria, Louisiana. Fort Polk is home to the Joint Readiness Training Center (JRTC), the 4th Brigade, 10th Mountain Division, 115th Combat Support Hospital,1st Maneuver Enhancement Brigade, the 162nd Infantry Brigade and other elements. Pitkin Highway passes the southwest area of the base in the Fort Polk South area. Highway 28 passes north of the Fort Polk South and Fort Polk North areas. Interstate 49 is about 30 miles east of this main base area and just several miles away from the northern area of the base.

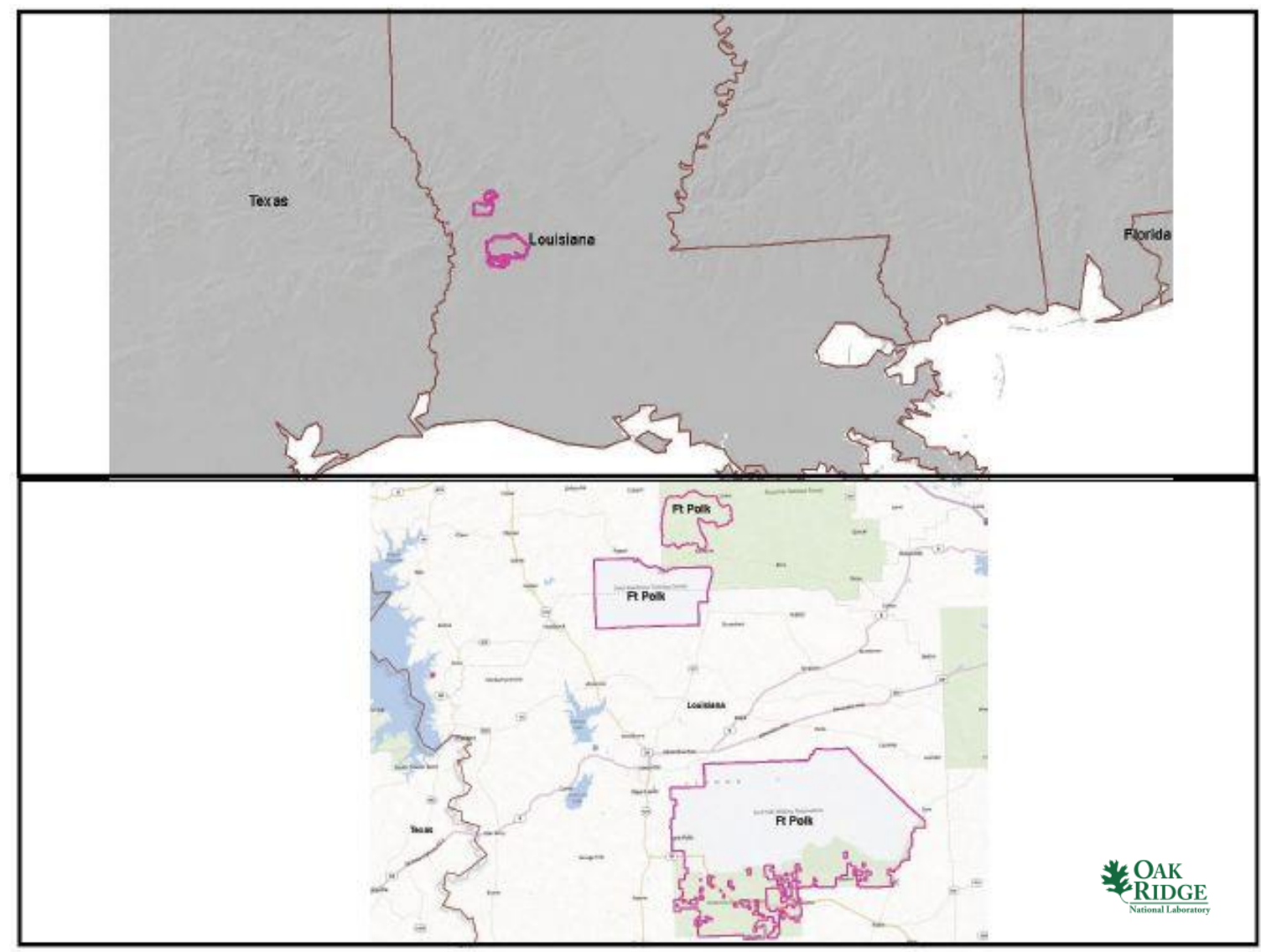

Fig. A.22. Fort Polk.

\section{A.8.2 Site Description and Status}

The Joint Readiness Training Center (JRTC), the 4th Brigade, 10th Mountain Division, 115th Combat Support Hospital,1st Maneuver Enhancement Brigade, the 162nd Infantry Brigade and other elements are located at Fort Polk. 
Approximately, 17,000 soldiers, employees, families, and contractors are on-site at any given time. ${ }^{34}$ Descriptions of the installation, missions, and base history are readily available on the Internet. ${ }^{35,36}$

Services and resources are available on the base for military staff, families, employees, and services contractors similar to a small town, including lodging and housing, hospital, various shopping facilities, restaurants, library, cultural and recreational amenities, and many other goods and services. ${ }^{37}$

As noted in Table A.15, the nearest major fault line based on USGS data is noted to be 343 miles northwest in Oklahoma. The maximum safe shutdown earthquake for the site is below $0.3 \mathrm{~g}$ peak ground acceleration. The maximum slope on the site is about $15 \%$. Greater than 500,000 gpm of cooling water makeup is available from the Sabine River west of the base. Major highways, water transport, and rail transport are nearby.

Table A.15. Fort Polk site statistics

\begin{tabular}{|c|c|c|c|}
\hline \multicolumn{2}{|l|}{$\begin{array}{l}\text { Population } \\
\text { Population Within }\end{array}$} & \multicolumn{2}{|l|}{$\begin{array}{l}\text { Utility } \\
\text { Distance to Grid Capacity }\end{array}$} \\
\hline $0.5 \mathrm{mi}$ of Site Boundary & $\sim 50,500$ & $>400 \mathrm{MWe}$ & $\sim 8 \mathrm{mi}$ \\
\hline $1 \mathrm{mi}$ of Site Boundary & $\sim 58,500$ & $>800 \mathrm{MWe}$ & $\sim 0.1 \mathrm{mi}$ \\
\hline $5 \mathrm{mi}$ of Site Boundary & $\sim 115,000$ & $>1600 \mathrm{MWe}$ & $\sim 87 \mathrm{mi}$ \\
\hline $10 \mathrm{mi}$ of Site Boundary & $\sim 193,500$ & $>3200 \mathrm{MWe}$ & $\sim 462 \mathrm{mi}$ \\
\hline \multicolumn{2}{|c|}{ Nearest City with Population } & \multicolumn{2}{|c|}{ Distance to Cooling Water } \\
\hline$>10,000$ & Natchitoches, LA & $>50,000 \mathrm{gpm}$ & $\sim 2 \mathrm{mi}$ (Fish Stream) \\
\hline$>50,000$ & Lake Charles, LA & $>100,000 \mathrm{gpm}$ & $\sim 3$ mi (Sabine River) \\
\hline$>100,000$ & Lafayette, LA & $>200,000 \mathrm{gpm}$ & $\sim 3 \mathrm{mi}$ (Sabine River) \\
\hline$>500,000$ & Houston, TX & $>500,000 \mathrm{gpm}$ & $\sim 3$ mi (Sabine River) \\
\hline \multicolumn{2}{|l|}{ Geotechnical } & \multicolumn{2}{|l|}{ Accessibility } \\
\hline Max Earthquake Acceleration & $<0.3 \mathrm{~g}$ & Distance to Major Roadway & $\sim 9 \mathrm{mi}$ (Interstate 49 ) \\
\hline Max Slope & $\sim 15 \%$ & Distance to Water Transport & $\sim 16 \mathrm{mi}$ (Metrofania Bay) \\
\hline Nearest Fault Line & $\sim 343 \mathrm{mi}$ (Oklahoma) & Distance to Rail Transport & $\sim 0.1 \mathrm{mi}$ (USG) \\
\hline Nearest Hazard Site & $\begin{array}{r}\sim 25 \mathrm{mi} \text { (Airport- } \\
\text { Alexandria Int'1) }\end{array}$ & Distance to Airport & $\sim 25 \mathrm{mi}($ Alexandeia Int 1$)$ \\
\hline
\end{tabular}

\section{A.8.3 Aerial Imagery}

The aerial imagery in Fig. A.23 indicates the areas of population density in the west area of the base. Numerous base facilities, buildings, ranges, airfields, and training areas are located on this site.

\footnotetext{
${ }^{34}$ http://www.jrtc-polk.army.mil/Main_Page_Docs/FactSheet.pdf

${ }^{35} \mathrm{http}: / /$ www.jrtc-polk.army.mil/

${ }^{36} \mathrm{http}: / /$ en.wikipedia.org/wiki/Fort_Polk

${ }^{37} \mathrm{http}: / /$ www.jrtc-polk.army.mil/newcomer's_brief.pdf
} 


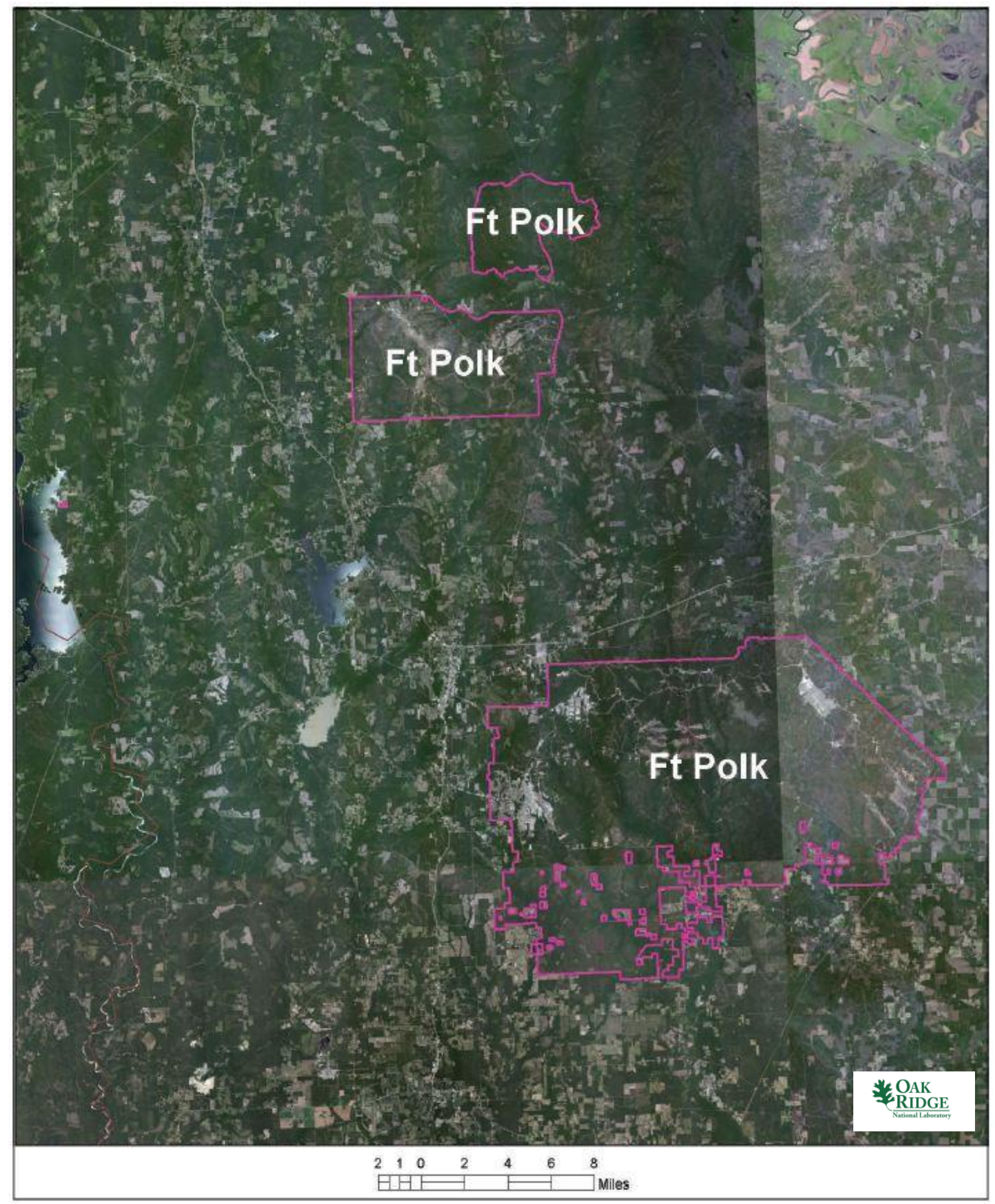

Fig. A.23. Satellite view of Fort Polk area. 


\section{A.8.4 Screening Criteria Overview}

Table A.16 shows a screening criteria summary bar, or "dashboard" chart, for the site area provides a quick look at what siting issues may exist for the site. The criteria that are not met within the site area indicated.

Table A.16. Fort Polk siting criteria summary

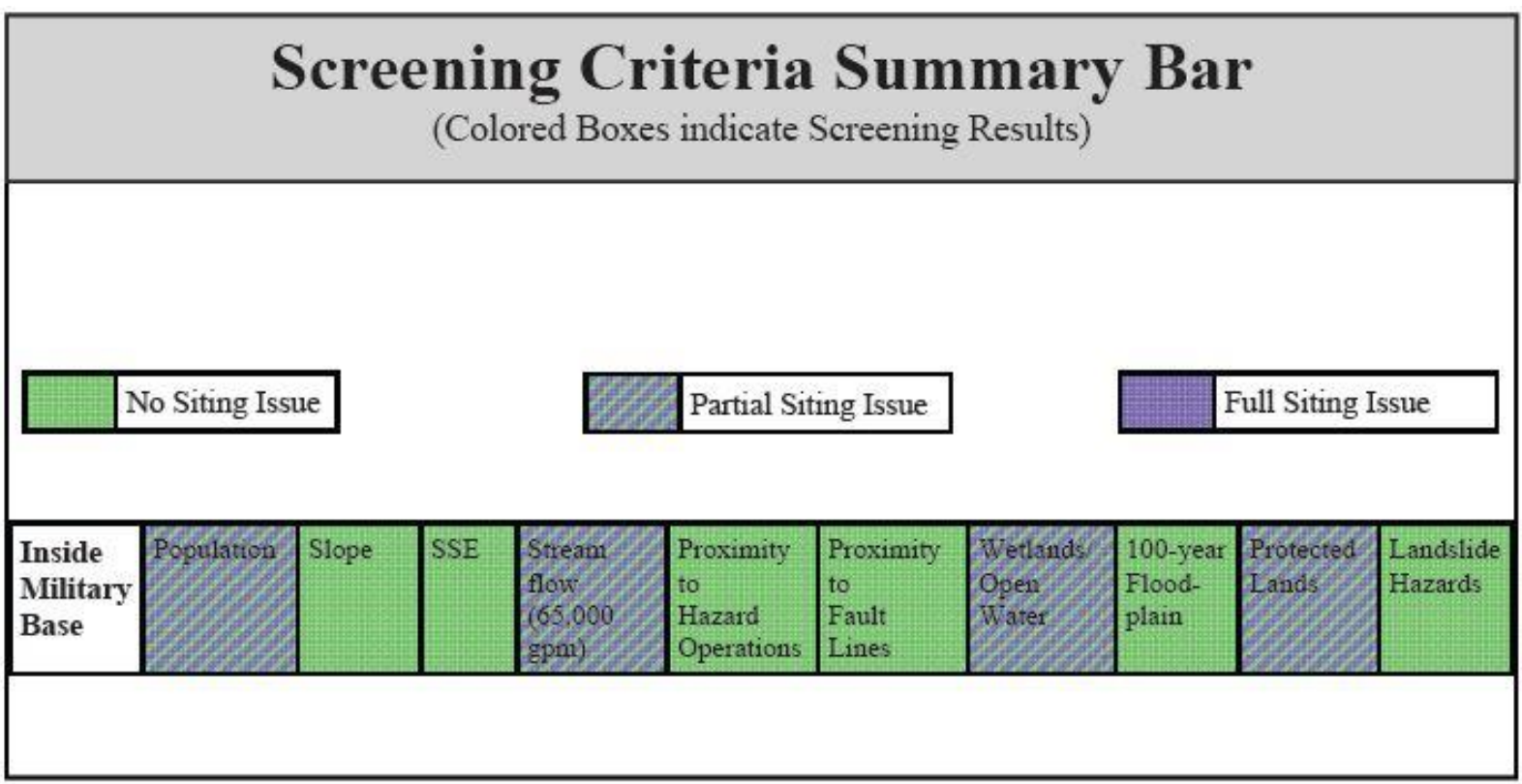

\begin{tabular}{|l|c|}
\hline \multicolumn{2}{|c|}{ Screening Criteria Table } \\
\hline \multicolumn{1}{|c|}{ Criteria } & Value \\
\hline Population Density within 10 miles (people/square mile) & $>500$ \\
\hline Slope & $>18 \%$ \\
\hline Safe shutdown earthquake (ground acceleration) & $>0.5$ \\
\hline Streamflow/cooling water make-up (gpm) & $<65,000$ \\
\hline Proximity to hazardous operations - buffer (mile) & Depends on hazardous operation ${ }^{1}$ \\
\hline Proximity to fault lines - buffer (mile) & Depends on length of fault \\
\hline Wetlands/Open Water & - \\
\hline 100-year floodplain & - \\
\hline Protected lands & - \\
\hline Landslide hazard (moderate and high) & - \\
\hline
\end{tabular}

${ }^{1}$ Hazardous facilities (airports- 5 miles and oil refineries -1 mile) 


\section{A.8.5 Composite Map and Individual Siting Issue Maps}

A composite map of SMR siting challenges to the Fort Polk is shown in Fig. A.24. Siting challenges are predominantly related to population in the western area and stream flow in the eastern area of the largest base area. Wildlife management or Forest Service land is a challenge in the north-most base area. Following this map are maps of the individual SMR siting criteria based on selected input values.

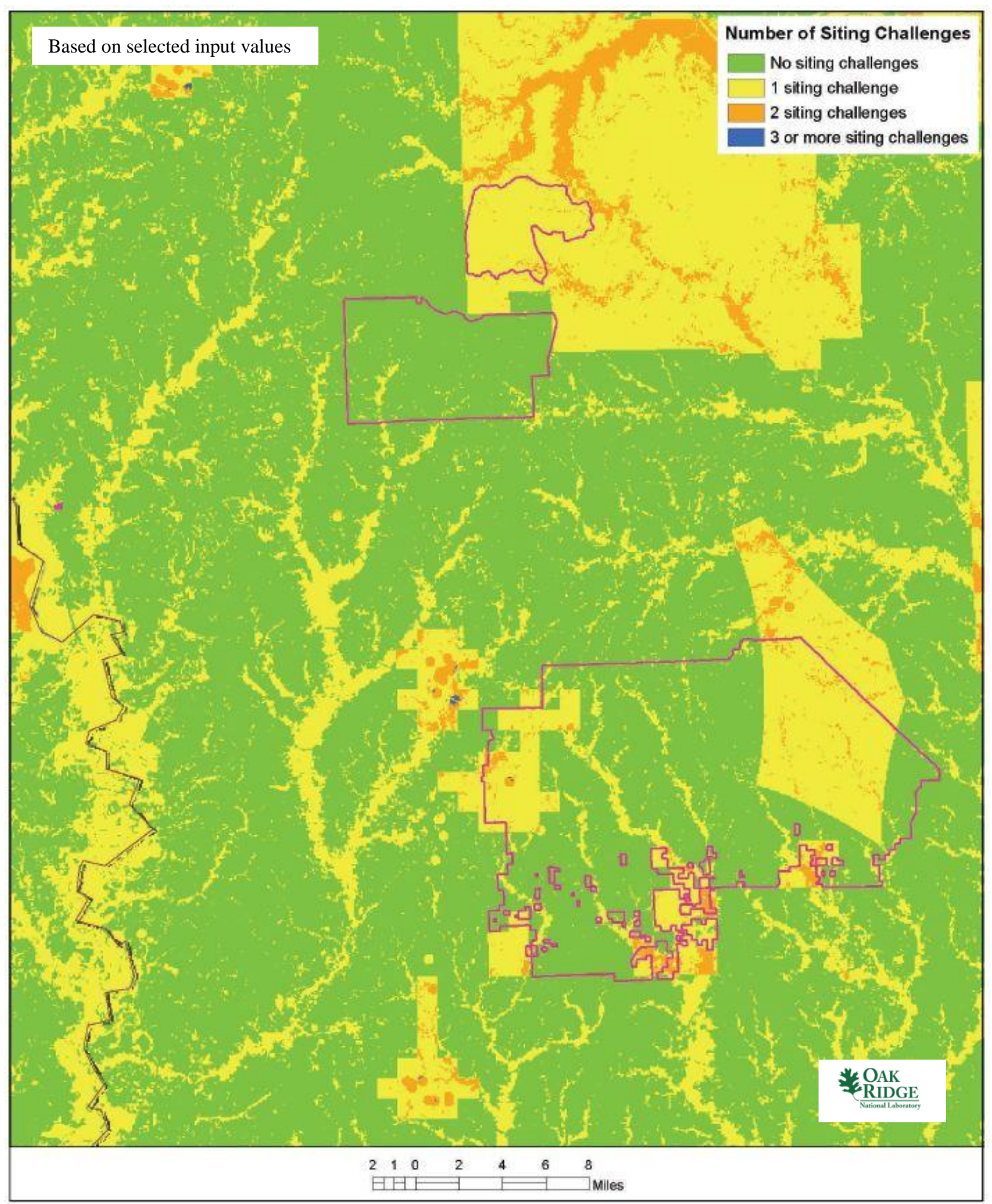

Fig. A.24. Fort Polk composite map. 

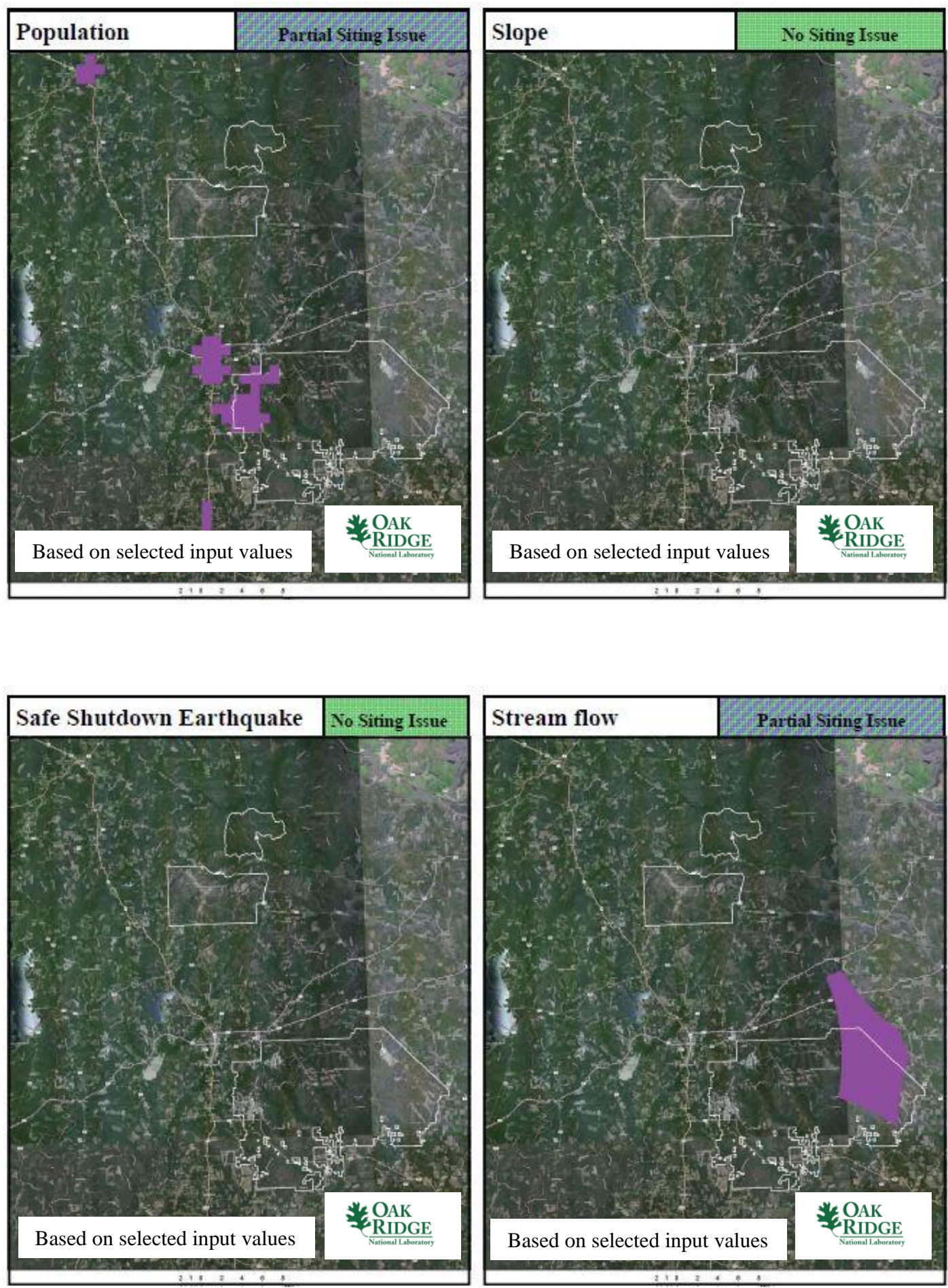

Fort Polk 

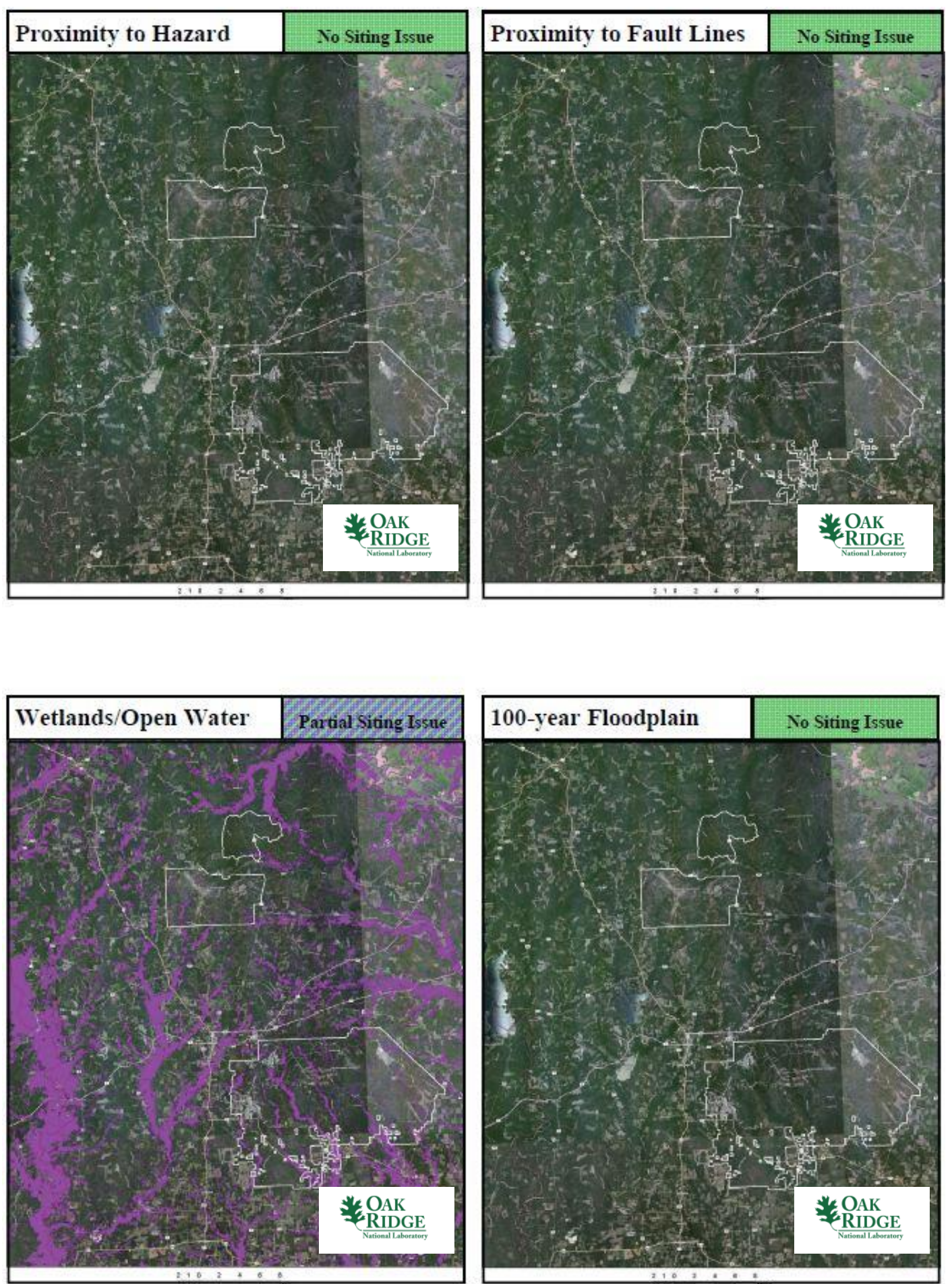

Fort Polk 

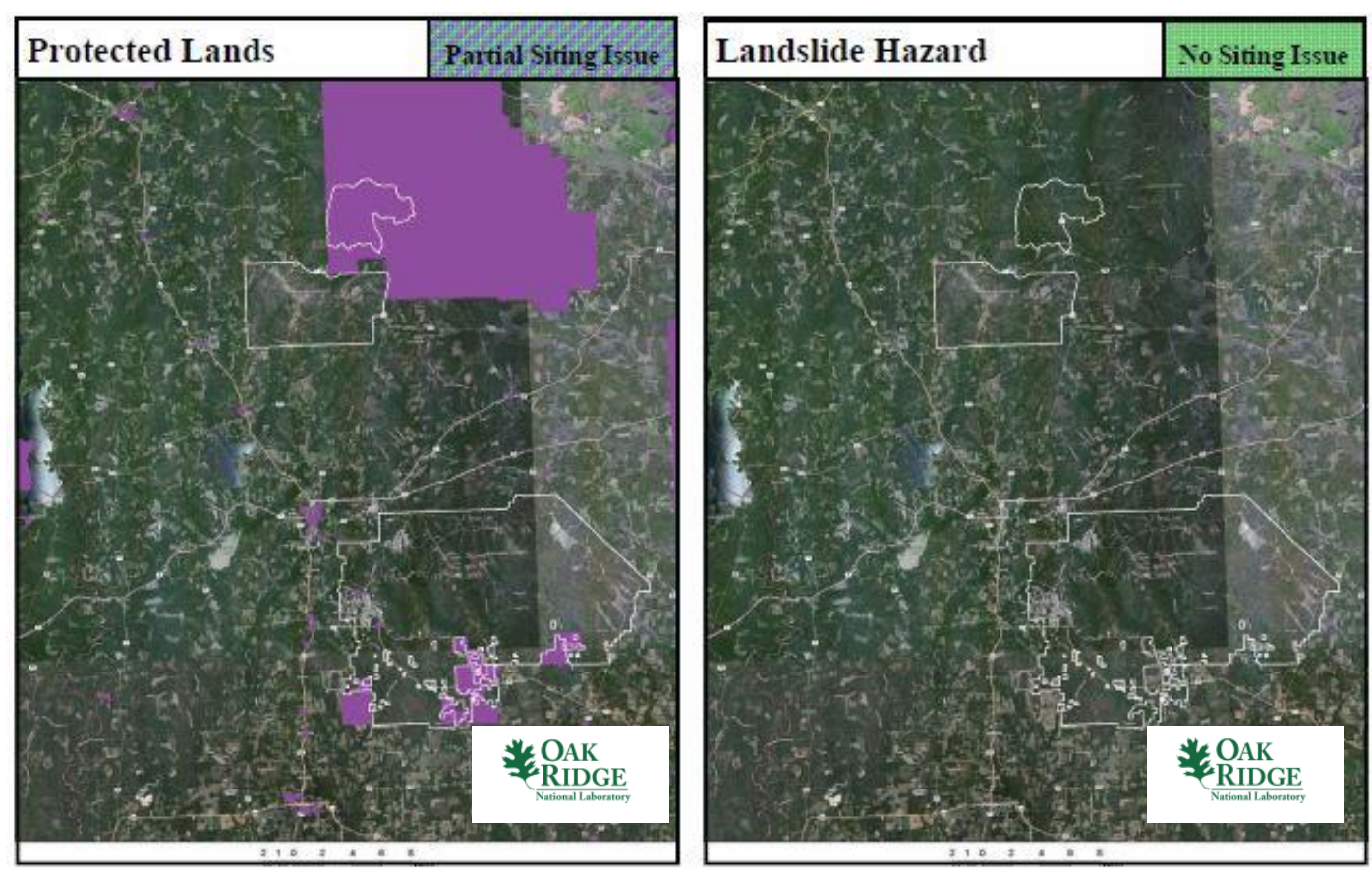

Fort Polk

\section{A.8.6 Site Evaluation}

Fort Polk is a large, federally controlled site. A well-trained, well-armed security force is available. Many of the activities and missions carried out on this base are high technology, mechanized endeavors. Personnel living or working on the base would have considerable familiarity with the technology- and security-related operations associated with nuclear power plant operation. Power demands on the base associated with the military missions and local infrastructure for current residents and workers would also be considerable and feasible for a site-located SMR.

As shown in Sects. A.8.4 and A.8.5, the Fort Polk site has partial site issues with wetlands/open water, protected land and population. ${ }^{1}$ This wetlands/open water concern affects areas across the site, while the population concern is confined to areas in the southern site boundary. Protected land impacts the northern site boundary. Approximately $65 \%$ of the 180,000 -acre site meets multiple conventional standards for consideration of siting an SMR on the base facility. However, two clearly visible airfields in the satellite imagery were not automatically removed from consideration due to the special circumstances of this ORSAGE application. The area around a commercial airport is typically buffered from siting consideration by OR-SAGE to a distance of 5 miles. Military airfields are not considered separately, because military facilities are already an SMR SSEC exclusion factor for commercial SMR siting. As a result, the airfield areas on the base must be considered separately. Excluding land from consideration to a 5-mile radius from the center of the airfields essentially reduces the area suitable for siting an SMR to approximately $40 \%$ of Fort Polk. Note, however, that the composite map does not reflect specific hazards associated with the site, such as ordnance storage areas, weapons ranges, etc., that could render some areas of significant size as unsuitable for siting a reactor.

The site meets current NRC RG 4.7 recommendations for population density without additional consideration for relaxed SMR population siting requirements based on reduced source term. This site should be classified as favorable for siting an SMR. 


\section{A.9 FORT STEWART}

\section{A.9.1 Location Detail}

As shown in Fig. A.25, Fort Stewart is located on about 253,000 acres ${ }^{6}$ (about 395 square miles) in southeast Georgia, in parts of Liberty, Long, Tattnall, Evans, and Bryan counties, about 40 miles southwest of Savannah. Fort Stewart is home to the Hunter Army Airfield Command Group, Kelly Hill Command Group, the 3rd Infantry Division, its heavy, armored forces, and many tenant groups and agencies. The base is about 40 miles across east to west and about 20 miles from north to south.

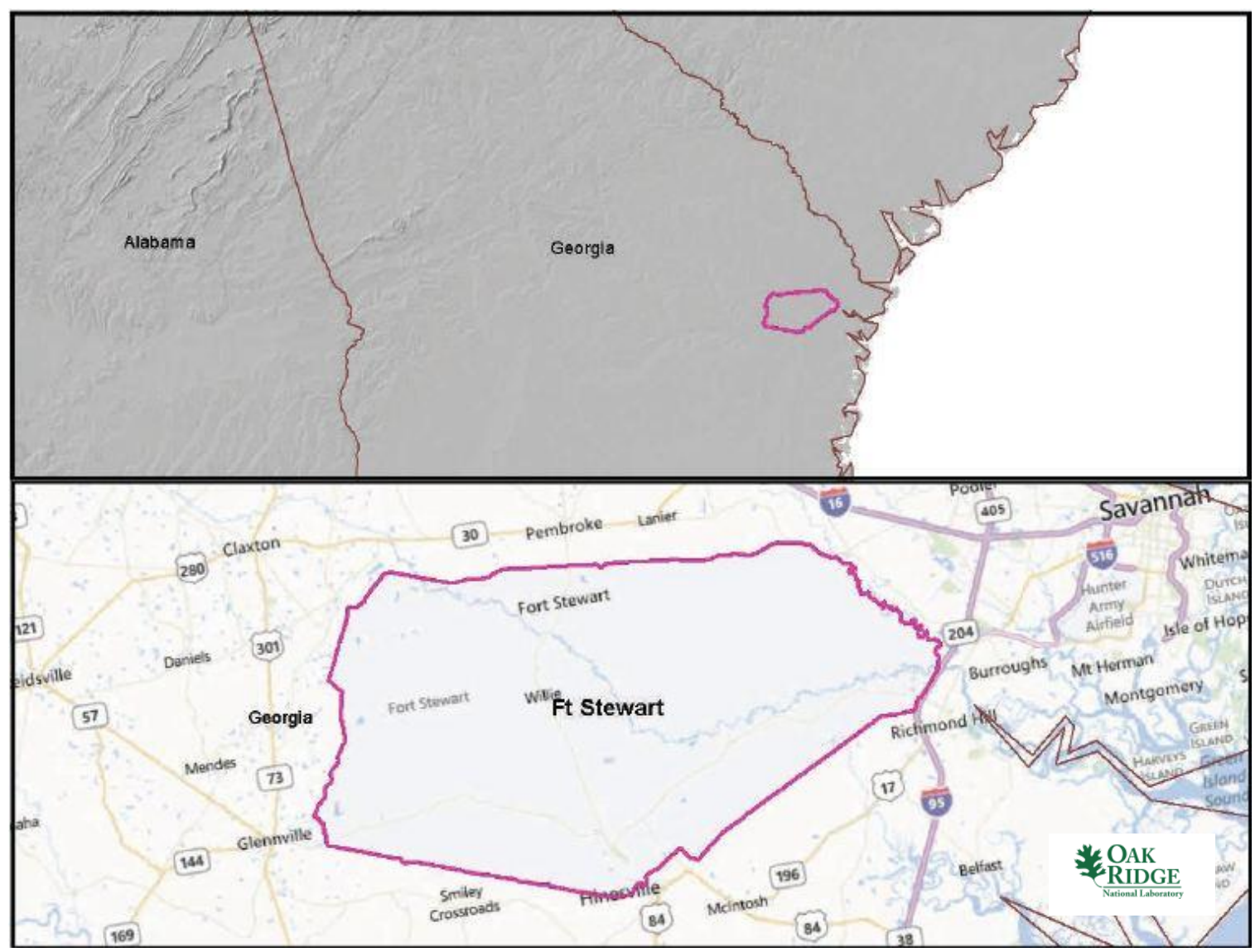

Fig. A.25. Fort Stewart.

\section{A.9.2 Site Description and Status}

Fort Stewart is home to the Hunter Army Airfield Command Group, Kelly Hill Command Group, the 3rd Infantry Division, its heavy, armored forces, and many tenant groups and agencies. Fort Stewart and Hunter Army Airfield serve about 21,000 soldiers, 29,500 family members and about 3,500 civilians, a base population of around 11,000 and the area population is about $31,000 .{ }^{38,39}$ Descriptions of the installation, missions, and base history are readily available on the Internet. ${ }^{40,41}$

\footnotetext{
${ }^{38} \mathrm{http}: / /$ apps.militaryonesource.mil/pls/psgprod/f?p=132:CONTENT:1587354447961103::NO::P4_INST_ID:1195

${ }^{39}$ http://en.wikipedia.org/wiki/Fort_Stewart,_Georgia

${ }^{40} \mathrm{http}: / /$ apps.militaryonesource.mil/MOS/f?p=MI:CONTENT:0::::P4_INST_ID,P4_CONTENT_TITLE,P4_CONTENT_EKMT_ ID,P4_CONTENT_DIRECTORY,P4_TAB:1195,Installation\%20Overview,30.90.30.30.30.0.0.0.0

${ }^{41}$ http://www.stewart.army.mil/DMWR/default.asp
} 
Services and resources are available on the base for military staff, families, employees, and services contractors similar to a small town, including lodging and housing, schools, hospital, various shopping facilities, restaurants, library, cultural and recreational amenities, and many other goods and services.

As noted in Table A.17, the nearest major fault line based on USGS data is noted to be 900 miles west in Oklahoma. The maximum safe shutdown earthquake for the site is below $0.3 \mathrm{~g}$ peak ground acceleration. The maximum slope on the site is less than $13 \%$. Greater than 500,000 gpm of cooling water makeup is available from the Canoochee River, which roughly bisects the base from the northwest to the east.

Table A.17. Fort Stewart site statistics

\begin{tabular}{|l|l|l|l|}
\hline $\begin{array}{l}\text { Population } \\
\text { Population Within }\end{array}$ & \multicolumn{2}{l|}{$\begin{array}{l}\text { Utility } \\
\text { Distance to Grid Capacity }\end{array}$} \\
\hline 0.5 mi of Site Boundary & $\sim 102,500$ & $>400 \mathrm{MWe}$ & $\sim 3 \mathrm{mi}$ \\
\hline $1 \mathrm{mi}$ of Site Boundary & $\sim 119,000$ & $>800 \mathrm{MWe}$ & $\sim 21 \mathrm{mi}$ \\
\hline $5 \mathrm{mi}$ of Site Boundary & $\sim 277,000$ & $>1600 \mathrm{MWe}$ & $\sim 0.1 \mathrm{mi}$ \\
\hline 10 mi of Site Boundary & $\sim 495,000$ & $>3200 \mathrm{MWe}$ & $\sim 193 \mathrm{mi}$ \\
\hline Nearest City with Population & Distance to Cooling Water \\
\hline$>10,000$ & Hinesville, GA & $>50,000 \mathrm{gpm}$ & $\sim 0.1 \mathrm{mi}$ (CanoocheeRiver) \\
\hline$>50,000$ & North Charleston, SC & $>100,000 \mathrm{gpm}$ & $\sim 0.1 \mathrm{mi}$ (CanoocheeRiver) \\
\hline$>100,000$ & Savannah, GA & $>200,000 \mathrm{gpm}$ & $\sim 0.1 \mathrm{mi}$ (CanoocheeRiver) \\
\hline$>500,000$ & Jacksonville, FL & $>500,000$ gpm & $\sim 0.1 \mathrm{mi}$ (CanoocheeRiver) \\
\hline Geotechnical & & Accessibility & \\
\hline Max Earthquake Acceleration & $<0.3 \mathrm{~g}$ & Distance to Major Roadway & $\sim 0.1$ mi (Interstate 95) \\
\hline Max Slope & $\sim 13 \%$ & Distance to Water Transport & $\sim 7$ mi (Pacific Deep) \\
\hline Nearest Fault Line & $\sim 915$ mi (Oklahoma) & Distance to Rail Transport & $\sim 0.1$ mi (USG) \\
\hline Nearest Hazard Site & $\sim 10$ mi (Savannah Int'l) & Distance to Airport & $\sim 10$ mi (Savannah Int'l) \\
\hline
\end{tabular}

\section{A.9.3 Aerial Imagery}

The aerial imagery in Fig. A.26 indicates the areas of population density in the south-central area of the base, the adjacent Mid Coast Regional Airport, and numerous roads and highways. The Canoochee River crosses the base from the northwest corner to the center of the base and then to the east to join the Ogeechee River to the nearby Atlantic Ocean. Numerous base facilities, buildings, ranges, airfield, and training areas are located on this large site. 


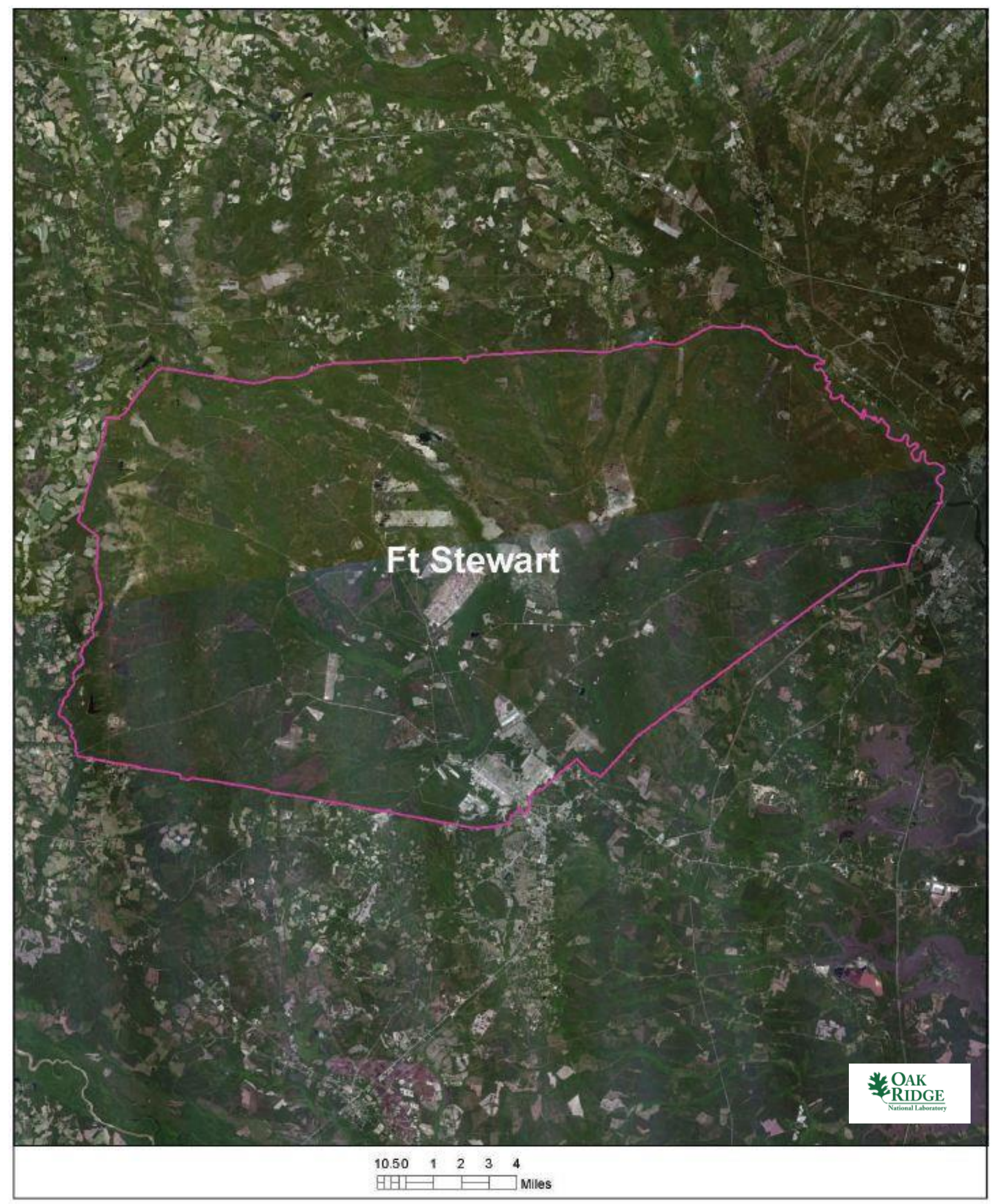

Fig. A.26. Satellite view of Fort Stewart area. 


\section{A.9.4 Screening Criteria Overview}

Table A.18 shows a screening criteria summary bar, or "dashboard" chart, for the site area provides a quick look at what siting issues may exist for the site. The criteria that are not met within the site area indicated.

Table A.18. Fort Stewart siting criteria summary

\section{Screening Criteria Summary Bar}

(Colored Boxes indicate Screening Results)

\begin{tabular}{|c|c|c|c|c|c|c|c|c|c|}
\hline \multicolumn{3}{|c|}{ No Siting Issue } & & & \multicolumn{2}{|c|}{ Partial Siting Issue } & & \multicolumn{2}{|c|}{ Full Siting Issue } \\
\hline $\begin{array}{l}\text { Inside } \\
\text { Military } \\
\text { Base }\end{array}$ & Poptiation & Slope & SSE & $\begin{array}{l}\text { Stream } \\
\text { llow } \\
(65,000 \\
\text { gpm) }\end{array}$ & $\begin{array}{l}\text { Proximity } \\
\text { to } \\
\text { Hazard } \\
\text { Operations }\end{array}$ & $\begin{array}{l}\text { Proximity } \\
\text { to } \\
\text { Fault } \\
\text { Lines }\end{array}$ & $\begin{array}{l}\text { Wetlands } \\
\text { Open } \\
\text { Water }\end{array}$ & \begin{tabular}{l|l|} 
100-year & Protected \\
Flood- & Lands \\
plain &
\end{tabular} & $\begin{array}{l}\text { Landslide } \\
\text { Hazards }\end{array}$ \\
\hline
\end{tabular}

\begin{tabular}{|l|c|}
\hline \multicolumn{2}{|c|}{ Screening Criteria Table } \\
\hline \multicolumn{1}{|c|}{ Criteria } & Value \\
\hline Population Density within 10 miles (people/square mile) & $>500$ \\
\hline Slope & $>18 \%$ \\
\hline Safe shutdown earthquake (ground acceleration) & $>0.5$ \\
\hline Streamflow/cooling water make-up (gpm) & $<65,000$ \\
\hline Proximity to hazardous operations - buffer (mile) & Depends on hazardous operation ${ }^{1}$ \\
\hline Proximity to fault lines - buffer (mile) & Depends on length of fault \\
\hline Wetlands/Open Water & - \\
\hline 100 -year floodplain & - \\
\hline Protected lands & - \\
\hline Landslide hazard (moderate and high) & - \\
\hline
\end{tabular}

${ }^{1}$ Hazardous facilities (airports- 5 miles and oil refineries- -1 mile) 


\section{A.9.5 Composite Map and Individual Siting Issue Maps}

A composite map of SMR siting challenges to the Fort Stewart is shown in Fig. A.27. Following this map are maps of the individual SMR siting criteria based on selected input values.

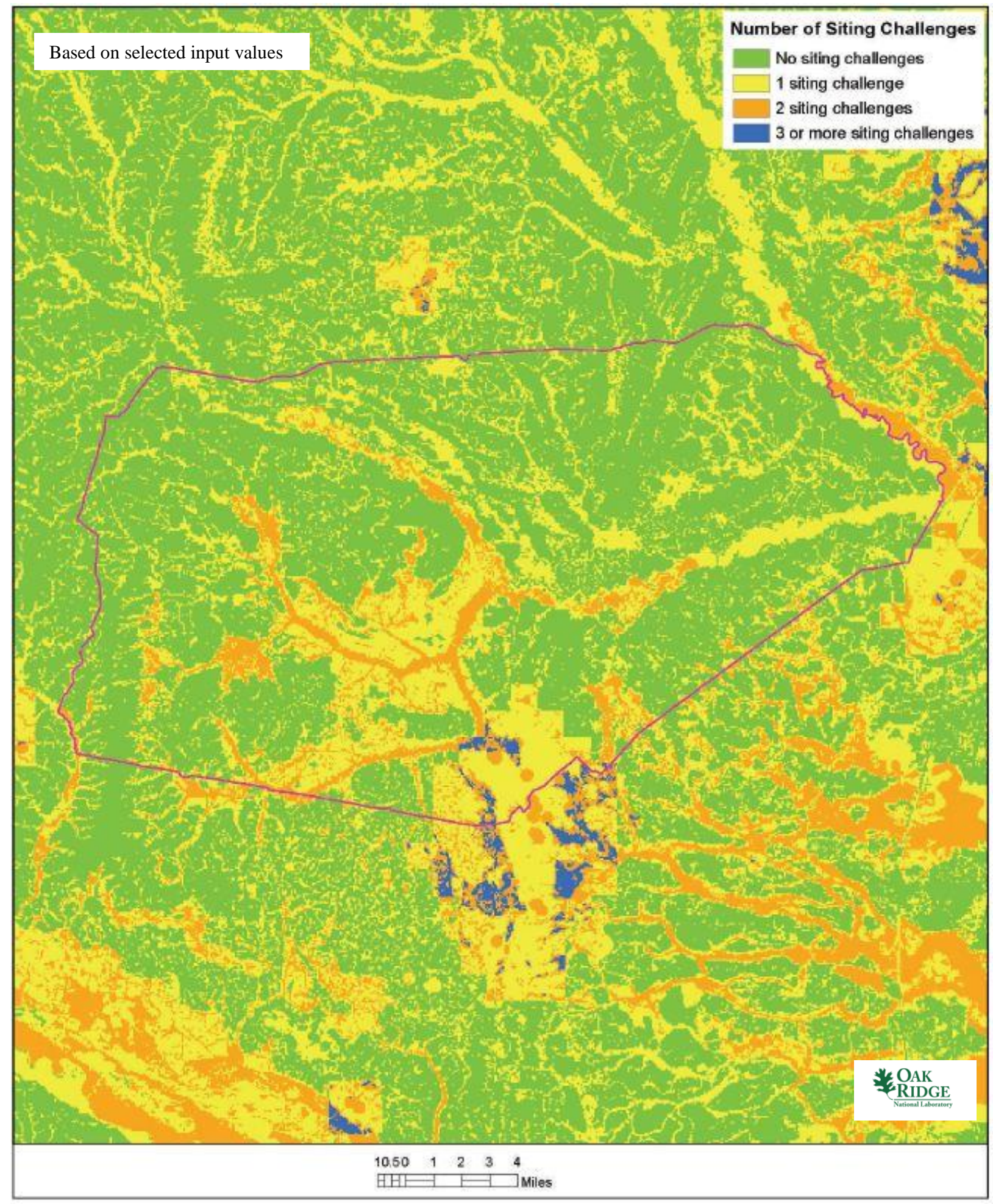

Fig. A.27. Fort Stewart composite map. 

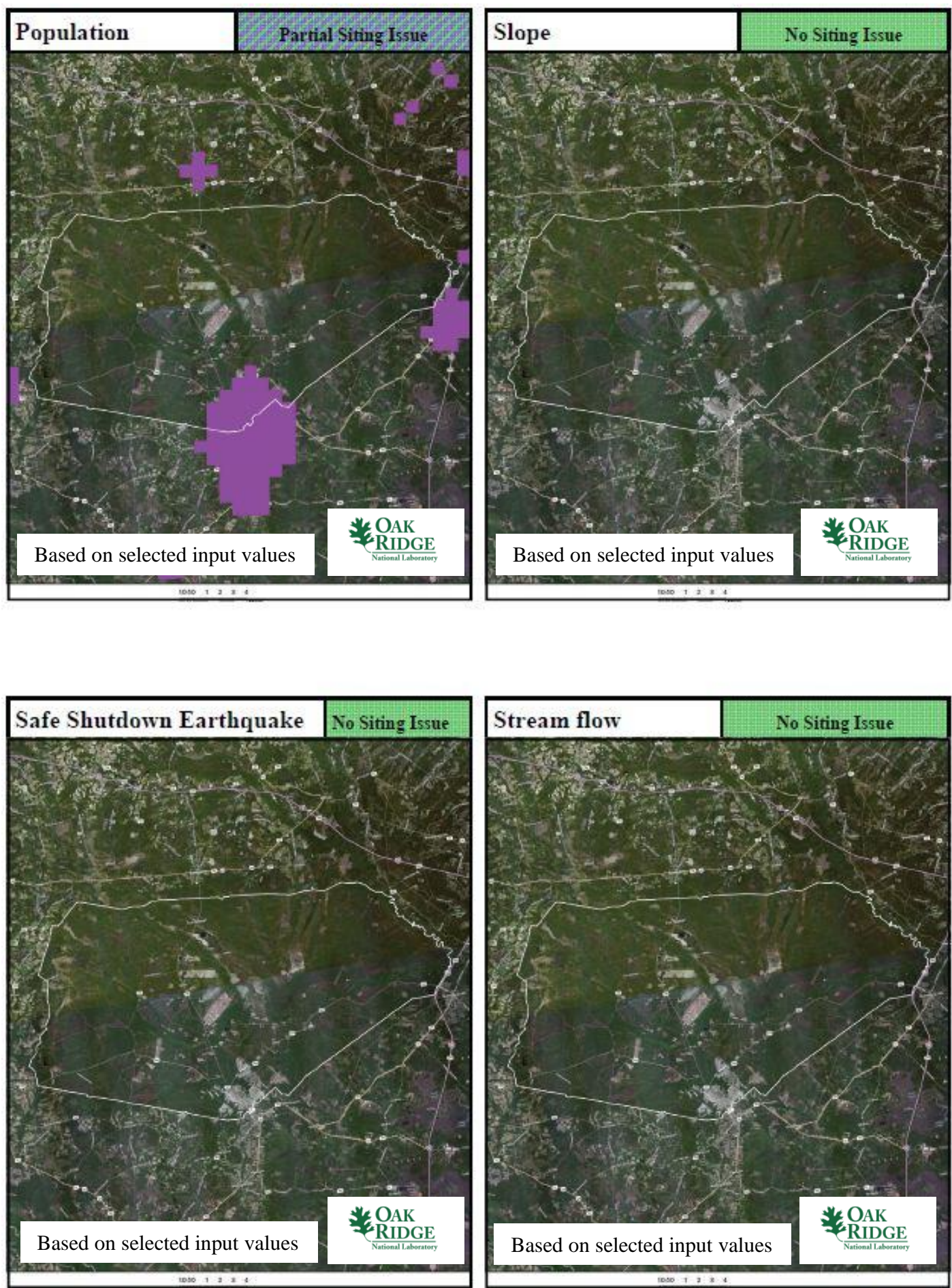

Fort Stewart 

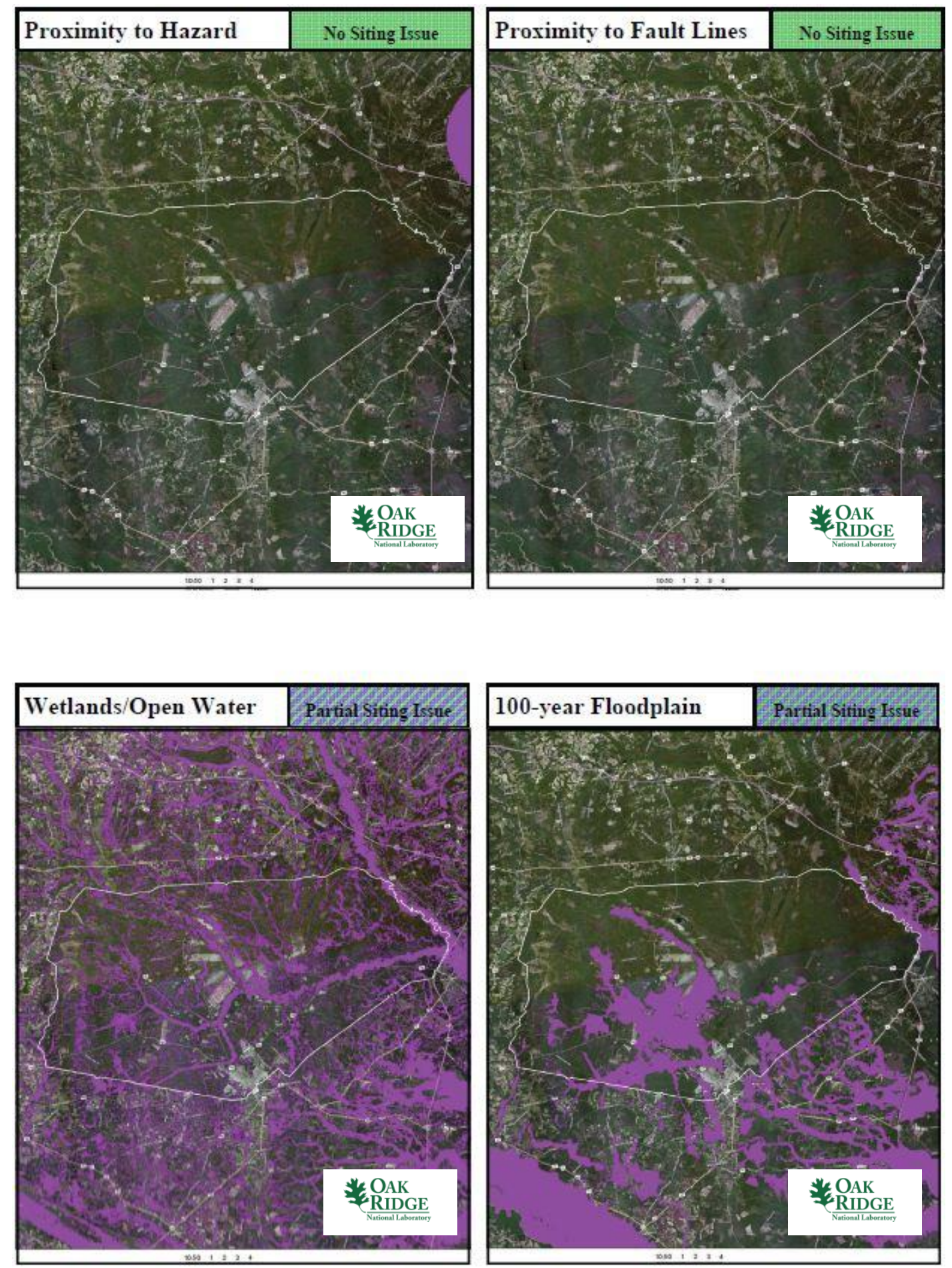

Fort Stewart 

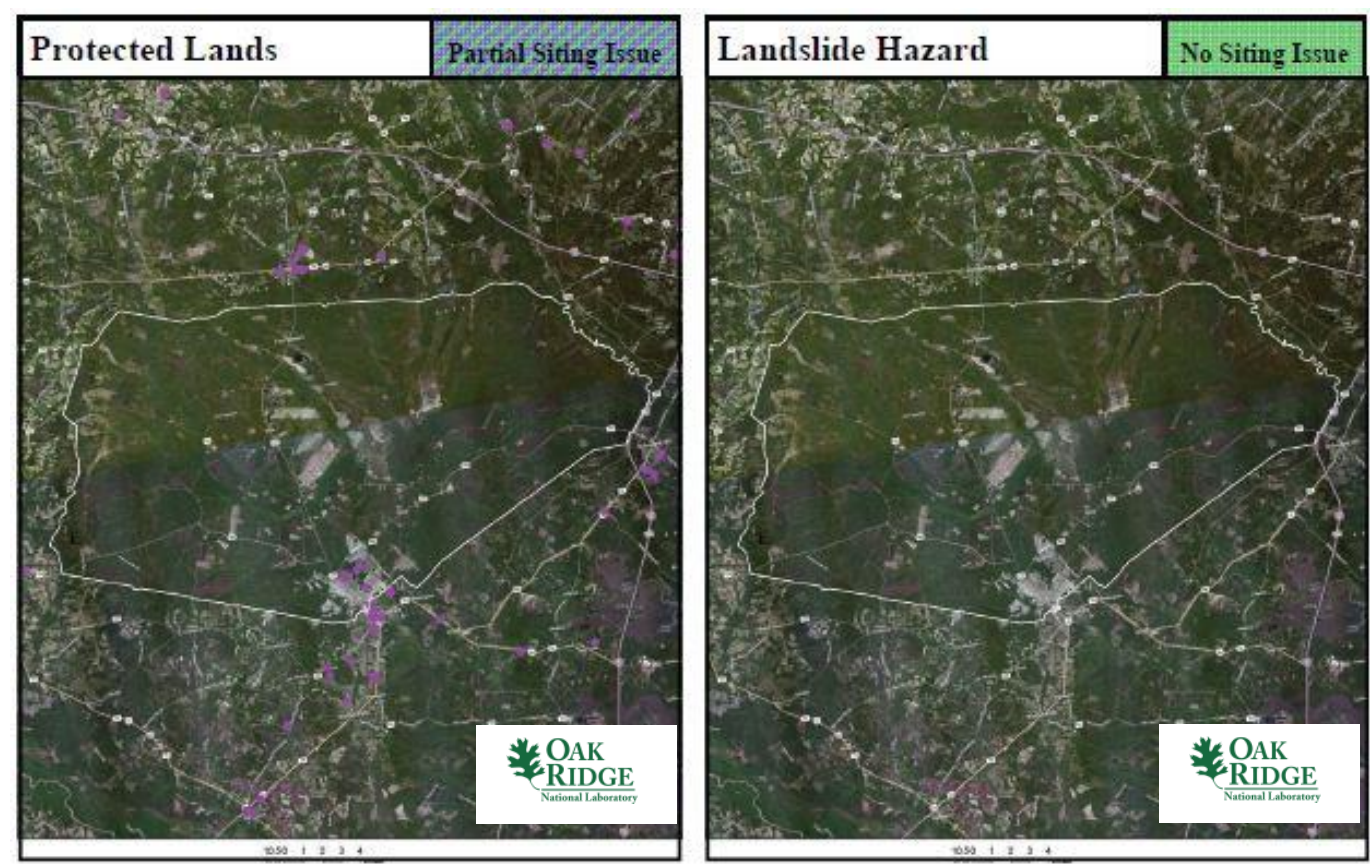

Fort Stewart

\section{A.9.6 Site Evaluation}

Fort Stewart is a large, federally controlled site. A well-trained, well-armed security force is available. Many of the activities and missions carried out on this base are high technology, mechanized endeavors. Personnel living or working on the base would have considerable familiarity with the technology- and security-related operations associated with nuclear power plant operation. Power demands on the base associated with the military missions and local infrastructure for current residents and workers would also be considerable and feasible for a site-located SMR.

As shown in Sects. A.9.4 and A.9.5, the Fort Stewart site has partial site issues with wetlands/open water and the 100-year flood plain. ${ }^{1}$ These concerns affect areas across the site. Approximately $62 \%$ of the 253,000-acre site meets multiple conventional standards for consideration of siting an SMR on the base facility. However, the clearly visible airfield in the satellite imagery was not automatically removed from consideration due to the special circumstances of this OR-SAGE application. The area around a commercial airport is typically buffered from siting consideration by OR-SAGE to a distance of 5 miles. Military airfields are not considered separately, because military facilities are already an SMR SSEC exclusion factor for commercial SMR siting. As a result, the airfield area on the base must be considered separately. Excluding land from consideration to a 5-mile radius from the center of the airfield essentially reduces the area suitable for siting an SMR to approximately 50\% of Fort Stewart. Note, however, that the composite map does not reflect specific hazards associated with the site, such as ordnance storage areas, weapons ranges, etc., that could render some areas of significant size as unsuitable for siting a reactor.

The site meets current NRC RG 4.7 recommendations for population density without additional consideration for relaxed SMR population siting requirements based on reduced source term. This site should be classified as favorable for siting an SMR. 


\section{A.10 NAVAL SURFACE WARFARE CENTER - CRANE}

\section{A.10.1 Location Detail}

As shown in Fig. A.28, the Naval Surface Warfare Center-Crane Division (NSWC-Crane) is located on about 55,000 acres ${ }^{6}$ (about 85 square miles) in south-central Indiana, near the town of Crane. NSWC-Crane provides a number of military development and support operations, including expeditionary warfare systems, fleet maintenance and modernization, radar, power systems, strategic systems, small arms, surface and airborne electronic warfare, night vision systems, undersea warfare systems, and systems development for the $\mathrm{DD}(\mathrm{X})$ destroyer and the littoral combat ship. ${ }^{42}$ Interstate 69 is approximately 5 miles from the northwest corner of the site. Highway 231 is on the western edge of the site. Numerous roads provide access to various site facilities and areas.

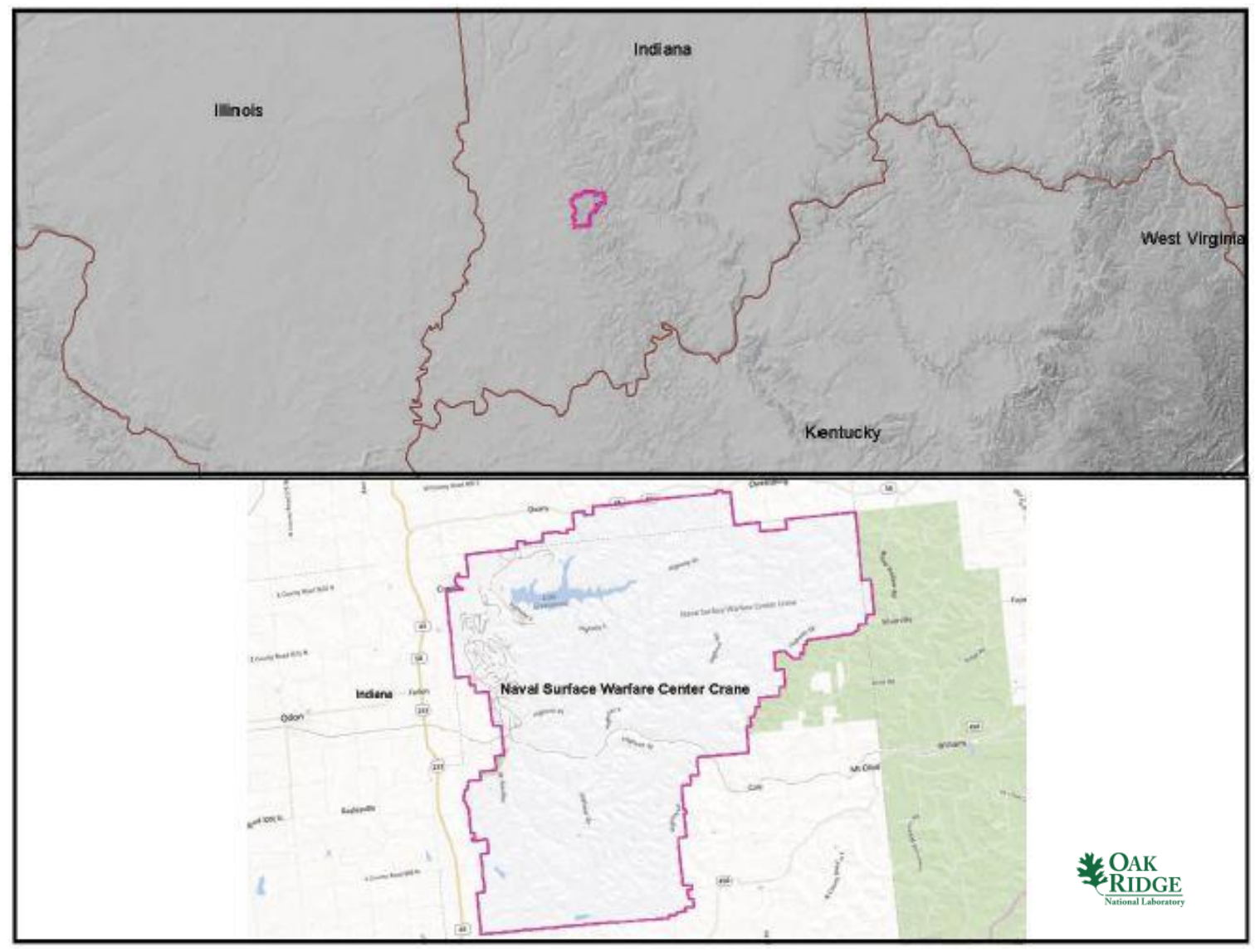

Fig. A.28. NSWC-Crane.

\section{A.10.2 Site Description and Status}

The NWSC-Crane supports a number of military activities associated with electronic warfare/information operations, special missions, and strategic missions, particularly associated with high technology. Major facilities at Crane include the strategic weapons systems engineering and evaluation complex, electronic warfare systems engineering complex, special operations weapons engineering and test facility, environmental and nondestructive test complex, pyrotechnic technology complex, and more. ${ }^{43}$

\footnotetext{
${ }^{42} \mathrm{http}: / /$ en.wikipedia.org/wiki/Naval_Surface_Warfare_Center_Crane_Division

${ }^{43} \mathrm{http}: / /$ www.navsea.navy.mil/nswc/Shared\%20Documents/crane.pdf
} 
Approximately 5,000 soldiers, employees, contractors, and families are on-site at any given time. ${ }^{44}$ Descriptions of the installation, missions, and base history are readily available on the Internet. ${ }^{45}$

As noted in Table A.19, the nearest major fault line based on USGS data is noted to be 650 miles southwest in Oklahoma. The maximum safe shutdown earthquake for the site is below $0.3 \mathrm{~g}$ peak ground acceleration. The maximum slope on the site is about $22 \%$. Greater than 500,000 gpm of cooling water makeup is available from the White River just southeast of the site. Major highways, water transport, and rail transport are nearby.

Table A.19. NSWC-Crane site statistics

\begin{tabular}{|l|l|l|l|}
\hline $\begin{array}{l}\text { Population } \\
\text { Population Within }\end{array}$ & \multicolumn{2}{l|}{$\begin{array}{l}\text { Utility } \\
\text { Distance to Grid Capacity }\end{array}$} \\
\hline $0.5 \mathrm{mi}$ of Site Boundary & $\sim 9,700$ & $>400 \mathrm{MWe}$ & $\sim 0.1 \mathrm{mi}$ \\
\hline $1 \mathrm{mi}$ of Site Boundary & $\sim 12,000$ & $>800 \mathrm{MWe}$ & $\sim 19 \mathrm{mi}$ \\
\hline $5 \mathrm{mi}$ of Site Boundary & $\sim 44,000$ & $>1600 \mathrm{MWe}$ & $\sim 22 \mathrm{mi}$ \\
\hline 10 mi of Site Boundary & $\sim 140,000$ & $>3200 \mathrm{MWe}$ & $\sim 160 \mathrm{mi}$ \\
\hline Nearest City with Population & Distance to Cooling Water \\
\hline$>10,000$ & Bedford, IN & $>50,000 \mathrm{gpm}$ & $\sim 1.0 \mathrm{mi}$ (White River) \\
\hline$>50,000$ & Bloomington, IN & $>100,000 \mathrm{gpm}$ & $\sim 1.0 \mathrm{mi}$ (White River) \\
\hline$>100,000$ & Evansville, IN & $>200,000$ gpm & $\sim 1.0 \mathrm{mi}$ (White River) \\
\hline$>500,000$ & Indianapolis, IN & $>500,000$ gpm & $\sim 1.0 \mathrm{mi}$ (White River) \\
\hline Geotechnical & & Accessibility & \\
\hline Max Earthquake Acceleration & $<0.3 \mathrm{~g}$ & Distance to Major Roadway & $\sim 34$ mi (Interstate 64 ) \\
\hline Max Slope & $\sim 22 \%$ & Distance to Water Transport & $\sim 42$ mi (Pacific Deep) \\
\hline Nearest Fault Line & $\sim 650$ mi (Oklahoma) & Distance to Rail Transport & $\sim 0.1$ mi (USG) \\
\hline Nearest Hazard Site & $\sim 42$ mi Refinery- \\
\hline
\end{tabular}

\section{A.10.3 Aerial Imagery}

The aerial imagery in Fig. A.29 indicates the greatest areas of buildings and roads to be in the northwest area of the site. Numerous facilities, buildings, and special purpose areas are located on this site.

\footnotetext{
${ }^{44} \mathrm{http}: / /$ www.in.gov/idem/4225.htm

${ }^{45} \mathrm{http}: / /$ www.navsea.navy.mil/nswc/Centers/Crane.aspx
} 


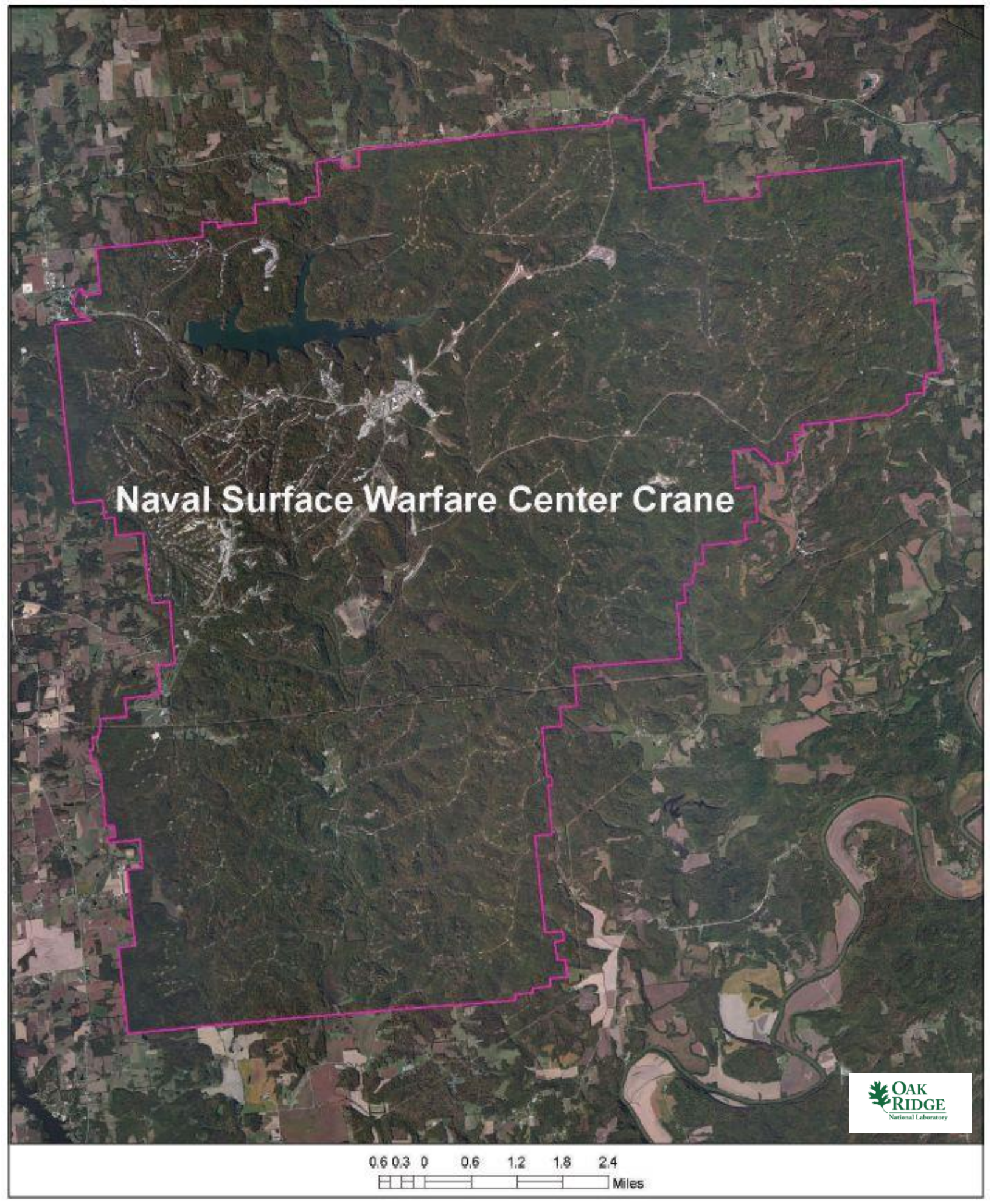

Fig. A.29. Satellite view of NSWC-Crane area. 


\section{A.10.4 Screening Criteria Overview}

Table A.20 shows a screening criteria summary bar, or "dashboard" chart, for the site area provides a quick look at what siting issues may exist for the site. The criteria that are not met within the site area indicated.

Table A.20. NSWC Siting criteria summary

\section{Screening Criteria Summary Bar}

(Colored Boxes indicate Screening Results)

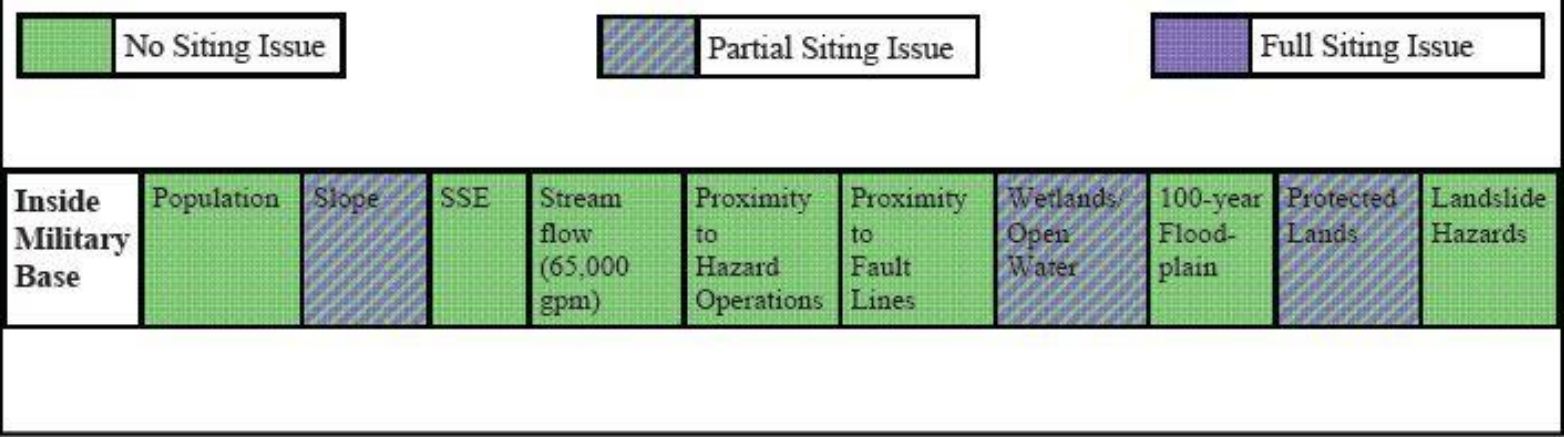

\begin{tabular}{|l|c|}
\hline \multicolumn{2}{|c|}{ Screening Criteria Table } \\
\hline \multicolumn{1}{|c|}{ Criteria } & Value \\
\hline Population Density within 10 miles (people/square mile) & $>500$ \\
\hline Slope & $>18 \%$ \\
\hline Safe shutdown earthquake (ground acceleration) & $>0.5$ \\
\hline Streamflow/cooling water make-up (gpm) & $<65,000$ \\
\hline Proximity to hazardous operations - buffer (mile) & Depends on hazardous operation ${ }^{1}$ \\
\hline Proximity to fault lines - buffer (mile) & Depends on length of fault \\
\hline Wetlands/Open Water & - \\
\hline 100 -year floodplain & - \\
\hline Protected lands & - \\
\hline Landslide hazard (moderate and high) & - \\
\hline
\end{tabular}

${ }^{1}$ Hazardous facilities (airports- 5 miles and oil refineries- -1 mile) 


\section{A.10.5 Composite Map and Individual Siting Issue Maps}

A composite map of SMR siting challenges to the NSWC is shown in Fig. A.30. There are few siting challenges on this site. Following this map are maps of the individual SMR siting criteria based on selected input values.

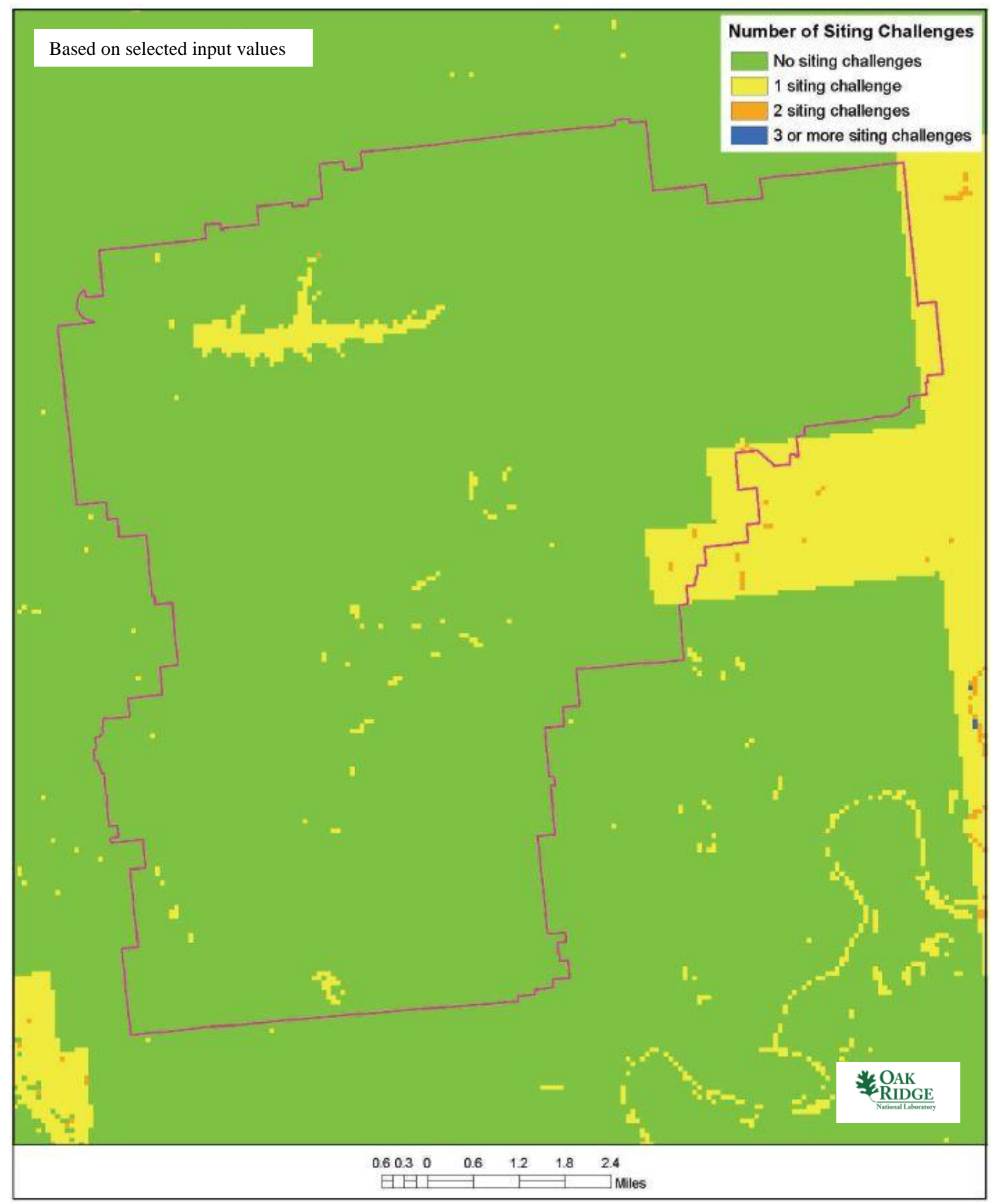

Fig. A.30. NSWC-Crane composite map. 

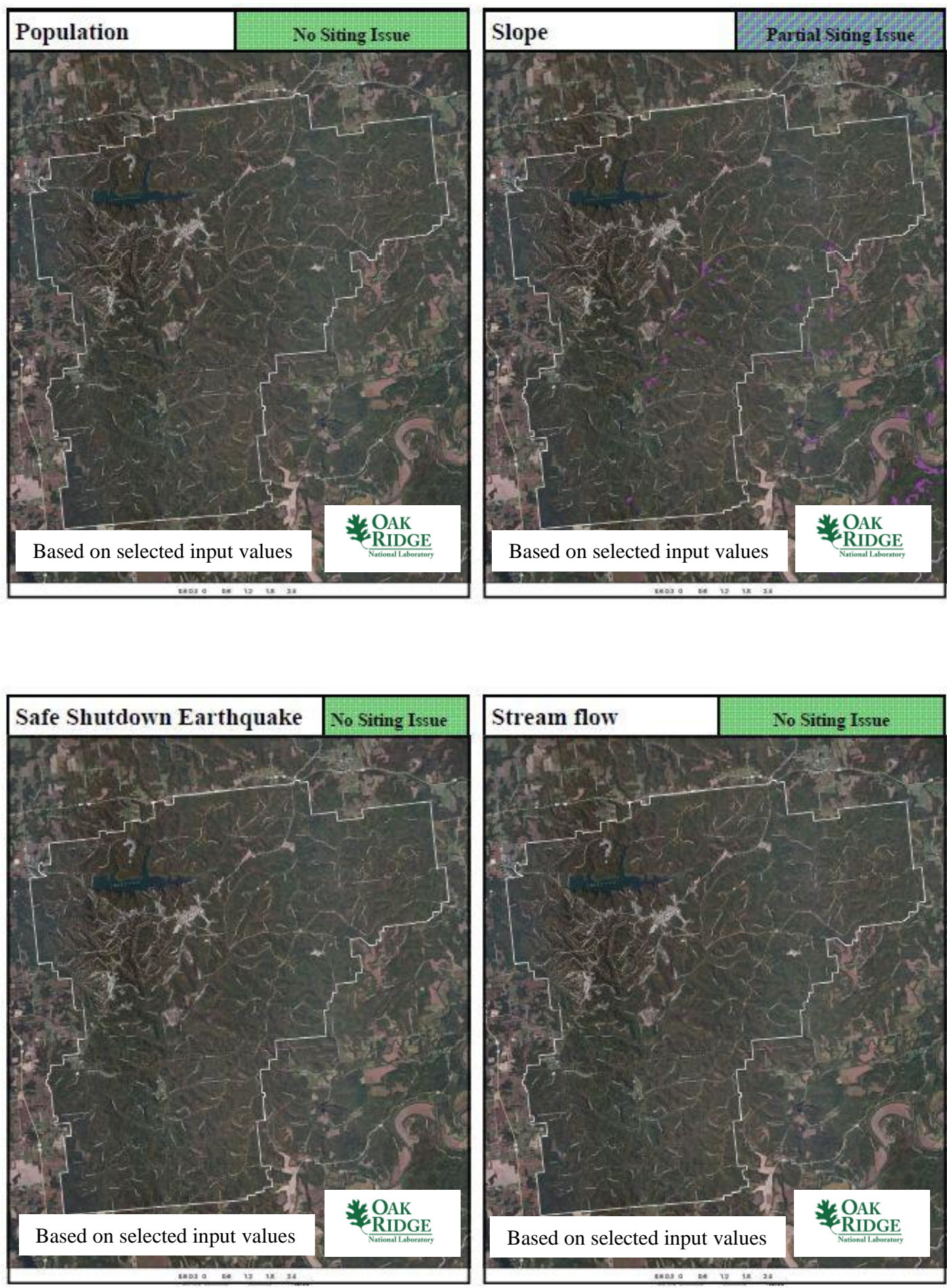

NSWC-Crane 

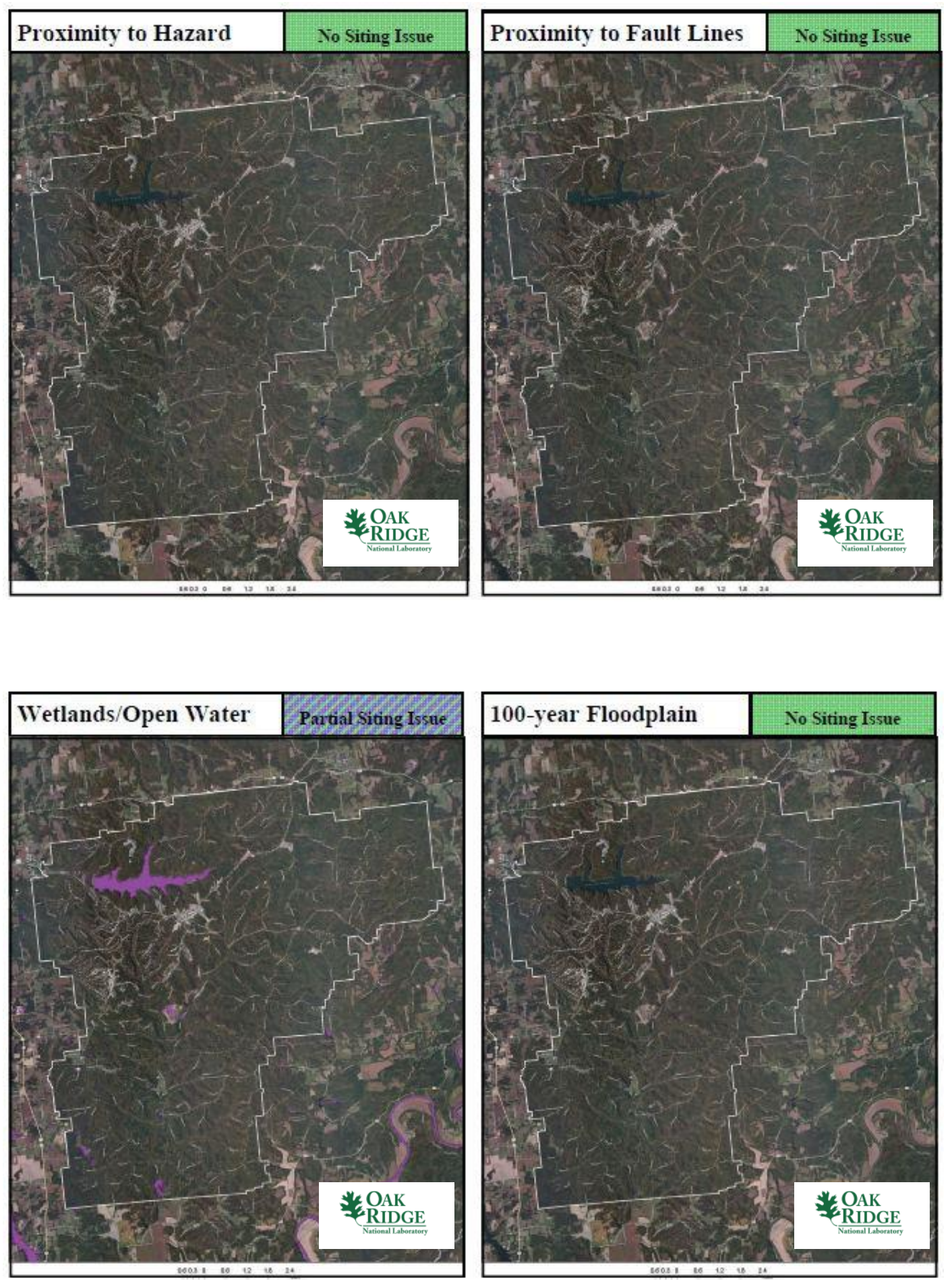

NSWC-Crane 

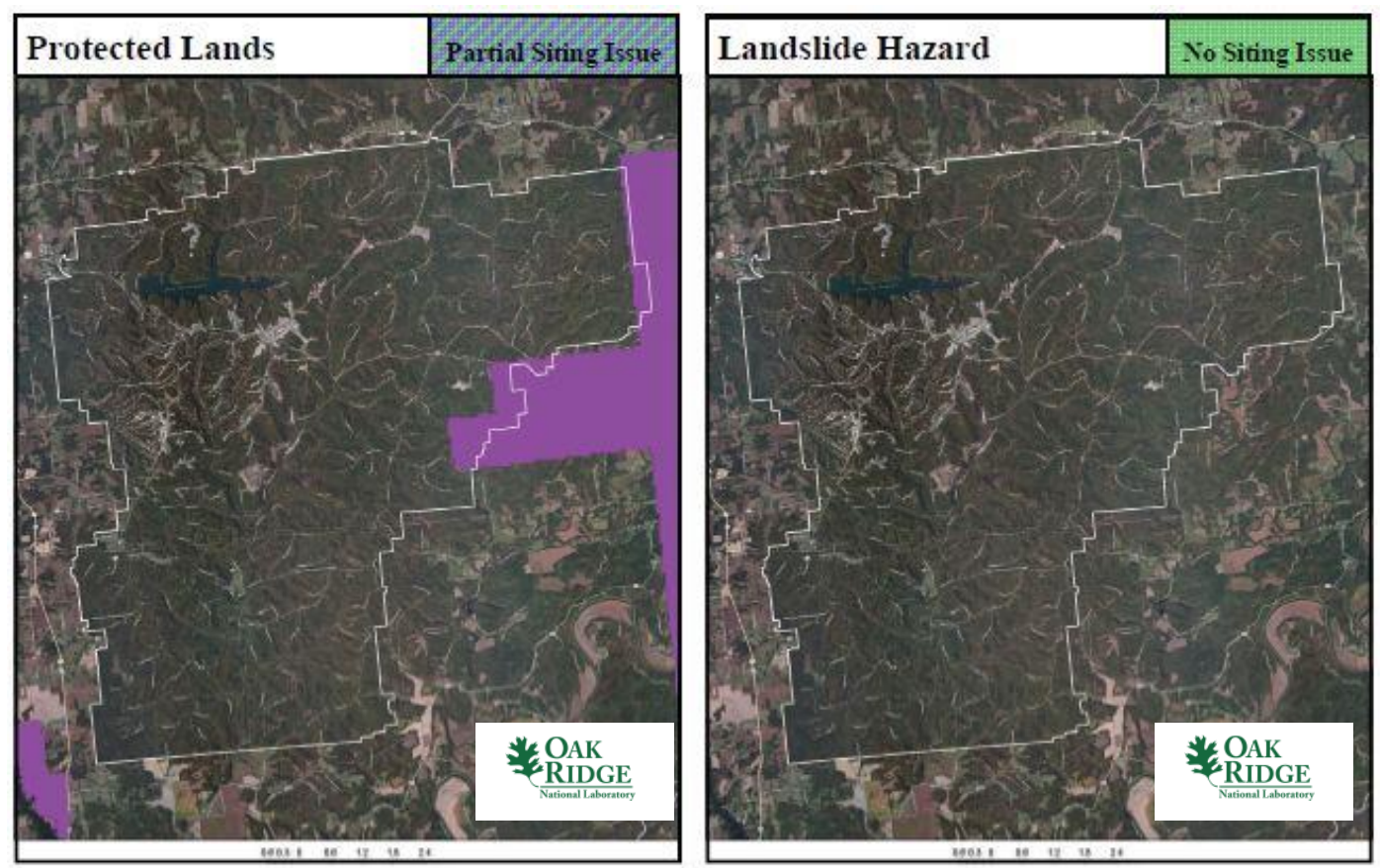

NSWC-Crane

\section{A.10.6 Site Evaluation}

Naval Surface Warfare Center-Crane is a large, federally controlled site. A well-trained, well-armed security force is available. Many of the activities and missions carried out on this base are high technology-related. Personnel working on the base would have considerable familiarity with the technology- and security-related operations associated with nuclear power plant operation. Power demands on the base associated with the military missions and local infrastructure would also be feasible for a site-located SMR.

As shown in Sects. A.10.4 and A.10.5, the NSWC-Crane site has limited partial site issues. ${ }^{1}$ These concerns primarily affect the periphery of the site. Approximately $95 \%$ of the 55,000-acre site meets multiple conventional standards for consideration of siting an SMR on the base facility. Note, however, that the composite map does not reflect specific hazards associated with the site, such as ordnance storage areas, weapons ranges, etc., that could render some areas of significant size as unsuitable for siting a reactor.

The site meets current NRC RG 4.7 recommendations for population density without additional consideration for relaxed SMR population siting requirements based on reduced source term. This site should be classified as favorable for siting an SMR. 


\section{APPENDIX B - DOE SITE EVALUATIONS}

\section{B.1 HANFORD SITE}

\section{B.1.1 Location Detail}

As shown in Fig. B.1, Hanford site is located on about 380,000 acres $^{6}$ (about 590 square miles) in the shrub-steppe desert of southeastern Washington State just northwest of the tri-cities of Richland, Pasco and Kennewick, Washington.

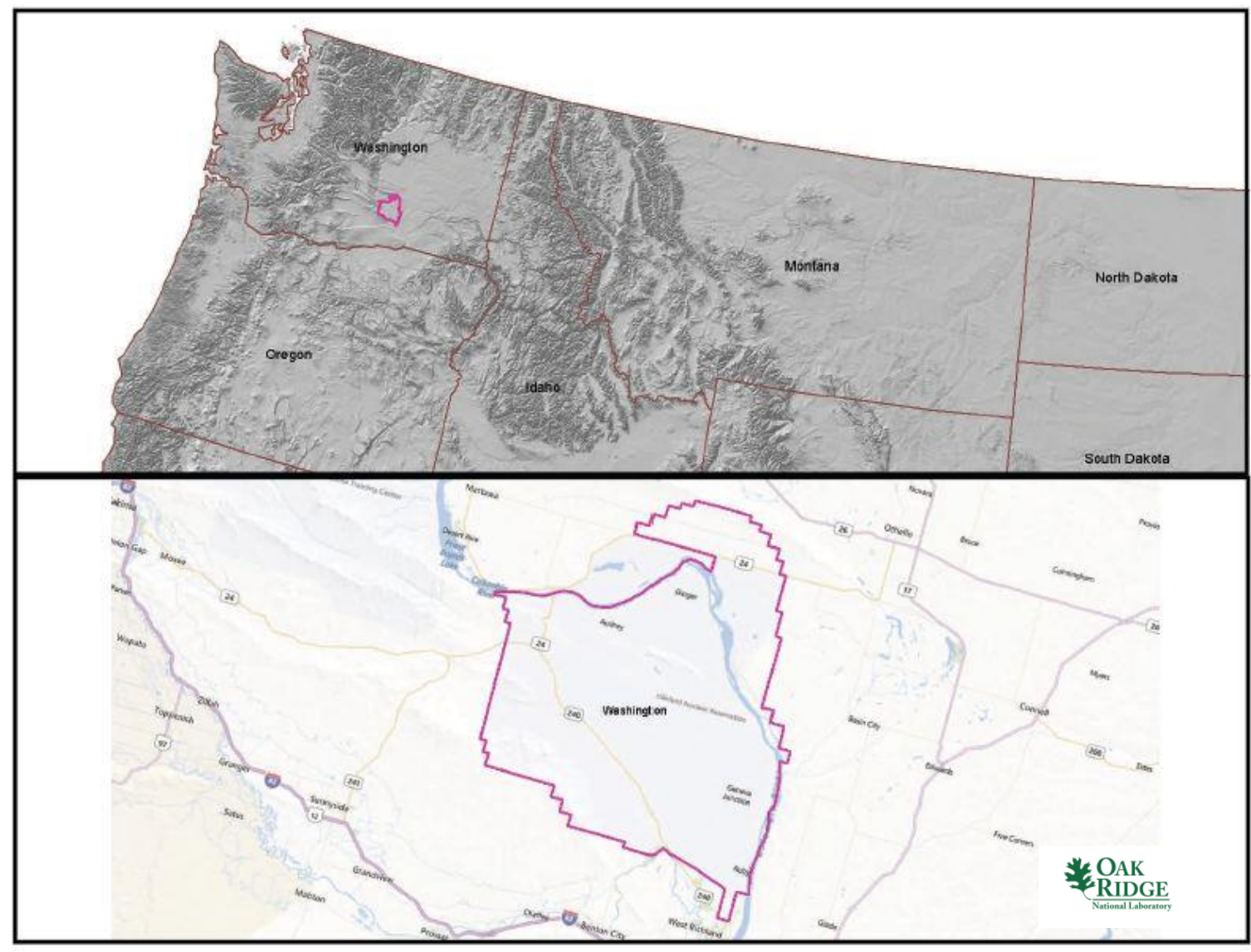

Fig. B.1. Hanford site.

\section{B.1.2 Site Description and Status}

The cities of Richland, Pasco, and Kennewick, Washington, are just southeast of the Hanford site. The Hanford site was a Manhattan Project site where nine nuclear reactors and numerous processing facilities were used to produce plutonium for use in nuclear weapons. ${ }^{46}$ The facilities were shut down following the Cold War. Longtime a home to nuclear-related activities, the site is managed by the DOE Richland Operations Office and the DOE Office of River Protection. The site is the object of intensive cleanup activities, hosts the Columbia Generating Station, and scientific research and development institutions with numerous government, industrial, and academic customers, including the DOE's Pacific Northwest

\footnotetext{
${ }^{46}$ http://www.pnl.gov/main/publications/external/technical_reports/pnnl-14687sum.pdf
} 
National Laboratory (PNNL) and the Laser Interferometer Gravitational Wave Observatory. Approximately 11,000 people work at the site, including about 5,000 at PNNL. ${ }^{47}$

As noted in Table B.1, the nearest major fault line based on USGS data is on-site. The maximum safe shutdown earthquake for the site is less than $0.3 \mathrm{~g}$ peak ground acceleration. The maximum slope on the site is about $74 \%$. Greater than 500,000 gpm of cooling water makeup is available from the Columbia River. Highway, rail, and water transport are nearby. Interstates 82 and 182 are south of the site. Highway 240 passes from southeast to northwest through the western third of the site.

Table B.1. Hanford site statistics

\begin{tabular}{|l|l|l|l|}
\hline $\begin{array}{l}\text { Population } \\
\text { Population Within }\end{array}$ & \multicolumn{2}{l|}{$\begin{array}{l}\text { Utility } \\
\text { Distance to Grid Capacity }\end{array}$} \\
\hline $0.5 \mathrm{mi}$ of Site Boundary & $\sim 40,000$ & $>400 \mathrm{MWe}$ & $\sim 0.1 \mathrm{mi}$ \\
\hline $1 \mathrm{mi}$ of Site Boundary & $\sim 40,000$ & $>800 \mathrm{MWe}$ & $\sim 26 \mathrm{mi}$ \\
\hline $5 \mathrm{mi}$ of Site Boundary & $\sim 40,000$ & $>1600 \mathrm{MWe}$ & $\sim 700 \mathrm{mi}$ \\
\hline 10 mi of Site Boundary & $\sim 40,000$ & $>3200 \mathrm{MWe}$ & $\sim 700 \mathrm{mi}$ \\
\hline Nearest City with Population & Distance to Cooling Water \\
\hline$>10,000$ & Richland, WA & $>50,000$ gpm & $\sim 0.1 \mathrm{mi}$ (Yakima River) \\
\hline$>50,000$ & Kennewick, WA & $>100,000$ gpm & $\sim 0.1 \mathrm{mi}$ (Yakima River) \\
\hline$>100,000$ & Spokane, WA & $>200,000$ gpm & $\sim 0.1 \mathrm{mi}$ (Yakima River) \\
\hline$>500,000$ & Seattle, WA & $>500,000$ gpm & $\sim 0.1 \mathrm{mi}$ (Yakima River) \\
\hline Geotechnical & & Accessibility & \\
\hline Max Earthquake Acceleration & $<0.3 \mathrm{~g}$ & Distance to Major Roadway & $\sim 0.1 \mathrm{mi}$ (SR 240) \\
\hline Max Slope & $\sim 74 \%$ & Distance to Water Transport & $\sim 0.1 \mathrm{mi}$ (Columbia River) \\
\hline Nearest Fault Line & On Site & Distance to Rail Transport & $\sim 0.1$ mi (USG) \\
\hline Nearest Hazard Site & $\sim 8$ mi (Airport-Tri-Cities) & Distance to Airport & $\sim 8$ mi (Tri-Cities) \\
\hline
\end{tabular}

\section{B.1.3 Aerial Imagery}

The aerial imagery in Fig. B.2 indicates the areas of population density primarily in the central and southern areas of the sites at the former production and processing facilities, PNNL, Columbia Generation Station, and the LIGO Hanford Observatory. The city of Richland is at the southeastern tip of the site. The cities of Pasco and Kennewick are about 10 miles southeast. The Columbia River is prominent in the northern and eastern areas of the site.

\footnotetext{
${ }^{47}$ www.pnnl.gov/about/
} 


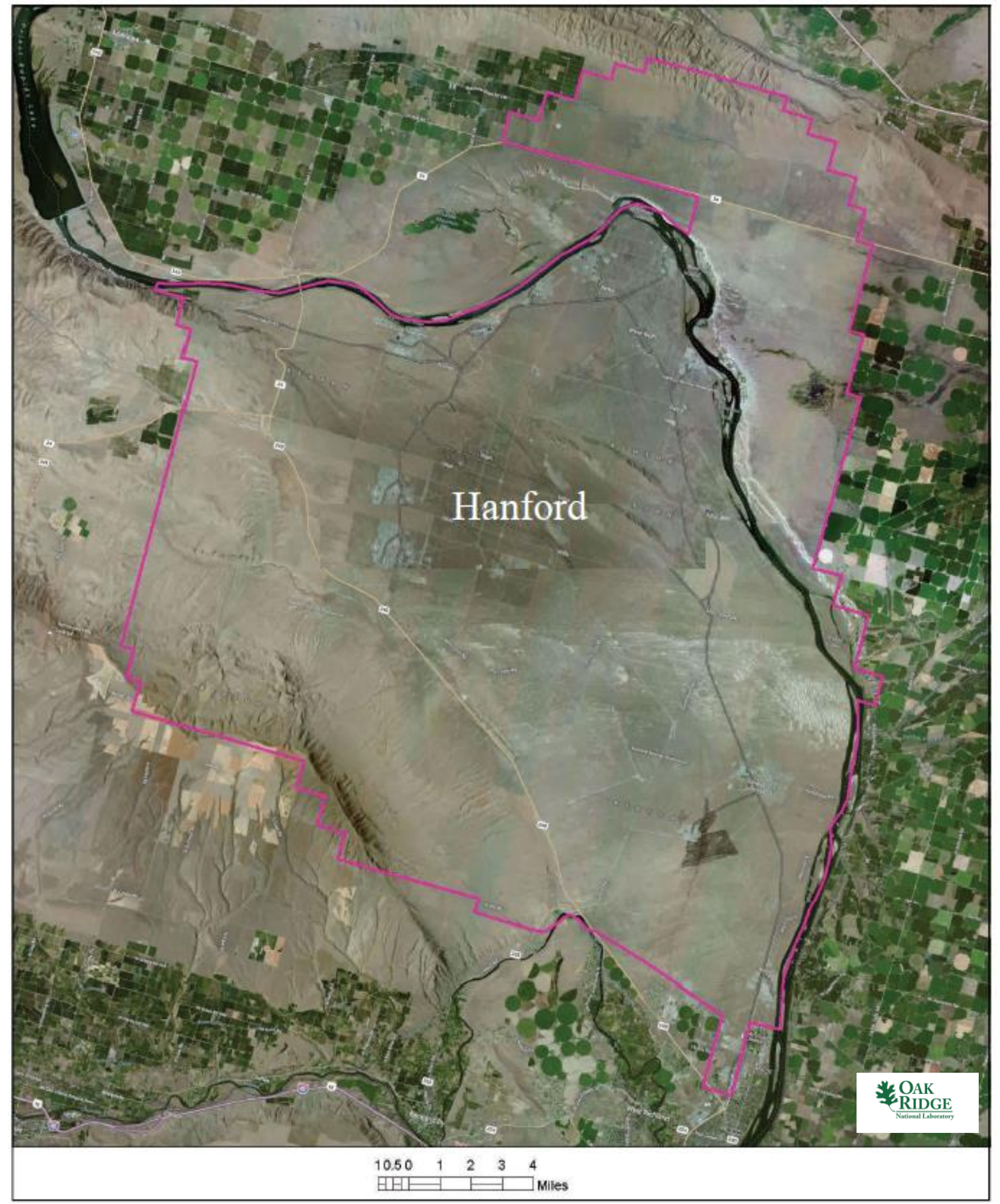

Fig. B.2. Satellite view of Hanford site area. 


\section{B.1.4 Screening Criteria Overview}

Table B.2 shows a screening criteria summary bar, or "dashboard" chart, for the site area provides a quick look at what siting issues may exist for the site. The criteria that are not met within the site area indicated.

Table B.2. Hanford site siting criteria summary

\section{Screening Criteria Summary Bar}

(Colored Boxes indicate Screening Results)

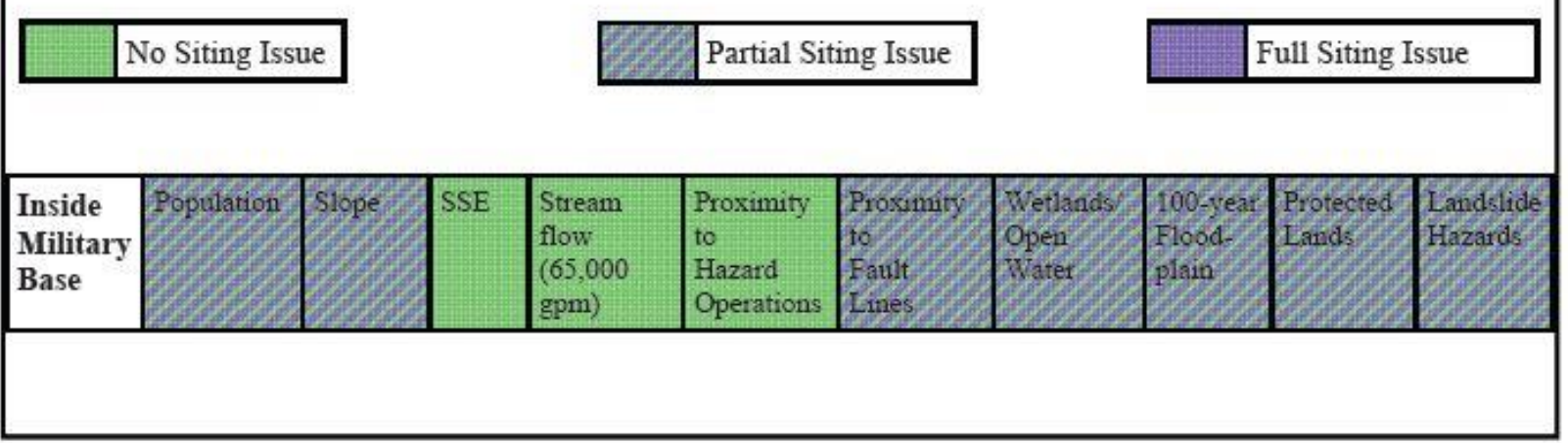

\begin{tabular}{|l|l|}
\hline \multicolumn{2}{|c|}{ Screening Criteria Table } \\
\hline \multicolumn{1}{|c|}{ Criteria } & Value \\
\hline Population Density within 10 miles (people/square mile) & $>500$ \\
\hline Slope & $>18 \%$ \\
\hline Safe shutdown earthquake (ground acceleration) & $>0.5$ \\
\hline Streamflow/cooling water make-up (gpm) & $<65,000$ \\
\hline Proximity to hazardous operations - buffer (mile) & Depends on hazardous operation ${ }^{1}$ \\
\hline Proximity to fault lines - buffer (mile) & Depends on length of fault \\
\hline Wetlands/Open Water & - \\
\hline 100-year floodplain & - \\
\hline Protected lands & - \\
\hline Landslide hazard (moderate and high) & - \\
\hline
\end{tabular}

${ }^{1}$ Hazardous facilities (airports-5 miles and oil refineries-1 mile) 


\section{B.1.5 Composite Map and Individual Siting Issue Maps}

A composite map of SMR siting challenges to the Hanford site is shown in Fig. B.3. Areas free of siting challenges are predominantly in the central southern area of the site. Following this map are maps of the individual SMR siting criteria based on selected input values.

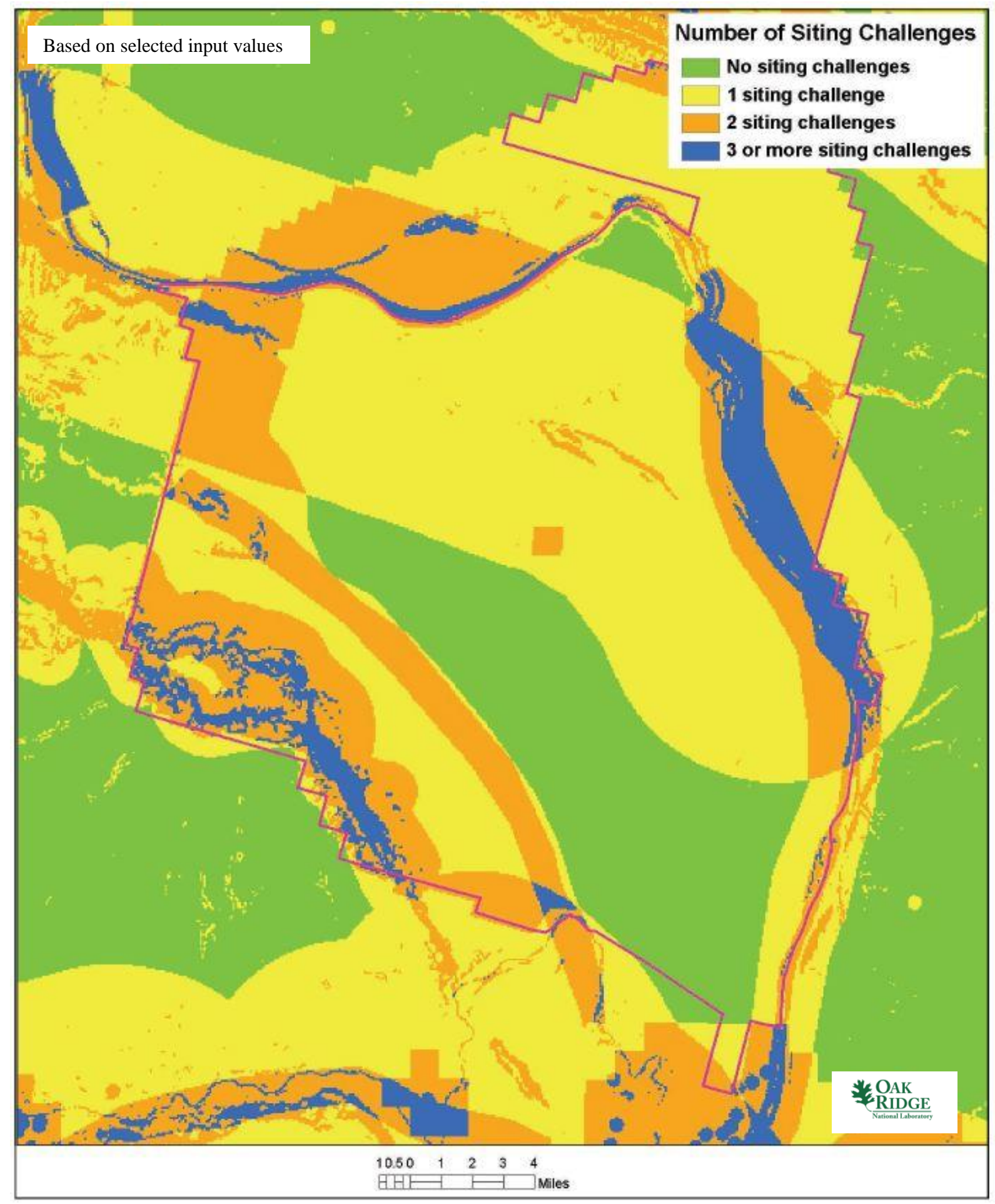

Fig. B.3. Hanford site composite map. 

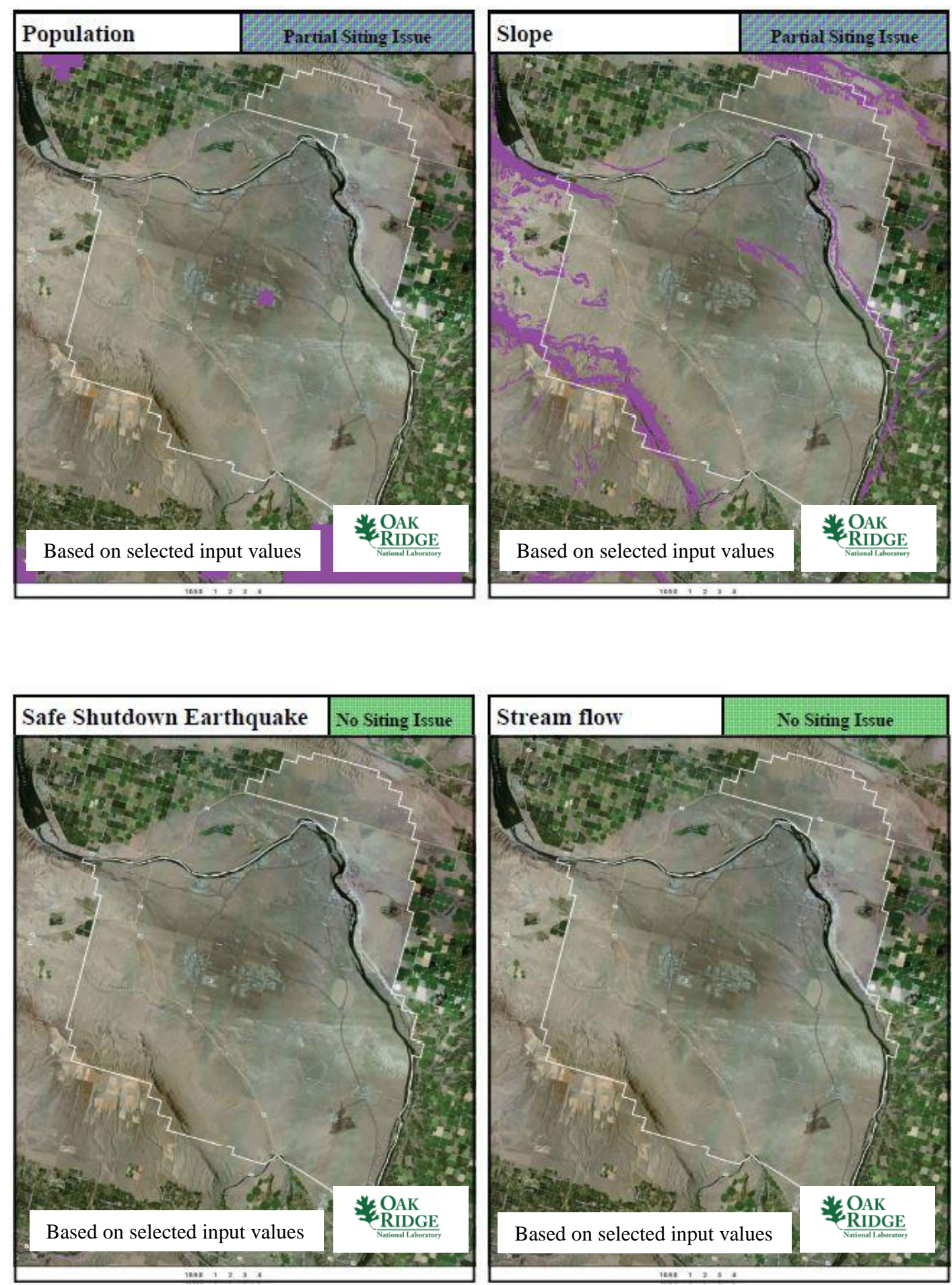

Hanford Site 

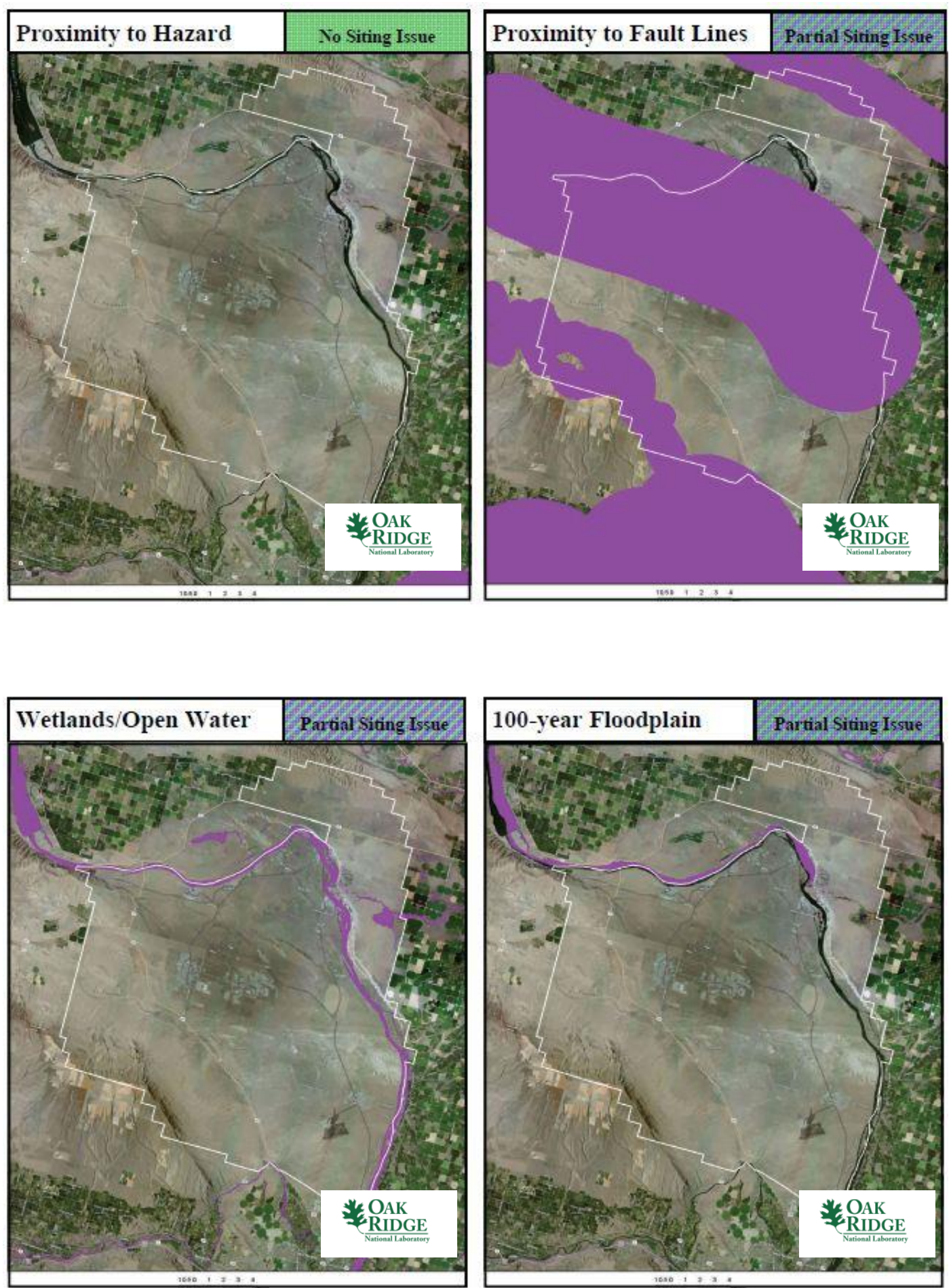

Hanford Site 

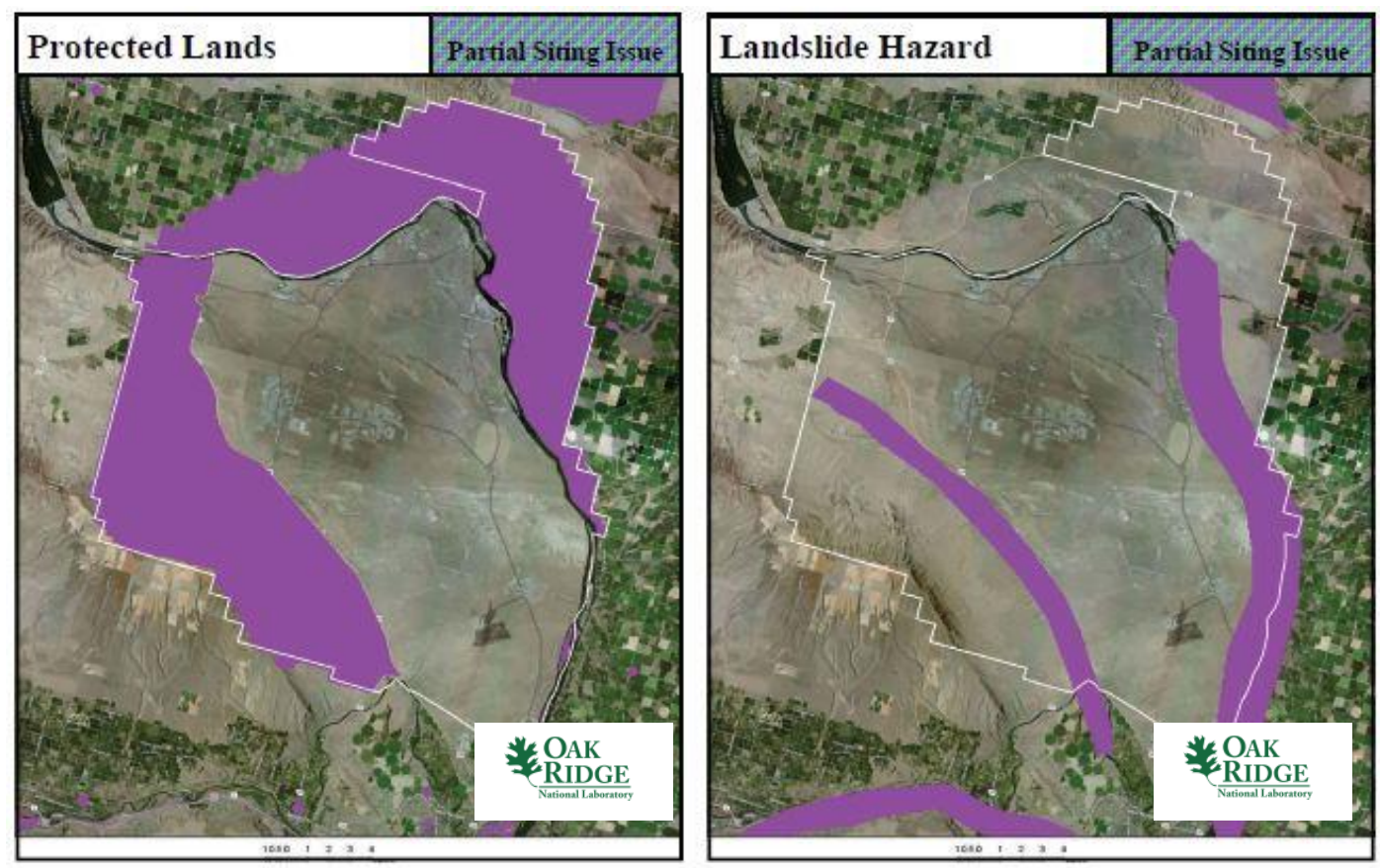

Hanford Site

\section{B.1.6 Site Evaluation}

Hanford site is a large, federally controlled site. A well-trained, well-armed security force is available. Many of the activities and missions carried out on this site are high technology, nuclear-related endeavors. Personnel working on the site would have considerable familiarity with the technology- and security-related operations associated with nuclear power plant operation. Power demands on the site associated with the scientific research centers would also be considerable. At one time, two additional large nuclear power stations were planned for the site of the Columbia Generation Station, but were cancelled. However, future load demand may be well-suited to an SMR.

As shown in Sects. B.1.4 and B.1.5, the Hanford site has multiple partial site issues. ${ }^{1}$ These concerns overlap to limit areas that meet all SMR SSEC to essentially one continuous portion of the site. Approximately $20 \%$ of the 380,000-acre site meets multiple conventional standards for consideration of siting an SMR on the DOE facility. Note, however, that the composite map does not reflect specific hazards associated with the site, such as former plutonium production or processing areas that could render some areas of significant size as unsuitable for siting a new reactor.

The site meets current NRC RG 4.7 recommendations for population density without additional consideration for relaxed SMR population siting requirements based on reduced source term. This site should be classified as favorable for siting an SMR. 


\section{B.2 IDAHO NATIONAL LABORATORY SITE}

\section{B.2.1 Location Detail}

As shown in Fig. B.4, Idaho National Laboratory (INL) site is a DOE site located on about 570,000 acres ${ }^{6}$ (about 890 square miles) in the high desert area approximately 30 miles east of Idaho Falls, Idaho.

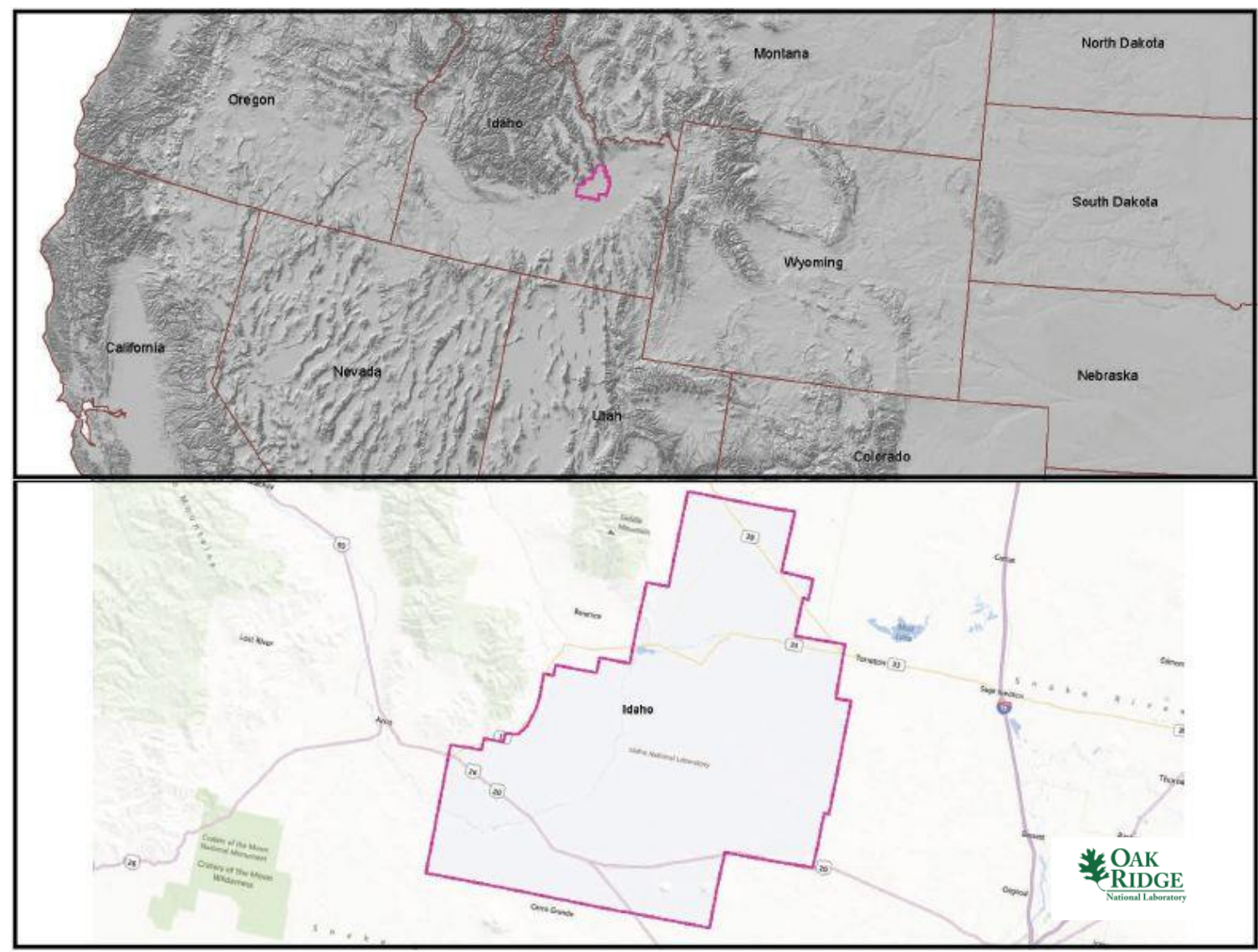

Fig. B.4. Idaho National Laboratory site.

\section{B.2.2 Site Description and Status}

The INL site is a science-based, applied engineering laboratory whose main missions are nuclear and energy research, science, and national defense. ${ }^{48}$ It is a site with a long history in the nuclear science and technology area. Fifty-two reactors have been built at the INL site. The INL Site is home to the numerous facilities of the INL, including the Advanced Test Reactor Complex and the Materials and Fuels Complex. The Research and Education Campus is located in the town of Idaho Falls. The INL employs approximately 4,000 people.

As noted in Table B.3, the nearest major fault line based on USGS data is noted to be 1,267 miles southwest in Kansas. The maximum safe shutdown earthquake for the site is below $0.3 \mathrm{~g}$ peak ground acceleration. The maximum slope on the site is about $75 \%$. Greater than 500,000 gpm of cooling water makeup is available from the Big Lost River. Major highways and rail transport are nearby. Water transport is about 250 miles away.

\footnotetext{
${ }^{48}$ https://inlportal.inl.gov/portal/server.pt/community/about_inl/259
} 
Table B.3. Idaho National Laboratory Site Statistics

\begin{tabular}{|l|l|l|l|}
\hline \multicolumn{2}{|l|}{$\begin{array}{l}\text { Population } \\
\text { Population Within }\end{array}$} & \multicolumn{2}{l|}{ Distance to Grid Capacity } \\
\hline $0.5 \mathrm{mi}$ of Site Boundary & $\sim 7,800$ & $>400 \mathrm{MWe}$ & $\sim 0.1 \mathrm{mi}$ \\
\hline 1 mi of Site Boundary & $\sim 7,800$ & $>800 \mathrm{MWe}$ & $\sim 52 \mathrm{mi}$ \\
\hline $5 \mathrm{mi}$ of Site Boundary & $\sim 7,800$ & $>1600 \mathrm{MWe}$ & $\sim 350 \mathrm{mi}$ \\
\hline $10 \mathrm{mi}$ of Site Boundary & $\sim 7,800$ & $>3200 \mathrm{MWe}$ & $\sim 350 \mathrm{mi}$ \\
\hline Nearest City with Population & Distance to Cooling Water \\
\hline$>10,000$ & Blackfoot, ID & $>50,000 \mathrm{gpm}$ & $\sim 0.1 \mathrm{mi}$ (Big Lost River) \\
\hline$>50,000$ & Idaho Falls, ID & $>100,000 \mathrm{gpm}$ & $\sim 0.1 \mathrm{mi}$ (Big Lost River) \\
\hline$>100,000$ & Boise, ID & $>200,000 \mathrm{gpm}$ & $\sim 0.1 \mathrm{mi}$ (Big Lost River) \\
\hline$>500,000$ & Denver, CO & $>500,000$ gpm & $\sim 0.1 \mathrm{mi}$ (Big Lost River) \\
\hline Geotechnical & & Accessibility & \\
\hline Max Earthquake Acceleration & $<0.3 \mathrm{~g}$ & Distance to Major Roadway & $\sim 0.1 \mathrm{mi}$ (SR 28) \\
\hline Max Slope & $\sim 75 \%$ & Distance to Water Transport & $\sim 246 \mathrm{mi}$ (Snake River) \\
\hline Nearest Fault Line & On Site & Distance to Rail Transport & $\sim 0.1 \mathrm{mi}$ (USG) \\
\hline Nearest Hazard Site & $\sim 19 \mathrm{mi}$ (Airport-Idaho & Distance to Airport & $\sim 19 \mathrm{mi}$ (Idaho Falls \\
\hline
\end{tabular}

\section{B.2.3 Aerial Imagery}

The aerial imagery in Fig. B.5 indicates the site facilities located in diverse locations mostly in the southern half of the site. 


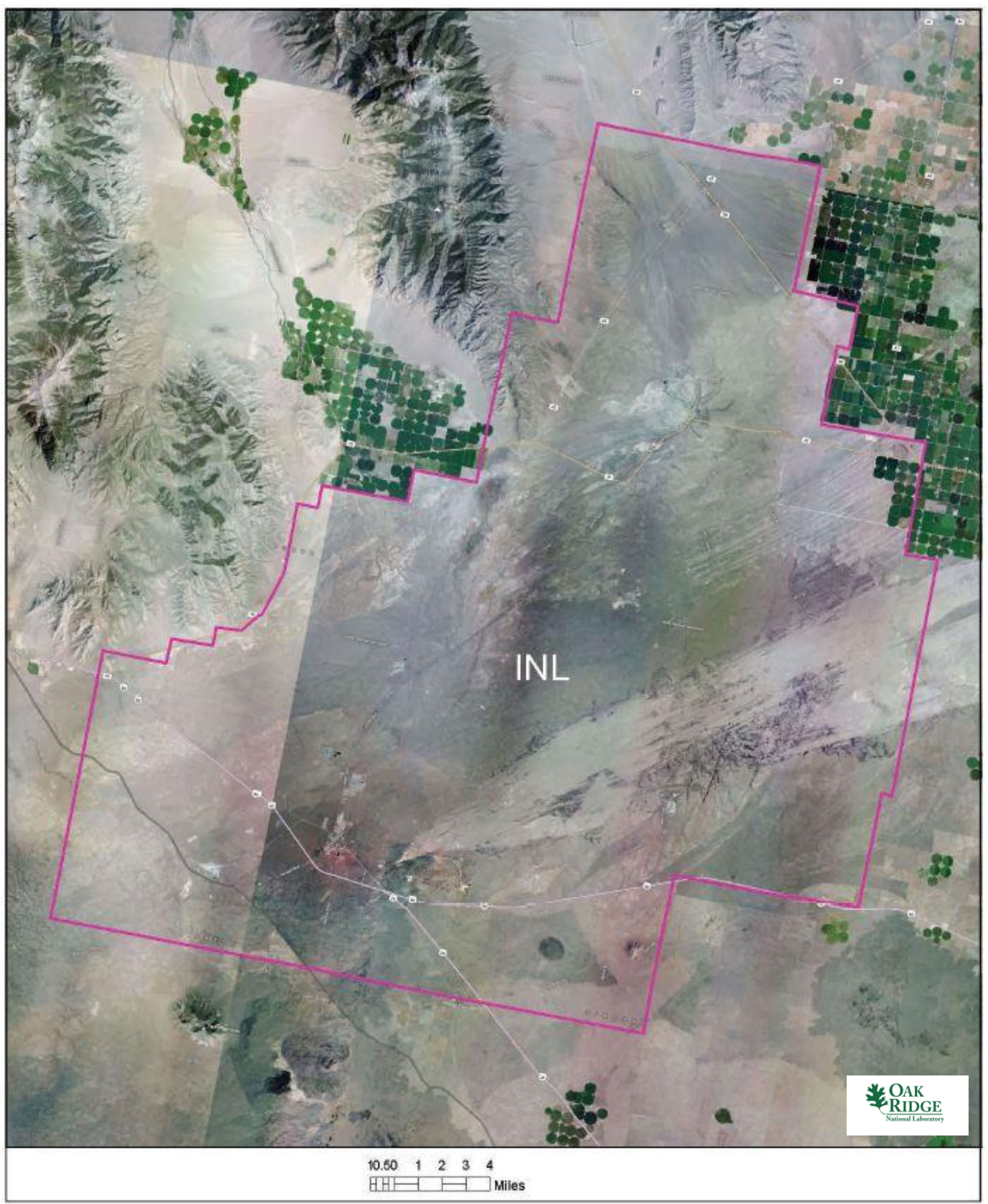

Fig. B.5. Satellite view of INL site area. 


\section{B.2.4 Screening Criteria Overview}

Table B.4 shows a screening criteria summary bar, or "dashboard" chart, for the site area provides a quick look at what siting issues may exist for the site. The criteria that are not met within the site area indicated.

Table B.4. Idaho National Laboratory site siting criteria summary

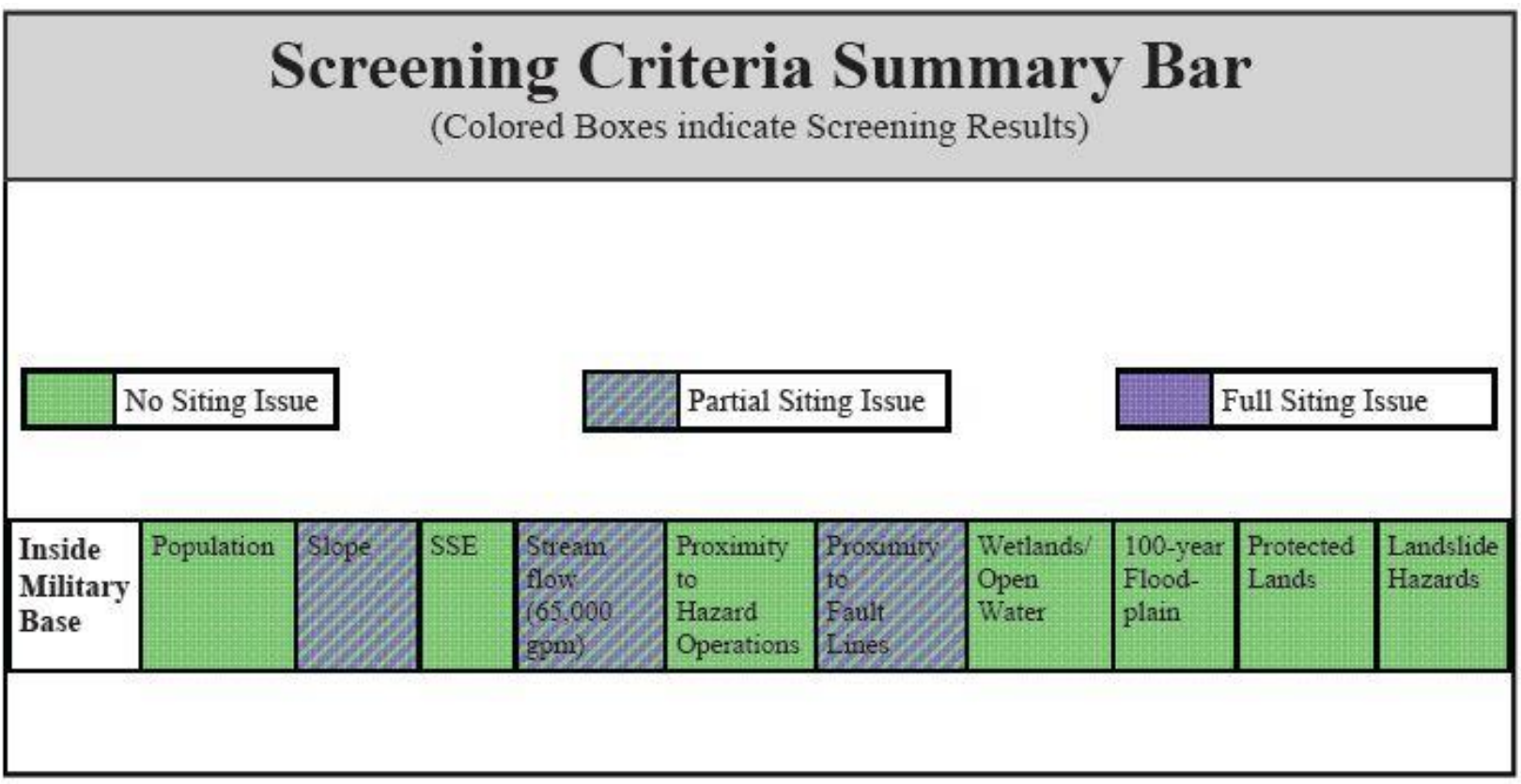

\begin{tabular}{|l|l|}
\hline \multicolumn{2}{|c|}{ Screening Criteria Table } \\
\hline \multicolumn{1}{|c|}{ Criteria } & Value \\
\hline Population Density within 10 miles (people/square mile) & $>500$ \\
\hline Slope & $>18 \%$ \\
\hline Safe shutdown earthquake (ground acceleration) & $>0.5$ \\
\hline Streamflow/cooling water make-up (gpm) & $<65,000$ \\
\hline Proximity to hazardous operations - buffer (mile) & Depends on hazardous operation ${ }^{1}$ \\
\hline Proximity to fault lines - buffer (mile) & Depends on length of fault \\
\hline Wetlands/Open Water & - \\
\hline 100-year floodplain & - \\
\hline Protected lands & \\
\hline Landslide hazard (moderate and high) & - \\
\hline
\end{tabular}

${ }^{1}$ Hazardous facilities (airports- 5 miles and oil refineries- -1 mile) 


\section{B.2.5 Composite Map and Individual Siting Issue Maps}

A composite map of SMR siting challenges to the INL site is shown in Fig. B.6. There are few siting challenges. Existing challenges are located near the northwest and southern peripheries of the site. Following this map are maps of the individual SMR siting criteria based on selected input values.

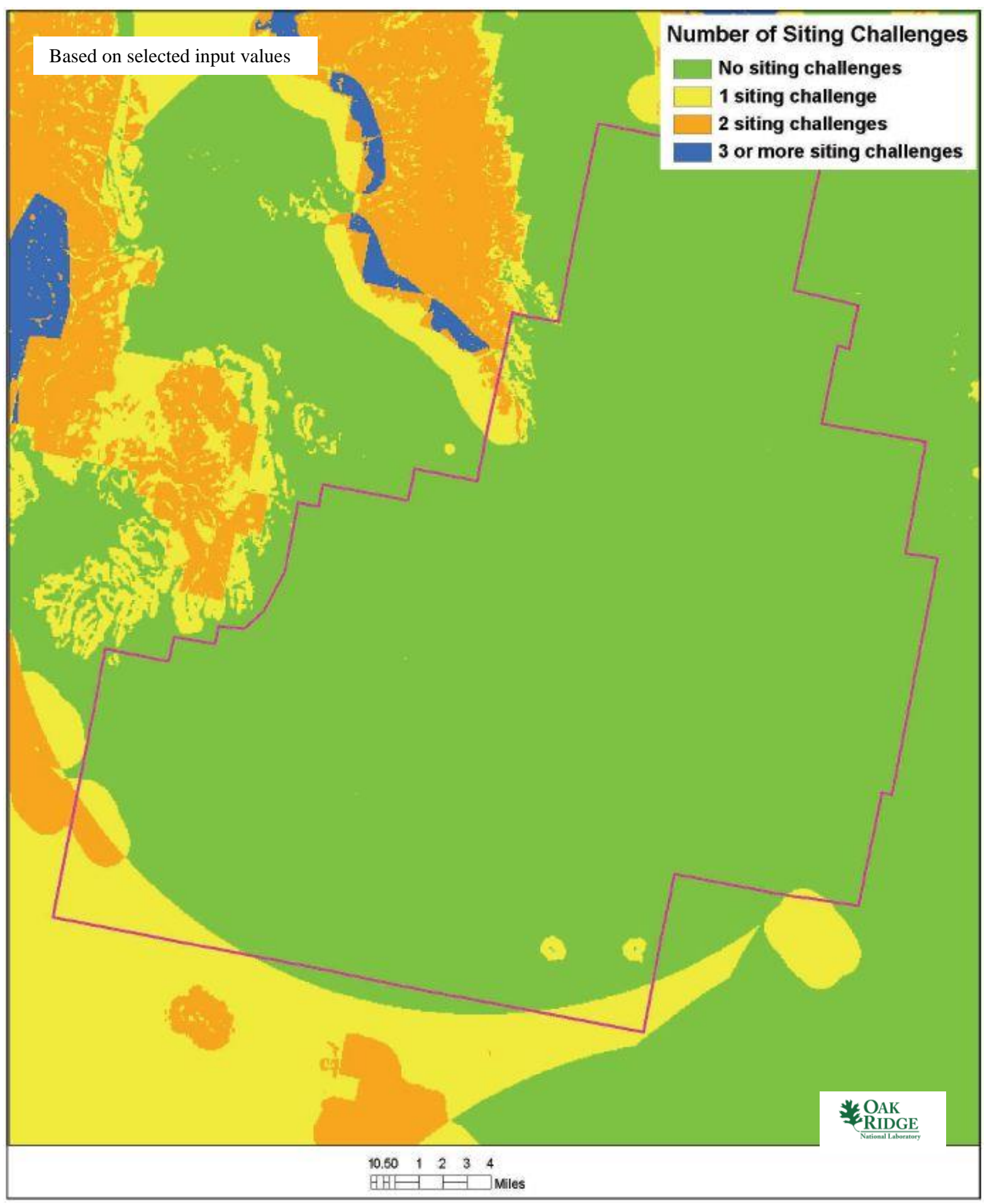

Fig. B.6. Idaho National Laboratory site composite map. 

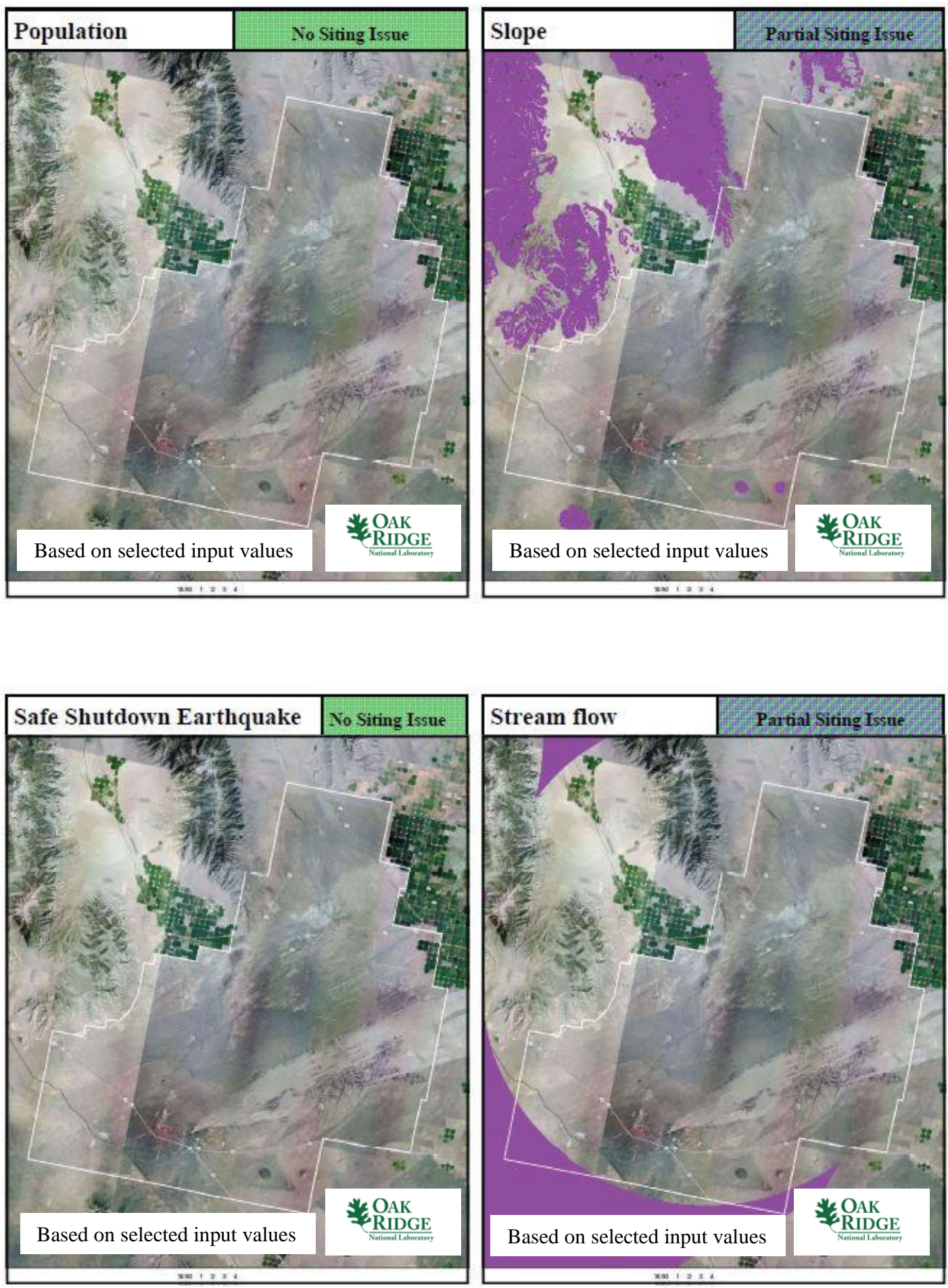

Idaho National Laboratory Site 

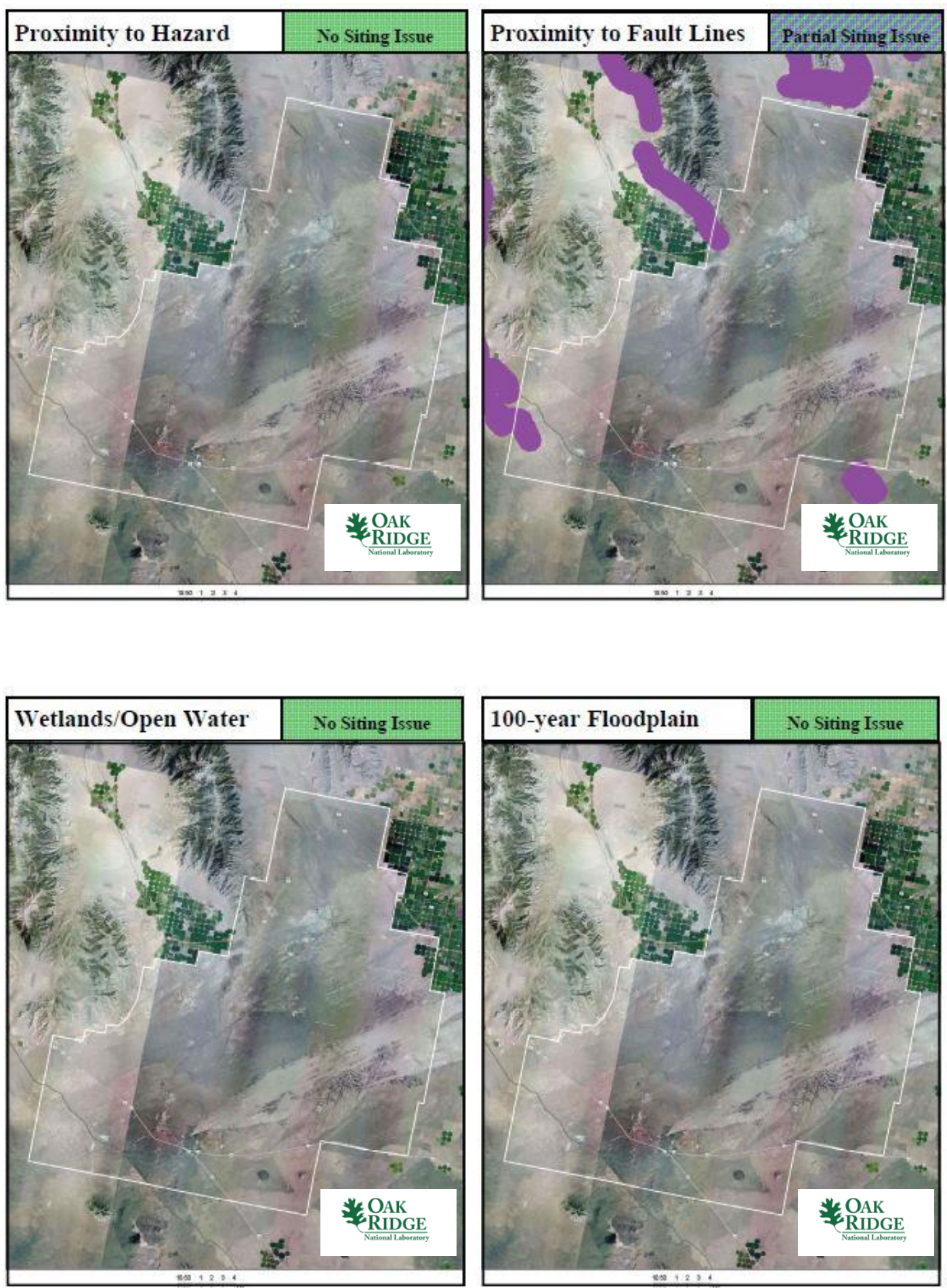

Idaho National Laboratory Site 

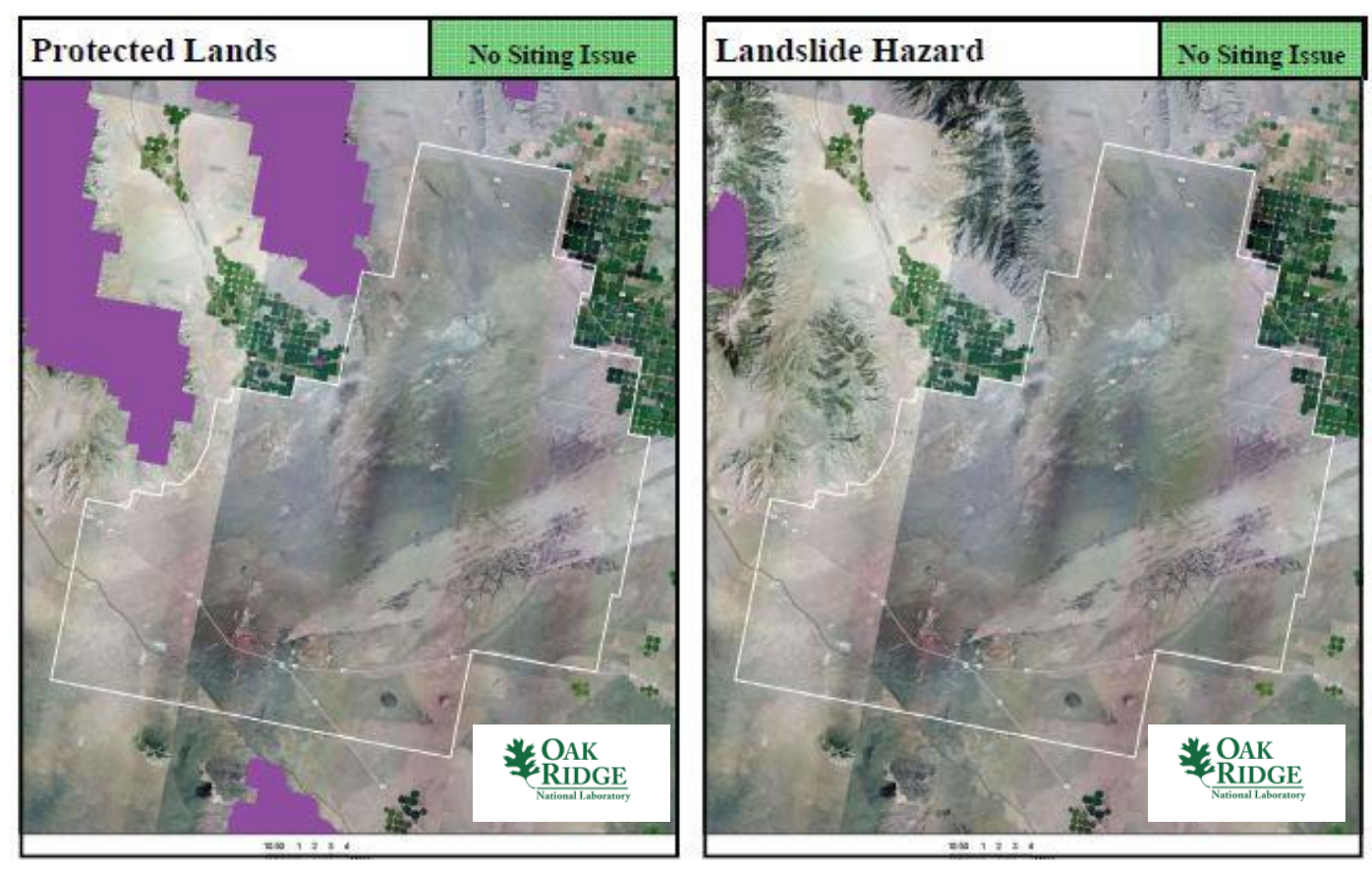

Idaho National Laboratory Site

\section{B.2.6 Site Evaluation}

The INL site is a large, federally controlled site. A well-trained, well-armed security force is available. Many of the activities and missions carried out on this site are high technology, science-based endeavors. Personnel working on the site would have considerable familiarity with the technology- and securityrelated operations associated with nuclear power plant operation. Power demands on the site associated with the national missions also are considerable and feasible for a site-located SMR. Over 50 reactors have been built on this site.

As shown in Sects. B.2.4 and B.2.5, the INL site has limited partial site issues. ${ }^{1}$ These concerns primarily affect the periphery of the site. Approximately $95 \%$ of the 570,000-acre site meets multiple conventional standards for consideration of siting an SMR on the DOE facility. Note, however, that the composite map does not reflect specific hazards associated with the site that could render some areas as unsuitable for siting a reactor.

The site meets current NRC RG 4.7 recommendations for population density without additional consideration for relaxed SMR population siting requirements based on reduced source term. This site should be classified as favorable for siting an SMR. 


\section{B.3 OAK RIDGE SITE}

\section{B.3.1 Location Detail}

As shown in Fig. B.7, the Oak Ridge site is a DOE site located on about 31,000 acres $^{6}$ (about 50 square miles) in East Tennessee near Oak Ridge, Tennessee. The Oak Ridge National Laboratory (ORNL), Y-12 National Security Complex, and the East Tennessee Technology Park (ETTP) (a former uranium enrichment facility) are located on the Oak Ridge Site. Highway 95 traverses north to south in the western half of the site. Highway 58 passes just south of the ETTP site area. Interstate 40 is just outside the southern perimeter of the site.

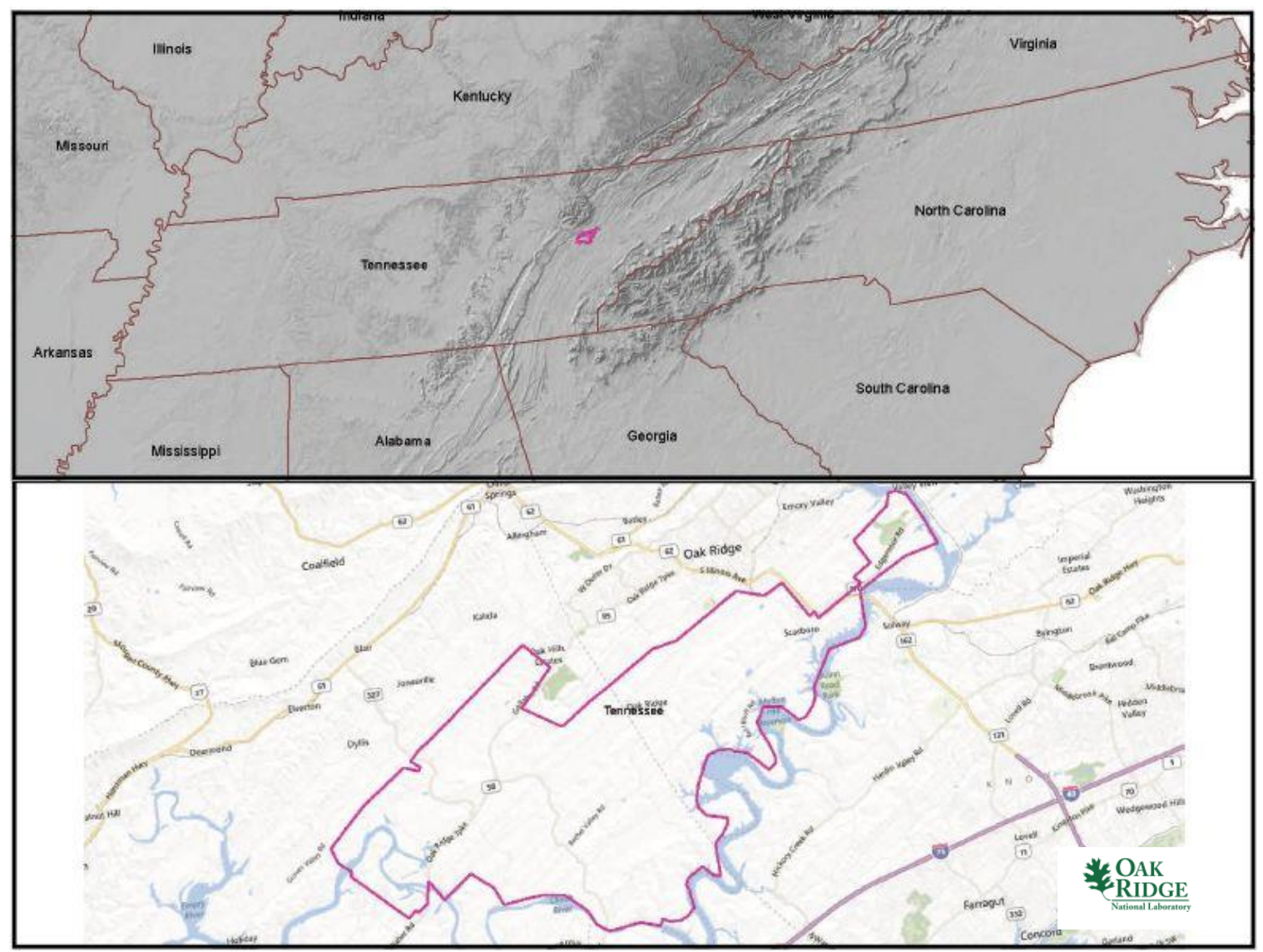

Fig. B.7. Oak Ridge site.

\section{B.3.2 Site Description and Status}

The Oak Ridge site is characterized by numerous ridges and valleys running northeast to southwest. It is a site long associated with a nuclear-related national security mission and science- and energy-related research. ORNL is the largest science and energy laboratory in the DOE system. Over the years, 13 nuclear reactors were built at the Oak Ridge Site. Oak Ridge National Laboratory's present research programs focus on materials, neutron science, energy, high-performance computing, systems biology, and national security. ${ }^{49}$ The mission of the National Nuclear Security Administration's (NNSA's) Y-12 National Security Complex centers on the processing and storage of uranium for national security purposes. Its core strengths are in areas of nuclear technology and materials, security and consequence

\footnotetext{
${ }^{49}$ http://www.ornl.gov/ornlhome/docs/fact.pdf
} 
management, and manufacturing and technical services. ${ }^{50}$ A large fraction of the site area associated with ORNL and the Y-12 National Security Complex has restricted access. The DOE's ETTP is presently home to two business centers located at a former gaseous diffusion plant site that is being cleaned up and developed for business or industrial use and has unrestricted, public access. ${ }^{51}$ There are approximately 10,000 employees across ORNL, Y-12 National Security Complex, and the ETTP.

As noted in Table B.5, the nearest major fault line based on USGS data is noted to be 742 miles west in Oklahoma. The maximum safe shutdown earthquake for the site is below $0.3 \mathrm{~g}$ peak ground acceleration. The maximum slope on the site is about $41 \%$. Greater than 500,000 gpm of cooling water makeup is available from the Clinch River. Major highways, rail, and water transport are nearby.

Table B.5. Oak Ridge Site statistics

\begin{tabular}{|l|l|l|l|}
\hline $\begin{array}{l}\text { Population } \\
\text { Population Within }\end{array}$ & \multicolumn{2}{l|}{$\begin{array}{l}\text { Utility } \\
\text { Distance to Grid Capacity }\end{array}$} \\
\hline $0.5 \mathrm{mi}$ of Site Boundary & $\sim 30,000$ & $>400 \mathrm{MWe}$ & $\sim 55 \mathrm{mi}$ \\
\hline $1 \mathrm{mi}$ of Site Boundary & $\sim 30,000$ & $>800 \mathrm{MWe}$ & $\sim 0.1 \mathrm{mi}$ \\
\hline 5 mi of Site Boundary & $\sim 30,000$ & $>1600 \mathrm{MWe}$ & $\sim 27 \mathrm{mi}$ \\
\hline 10 mi of Site Boundary & $\sim 30,000$ & $>3200 \mathrm{MWe}$ & $\sim 27 \mathrm{mi}$ \\
\hline Nearest City with Population & Distance to Cooling Water \\
\hline$>10,000$ & Oak Ridge, TN & $>50,000 \mathrm{gpm}$ & $\sim 0.1 \mathrm{mi}$ (Clinch River) \\
\hline$>50,000$ & Asheville, NC & $>100,000$ gpm & $\sim 0.1 \mathrm{mi}$ (Clinch River) \\
\hline$>100,000$ & Knoxville, TN & $>200,000$ gpm & $\sim 0.1 \mathrm{mi}$ (Clinch River) \\
\hline$>500,000$ & Nashville, TN & $>500,000$ gpm & $\sim 0.1 \mathrm{mi}$ (Clinch River) \\
\hline Geotechnical & & Accessibility & \\
\hline Max Earthquake Acceleration & $<0.3 \mathrm{~g}$ & Distance to Major Roadway & $\sim 0.1 \mathrm{mi}$ (SR 62) \\
\hline Max Slope & $\sim 41 \%$ & Distance to Water Transport & $\sim 0.1 \mathrm{mi}$ (Clinch River) \\
\hline Nearest Fault Line & $\sim 742$ mi (Oklahoma) & Distance to Rail Transport & $\sim 0.1 \mathrm{mi}$ (USG) \\
\hline Nearest Hazard Site & $\sim 15$ mi (Airport-McGhee & Distance to Airport & $\sim 15 \mathrm{mi}$ (McGhee Tyson) \\
\hline
\end{tabular}

\section{B.3.3 Aerial Imagery}

The aerial imagery in Fig. B.8 indicates the Y-12 National Security Complex is located in the northeast area of the main site area adjacent to the city of Oak Ridge. The ETTP is located in the western area of the site. ORNL is in the central western of the site.

\footnotetext{
${ }^{50} \mathrm{http}: / /$ www.y12.doe.gov/about/

${ }^{51}$ http://www.ETTPreuse.com/
} 


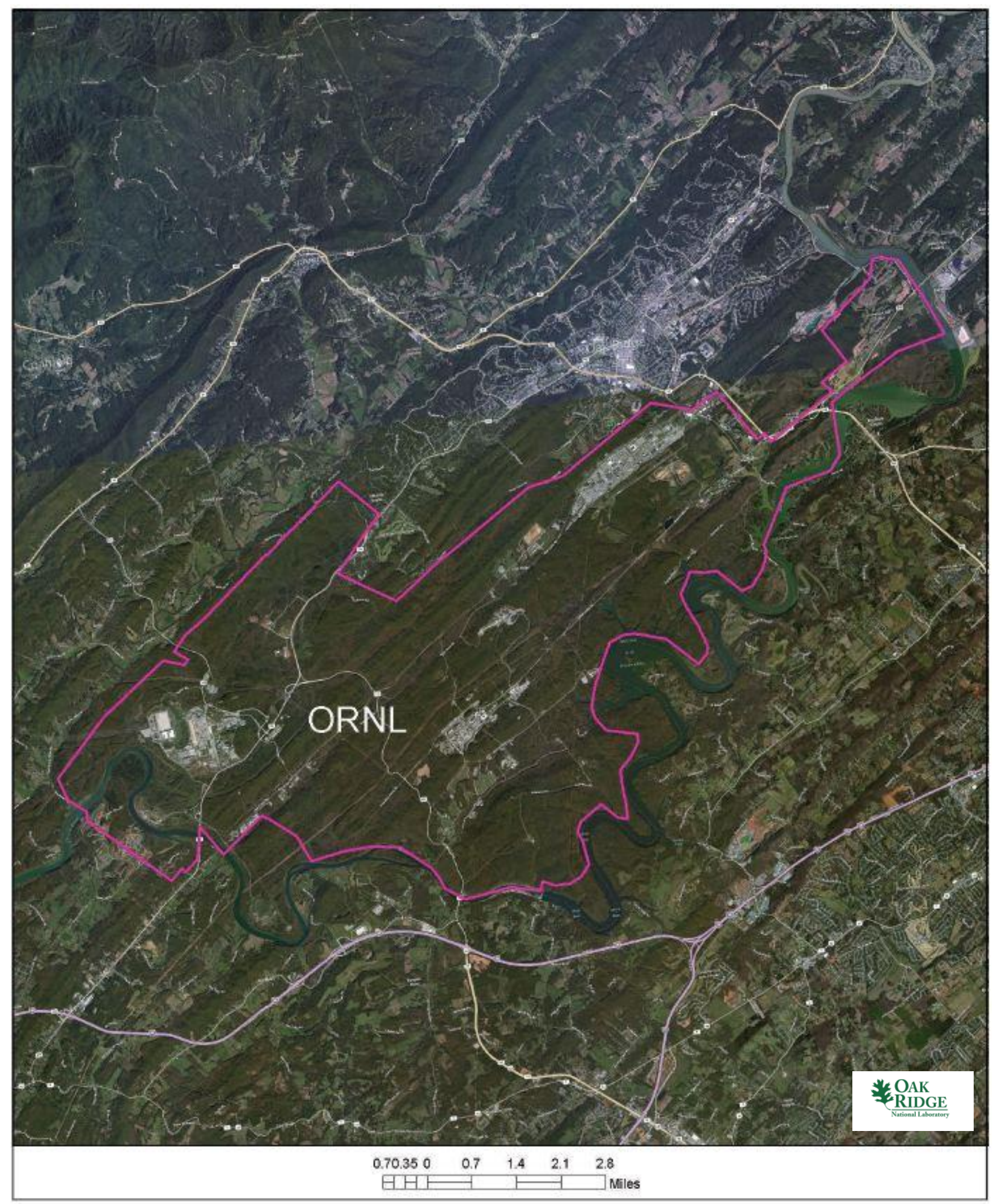

Fig. B.8. Satellite view of Oak Ridge site area. 


\section{B.3.4 Screening Criteria Overview}

Table B.6 shows a screening criteria summary bar, or "dashboard" chart, for the site area provides a quick look at what siting issues may exist for the site. The criteria that are not met within the site area indicated.

Table B.6. Oak Ridge site siting criteria summary

\section{Screening Criteria Summary Bar}

(Colored Boxes indicate Screening Results)

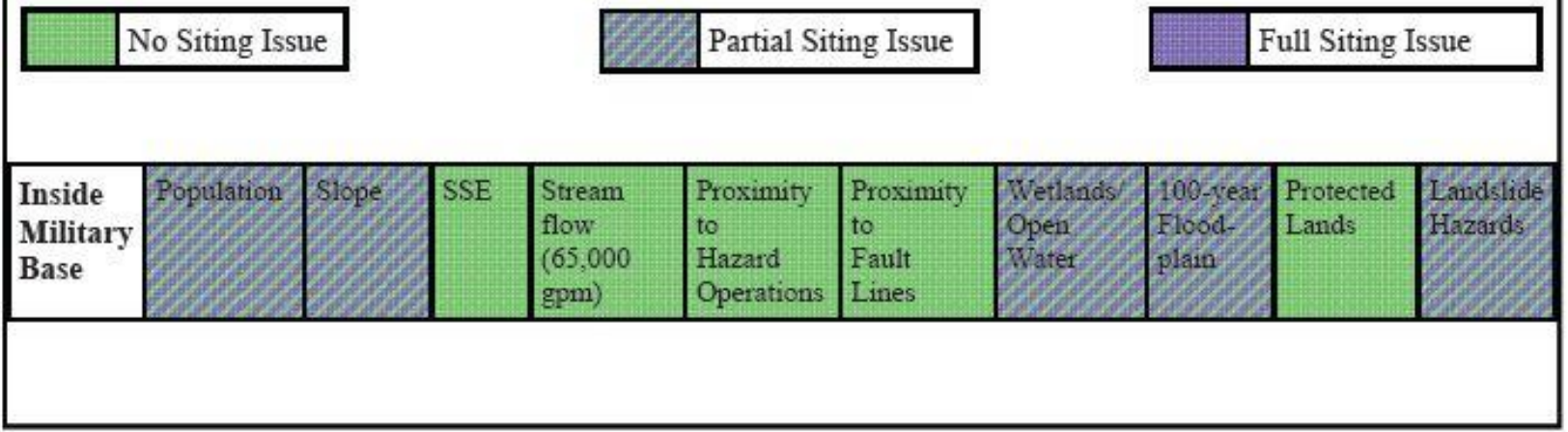

\begin{tabular}{|l|l|}
\hline \multicolumn{2}{|c|}{ Screening Criteria Table } \\
\hline \multicolumn{1}{|c|}{ Criteria } & Value \\
\hline Population Density within 10 miles (people/square mile) & $>500$ \\
\hline Slope & $>18 \%$ \\
\hline Safe shutdown earthquake (ground acceleration) & $>0.5$ \\
\hline Streamflow/cooling water make-up (gpm) & $<65,000$ \\
\hline Proximity to hazardous operations - buffer (mile) & Depends on hazardous operation ${ }^{1}$ \\
\hline Proximity to fault lines - buffer (mile) & Depends on length of fault \\
\hline Wetlands/Open Water & - \\
\hline 100-year floodplain & - \\
\hline Protected lands & - \\
\hline Landslide hazard (moderate and high) & - \\
\hline
\end{tabular}

${ }^{1}$ Hazardous facilities (airports-5 miles and oil refineries-1 mile) 


\section{B.3.5 Composite Map and Individual Siting Issue Maps}

A composite map of SMR siting challenges to the Oak Ridge Site is shown in Fig. B.9. Siting challenges are predominantly in the north and east areas of the site. Following this map are maps of the individual SMR siting criteria based on selected input values.

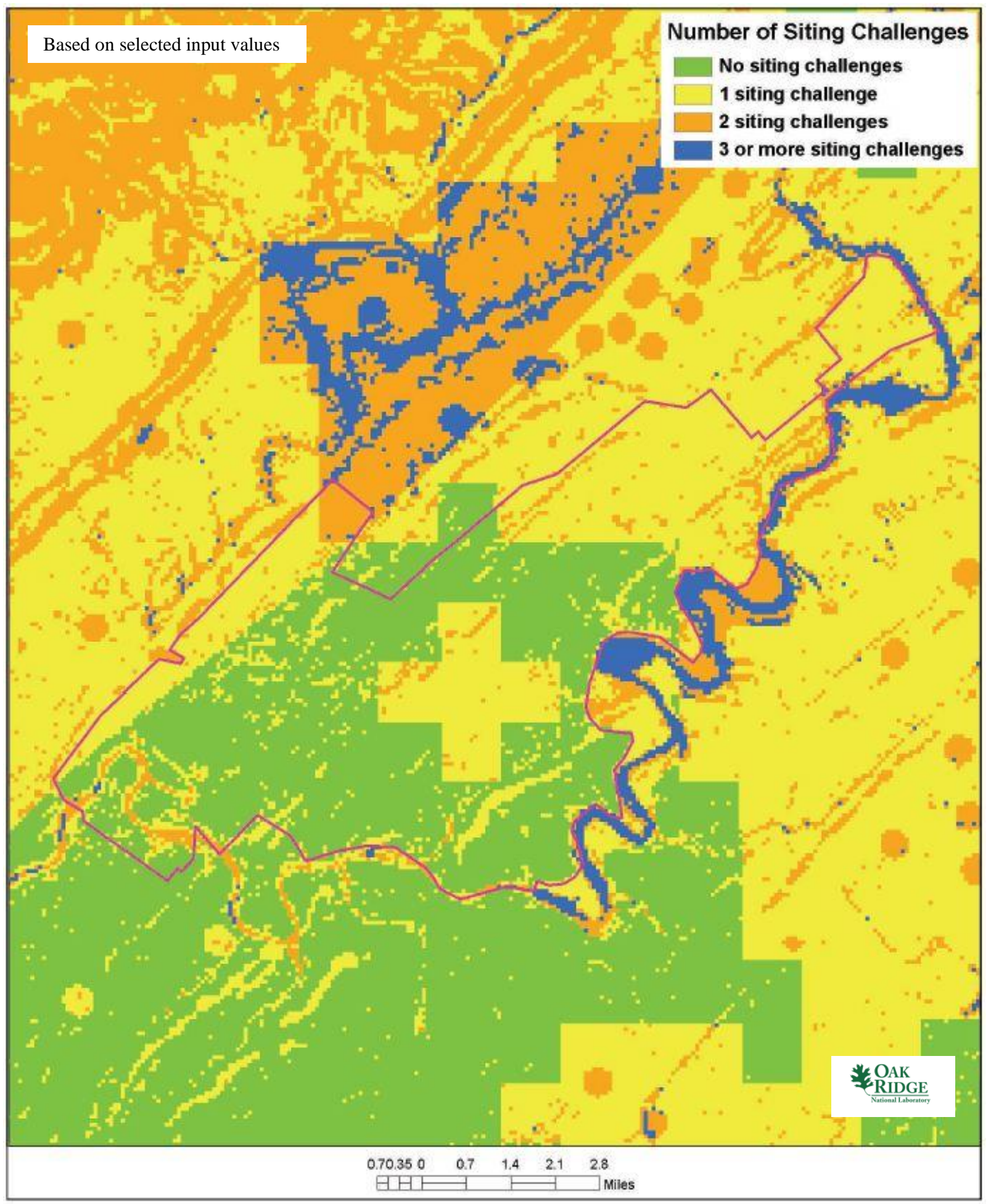

Fig. B.9. Oak Ridge site composite map. 

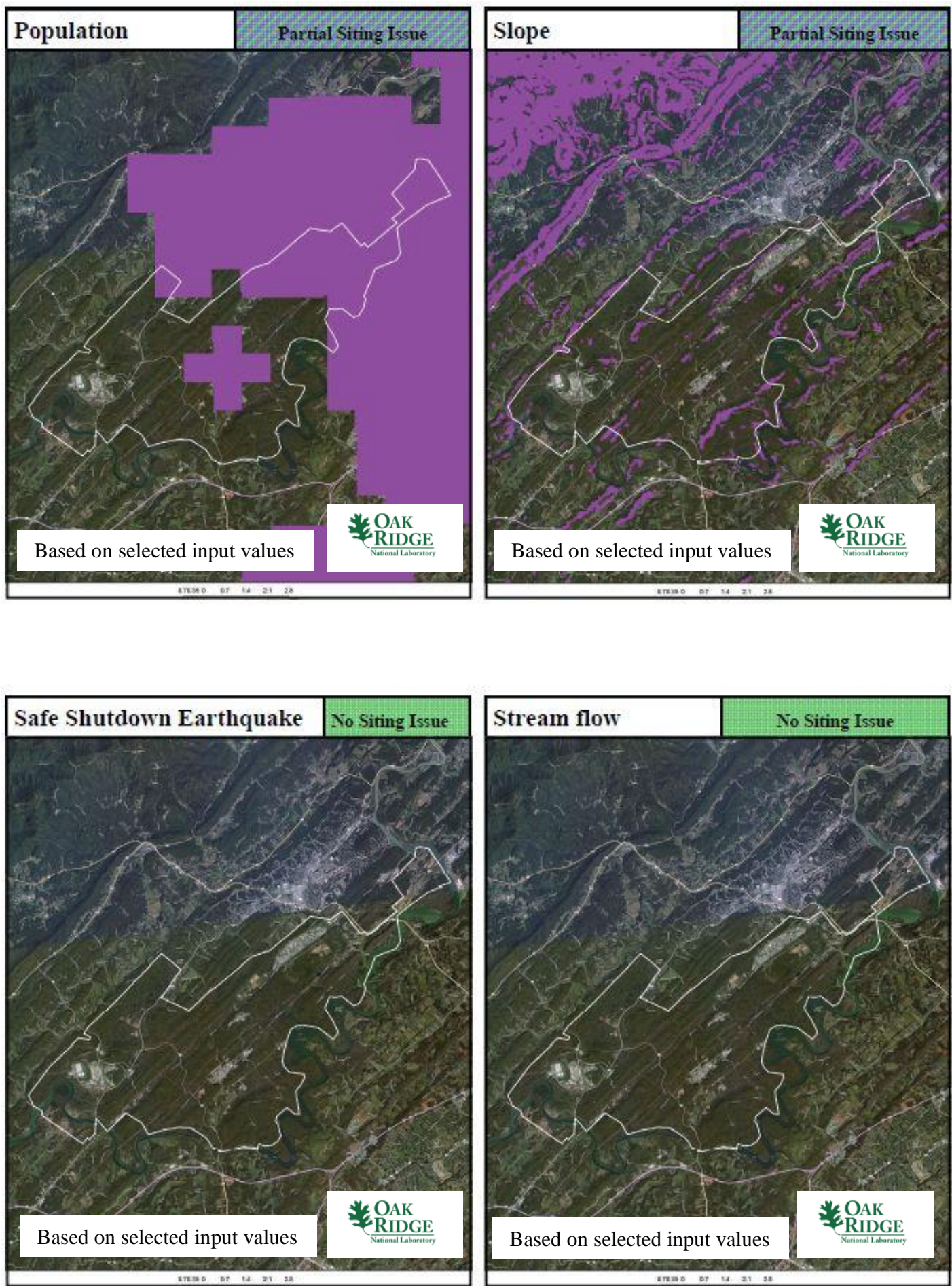

Oak Ridge Site 

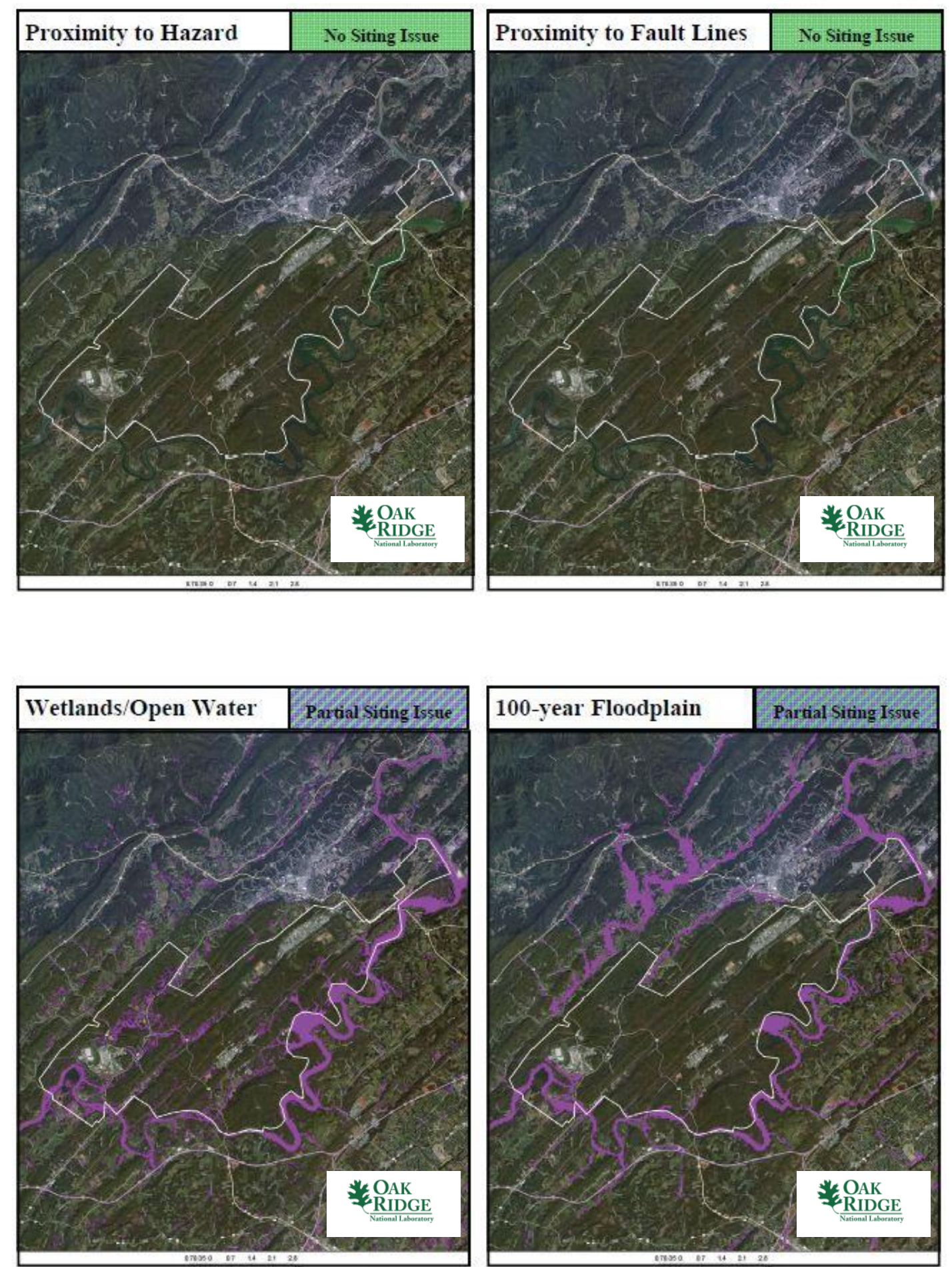

Oak Ridge Site 

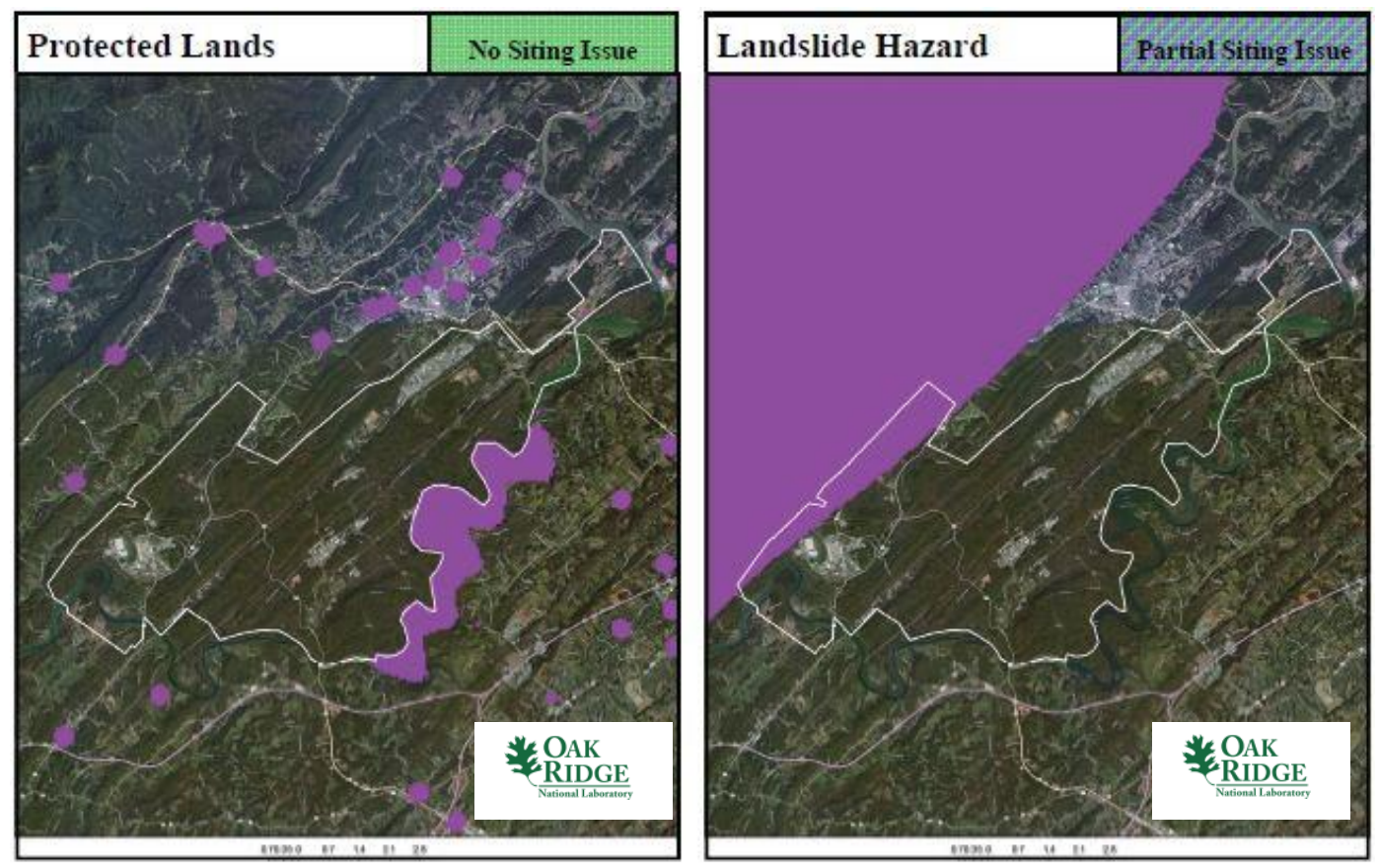

Oak Ridge Site

\section{B.3.6 Site Evaluation}

The Oak Ridge site is a large, federally controlled site. A well-trained, well-armed security force is available. Many of the activities and missions carried out on this site are high technology, science-based endeavors. Personnel working on the site would have considerable familiarity with the technology- and security-related operations associated with nuclear power plant operation. Power demands on the site associated with the national missions and private industry and business are considerable and feasible for a site-located SMR. Thirteen reactors have been built on the site.

As shown in Sects. B.3.4 and B.3.5, the Oak Ridge site has partial site issues with population, slope, and wetlands/open waters. ${ }^{1}$ Population affects areas to the north, while the other concerns affect areas throughout the site. Approximately 50\% of the 31,000-acre site meets multiple conventional standards for consideration of siting an SMR on the DOE facility. A "plus" shaped area in the central area of the site represents the large and concentrated work force population at the ORNL site. Note, however, that the composite map does not reflect specific hazards associated with the site, such as storage areas, landfills, facilities, etc., which could render some areas as unsuitable for siting a reactor.

The site meets current NRC RG 4.7 recommendations for population density without additional consideration for relaxed SMR population siting requirements based on reduced source term. This site should be classified as favorable for siting an SMR.

The Oak Ridge site is a potential market for a small modular reactor being planned by TVA at the former Clinch River Breeder Reactor site located just a few miles west of the site. 


\section{B.4 SANDIA SITE}

\section{B.4.1 Location Detail}

As shown in Fig. B.10, Sandia site is located on about 25,000 acres ${ }^{6}$ (about 40 square miles) a few miles southeast of Albuquerque, New Mexico. The site includes the Albuquerque International Airport on the west side of the site, Sandia National Laboratories (SNL), DOE/NNSA, Defense Threat Reduction Agency, and Kirtland Air Force Base. Sandia Corporation operates SNL for the DOE, NNSA. SNL provides science-, technology-, and engineering-oriented missions for federal, state, and local government agencies and academic institutions, and private industry under certain conditions. Missions include nuclear weapons; defense systems and assessments; energy, climate, and infrastructure security; and international, homeland, and nuclear security. ${ }^{52}$ Interstate 25 is just west of the site. Interstate 40 is just north.

Kirtland Air Force Base is home to the Air Force Materiel Command's Nuclear Weapons Center, whose mission is to ensure the safety, security, and reliability of US nuclear weapons systems, and many other elements.

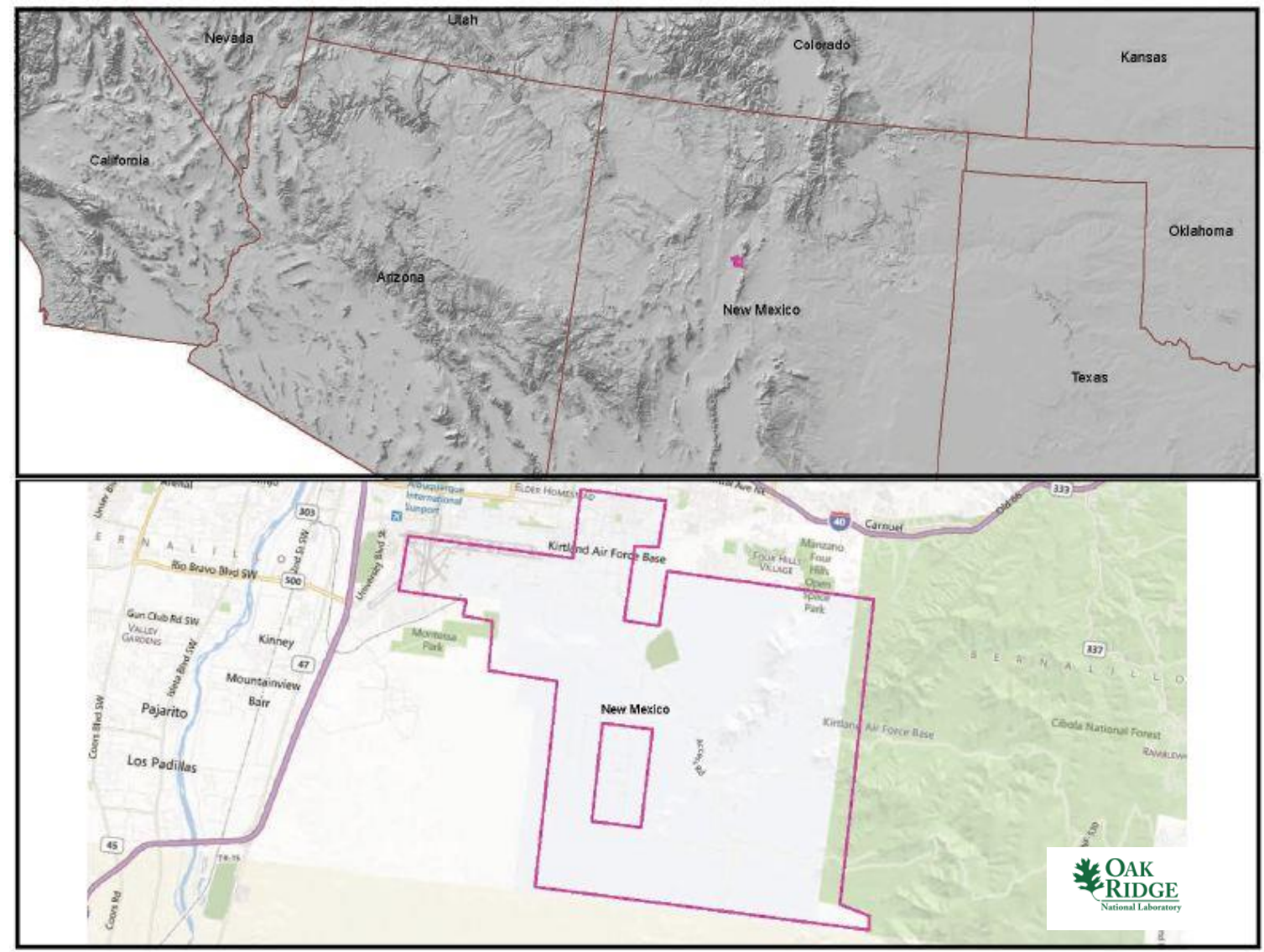

Fig. B.10. Sandia site.

\footnotetext{
${ }^{52} \mathrm{http}: / /$ www.sandia.gov/about/index.html
} 


\section{B.4.2 Site Description and Status}

The Sandia site is adjacent to the city of Albuquerque, New Mexico, which has a population of approximately 550,000 people based on the 2011 US Census. The population of the metropolitan area is almost 900,000 people.

The site itself has approximately 35,000 military personnel, scientists, engineers, support personnel, and contractors. Descriptions of the various institutions on the site are readily available on the Internet. ${ }^{1,53,54}$

As noted in Table B.7, the nearest major fault line is on-site. The maximum safe shutdown earthquake for the site is below $0.3 \mathrm{~g}$ peak ground acceleration. The maximum slope on the site is about $60 \%$. The nearest source of water with greater than 50,000 gpm of cooling water makeup is the Rio Grande River (shown in Table B.7 as Grande Rio), which is 38 miles away. Major highways and rail transport are nearby.

Table B.7. Sandia site statistics

\begin{tabular}{|l|l|l|l|}
\hline $\begin{array}{l}\text { Population } \\
\text { Population Within }\end{array}$ & \multicolumn{2}{l|}{$\begin{array}{l}\text { Utility } \\
\text { Distance to Grid Capacity }\end{array}$} \\
\hline $0.5 \mathrm{mi}$ of Site Boundary & $\sim 61,000$ & $>400 \mathrm{MWe}$ & $\sim 17 \mathrm{mi}$ \\
\hline $1 \mathrm{mi}$ of Site Boundary & $\sim 61,000$ & $>800 \mathrm{MWe}$ & $\sim 19 \mathrm{mi}$ \\
\hline $5 \mathrm{mi}$ of Site Boundary & $\sim 61,000$ & $>1600 \mathrm{MWe}$ & $\sim 281 \mathrm{mi}$ \\
\hline 10 mi of Site Boundary & $\sim 61,000$ & $>3200 \mathrm{MWe}$ & $\sim 281 \mathrm{mi}$ \\
\hline Nearest City with Population & Distance to Cooling Water \\
\hline$>10,000$ & South Valley, NM & $>50,000$ gpm & $\sim 38 \mathrm{mi}$ (Grande Rio) \\
\hline$>50,000$ & Rio Rancho, NM & $>100,000$ gpm & $\sim 38$ mi (Grande Rio) \\
\hline$>100,000$ & Pueblo, CO & $>200,000$ gpm & $\sim 38$ mi (Grande Rio) \\
\hline$>500,000$ & Albuquerque, NM & $>500,000$ gpm & $\sim 38$ mi (Grande Rio) \\
\hline Geotechnical & & Accessibility & \\
\hline Max Earthquake Acceleration & $<0.3 \mathrm{~g}$ & Distance to Major Roadway & $\sim 1 \mathrm{mi}$ (Interstate 25) \\
\hline Max Slope & $\sim 60 \%$ & Distance to Water Transport & $\sim 531 \mathrm{mi}$ (Arkansas River) \\
\hline Nearest Fault Line & On Site & Distance to Rail Transport & $\sim 2 \mathrm{mi}$ (BNSF) \\
\hline Nearest Hazard Site & $\sim 0.1$ mi (Airport- & Distance to Airport & $\sim 0.1$ mi (Albuquerque Intl \\
\hline
\end{tabular}

\section{B.4.3 Aerial Imagery}

The aerial imagery in Fig. B.11 indicates the areas of population density in the areas north and west of the site. Numerous facilities, buildings, storage areas, and bunkers are located on the site.

\footnotetext{
${ }^{53}$ http://kirtland.af.mil

${ }^{54}$ http://en.wikipedia.org/wiki/Kirtland_Air_Force_Base
} 


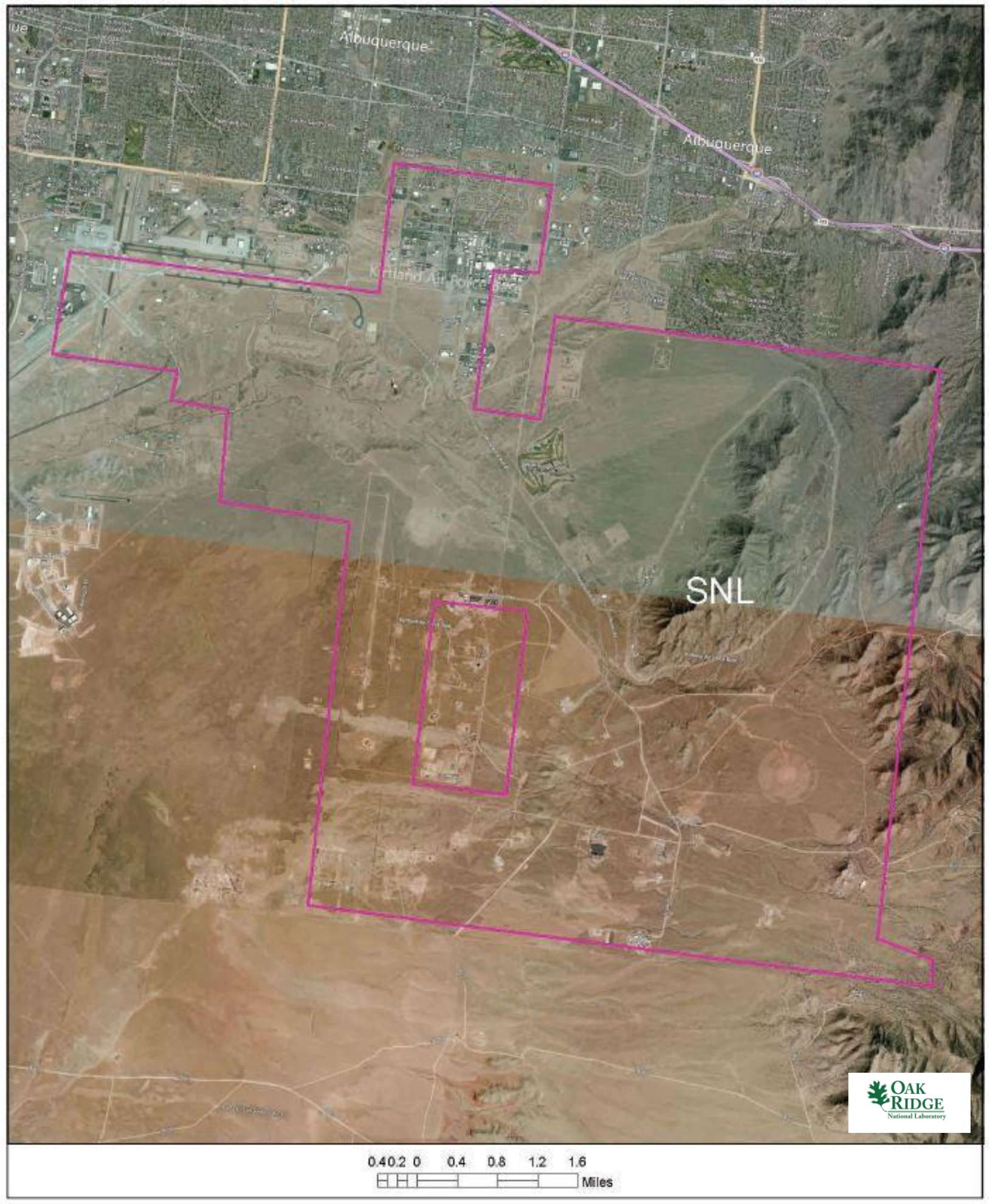

Fig. B.11. Satellite view of Sandia site area. 


\section{B.4.4 Screening Criteria Overview}

Table B. 8 shows a screening criteria summary bar, or "dashboard" chart, for the site area provides a quick look at what siting issues may exist for the site. The criteria that are not met within the site area indicated.

Table B.8. Sandia site siting criteria summary

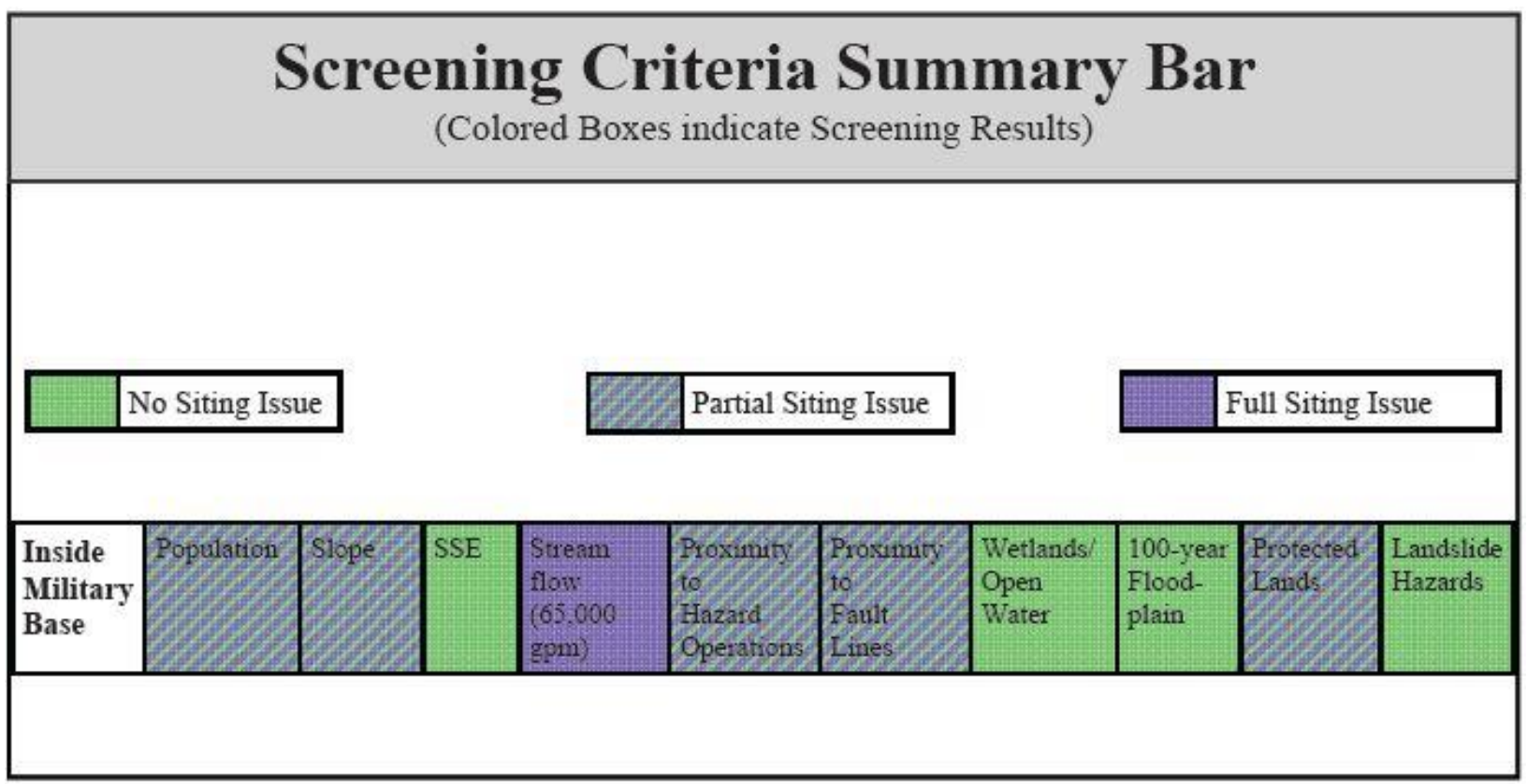

\begin{tabular}{|l|c|}
\hline \multicolumn{2}{|c|}{ Screening Criteria Table } \\
\hline \multicolumn{1}{|c|}{ Criteria } & Value \\
\hline Population Density within 10 miles (people/square mile) & $>500$ \\
\hline Slope & $>18 \%$ \\
\hline Safe shutdown earthquake (ground acceleration) & $>0.5$ \\
\hline Streamflow/cooling water make-up (gpm) & $<65,000$ \\
\hline Proximity to hazardous operations - buffer (mile) & Depends on hazardous operation ${ }^{1}$ \\
\hline Proximity to fault lines - buffer (mile) & Depends on length of fault \\
\hline Wetlands/Open Water & - \\
\hline 100-year floodplain & - \\
\hline Protected lands & \\
\hline Landslide hazard (moderate and high) & - \\
\hline
\end{tabular}

${ }^{1}$ Hazardous facilities (airports-5 miles and oil refineries-1 mile) 


\section{B.4.5 Composite Map and Individual Siting Issue Maps}

A composite map of SMR siting challenges to the Sandia Site is shown in Fig. B.12. Siting challenges are present for the entire site. Following this map are maps of the individual SMR siting criteria based on selected input values.

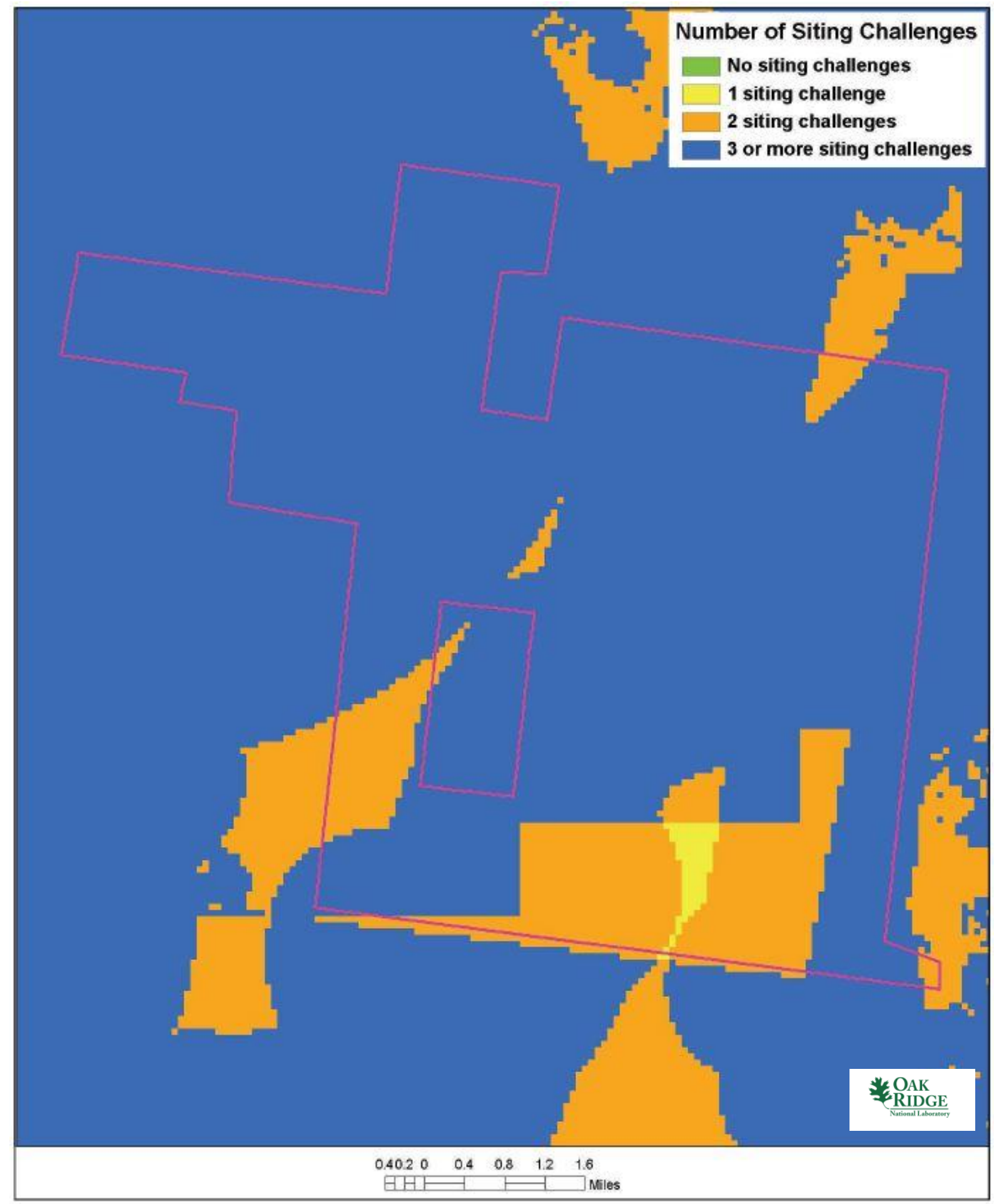

Fig. B.12. Sandia site composite map. 

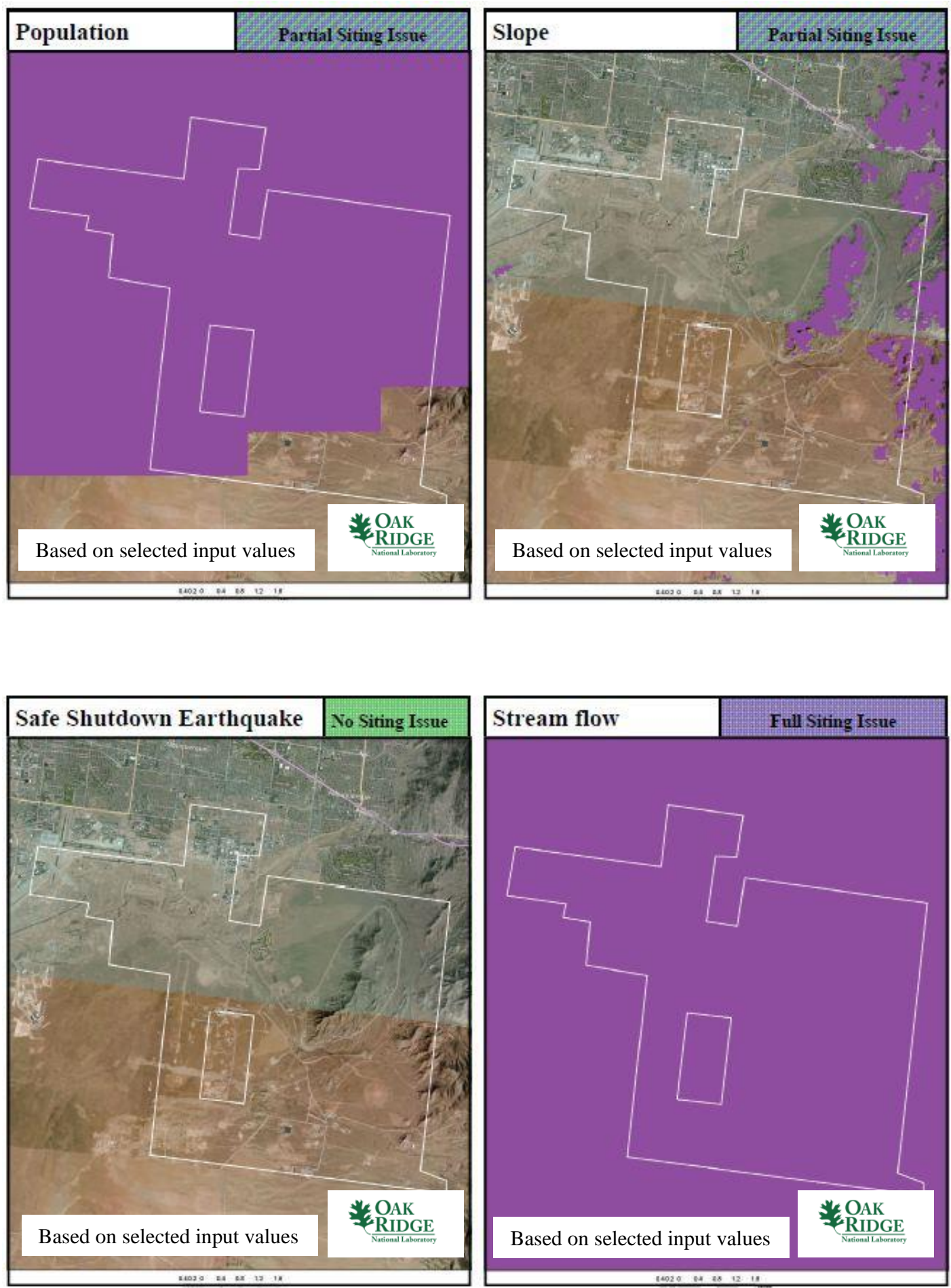

Sandia Site 

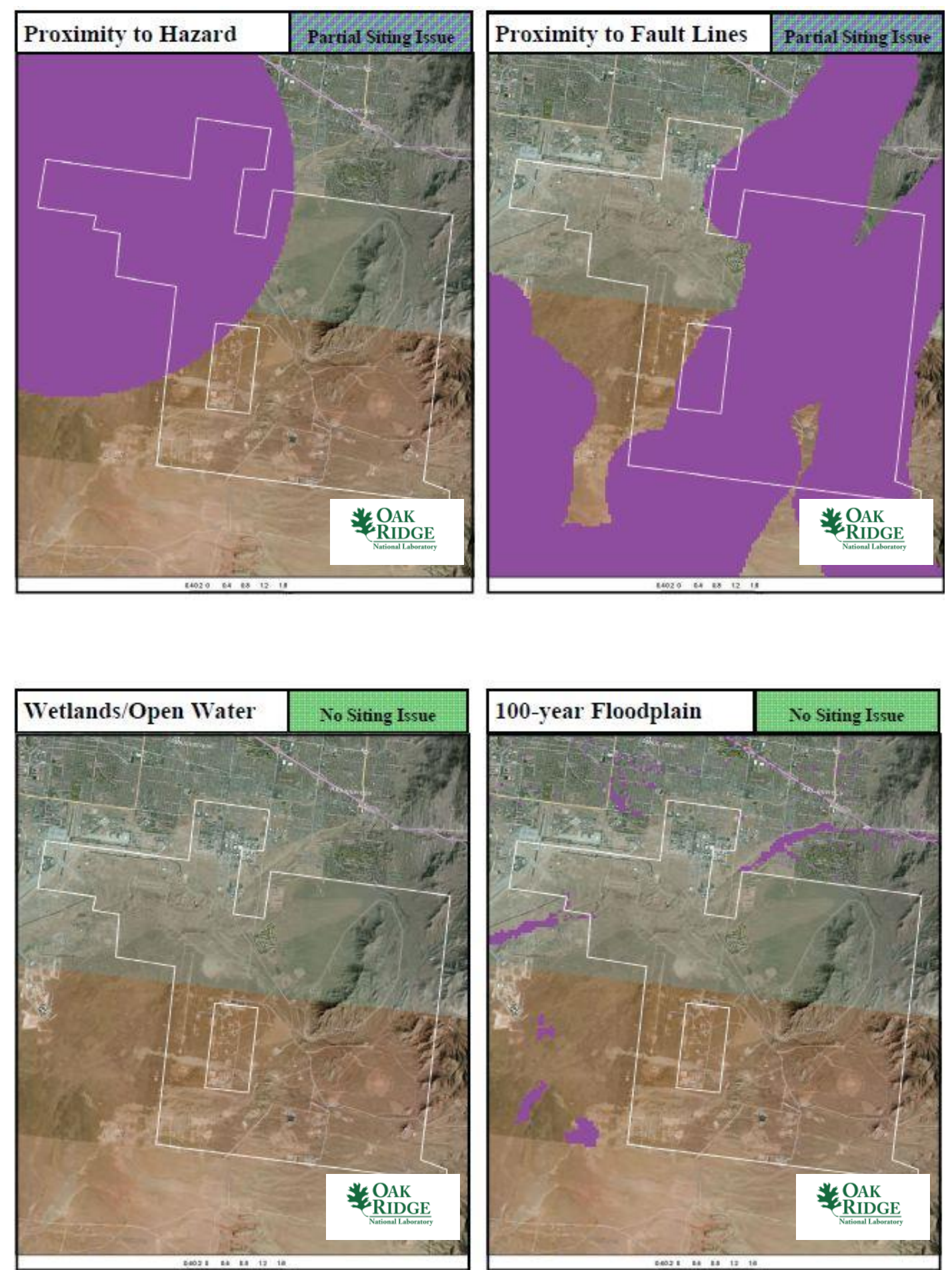

Sandia Site 

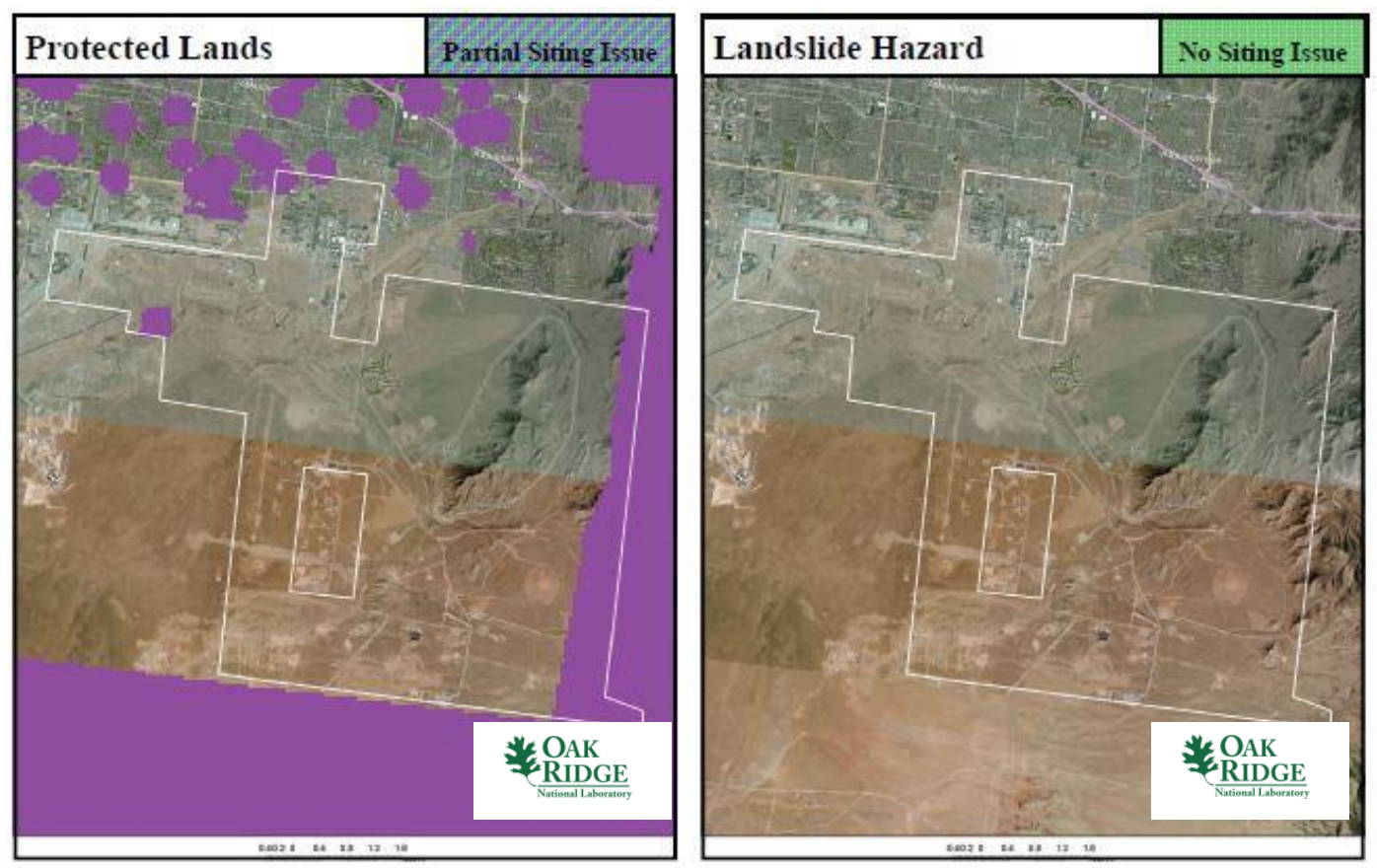

Sandia Site

\section{B.4.6 Site Evaluation}

The Sandia site is a large, federally controlled site. A well-trained, well-armed security force is available. Many of the activities and missions carried out on this site are high technology, science-based endeavors. Personnel working on the site would have considerable familiarity with the technology- and securityrelated operations associated with nuclear power plant operation. Power demands on the site associated with the national missions and private industry and business are considerable and feasible for a sitelocated SMR.

As shown in Sects. B.4.4 and B.4.5, the Sandia site has a full site issue with stream flow. ${ }^{1}$ The nearest source of water with sufficient flow is from the Rio Grande River approximately 38 miles away. There is an aquifer in this part of New Mexico and there is the potential for using gray water (treated waste water) as the source of cooling water makeup from the city of Albuquerque. However, these sources of cooling water makeup for an SMR were not considered in this analysis. It is likely that water rights associated with the Rio Grande River are highly regulated and the availability of gray water as a source of cooling water makeup is unknown.

The Sandia site also has partial SMR site screening issues with population, slope, proximity to the Albuquerque airport (hazard), proximity to fault lines, and proximity to protected lands. ${ }^{1}$ Most of these screening issues overlap. There is only one small area in the southeast corner of the site that is impacted by just a single SMR siting concern (inadequate stream flow).

Therefore, this site is not a likely candidate for consideration of siting an SMR. 


\section{B.5 SAVANNAH RIVER SITE}

\section{B.5.1 Location Detail}

As shown in Fig. B.13, the Savannah River site (SRS) is a DOE site located on about 200,000 acres ${ }^{6}$ (about 310 square miles) in South Carolina on the border with Georgia. Augusta, Georgia, is about 15 miles northwest from the perimeter of the site. Aiken, South Carolina, is about 10 miles north of the perimeter of the site. Site organizations include the DOE Savannah River Operations Office, Savannah River National Laboratory, Savannah River Nuclear Solutions, LLC, Savannah River Remediation, LLC, Savannah River Ecology Laboratory, and others. Major missions of these organizations are national security, clean energy, and environmental stewardship.

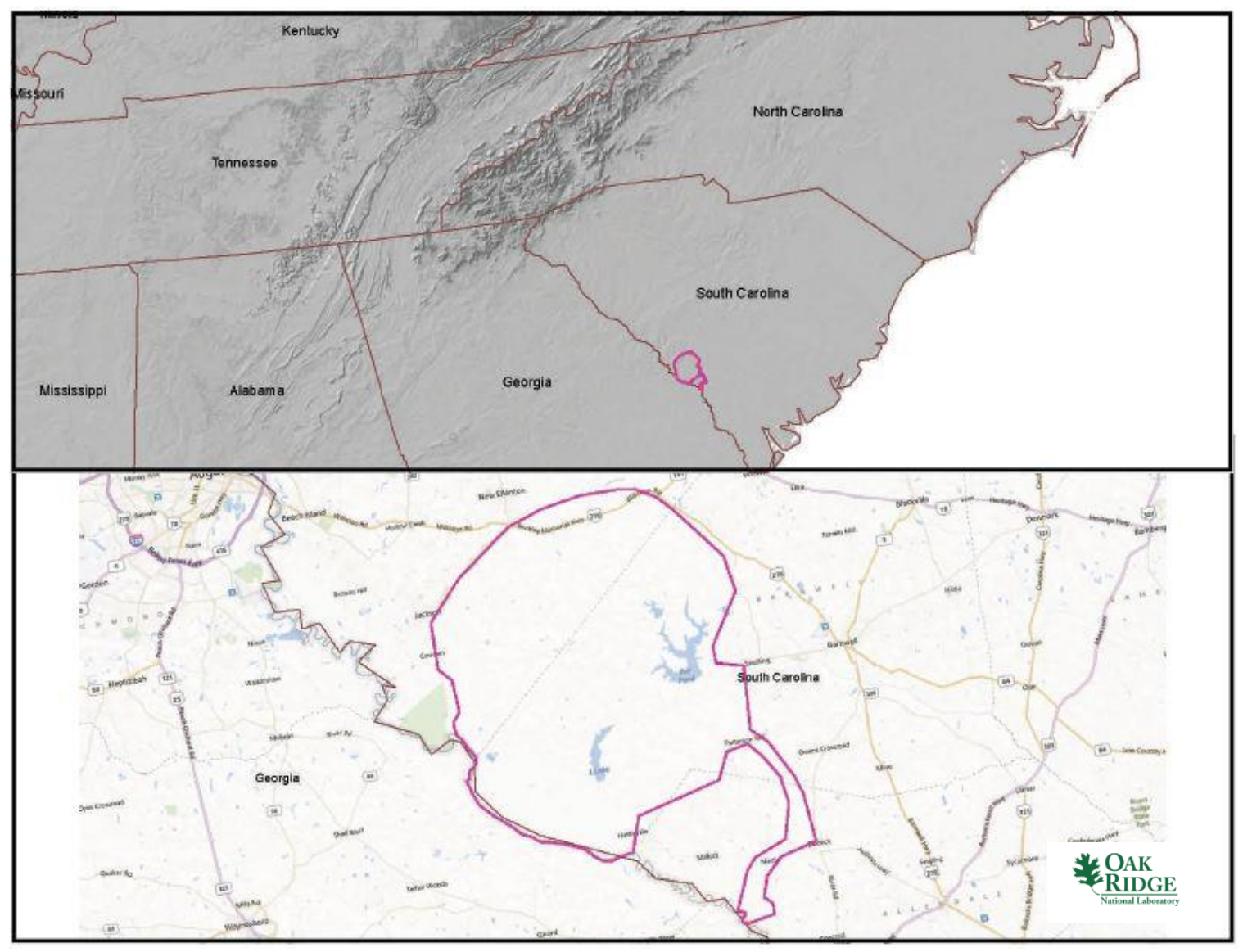

Fig. B.13. Savannah River site.

\section{B.5.2 Site Description and Status}

The SRS is a site long associated with a nuclear-related national security mission. Five reactors were built at SRS to produce nuclear weapons materials, plus related chemical separations plants, fuel fabrication facilities, and waste management facilities. ${ }^{55}$ The site workforce numbers about 12,000 people.

\footnotetext{
${ }^{55}$ http://www.srs.gov/general/about/history1.htm
} 
As noted in Table B.9, the nearest major fault line based on USGS data is noted to be 900 miles west in Oklahoma. The maximum safe shutdown earthquake for the site is below $0.3 \mathrm{~g}$ peak ground acceleration. The maximum slope on the site is about $14 \%$. Greater than 500,000 gpm of cooling water makeup is available from the Savannah River that forms the southwest boundary of the site. Major highways, rail transport, and water transport are nearby.

\section{Table B.9. Savannah River Site statistics}

\begin{tabular}{|l|l|l|l|}
\hline $\begin{array}{l}\text { Population } \\
\text { Population Within }\end{array}$ & \multicolumn{2}{l|}{$\begin{array}{l}\text { Utility } \\
\text { Distance to Grid Capacity }\end{array}$} \\
\hline $0.5 \mathrm{mi}$ of Site Boundary & $\sim 29,500$ & $>400 \mathrm{MWe}$ & $\sim 0.1 \mathrm{mi}$ \\
\hline $1 \mathrm{mi}$ of Site Boundary & $\sim 29,500$ & $>800 \mathrm{MWe}$ & $\sim 48 \mathrm{mi}$ \\
\hline 5 mi of Site Boundary & $\sim 29,500$ & $>1600 \mathrm{MWe}$ & $\sim 0.1 \mathrm{mi}$ \\
\hline 10 mi of Site Boundary & $\sim 29,500$ & $>3200 \mathrm{MWe}$ & $\sim 0.1 \mathrm{mi}$ \\
\hline Nearest City with Population & Distance to Cooling Water \\
\hline$>10,000$ & Aiken, SC & $>50,000 \mathrm{gpm}$ & $\sim 0.1 \mathrm{mi}$ (Savannah River) \\
\hline$>50,000$ & North Charleston, SC & $>100,000$ gpm & $\sim 0.1 \mathrm{mi}$ (Savannah River) \\
\hline$>100,000$ & Augusta, GA & $>200,000$ gpm & $\sim 0.1 \mathrm{mi}$ (Savannah River) \\
\hline$>500,000$ & Charlotte, NC & $>500,000$ gpm & $\sim 0.1 \mathrm{mi}$ (Savannah River) \\
\hline Geotechnical & & Accessibility & \\
\hline Max Earthquake Acceleration & $<0.3 \mathrm{~g}$ & Distance to Major Roadway & $\sim 0.1 \mathrm{mi}$ (US-278) \\
\hline Max Slope & $\sim 14 \%$ & Distance to Water Transport & $\sim 0.1 \mathrm{mi}$ (Savannah River) \\
\hline Nearest Fault Line & $\sim 900 \mathrm{mi}$ (Oklahoma) & Distance to Rail Transport & $\sim 0.1 \mathrm{mi}$ (USG) \\
\hline Nearest Hazard Site & $\sim 11$ mi (Airport -Augusta & Distance to Airport & $\sim 11$ mi (Augusta Regional \\
\hline
\end{tabular}

\section{B.5.3 Aerial Imagery}

The aerial imagery in Fig. B.14 indicates clusters of facilities spread across the SRS site. The Vogtle nuclear power plant is visible across the Savannah River from the site in the southwest corner of the image. 


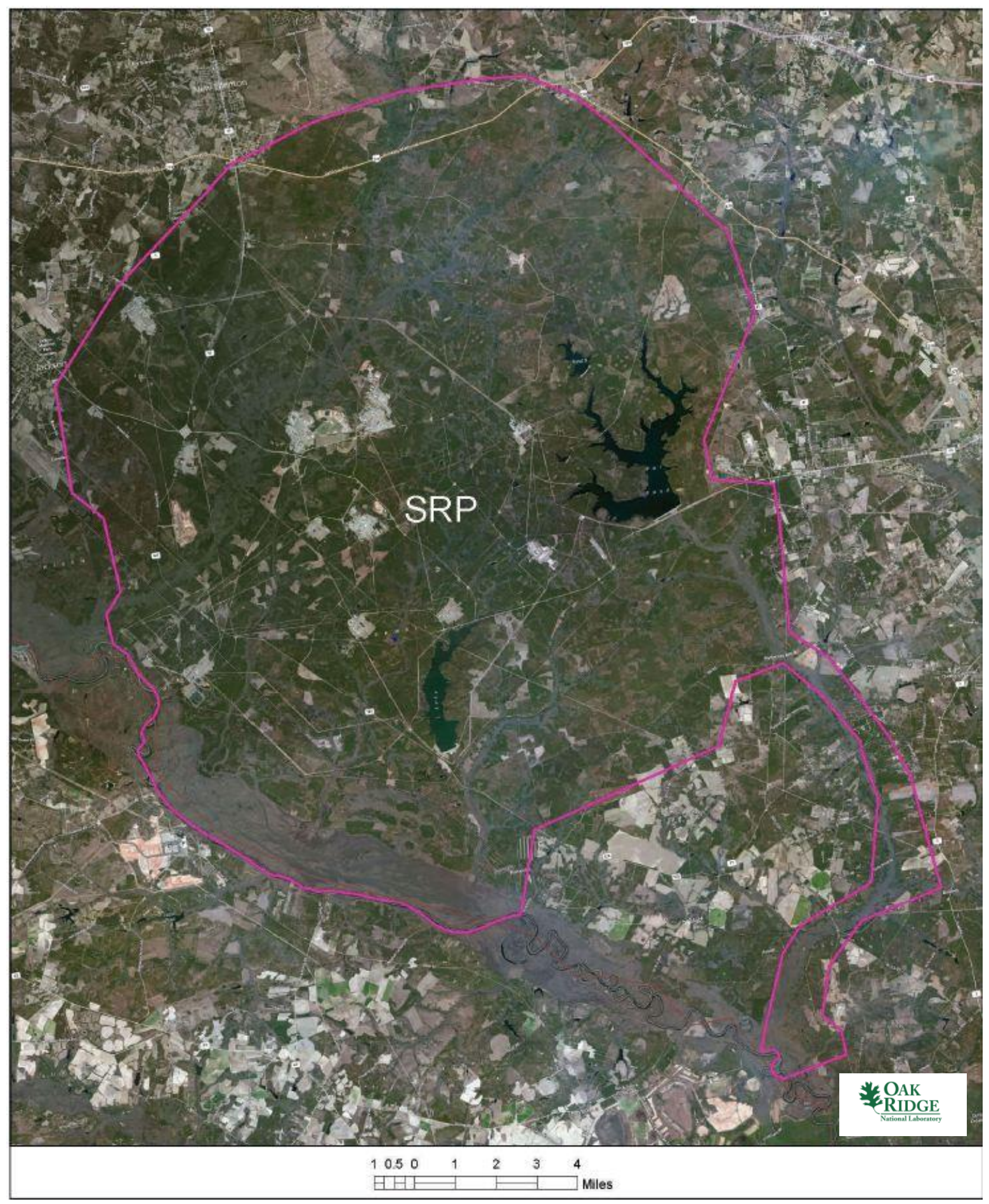

Fig. B.14. Satellite view of Savannah River site area.

\section{B.5.4 Screening Criteria Overview}

Table B.10 shows a screening criteria summary bar, or "dashboard" chart, for the site area provides a quick look at what siting issues may exist for the site. The criteria that are not met within the site area indicated. 
Table B.10. Savannah River site siting criteria summary

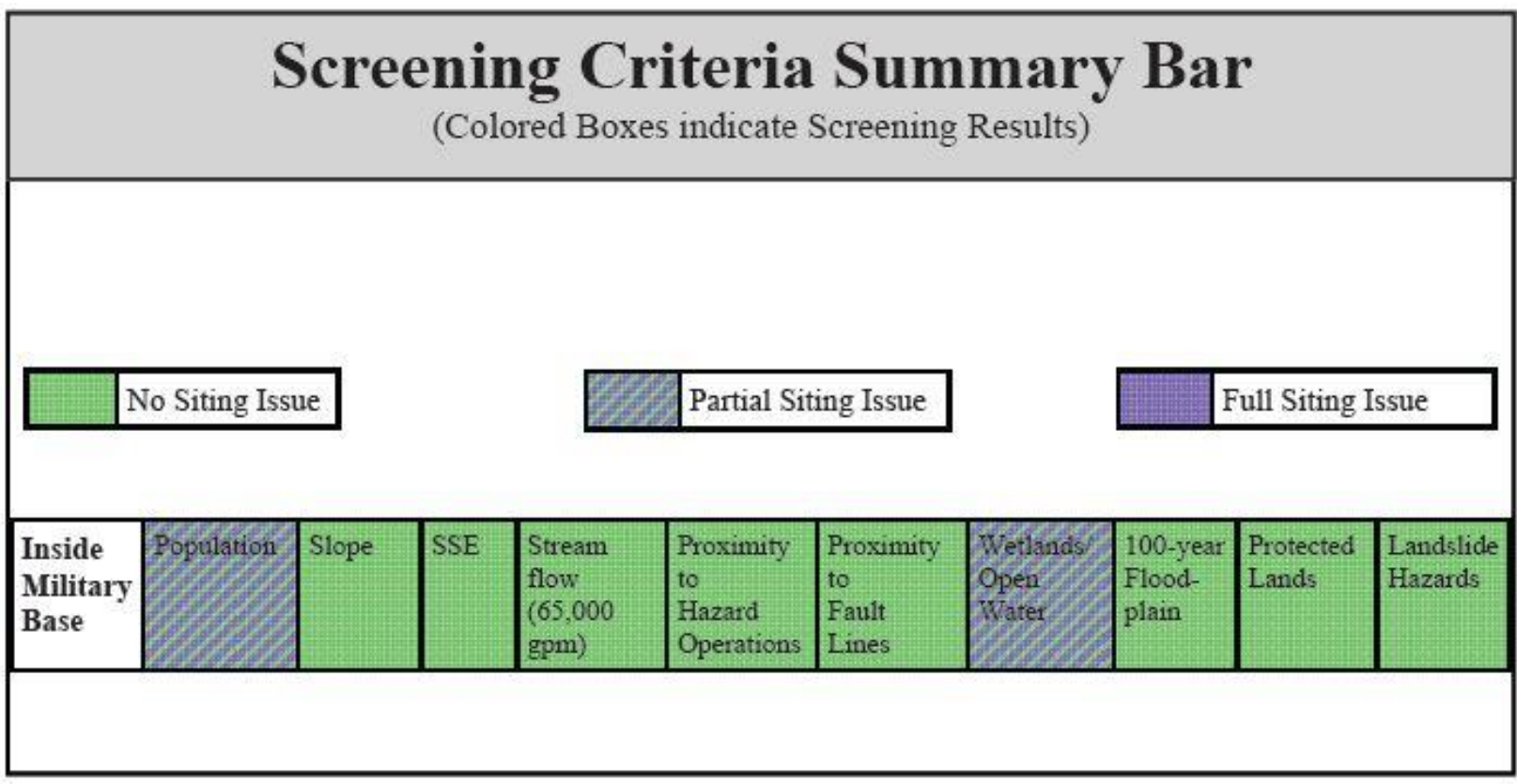

\begin{tabular}{|l|l|}
\hline \multicolumn{2}{|c|}{ Screening Criteria Table } \\
\hline \multicolumn{1}{|c|}{ Criteria } & Value \\
\hline Population Density within 10 miles (people/square mile) & $>500$ \\
\hline Slope & $>18 \%$ \\
\hline Safe shutdown earthquake (ground acceleration) & $>0.5$ \\
\hline Streamflow/cooling water make-up (gpm) & $<65,000$ \\
\hline Proximity to hazardous operations - buffer (mile) & Depends on hazardous operation ${ }^{1}$ \\
\hline Proximity to fault lines - buffer (mile) & Depends on length of fault \\
\hline Wetlands/Open Water & - \\
\hline 100-year floodplain & - \\
\hline Protected lands & - \\
\hline Landslide hazard (moderate and high) & - \\
\hline
\end{tabular}

${ }^{1}$ Hazardous facilities (airports-5 miles and oil refineries-1 mile) 


\section{B.5.5 Composite Map and Individual Siting Issue Maps}

A composite map of SMR siting challenges to the Savannah River Site is shown in Fig. B.15. Siting challenges are predominantly associated with wetlands or open waters across the site. Following this map are maps of the individual SMR siting criteria based on selected input values.

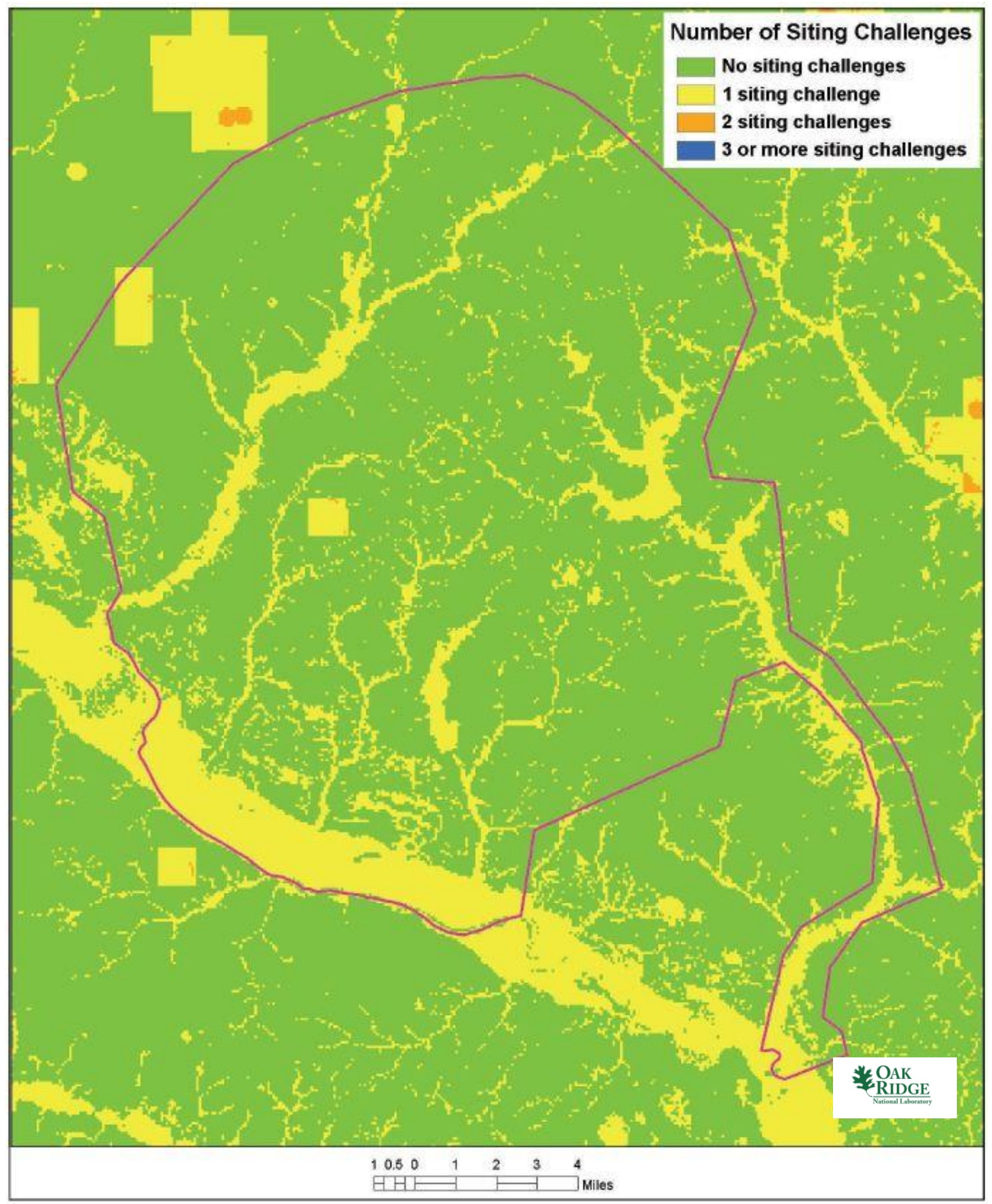

Fig. B.15. Savannah River site composite map. 

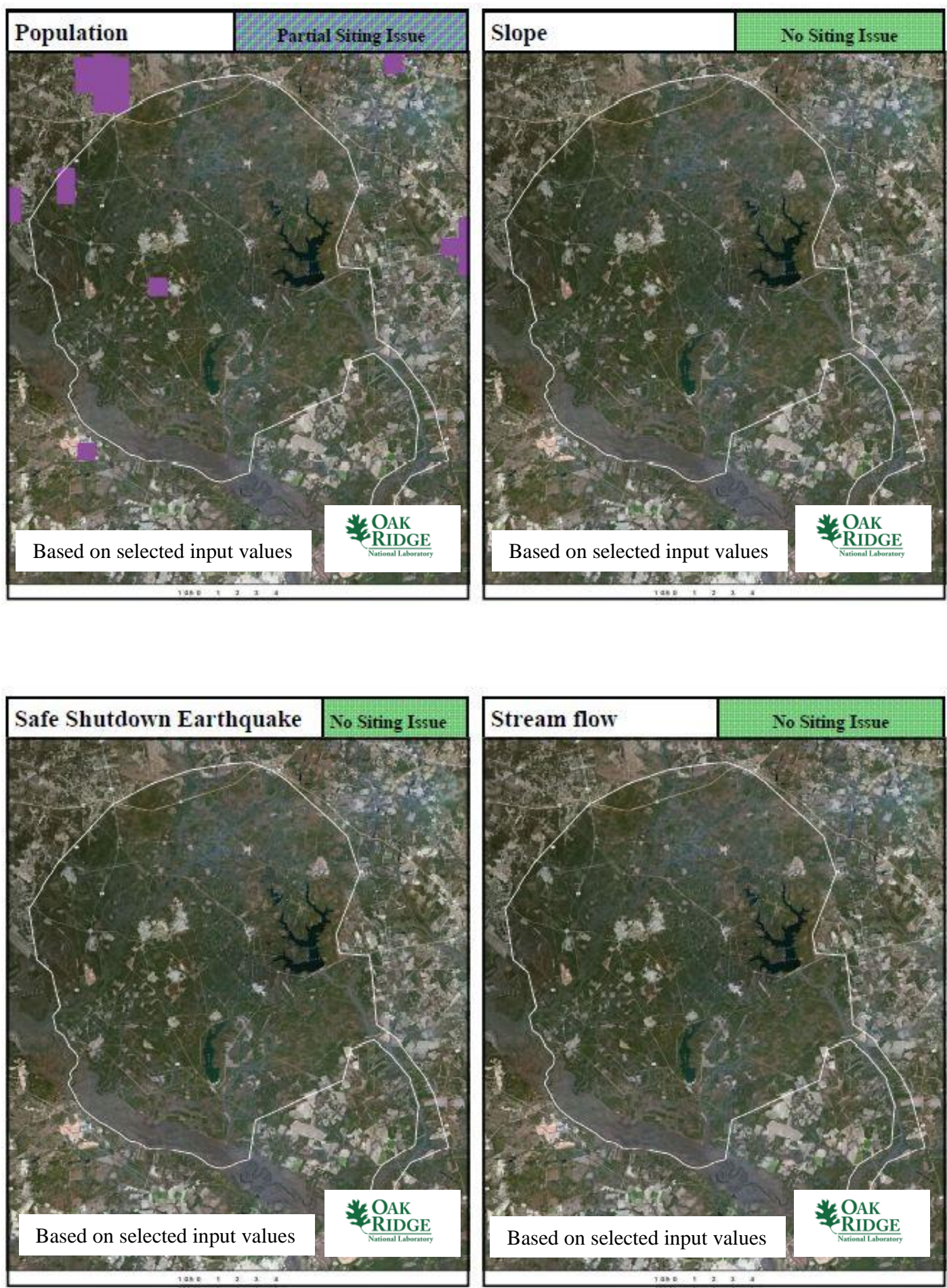

Savannah River Site 

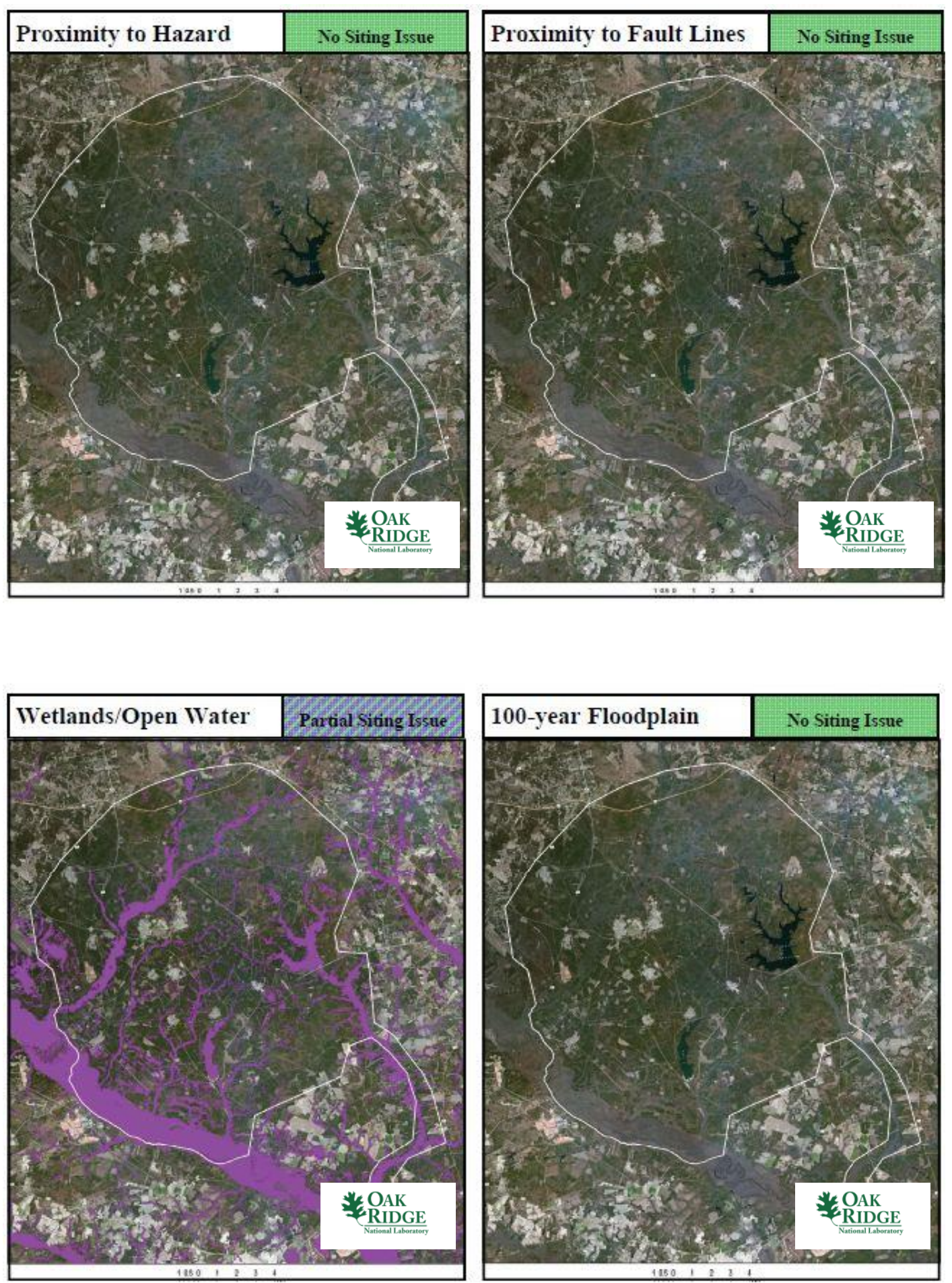

Savannah River Site 

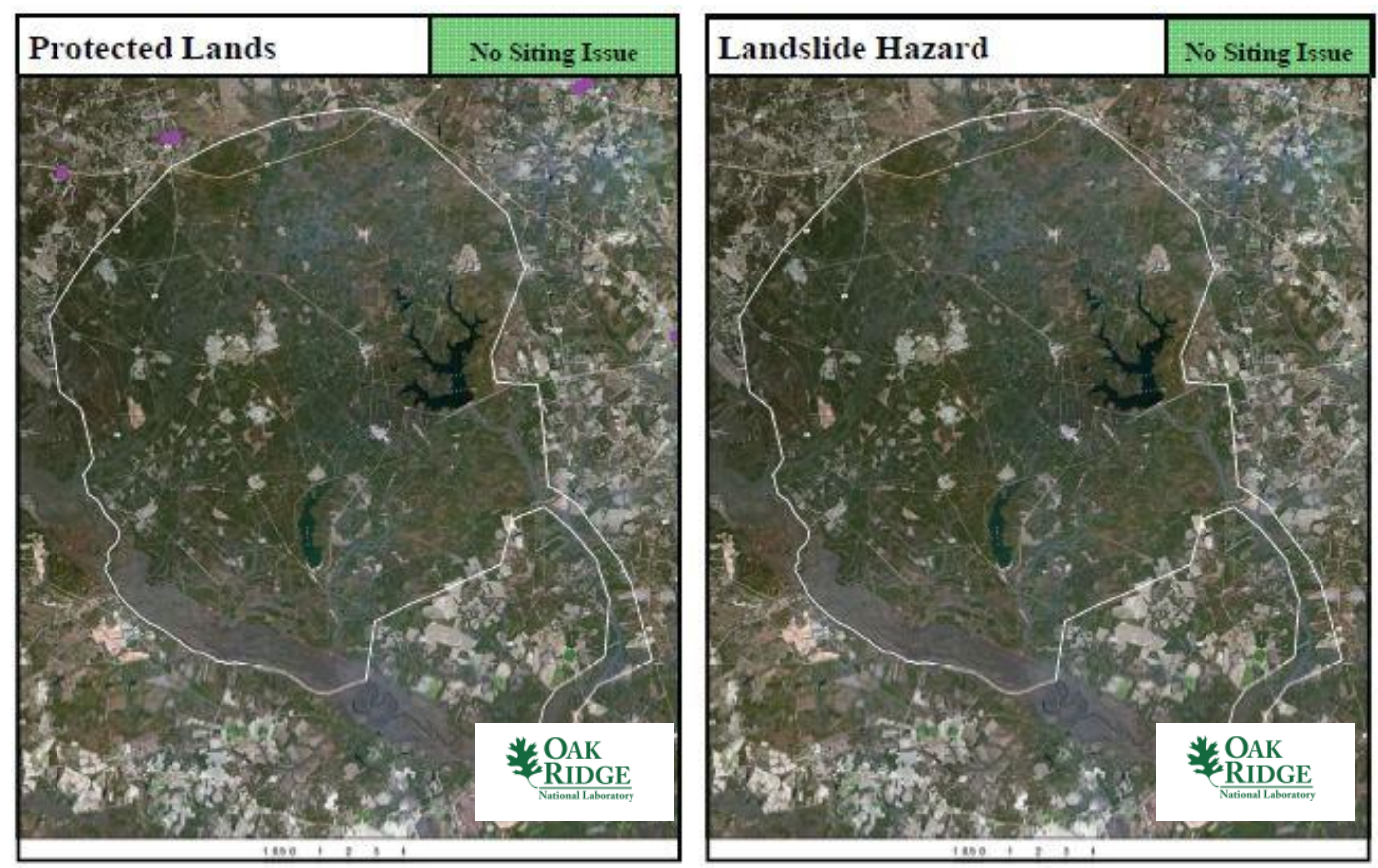

Savannah River Site

\section{B.5.6 Site Evaluation}

The SRS is a large, federally controlled site. A well-trained, well-armed security force is available. Many of the activities and missions carried out on this site are or have been nuclear-related. Personnel have considerable familiarity with the technology- and security-related operations associated with nuclear power plant operation. Power demands on the site associated with the various site missions would also be considerable and feasible for a site-located SMR. Additionally, a vision for the site is a small modular reactor farm. ${ }^{56}$

As shown in Sects. B.5.4 and B.5.5, the SRS has a partial site issue with wetlands/open waters. ${ }^{1}$ This affects areas throughout the site. Approximately $80 \%$ of the 200,000 -acre site meets multiple conventional standards for consideration of siting an SMR on the DOE facility. Note, however, that the composite map does not reflect specific hazards associated with the site that could render some areas as unsuitable for siting a reactor.

The site meets current NRC RG 4.7 recommendations for population density without additional consideration for relaxed SMR population siting requirements based on reduced source term. This site should be classified as favorable for siting an SMR.

\footnotetext{
${ }^{56} \mathrm{http} / / /$ www.srs.gov/general/pubs/e-srs_brochure.pdf
} 